Portland State University

PDXScholar

TREC Final Reports

Transportation Research and Education Center

(TREC)

$6-2012$

\title{
Seismic Hazard Assessment of Oregon Highway Truck Routes
}

Peter Dusicka

Portland State University

Selamawit Tesfayesus Mehary

Portland State University

Follow this and additional works at: https://pdxscholar.library.pdx.edu/trec_reports

Part of the Civil Engineering Commons, Structural Engineering Commons, and the Transportation Engineering Commons

Let us know how access to this document benefits you.

\section{Recommended Citation}

Dusicka, Peter and Selamawit Tesfayesus Mehary. Seismic Hazard Assessment of Oregon Highway Truck Routes. OTREC-RR-11-22. Portland, OR: Transportation Research and Education Center (TREC), 2012. https://doi.org/10.15760/trec.55

This Report is brought to you for free and open access. It has been accepted for inclusion in TREC Final Reports by an authorized administrator of PDXScholar. Please contact us if we can make this document more accessible: pdxscholar@pdx.edu. 


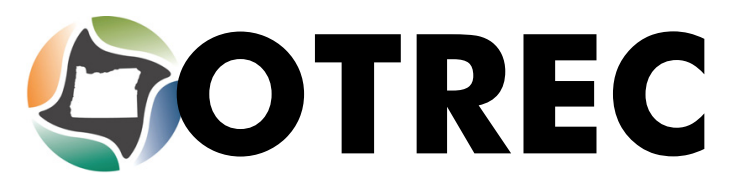

\section{FINAL REPORT}

\section{Seismic Hazard Assessment of Oregon Highway Truck Routes}

OTREC-RR-11-22

June 2012 



\title{
SEISMIC HAZARD ASSESSMENT OF OREGON HIGHWAY TRUCK ROUTES
}

\author{
Report \\ OTREC-RR-11-22 \\ by \\ Selamawit Tesfayesus Mehary \\ Peter Dusicka \\ Portland State University \\ for \\ Oregon Transportation Research \\ and Education Consortium (OTREC) \\ P.O. Box 751 \\ Portland, OR 97207

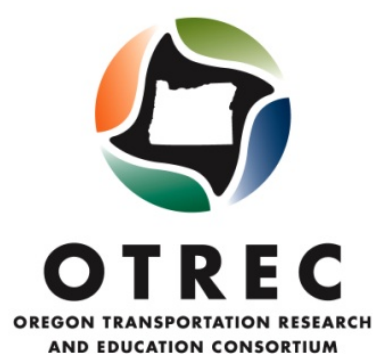

June 2012 



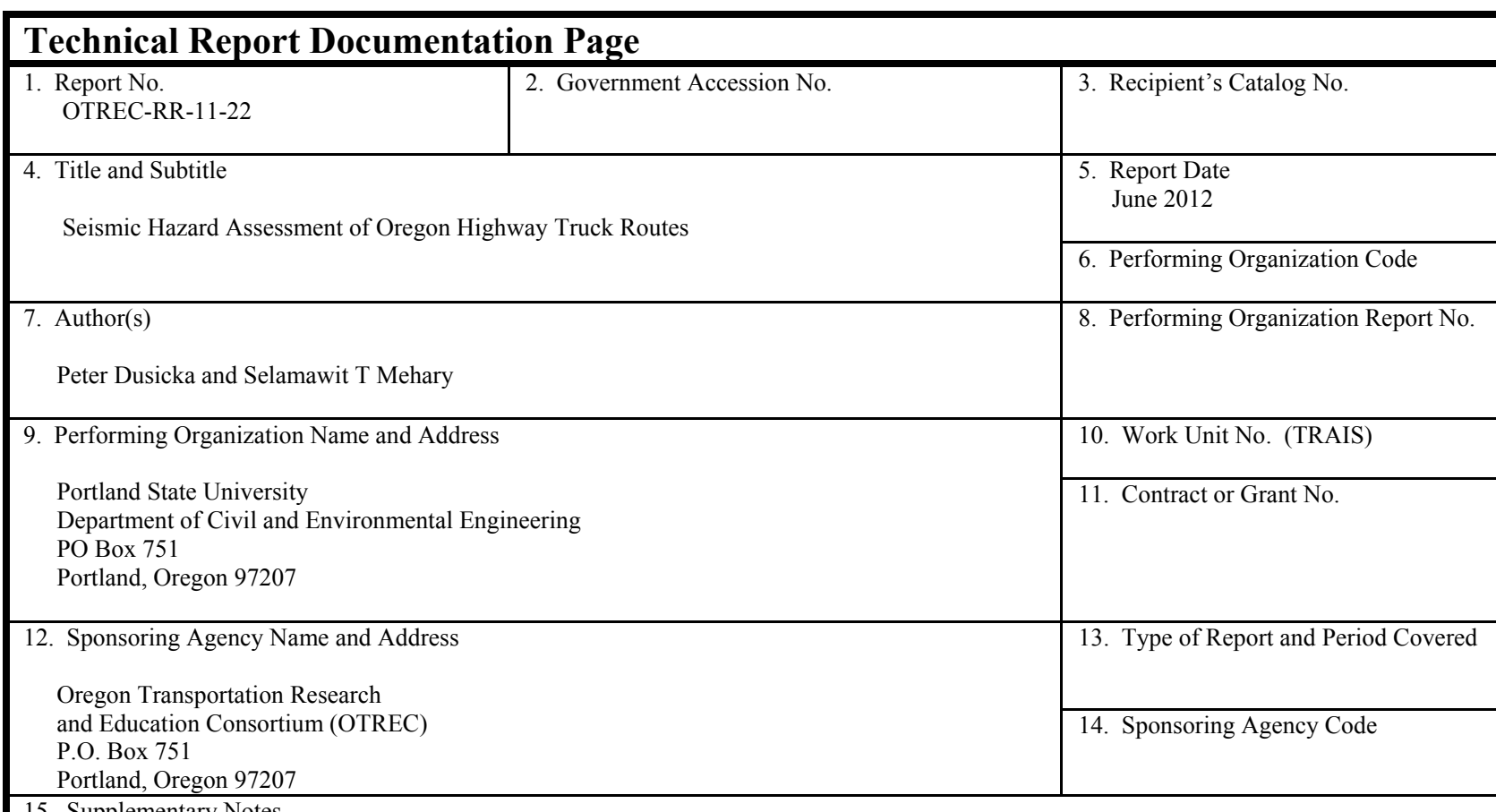

15. Supplementary Notes

\section{Abstract}

This research project developed a seismic risk assessment model along the major truck routes in Oregon. The study had adopted federally developed software tools called Risk for Earthquake Damage to Roadway Systems (REDARS2) and HAZUS-MH. The model was the first time REDARS2 has been adopted and used in research outside of the original development team, presenting a number of unique challenges. The development of the model was a complex, intensive process that required a significant research effort, manipulation and adjustment of data. Furthermore, limitations of the software tools themselves had been identified that prevented the inclusion of important aspects such as liquefaction induced damage and refinement of the transportation network.

The main objective of this research were to refine the data from a first generation of the model to more realistically represent the bridge inventory, to address the seismicity of the Pacific Northwest, conduct sensitivity analyses of soil data on the analyses results and develop a seismic network model of Oregon bridges for purposes of assessing the seismic vulnerability of roadway segments.

The first generation model relied on default settings within the program to determine the economic loss due to repair and replacement of damaged bridges. The assumptions used in the analyses have been reviewed and Oregon specific data was incorporated for the model. The largest earthquake now considered to be at a highest level of probability in the Pacific Northwest is a subduction zone earthquake. The major shortcoming of REDARS2 is its inability to incorporate the subduction zone attenuation relationship into the analysis. To incorporate that capability into the model, shakemaps were developed by USGS for Cascadia subduction zone scenario events and incorporated as the demand on the refined model.

Analyses of the transportation network incorporating bridge routes and post processing of the data with input from Oregon DOT bridge engineers resulted in recommendations toward bridge route priority strategies. The majority of the bridges that indicated the possibility of damage were types associated with multi-column bents, simply-supported concrete superstructures and simply-supported steel superstructures. Of the major highway routes that were considered, I-405, section of I-5 (from Multnomah to Clackamas Counties), I-84, I-205 and US-101 were the top five on the preliminary priority for seismic retrofit. These routes need to be analyzed more and advanced cost-benefit investigations should be done before retrofit decisions are made.

\begin{tabular}{|l|l}
\hline 17. Key Words & $\begin{array}{l}\text { 18. Distribution Statement } \\
\text { No restrictions. Copies available from OTREC: } \\
\text { www.otrec.us }\end{array}$ \\
\end{tabular}

19. Security Classification (of this report)

Unclassified 20. Security Classification (of this page)

Unclassified

\author{
21. No. of Pages \\ 110
}




\section{ACKNOWLEDGEMENTS}

This project was funded by the Oregon Transportation Research and Education Consortium (OTREC) and Oregon Department of Transportation (ODOT). Various assistance from other contributors at PSU Department of Civil Engineering, School of Urban Planning, Federal Highway Administration (FHWA), ImageCat Inc. and the REDARS2 Group. The authors would like to thank everyone who contributed their time and effort to help complete this phase of the research.

\section{DISCLAIMER}

The contents of this report reflect the views of the authors, who are solely responsible for the facts and the accuracy of the material and information presented herein. This document is disseminated under the sponsorship of the U.S. Department of Transportation University Transportation Centers Program in the interest of information exchange. The U.S. Government assumes no liability for the contents or use thereof. The contents do not necessarily reflect the official views of the U.S. Government. This report does not constitute a standard, specification or regulation. 


\section{TABLE OF CONTENTS}

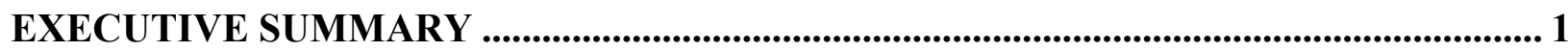

1.0 INTRODUCTION AND PROJECT DESCRIPTION ................................................. 3

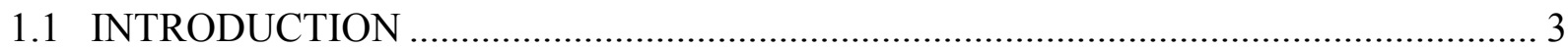

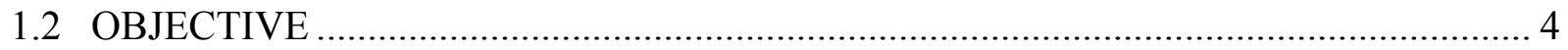

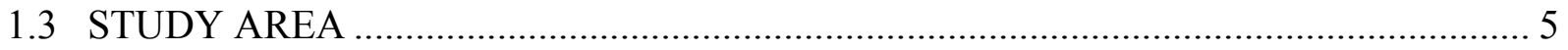

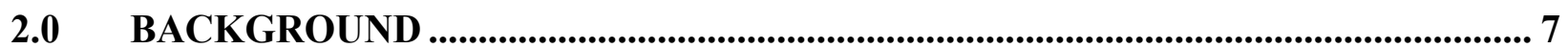

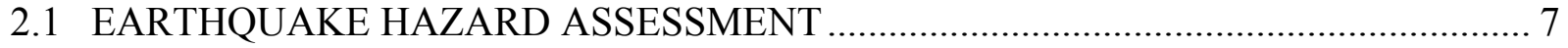

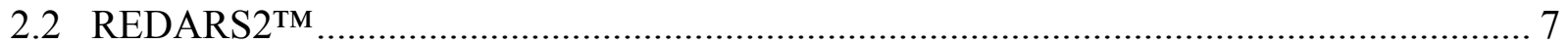

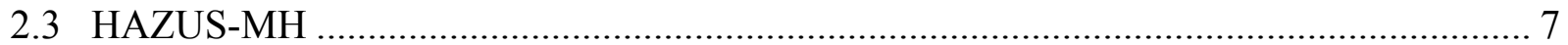

2.4 PREVIOUS RESEARCH ON SEISMIC VULNERABILITY ASSESSMENTS............. 8

2.5 APPLICATION AND FUTURE USE OF OREGON REDARS2 MODEL................... 9

2.6 BRIDGES CONSIDERED IN THE ASSESSMENT ................................................ 9

3.0 REFINEMENT OF OREGON REDARS2 HIGHWAY NETWORK MODEL....... 13

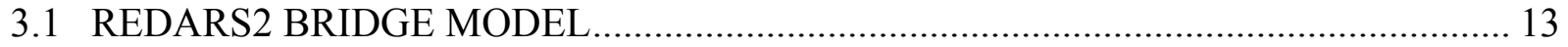

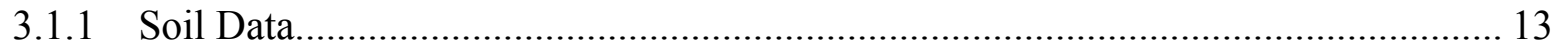

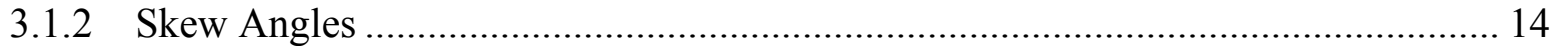

3.1.3 Replacement and Repair Cost ......................................................................... 14

3.2 ROADWAY TRANSPORTATION NETWORK DATABASES AND

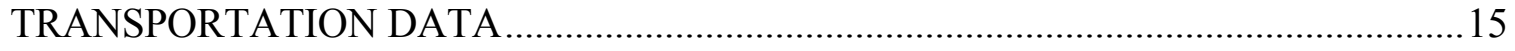

4.0 GEOTECHNICAL ASSESSMENT ............................................................................... 19

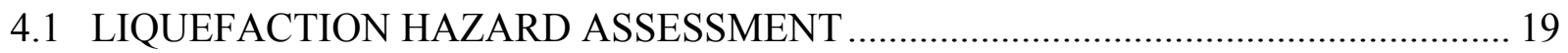

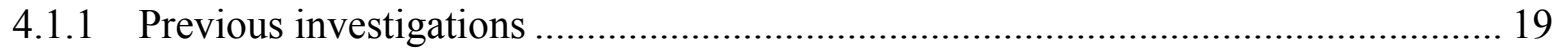

4.1.2 Liquefaction Assessment in REDARS2 …........................................................ 19

4.1.3 Liquefaction Potential Assessment Independent of REDARS2 .......................... 22

4.1.4 Methodology and Analysis .................................................................... 23

4.1.5 Results of Liquefaction Potential Assessment .................................................... 23

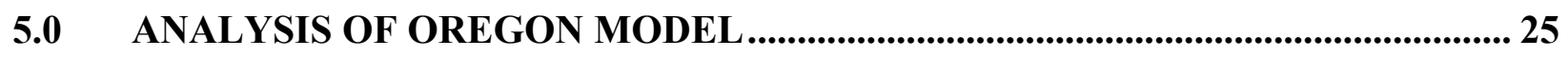

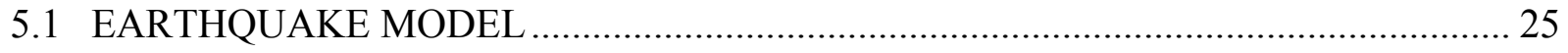

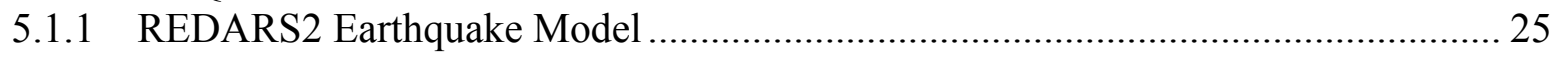

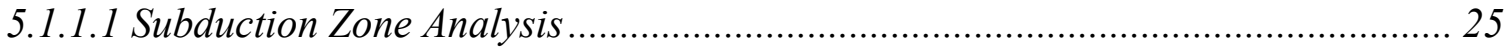

5.1.2 HAZUS-MH Earthquake Model ..................................................................... 28

5.2 COMPONENT DAMAGE ANALYSIS ............................................................... 28

5.2.1 Bridge Damage State model ............................................................................ 28

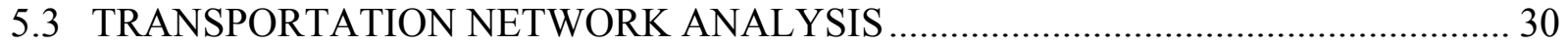

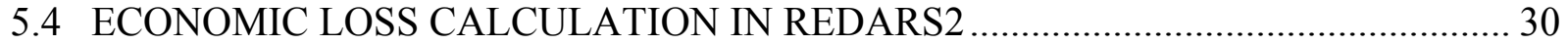

5.4.1 Repair Cost............................................................................................. 30

5.4.2 Losses due to Travel-Time Delays and Trips Foregone ....................................... 31

5.5 COMPARISON OF DAMAGE STATE ANALYSIS METHODS ............................ 32

6.0 EARTHQUAKE SCENARIOS USED IN ANALYSIS ...................................... 35

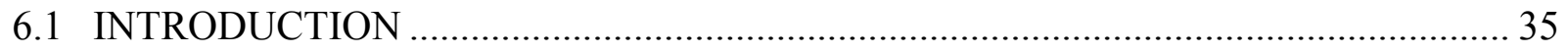

6.1.1 Crustal Earthquake Scenarios in the Portland Metro Area .................................. 35

6.1.2 Crustal Earthquake Scenarios in the Scotts Mills ................................................ 36 
6.1.3 Crustal Earthquake Scenarios in the Klamath Falls.......................................... 36

6.1.4 Full Length Cascadia Subduction Zone Earthquake.......................................... 37

6.1.5 Cascadia Subduction Zone Earthquake near Northern Oregon ............................... 38

6.1.6 Cascadia Subduction Zone Earthquake near Southern Oregon ............................... 39

6.1.7 Summary of number of damaged bridges per route.......................................... 41

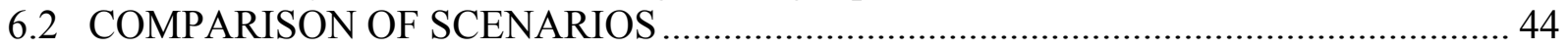

7.0 SENSITIVITY ANALYSIS ................................................................................. 45

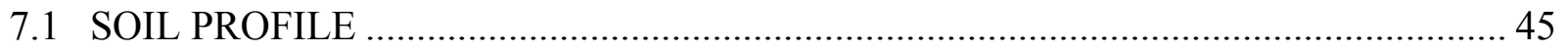

7.1.1 Liquefaction Settlement Trigger of Damage State ............................................ 45

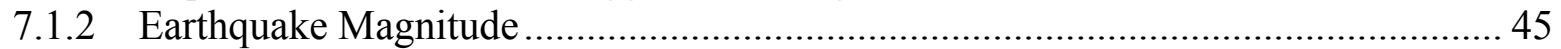

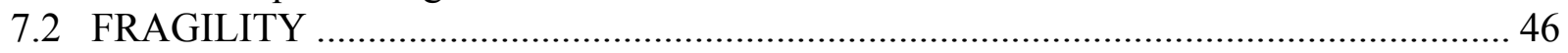

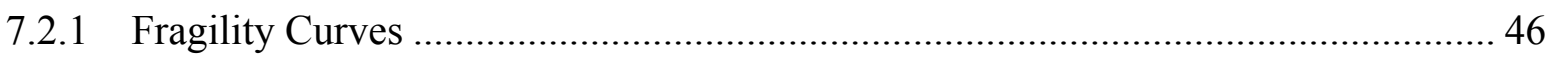

8.0 VULNERABILITY OF EXISTING NETWORK AND RECOMMENDATION

FOR BRIDGE RETROFIT ...............................................................................................5 53

8.1 VULNERABILITY OF OREGON HIGHWAY NETWORK ..................................... 53

8.2 ADVANTAGES OF RETROFITTING ............................................................ 55

9.0 CONCLUDING REMARKS ............................................................................... 57

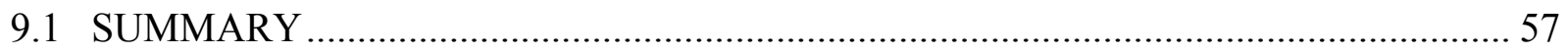

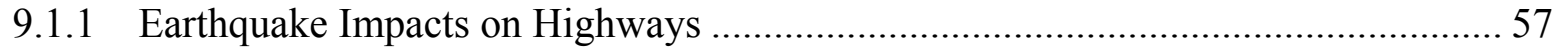

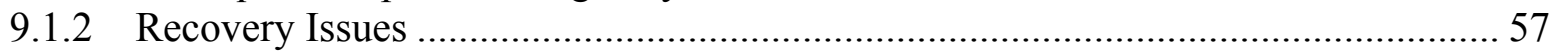

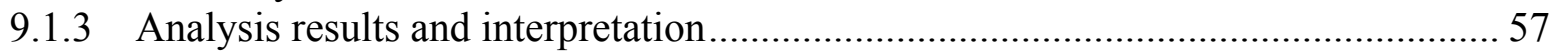

9.2 SUMMARY OF ISSUES ENCOUNTERED IN REDARS2 .................................. 58

9.3 SUGGESTION FOR FUTURE RESEARCH ...................................................... 58

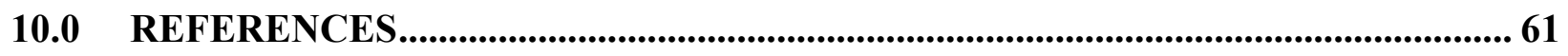

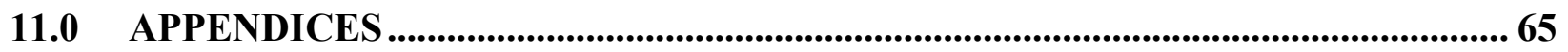

11.1 APPENDIX A - HIGHWAY SYSTEM CLASSIFICATION ...................................... 65

11.2 APPENDIX B - DAMAGE ALGORITHMS AND FRAGILITY CURVES FOR

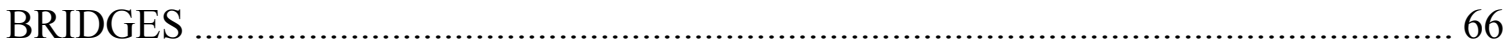

11.3 APPENDIX C - SCENARIO RESULTS BY HIGHWAY ROUTE AND BRIDGE TYPE 78

11.4 APPENDIX D - BRIDGE CLASSIFICATION BY MATERIAL AND DESIGN PER

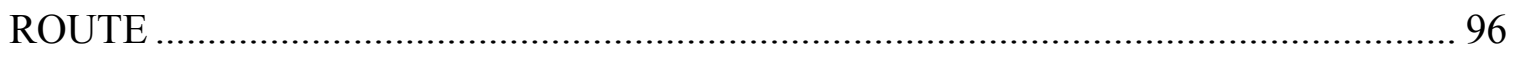

11.5 APPENDIX E - SKEW ANGLE INCONSISTENCY ............................................... 98 


\section{LIST OF TABLES}

Table 1: Construction Materials Listed in NBI (FHWA, 1995a). ........................................... 10

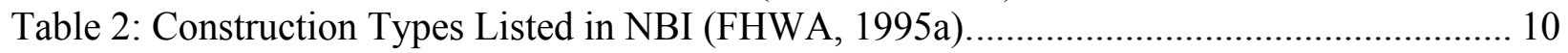

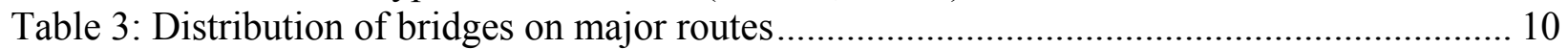

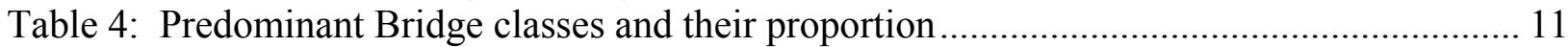

Table 5: Bridge Types and number of spans ................................................................ 11

Table 6: Average Repair Cost Estimate............................................................................. 15

Table 7: Damage States considered in REDARS2 Bridge Model .............................................. 29

Table 8: Default Traffic States during Repair of Bridge Damage from Ground Motions (Werner

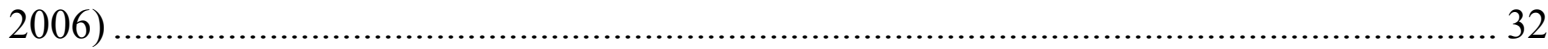

Table 9: Portland Hills M6.5 Scenario Analysis Results....................................................... 41

Table 10: Scotts Mills M7.0 Scenario Analysis Results........................................................ 41

Table 11: Klamath Falls M7.0 Scenario Analysis Results ................................................... 42

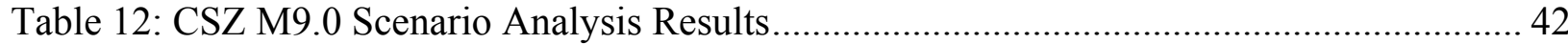

Table 13: CSZ North M8.3 Scenario Analysis Results ......................................................... 43

Table 14: CSZ South M8.3 Scenario Analysis Results ......................................................... 43

Table 15: Cascadia Subduction zone scenario event M9.0.................................................... 48

Table 16: Cascadia Subduction zone scenario event- North M8.3 .......................................... 49

Table 17: Cascadia Subduction zone scenario event- South M8.3 ......................................... 50

Table 18: Portland Hills scenario event- South M6.5 …...................................................... 51

Table 19: Replacement cost of state highway bridges on selected routes in millions................. 54

Table 20: Preliminary Route Seismic Retrofit Prioritization Ranking..................................... 56 


\section{LIST OF FIGURES}

Figure 1: Map of Oregon Department of Transportation State Routes (ODOT 2006)................... 4

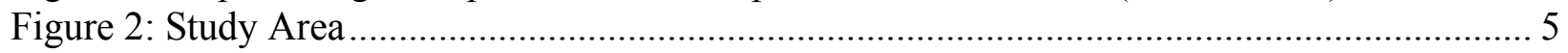

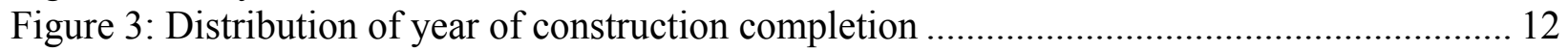

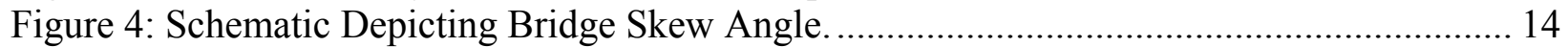

Figure 5: Old FHWA National Highway Planning Network.......................................................... 17

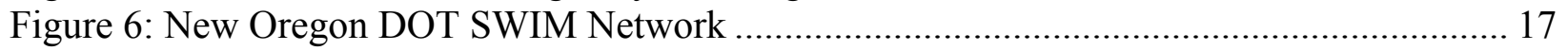

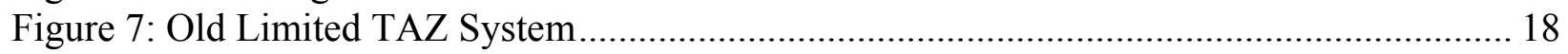

Figure 8: Comprehensive TAZ System .......................................................................... 18

Figure 9: Liquefaction-Induced Volumetric Strains for Each Saturated Sand Layer in Site

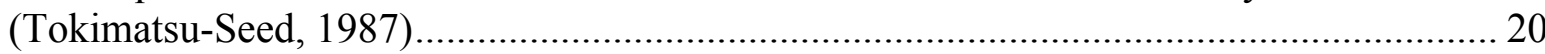

Figure 10: Liquefaction induced damages on bridges for a scenario earthquake at Scotts Mills

(M7.0) ............................................................................................................... 21

Figure 11: Liquefaction induced damages on bridges for a scenario earthquake at Scotts Mills

(M5.6) ....................................................................................................... 22

Figure 12: Vertical Settlement vs. (N1)60 for different thickness (T) of layers at PGA $\geq 0.00045$

Figure 13: Initial Liquefaction probability screening of bridges.................................................. 23

Figure 14: Seismic Risk Analysis of Roadway Systems …………………………………..... 26

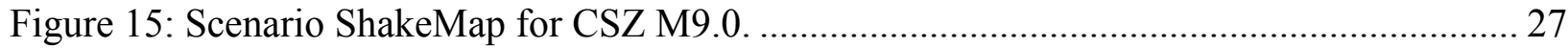

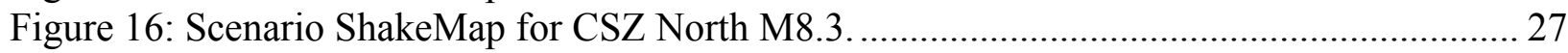

Figure 17: Scenario ShakeMap for CSZ South M8.3 …….................................................. 28

Figure 18: Component Damage States for a Magnitude 6.5 Scenario Earthquake around Portland Hills 36

Figure 19: Component damage States for Magnitude 7.0 Scenario Earthquake around Scotts

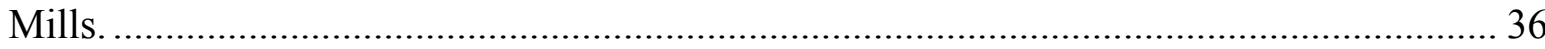

Figure 20: Component Damage States for Magnitude 7.0 Scenario Earthquake around Klamath

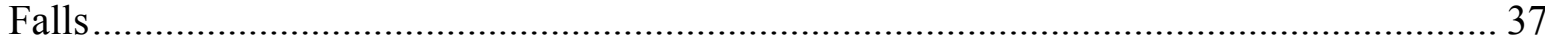

Figure 21: Component Damage States for a M9.0 Cascadia Subduction Zone Scenario

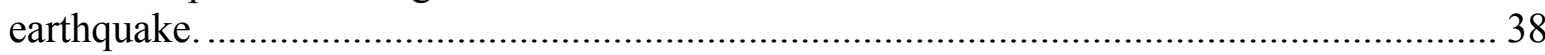

Figure 22: Component Damage States for a Magnitude 8.3 Cascadia Subduction Zone Scenario

Earthquake near northern Oregon ................................................................................. 39

Figure 23: Component Damage States for a Magnitude 8.3 Cascadia Subduction Zone Scenario

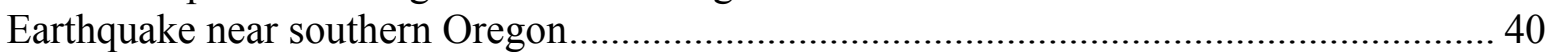

Figure 24: Site Classification Sensitivity on Earthquake magnitude........................................... 46

Figure 25: Fragility curve comparison of HWB4 and HWB5 …………................................... 47

Figure 26: Aggregated fragility curve for I-40 crossing of Mississippi River. ............................ 47 


\section{EXECUTIVE SUMMARY}

This research project developed a seismic risk assessment model along the major truck routes in Oregon. The study had adopted federally developed software tools called Risk for Earthquake Damage to Roadway Systems (REDARS2) and HAZUS-MH. The model was the first time REDARS2 has been adopted and used in research outside of the original development team, presenting a number of unique challenges. The development of the model was a complex, intensive process that required a significant research effort, manipulation and adjustment of data. Furthermore, limitations of the software tools themselves had been identified that prevented the inclusion of important aspects such as liquefaction induced damage and refinement of the transportation network.

The main objective of this research were to refine the data from a first generation of the model to more realistically represent the bridge inventory, to address the seismicity of the Pacific Northwest, conduct sensitivity analyses of soil data on the analyses results and develop a seismic network model of Oregon bridges for purposes of assessing the seismic vulnerability of roadway segments.

The first generation model relied on default settings within the program to determine the economic loss due to repair and replacement of damaged bridges. The assumptions used in the analyses have been reviewed and Oregon specific data was incorporated for the model. The largest earthquake now considered to be at a highest level of probability in the Pacific Northwest is a subduction zone earthquake. The major shortcoming of REDARS2 is its inability to incorporate the subduction zone attenuation relationship into the analysis. To incorporate that capability into the model, shakemaps were developed by USGS for Cascadia subduction zone scenario events and incorporated as the demand on the refined model.

Analyses of the transportation network incorporating bridge routes and post processing of the data with input from Oregon DOT bridge engineers resulted in recommendations toward bridge route priority strategies. The majority of the bridges that indicated the possibility of damage were types associated with multi-column bents, simply-supported concrete superstructures and simplysupported steel superstructures. Of the major highway routes that were considered, I-405, section of I-5 (from Multnomah to Clackamas Counties), I-84, I-205 and US-101 were the top five on the preliminary priority for seismic retrofit. These routes need to be analyzed more and advanced cost-benefit investigations should be done before retrofit decisions are made. 


\subsection{INTRODUCTION AND PROJECT DESCRIPTION}

\subsection{INTRODUCTION}

Geologists have indicated that the question is not if a catastrophic earthquake will occur in Oregon, but when one will occur. Seismologists have long known about the potential earthquake threat in the Pacific Northwest stretching from northern Vancouver Island in Canada to northern California which is the Cascadia subduction zone, where one giant plate of the Earth's surface is diving deep beneath another one.

The effects of an earthquake of this magnitude can result in potential sudden detrimental impact on the transportation infrastructure where bridges represent vulnerability points within the network. When bridge damage occurs during a seismic event, short-term or long-term interruptions to traffic flow result. This will delay emergency response in the hours after the event, and restrict the movement of people and goods for months. Hence, the economic impact of bridge damage includes not only the cost of structural repair, but also longer term consequences relating to valued loss of time when commuter and freight travel slows down to navigate the disrupted network.

Hundreds of bridges in the State of Oregon are still vulnerable to earthquake damage. Over the last decade it has been shown during the course of bridge inspections that many of the bridges are showing signs of deterioration. As reported by Patrick Brennan for the Oregon Legislative Committee Services council in a brief, the causes of this deterioration problem include older construction methods, structures beyond their intended construction life, and a scale of increased use that was not accounted for in the original design of the bridges. Currently, the Oregon Department of Transportation (ODOT) owns and maintains just over 2600 bridges distributed over the state controlled routes shown in Figure 1. Of the approximately 2600 bridges, a fifth of them are beyond the 50-year construction life (Brennan 2004).

The risk associated with earthquake hazards on highway systems is largely dependent on the complexity and redundancy of a network in providing smooth traffic flow. Seismic Risk Assessment (RSA) studies can provide decision makers with an appreciation of the importance of having a highway network resistant to earthquakes and information to make the network invulnerable to these events. The main objective of this research project is to address the major limitations for the current state of the model to more appropriately represent the traffic conditions and the seismicity of the Pacific Northwest. This involved refining the transportation network, bridge database and more appropriately studying the region and investigating the sensitivity of key input parameters such as bridge fragility, damage threshold and liquefaction threshold on the global results. The model was then used to analyze the network resulting in recommendations toward bridge retrofit strategies. 


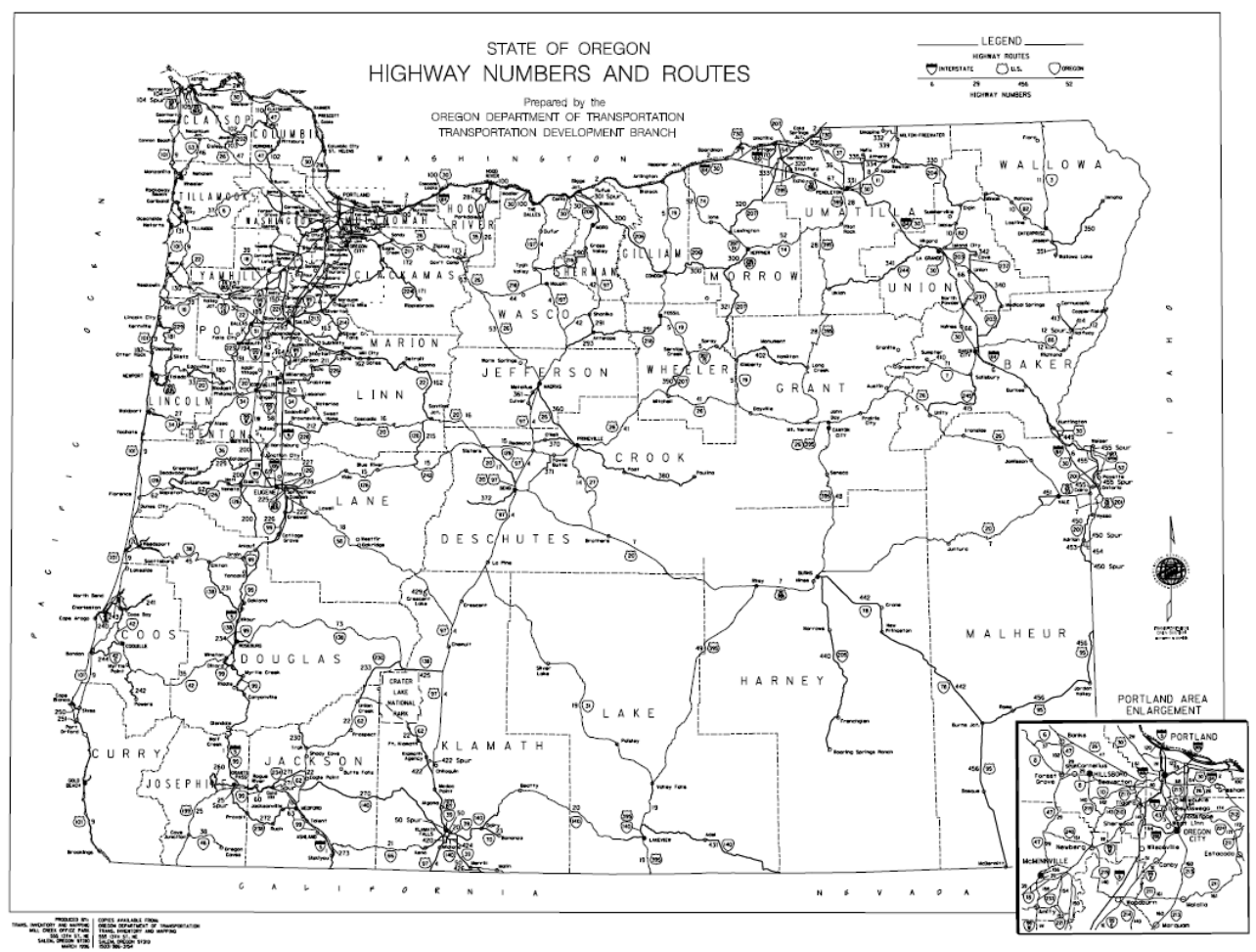

Figure 1: Map of Oregon Department of Transportation State Routes (ODOT 2006)

\subsection{OBJECTIVE}

The primary objective of this research is to develop seismic network model of Oregon bridges for seismic retrofit prioritization, and to assess the seismic vulnerability of roadway components. This project builds up on the already created GIS model of the roadway and bridge network using new technology developed for the Federal Highway Administration called REDARS2 (Risks from Earthquake DAmage to Roadway Systems) by Portland State University (Dusicka 2008). In the previous study, a number of limitations in the existing data as well as the software capabilities itself had been identified to the point that without further research and implementation, the results of the existing model are not realistic.

The objectives of this research are therefore to:

- Implement subduction zone attenuation relationship as part of the analysis capabilities of REDARS2

- Verify analysis results and conduct sensitivity analyses for key input parameters

- Refine the statewide traffic data to more closely reflect current condition

- Assess vulnerability of the existing network and develop recommendations for bridge retrofit.

- Compare REDARS2 vs. HAZUS-MH 


\subsection{STUDY AREA}

The previous study done by PSU of the seismic vulnerability assessment has been on bridges lying on or crossing over Oregon highway routes in the area that included all highway routes lying inside or west of the I-5 corridor, highway routes in the Portland area, the entire length of US-101 and a partial I-84 Columbia River Highway. The bridge data were collected to include bridges up to the year 2008 .

The previous model was further refined to more closely reflect current condition and include subduction zone considerations and also verify analysis results and conduct sensitivity analyses for key input parameters. The next step in model development is to include a more enhanced transportation network beyond highways and include county owned bridges and to encompass the entire state of Oregon (Figure 2).

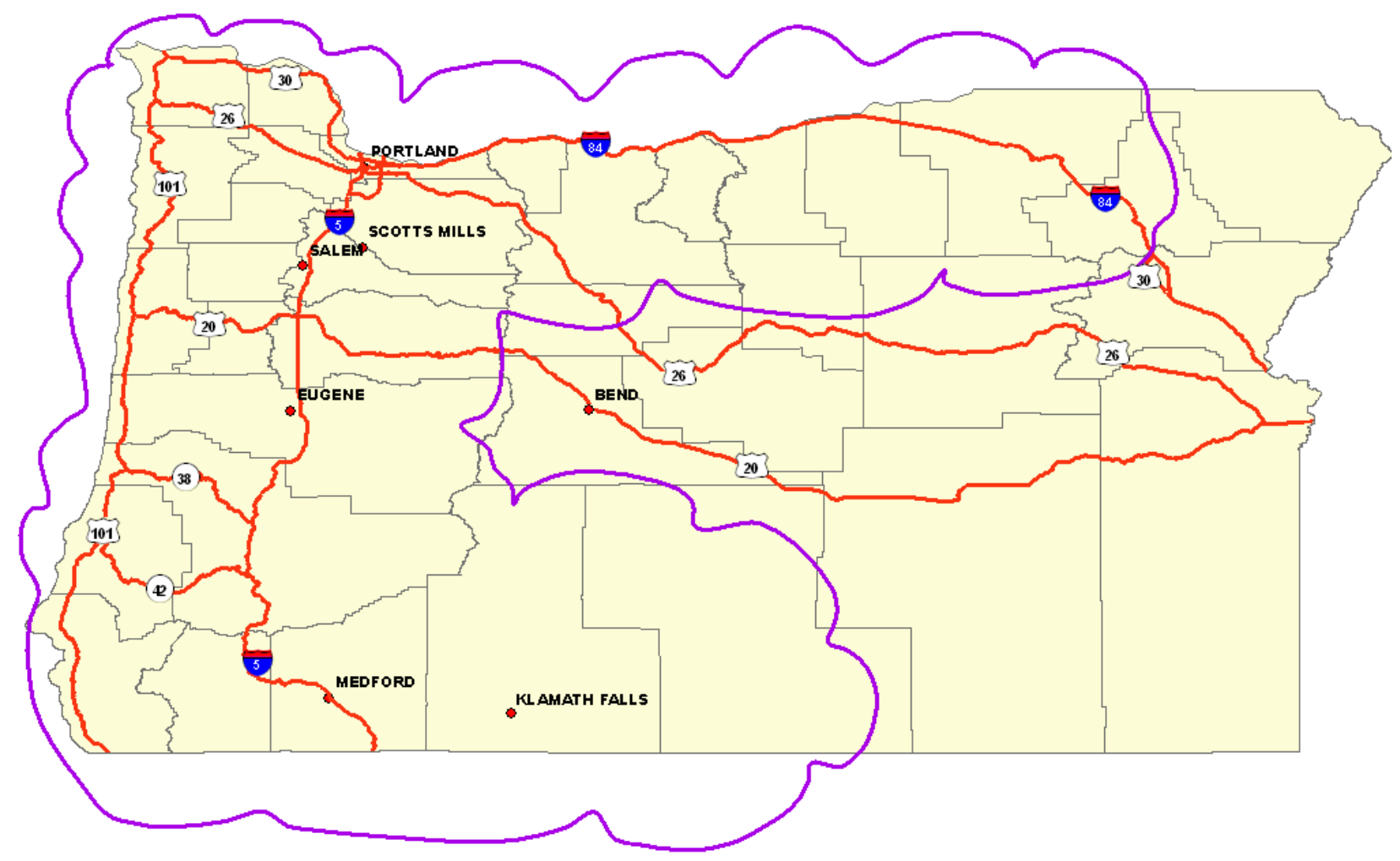

Figure 2: Study Area 


\subsection{BACKGROUND}

\subsection{EARTHQUAKE HAZARD ASSESSMENT}

The earthquake hazard assessment provides local, state and regional officials with a decision support tool for estimating potential losses from scenario earthquakes. Being able to estimate this gives users that capability to anticipate the consequences of future earthquakes and to develop plans and strategies for reducing risk. The Seismic Risk Analysis (SRA) methodology is a synthesis of models developed by earth scientists, geotechnical and structural earthquake engineers, transportation engineers and planners, and economists. The methodology can develop multiple types of results from deterministic or probabilistic approaches and from local to large geographic areas. Such results can be developed for use in pre-earthquake assessment of various options for seismic risk reduction after an actual earthquake. The software products utilized in this study are HAZUS-MH and REDARS2. The results from REDARS2 have been compared to HAZUS-MH to verify REDARS2 analysis results.

\subsection{REDARS2 ${ }^{\mathrm{TM}}$}

REDARS2 2 (Risks from Earthquake DAmage to Roadway Systems) is GIS software that is used to develop deterministic and probabilistic estimates of the seismic performance of highwayroadway systems. The methodology and software was the result of 12 years of development with the financial sponsorship of FHWA. REDARS2 ${ }^{\mathrm{TM}} 2$ uses a default model for estimating bridge damage due to ground motions that corresponds to the HAZUS99-SR2 model (FEMA 2002), which is the earliest version of HAZUS-MH. However, REDAR2 also has the capability to conduct roadway transportation network analysis. Seismic performance of these systems is measured in terms of potential for earthquake-induced disruptions of system-wide travel times and traffic flows, and the economic impacts and other losses due to these disruptions.

\subsection{HAZUS-MH}

HAZUS-MH (Hazards U.S.) is also GIS software used for loss estimation application. GIS technology facilitates the manipulation of data. HAZUS-MH is a methodology that has been developed for the Federal Emergency Management Agency (FEMA) by the National Institute of Building Sciences (NIBS) to provide a tool for developing earthquake loss estimates for use in anticipating the possible nature and scope of the emergency response needed to cope with an earthquake-related disaster, developing plans for recovery and reconstruction following a disaster, and mitigating the possible consequences of earthquakes (FEMA 2003).

Interdependence of components on overall system functionality is not addressed by HAZUS. Such considerations require a network system analysis that would be performed separately by a highway system expert. HAZUS-MH methodology, however, provides a series of combination attenuation relationships including a Subduction Event. 


\subsection{PREVIOUS RESEARCH ON SEISMIC VULNERABILITY ASSESSMENTS}

Seismic Design Decision Analysis (SDDA) is a methodology that was introduced by Whitman et al. in 1975. Most seismic risk assessments (SRA) that are being used have been based on this methodology. SDDA considers the effects of earthquake hazard, damage, and also economic losses. The effects of the damages were studied as probabilities of different damage levels.

The vulnerability of components to earthquake damage depends on the seismic capacity of the component together with the earthquake hazard. King et al. (1997) discuss the advantages of creating generic classes where components can be grouped. This makes it possible to predict, deterministically, the relationships for each class that quantify the damage as a function of the ground shaking.

Earthquake damage to highway components can go well beyond life safety risks and the costs to repair the component itself. When bridge damage occurs during a seismic event, short-term or long-term interruptions to traffic flow result. This can impact post-earthquake emergency response, repair and reconstruction. The level of impact depends on the seismic performance of individual components and the characteristics of the highways system such as network configuration, location, redundancy, traffic capacity and traffic volume (Werner 2006).

Werner and Taylor (2002) emphasized the significance of observing component functionality and location within a lifeline system to assess system performance. Component functionality depends on seismic response characteristics of a component and the state of damage, and also how the damage can be repaired, cost of repair and its significance in the overall system.

Knowing whether a bridge will be fully closed, partially open, or fully open provides a means of analyzing networks as a whole.

One of main end results from SRA of roadway systems is the estimation of economic impacts of earthquake damage to the system. Recent studies done on transportation networks place a strong emphasis on indirect costs due to traffic flow and travel times. Indirect economic loss estimate due to damaged bridges within the highway system from an earthquake event for Saint Louis was performed by Enke et al. (2008). Their results showed that the indirect loss is significant when compared to the direct loss resulting from bridge damage.

The scope of seismic risk assessment gets larger as new methodologies for seismic risk analysis that provides a basis for developing mitigation plans and policies, emergency preparedness, and response and recovery planning are accessible. Risk assessment software tools like HAZUS and REDARS 2 result in estimates of hazard-related damage and loss estimates before, or after, a disaster occurs. Recent studies conducted on transportation networks place a strong emphasis on indirect costs due to traffic flow and travel times. A study by Stevanovic and Nadimpalli (2010), presents the impact of degree of damage on the traffic in terms of user delay costs and determine how the earthquake damage influence traffic in terms of AM peak, mid day, PM peak, and off peak traffic. The study found some links that are susceptible to damage on one scenario are critical in carrying detour traffic to other scenario. The cost estimate indicated that the maximum impacts would be imposed on PM traffic. 
Dusicka et al. (2008) developed a GIS model of the roadway and bridge network using new technology developed for the Federal Highway Administration called REDARS2. The research project concentrated on the development of a strategy to prioritize bridges on Oregon's freight routes for seismic retrofit. The data compiled has provided a strong foundation to this research. The following chapters will present a comparable SRA of the bridges in the Oregon highway network given various ground motion hazards.

\subsection{APPLICATION AND FUTURE USE OF OREGON REDARS2 MODEL}

The Oregon REDARS2 model can be useful for both pre-earthquake planning and postearthquake response. Before an earthquake occurs, it can be used to assess the transportation network and formulate a plan for reduction of seismic risk. Different retrofit strategies and prioritizations can be assessed and weighed against each other, and routes of strategic importance or of high seismicity can be identified.

After an earthquake, the model can be used to assist emergency response in numerous ways. For example, it can estimate potential locations within the network where damage is likely to occur and assist with planning rerouting strategies. Potential traffic flow bottlenecks can be identified, and strategies can be formulated for prioritizing bridge or pavement repair following the event.

Further potential applications of the highway network model are detailed in Chapters 1 and 2 of the REDARS2 Technical Manual (Werner 2006). The software is capable of a number of different types of probabilistic and deterministic output that can be interpreted in a variety of ways to assist in seismic risk reduction decision making. Future research and use of the developed model and program will enhance the understanding of bridge seismic vulnerability and emergency response planning in Oregon. This will provide decision makers with some of the tools necessary to assess and appropriately address the weakness of the nation's transportation infrastructure.

\subsection{BRIDGES CONSIDERED IN THE ASSESSMENT}

In total, the study area includes over 1900 bridges. Over 1200 of these bridges lie on major Oregon routes. Table 3 gives a breakdown of the distribution of the bridges on major Oregon routes. Notably, 502 bridges, or $36 \%$ of the bridges considered, lie on Interstate 5, generally considered one of Oregon's major routes as the highway connects to California and Washington states. Table 4 breaks down the predominant types of material of the bridges considered in the assessment.

The NBI database is not a complete description of each bridge. However, it provides sufficient information to allow for general classification. The bridges in this study are classified based on their construction material (Table 1), construction type (Table 2) and the number of spans. This information is contained in three of the 116 fields in the NBI. 
Table 1: Construction Materials Listed in NBI (FHWA, 1995a).

\begin{tabular}{ll}
\hline Description & \\
\hline Concrete & Prestressed Concrete Continuous \\
Concrete Continuous & Wood or Timber \\
Steel & Masonry \\
Steel Continuous & Aluminum, Wrought Iron, or Cast Iron \\
Prestressed Concrete & Other \\
\hline
\end{tabular}

Table 2: Construction Types Listed in NBI (FHWA, 1995a).

\begin{tabular}{ll}
\hline Description & \\
\hline Slab & Suspension \\
Stringer/Multi-beam or Girder & Stayed Girder \\
Girder and Floor beam System & Movable - Lift \\
Tee Beam & Movable - Bascule \\
Box Beam or Girders - Multiple & Movable - Swing \\
Box Beam or Girders - Single or Spread & Tunnel \\
Frame & Culvert \\
Orthotropic & Mixed Types \\
Truss - Deck & Segmental Box Girder \\
Truss - Thru & Channel Beam \\
Arch - Deck & Other \\
Arch - Thru & \\
\hline
\end{tabular}

Table 3: Distribution of bridges on major routes

\begin{tabular}{cc}
\hline Routes & No of Bridges \\
\hline I-5 & 502 \\
I-84 & 200 \\
US-101 & 143 \\
US 26 & 76 \\
I-205 & 82 \\
I-405 & 56 \\
US-30 & 38 \\
US-20 & 32 \\
OR-38 & 18 \\
OR-42 & 54 \\
\hline
\end{tabular}

Table 4 evaluates the predominant types of design of the majority of bridges considered in the assessment. 1053 (54\%) of the bridges considered are of stringer/multi-beam design; 340 (17\%) are slab designed bridges and $310(16 \%)$ are multiple box beams or girders. 
Table 4: Predominant Bridge classes and their proportion

\begin{tabular}{lcc}
\hline NAME & NUMBER & $\mathbf{\%}$ \\
\hline Concrete continuous Stringer/Multi-beam or Girder & 488 & $25 \%$ \\
Prestressed Concrete Stringer/Multi-beam or Girder & 253 & $13 \%$ \\
Prestressed Concrete Slab & 183 & $9 \%$ \\
Concrete Continuous Box Beam or Girders - Multiple & 148 & $8 \%$ \\
Concrete Continuous Slab & 117 & $6 \%$ \\
Steel Stringer/Multi-beam or Girder & 106 & $5 \%$ \\
Prestressed Concrete Continuous Box Beam or Girders - & & \\
Multiple & 92 & $4 \%$ \\
Concrete Stringer/Multi-beam or Girder & 85 & $4 \%$ \\
Prestressed Concrete Box Beam or Girders - Multiple & 70 & $4 \%$ \\
Prestressed Concrete Continuous Stringer/Multi-beam or & & \\
Girder & 64 & $3 \%$ \\
Steel Continuous Stringer/Multi-beam or Girder & 55 & $3 \%$ \\
Concrete Slab & 38 & $2 \%$ \\
Steel Truss - Deck & 38 & $2 \%$ \\
Other & 201 & $10 \%$ \\
\hline
\end{tabular}

Multi-column bents and simply-supported concrete superstructure and simply-supported steel superstructure are the most susceptible for damage. As can be seen on Table B. 1 (APPENDIX $\mathrm{B})$ the median ground motions leading to onset of damage states are the lowest compared to the other types of structures.

Table 5: Bridge Types and number of spans

\begin{tabular}{lcc}
\hline Bridge Type & Single Span & Multi Span \\
\hline Stringer/Multi-beam or Girder & 81 & 970 \\
Box Beam or Girders - Multiple & 51 & 289 \\
Slab & 124 & 218 \\
Truss - Deck & 17 & 75 \\
Girder and Floor beam System & 0 & 31 \\
Truss - Thru & 2 & 22 \\
Frame & 25 & 13 \\
Box Beam or Girders - Single or Spread & 4 & 12 \\
Tee Beam & 1 & 2 \\
Other & 0 & 1 \\
\hline
\end{tabular}

Figure 3 itemizes the year construction was completed of each of the considered bridges in the model. The figure shows that only 609 (31\%) of the bridges were constructed after 1970 . The 
age of construction of the bridges is especially important when assessing seismic vulnerability because little consideration was given to seismic resistance prior to the San Fernando earthquake of 1971 (Roberts 1991). Further, bridges completed before 1960 are beyond or near the end of the 50-year design life.

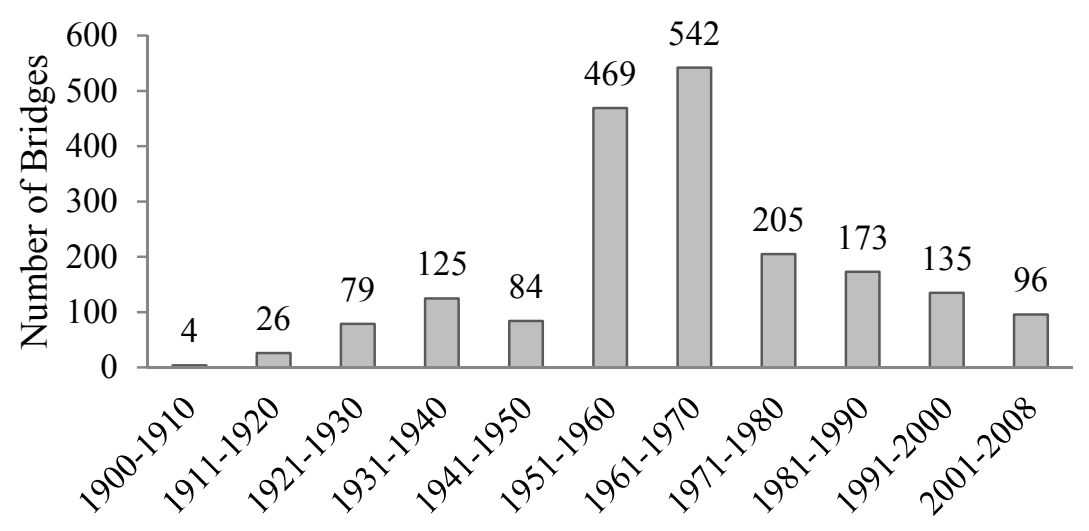

Figure 3: Distribution of year of construction completion 


\subsection{REFINEMENT OF OREGON REDARS2 HIGHWAY NETWORK MODEL}

\subsection{REDARS2 BRIDGE MODEL}

Research has been conducted by Portland State University of the Oregon bridges for seismic vulnerability assessment in 2008 . The study had succeeded in investigating, compiling and manipulating data across multiple civil engineering disciplines to create a dynamic, functional and modifiable GIS model of the network of Oregon freight routes vulnerable to regional seismicity (Dusicka 2008). The results from that study showed a number of limitations in the existing data as well as the software capabilities of REDARS2 had been identified to the point that without additional research and implementation, the results of some aspects of the model were not realistic. Inaccuracies in the soil data and skew angles were identified and corrected.

\subsubsection{Soil Data}

Available structural and geotechnical drawings containing soils information for bridges in the study area were analyzed. The drawings were obtained from ODOT electronic and paper archives. Some of the errors in the soil data were blow count numbers. And for bridges with available borehole data, the soil properties recorded were further analyzed and rectifications made whenever errors were encountered.

Bridges were assessed as potentially liquefiable or non-liquefiable, and the geotechnical information was updated for bridges in the study area. The initial approach for assessing liquefaction for the respective bridges located within the study region was to screen for liquefaction potential based on the geological sedimentary deposits, water table depth less than $15 \mathrm{~m}$ (49ft), evaluation of sensitive clays (Only UCS soil types CL or ML and AASHTO soil types A-4, A-2-4, A-6, and A-2-6 meet these criteria.), and final soil classification. However, since ODOT's Bridge Data System (BDS) did not contain any of the relevant geological data to eliminate any of the structures based on geological composite, the soils profiles were initially only eliminated relative to the water table depth.

Soil survey data which are a product of the National Cooperative Soil Survey, from the USDA website were downloaded and used for screening for liquefaction potential. These soil data maps include water table depth and engineering soil properties such as soil classification according to unified soil classification (UCS) and AASHTO and soil classification based on percentage of clay and liquid limit (LL). Oregon has 39 soil survey areas and each survey area has been mapped at different scales and different levels of detail. Therefore, the map unit symbols, soil properties and interpretations are not compatible completely across the soil survey boundaries which made the task laborious. 


\subsubsection{Skew Angles}

The NBI defines skew angle of the bridge, in degrees, between the centerline of a pier and a line normal to the roadway centerline as shown on Figure 4. For a right bridge with no skew, ANGLE $=0$. If the bridge is curved and has a variable skew, the average skew is recorded. Sometimes the NBI database had shown that ANGLE $=99$ degrees, which signifies a major variation in skews of the substructure units across the length of the bridge. However, in the NBI data there were inconsistencies found in skew angle definitions. To verify the accuracy of the skew angles given in the NBI, first the bridges having a skew angle of greater than 45 degrees were filtered out. For those bridges with a drawing available, the values were compared for consistency. According to the NBI, of the 1938 bridges, 77 bridges have skew angles greater than 45 . Of these 27 were inconsistent with the REDARS2 definition of skew angle, 14 were consistent and 35 were missing drawings. The list of these bridges is given in APPENDIX E. The skew angles for the 27 bridges have been updated and included in the current model.

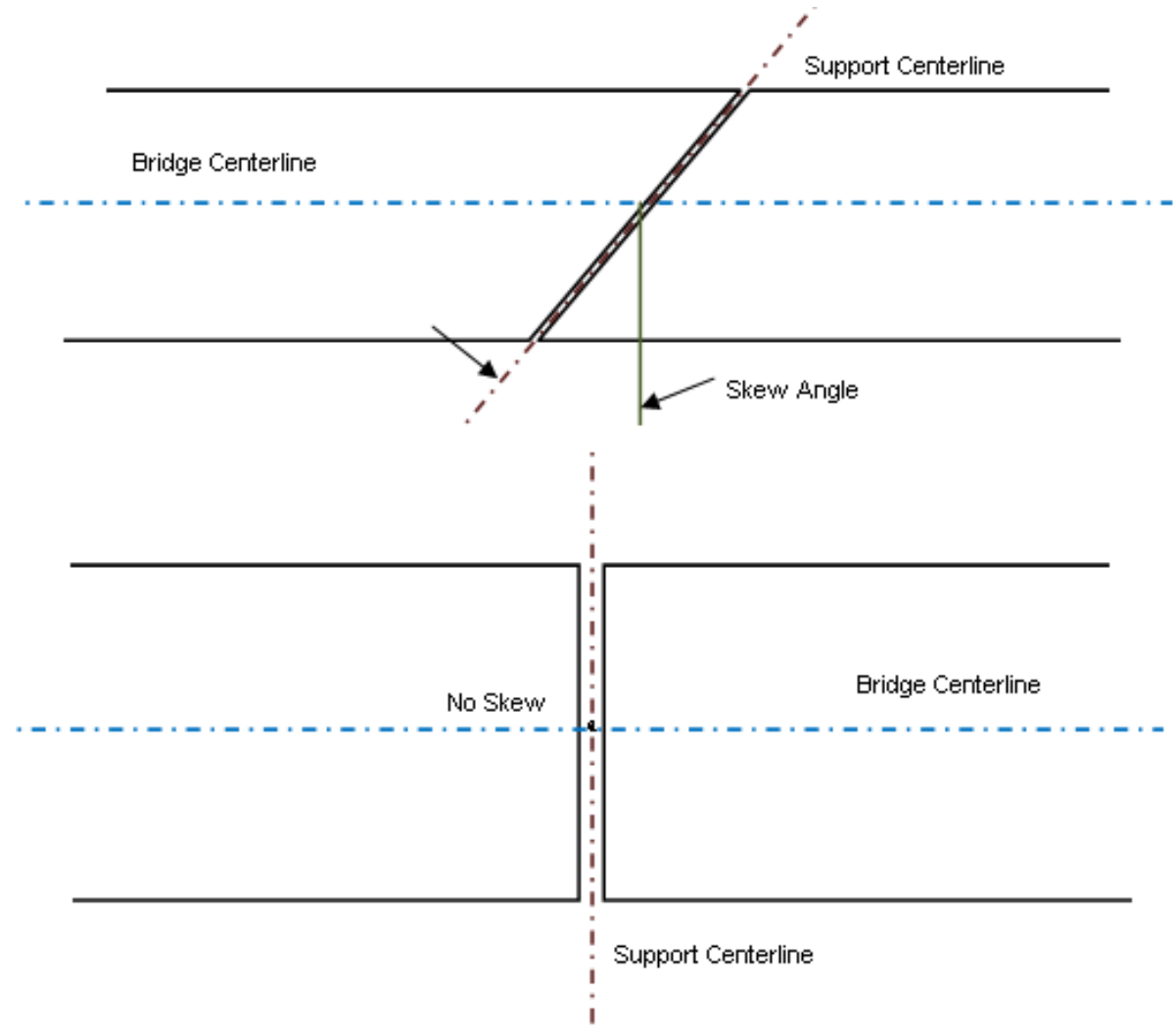

Figure 4: Schematic Depicting Bridge Skew Angle.

\subsubsection{Replacement and Repair Cost}

REDARS2 uses default models for estimating bridge damage due to permanent ground displacement, as well as post-earthquake repair costs, downtimes, and traffic states as a function of the bridge's damage state. But it also gives the user an option to implement user-defined values to override the default REDARS2 data. In the default repair model, the repair cost is 
computed as the product of a repair cost ratio $(R C R)$ which depends on the bridge's damage state, and the replacement cost (REP $=\$ 150 / \mathrm{ft}^{2} \mathrm{x}$ Deck Area), which depends on the bridge's surface area (REDARS2 Technical manual 2006, p.G-27). However, this deck area is in square meters and is multiplied by a $\$$ cost per square feet which underestimates the direct damage cost by almost 10 times.

The assumptions used in the analyses have been reviewed and Oregon specific data, obtained from consultation with ODOT, are incorporated in the model. The replacement costs $\left(\mathrm{REP}_{2}\right)$ are calculated as a product of a base cost of $\$ 165 / \mathrm{ft}^{2}$, the deck area and a factor of 3.2 (to incorporate associated costs such as approaches, traffic control, etc.) with a $\$ 3$ million minimum cost. And when estimating the cost of a new bridge to replace an old bridge, a further multiplication factor of 1.2 is used, because the new bridge is expected to be of a larger dimension than the old one (ODOT 2009). The repair cost is computed as the product of a repair cost which depends on the bridge's damage state, and replacement cost (Table 6).

\section{Replacement Cost $\left(\mathbf{R E P}_{2}\right)=$ max of}

- $\$ 165 / \mathrm{ft}^{2} \times$ the deck area $\times 3.2 \times 1.2$ (when using a "old" bridge to estimate the cost of replacement of a "new" bridge)

- \$3 million

Table 6: Average Repair Cost Estimate

\begin{tabular}{|c|c|c|c|}
\hline \multirow{2}{*}{$\begin{array}{c}\text { Damage } \\
\text { State }\end{array}$} & Default & \multicolumn{2}{|c|}{ User- Defined (Oregon specific) } \\
\cline { 2 - 4 } & $\begin{array}{c}\text { Cost of Repair } \\
\text { Deplacement Cost }=\text { Bridge } \\
\left.\text { Deck Suce Area } \$ 150 / \mathrm{ft}^{2}\right)\end{array}$ & Cost of Repair & $\begin{array}{c}\text { Minimum } \\
\text { Cost }\end{array}$ \\
\hline Slight & $0.03 \times$ Replacement Cost & $\begin{array}{c}0.03 \times \text { Replacement Cost } \\
\left(\mathrm{REP}_{2}\right)\end{array}$ & $\$ 100,000$ \\
\hline Moderate & $0.25 \times$ Replacement Cost & $\begin{array}{c}0.25 \times \text { Replacement Cost } \\
\left(\mathrm{REP}_{2}\right)\end{array}$ & $\$ 750,000$ \\
\hline Extensive & $0.75 \times$ Replacement Cost & $\begin{array}{c}1.0 \times \text { Replacement Cost } \\
\left(\mathrm{REP}_{2}\right)\end{array}$ & $\$ 3,000,000$ \\
\hline Complete & $1.0 \times$ Replacement Cost & $\begin{array}{c}1.0 \times \text { Replacement Cost } \\
\left(\mathrm{REP}_{2}\right)\end{array}$ & $\$ 3,000,000$ \\
\hline
\end{tabular}

\subsection{ROADWAY TRANSPORTATION NETWORK DATABASES AND TRANSPORTATION DATA}

The REDARS2 ${ }^{\mathrm{TM}}$ Import Wizard uses nationally available FHWA datasets to enable prompt creation of REDARS2 ${ }^{\mathrm{TM}}$ study regions. Gathering the various databases required by the 
program's Import Wizard in their necessary formats and getting the Wizard to successfully process the data were significant steps in creating the initialization process.

National Highway Planning Network (NHPN) and Highway Performance Monitoring System (HPMS) are nationally available transportation databases that model the spatial configuration and attributes of the roadways in the study area. The databases are assembled by the individual states and distributed by FHWA.

Roadway systems are divided into a set of sub regions called Traffic Analysis Zones (TAZs) to monitor user trip demands on the roadway system. This subdivision is done by the local and state governments. TAZs are small areas approximately the size of a census tract. OriginDestination (O-D) data estimates the location of travel origins and destinations and the corresponding number of trips from and to all the different TAZs in the region, and is compiled by local metropolitan planning organizations from periodic public surveys. TAZ and O-D data provide REDARS2 with a means to calculate travel time and demand between the different subregions of the state as well as value or economic loss when a particular route is shut down. The transportation data was located in the previous study done by PSU (Dusicka 2008).

A refined the State Wide Traffic Data of the recently completed statewide network and Traffic Analysis Zone (TAZ) system that more closely represents the State has been acquired from Oregon Department of Transportation's Transportation Planning and Analysis Unit. The old National Highway Planning Network (NHPN) which has 2473 links covering interstates, major US and state highways and urban arterials (Figure 5) and the refined network, which is adjusted for roads only, includes nearly 54,000 links, including comprehensive statewide coverage and $5800+$ segments out of state (Figure 6). And the old limited TAZ system has 146 zones, including 25 externals and 4 zones in Clark County, WA (Figure 7). The enhanced zone system includes about 2950 zones of which 2583 in Oregon and 377 in WA, ID, NV, and CA (Figure 8).

Using the REDARS2 Import Wizard has proved to be problematic in implementing the available refined transportation data. Data type incompatibility was the main initial issue. The Import Wizard requires the NHPN data in an uncompressed Arc Interchange file format called"e00". NHPN and Highway Performance Monitoring System (HPMS) databases are no longer published in the format that REDARS2 accepts. Therefore, one attempt was to bypass the Import wizard and create the Microsoft Access Database (MDB) files that resemble NHPN and HPMS data that required by the REDARS2. This also has proven to be a hurdle given the lack of documentation provided and the interconnectivity of the data. The Import Wizard creates five MDB files and creating these five files which dependent on each other. After resolving a number of the data related issues, the size of the database has proven to be too large for REDARDS2 to handle. Consequently, the refined State Wide Traffic Data for Oregon was not successfully incorporated into the REDADRS2 model. 


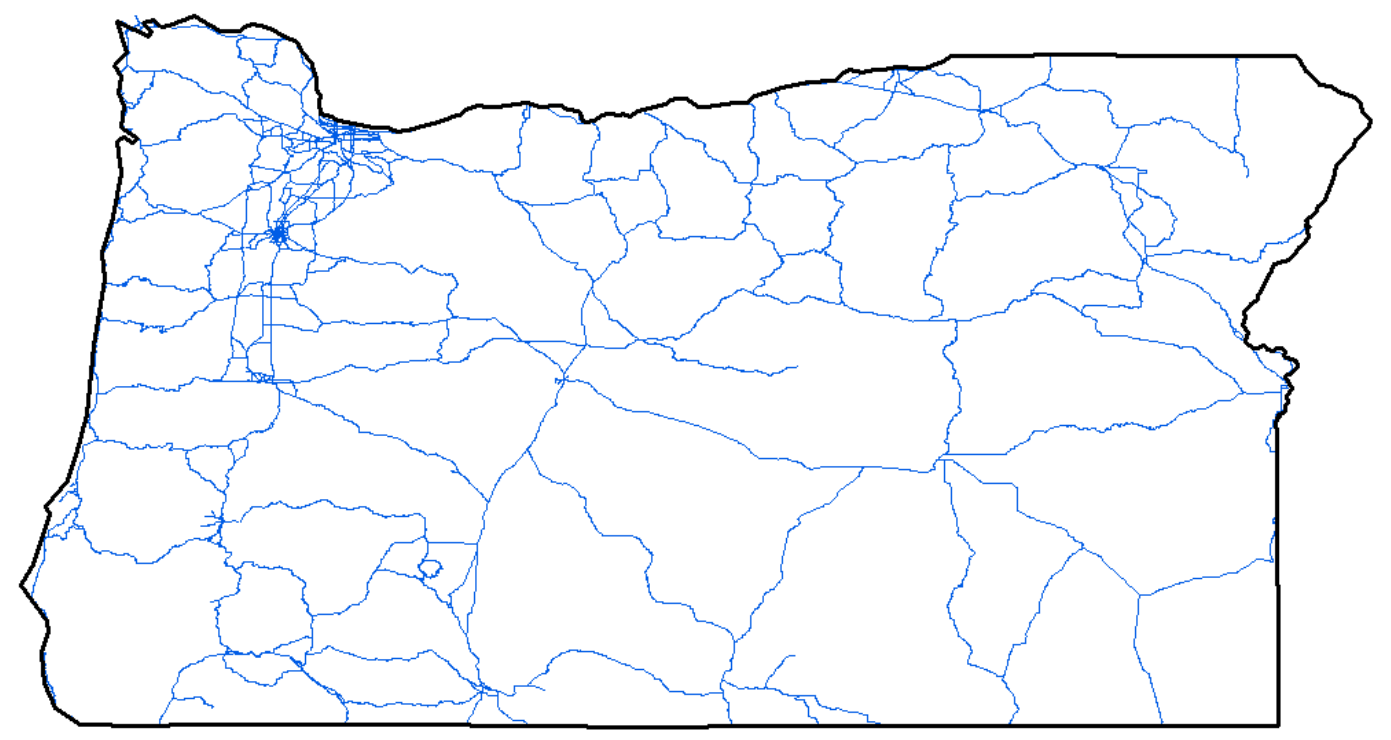

Figure 5: Old FHWA National Highway Planning Network.

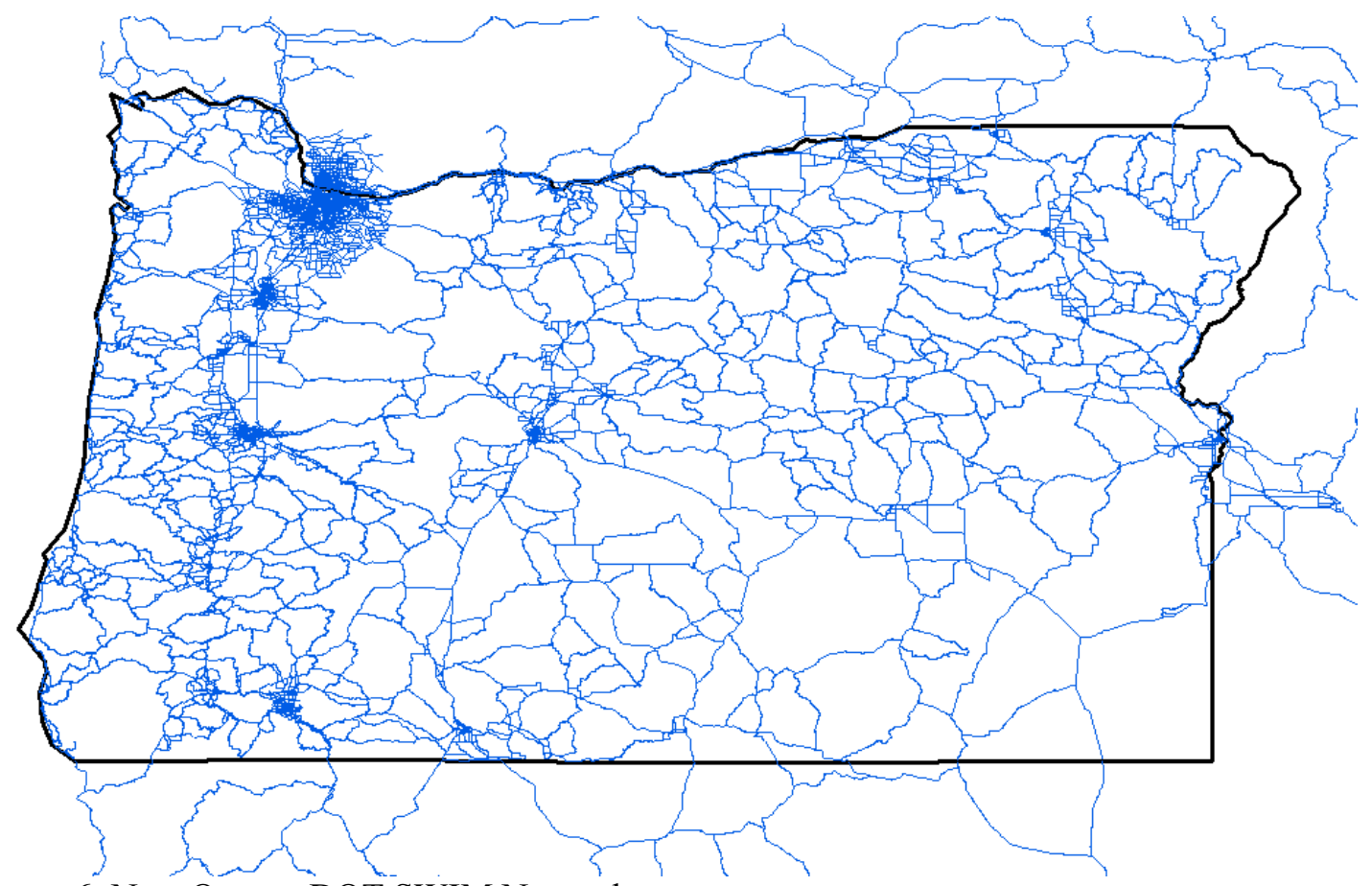

Figure 6: New Oregon DOT SWIM Network 


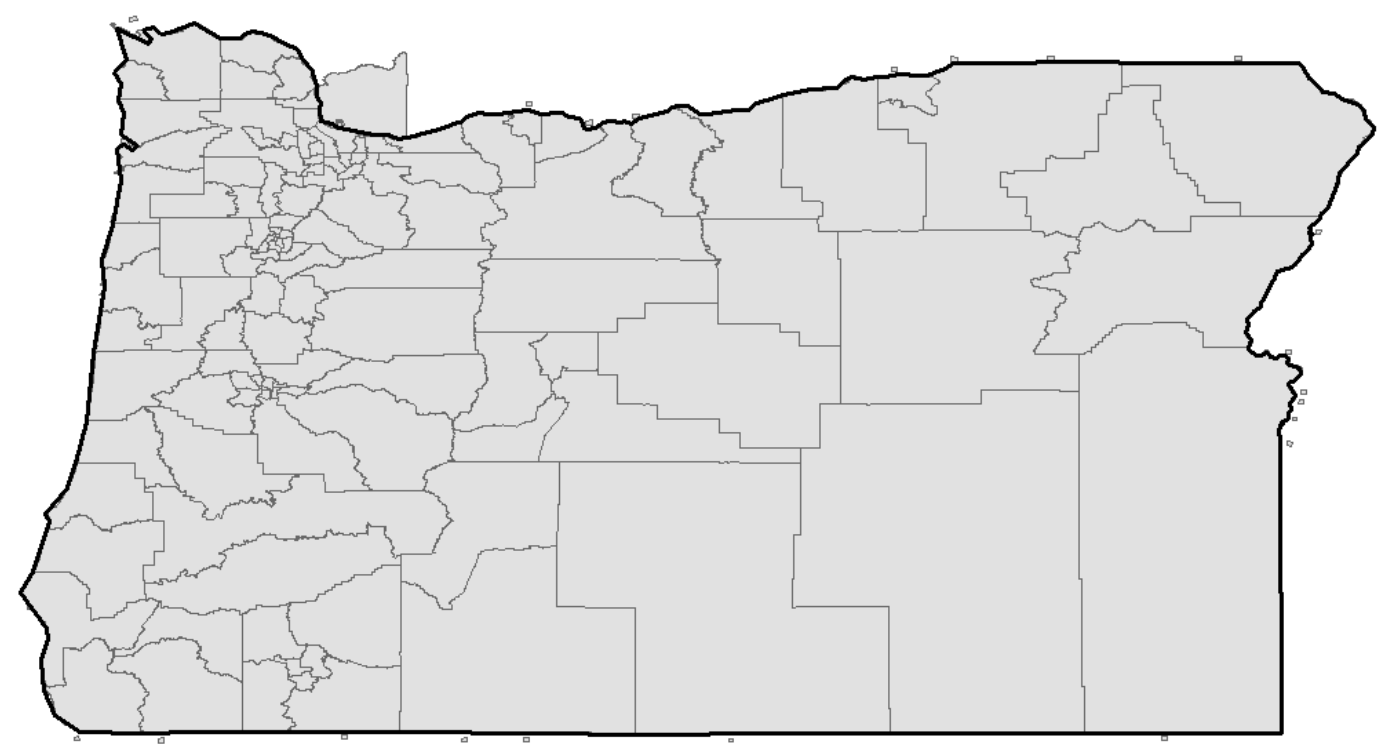

Figure 7: Old Limited TAZ System

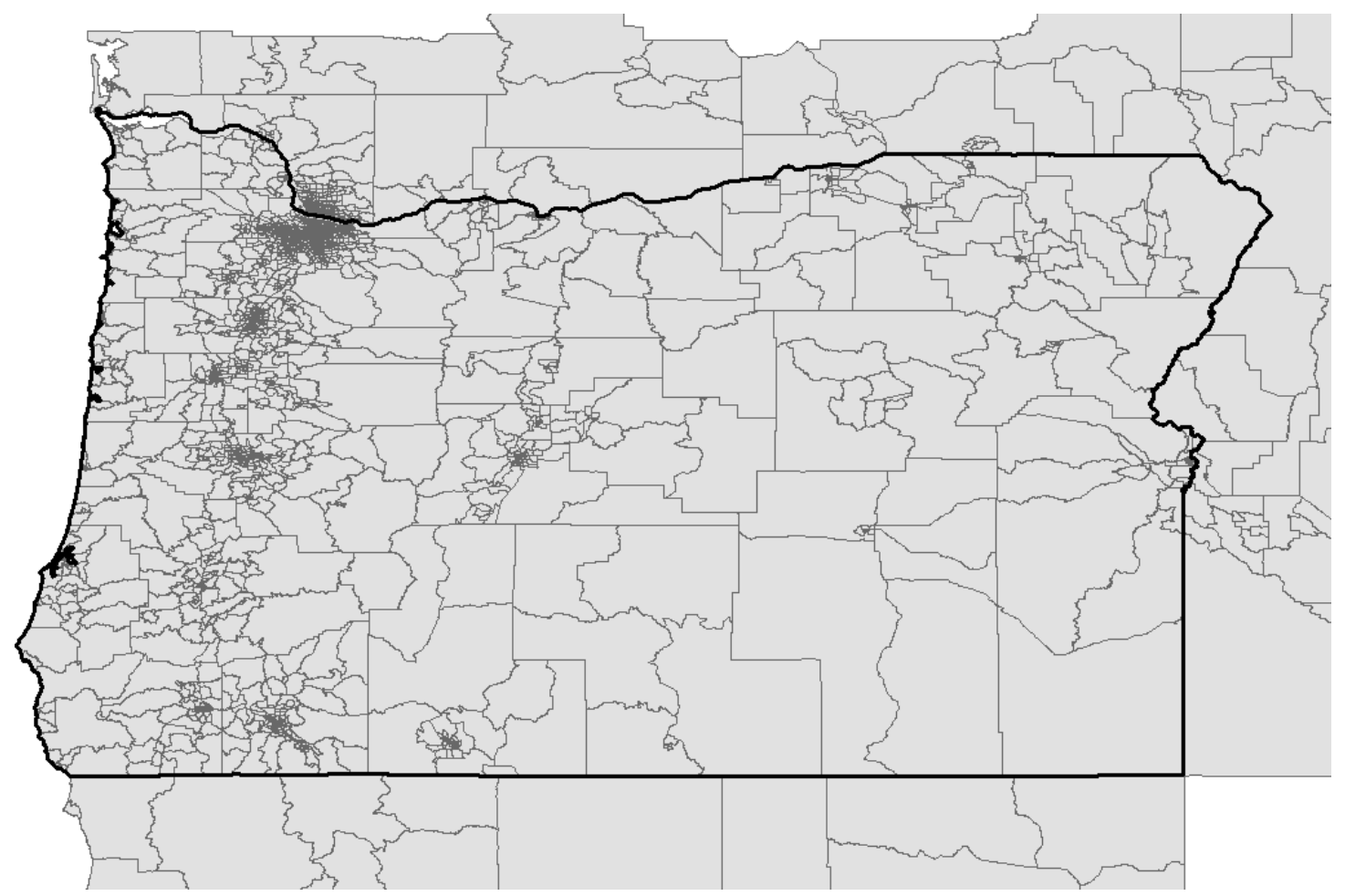

Figure 8: Comprehensive TAZ System 


\subsection{GEOTECHNICAL ASSESSMENT}

\subsection{LIQUEFACTION HAZARD ASSESSMENT}

Liquefaction is a phenomenon in which the strength and stiffness of a soil is reduced by earthquake shaking or other rapid loading. Liquefaction and related phenomena have been responsible for tremendous amounts of damage in historical earthquakes around the world.

Liquefaction occurs in saturated soils, that is, soils in which the space between individual particles is completely filled with water. This water exerts a pressure on the soil particles that influences how tightly the particles themselves are pressed together. Prior to an earthquake, the water pressure is relatively low. However, earthquake shaking can cause the water pressure to increase to the point where the soil particles can readily move with respect to each other.

\subsubsection{Previous investigations}

REDARS2 documents the capability of computing ground displacements due to liquefactioninduced vertical settlement and lateral spread. The first generation study conducted by PSU obtained data for both liquefaction hazard and shear wave amplification factors (NEHRP ratings) for the sites of ODOT bridges (Dusicka 2008). Large scale maps of liquefaction potential and of NEHRP ratings had to be created in the Oregon highway network model since there was no complete list of NEHRP ratings for bridges available for reference when assessing ODOT bridges. Bridges were assessed as potentially liquefiable or non-liquefiable. The initial approach to assessing liquefaction for the respective bridges located within the study region was to screen for liquefaction potential based on the geological sedimentary deposits, water table depth less than $15 \mathrm{~m}$ (49ft), evaluation of sensitive clays, and final soil classification. However, since ODOT's BDS did not contain any of the relevant geological data to eliminate any of the structures based on geological composite, the soils profiles were initially only eliminated relative to the water table depth.

\subsubsection{Liquefaction Assessment in REDARS2}

The Tokimatsu-Seed (1987) model is used in the assessment of liquefaction induced vertical settlement (Figure 9). To apply this model, peak ground acceleration and soil data is input and identification of layers that could settle is required. The soil data that go into this are the corrected blow count numbers, layers depth below the ground surface, the thickness and the layers total overburden pressure and effective overburden pressure. Basic calculations in Tokimatsu-Seed model has the form of curves that define the combination of demand cyclic stress ratio and corrected blow counts that lead to various fixed values of volumetric strain. 


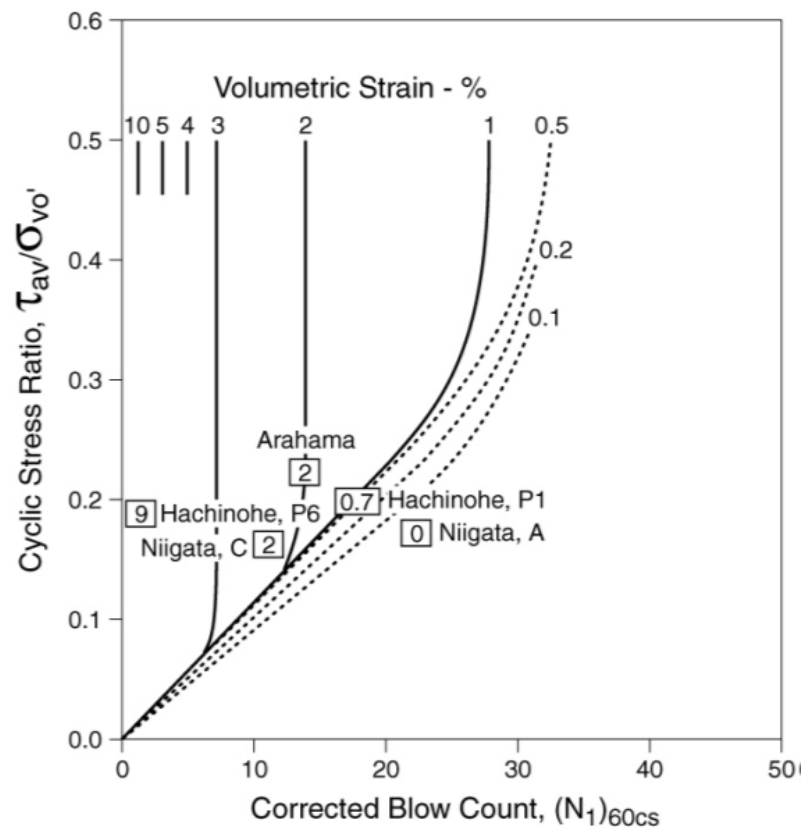

Figure 9: Liquefaction-Induced Volumetric Strains for Each Saturated Sand Layer in Site (TokimatsuSeed, 1987)

The demand cyclic stress ratio, CSR is computed as a function of peak ground acceleration (PGA), total overburden pressure, effective overburden pressure, gravity and a depth dependent stress reduction function. And with this cyclic stress ratio and the layer's corrected blow counts $\left(\mathrm{N}_{1}\right)_{60}$, equations that represent the various Tokimatsu-Seed volumetric-strain curves are used to determine that layer's volumetric strain for a particular earthquake. Volumetric strain is then multiplied by its thickness in order to obtain the change in thickness of that layer. This is done for each saturated layer and the changes in thickness are added in order to obtain the total vertical settlement at the site (Werner et al. 2006).

Damage states in REDARS2 are determined from ground motion analysis or the liquefactioninduced peak ground displacement (PGD) analysis. In REDARS2, a 3.9" total settlement is defined as damage state 4 (Extensive damage) and a total settlement of 13.9" is defined as damage state 5 (Complete collapse). Settlements less than 3.9" are considered damage state 1 (No damage). Permanent ground displacement capacities for various bridge damage states before being modified for uncertainties are shown on APPENDIX B. Preliminary observations from the analysis seem to indicate a disproportionate influence in accounting for damage when liquefaction was being considered. Sensitivity analyses traced the issue to REDARS2 internal calculation of settlement, which cannot be altered without reprogramming and the source code is not easily understood due to lack of code comments and provided documentation. Figure 10 shows a sample analyses for damaged bridges for an earthquake scenario of magnitude 7.0 located near Scotts Mills. A bridge on US 101 over 200 miles away from the earthquake source which experienced a PGA of $0.013 \mathrm{~g}$ showed a damage state 5 or complete collapse. However, preliminary results from a recent validation of this model based on observed damage states after the 1993 Scotts Mills Earthquake indicated unrealistic amounts of damage induced on bridges due to liquefaction. In that earthquake, no bridge collapsed due to liquefaction. Figure 11 shows 
the damaged bridges for an earthquake scenario of magnitude 5.6 at Scotts Mills. A bridge on US 101 which sees a PGA of 0.006 g shows a damage state 5 or complete collapse.

The sensitivity of the model for varying PGA only starts at a very low acceleration, which was found to be approximately $0.00045 \mathrm{~g}$. For values larger than that, it seems to only depend on the blow count number and thickness of layer. Following are graphs that show the sensitivity of the model to varying soil properties and PGA (Figure 12). Hence, REDARS2 cannot be utilized for liquefaction induced seismic analysis without addressing the internal computation algorithms. Therefore, it is necessary to filter out bridges which are potentially liquefiable and do further liquefaction analysis of those bridges independent of REDARS2.

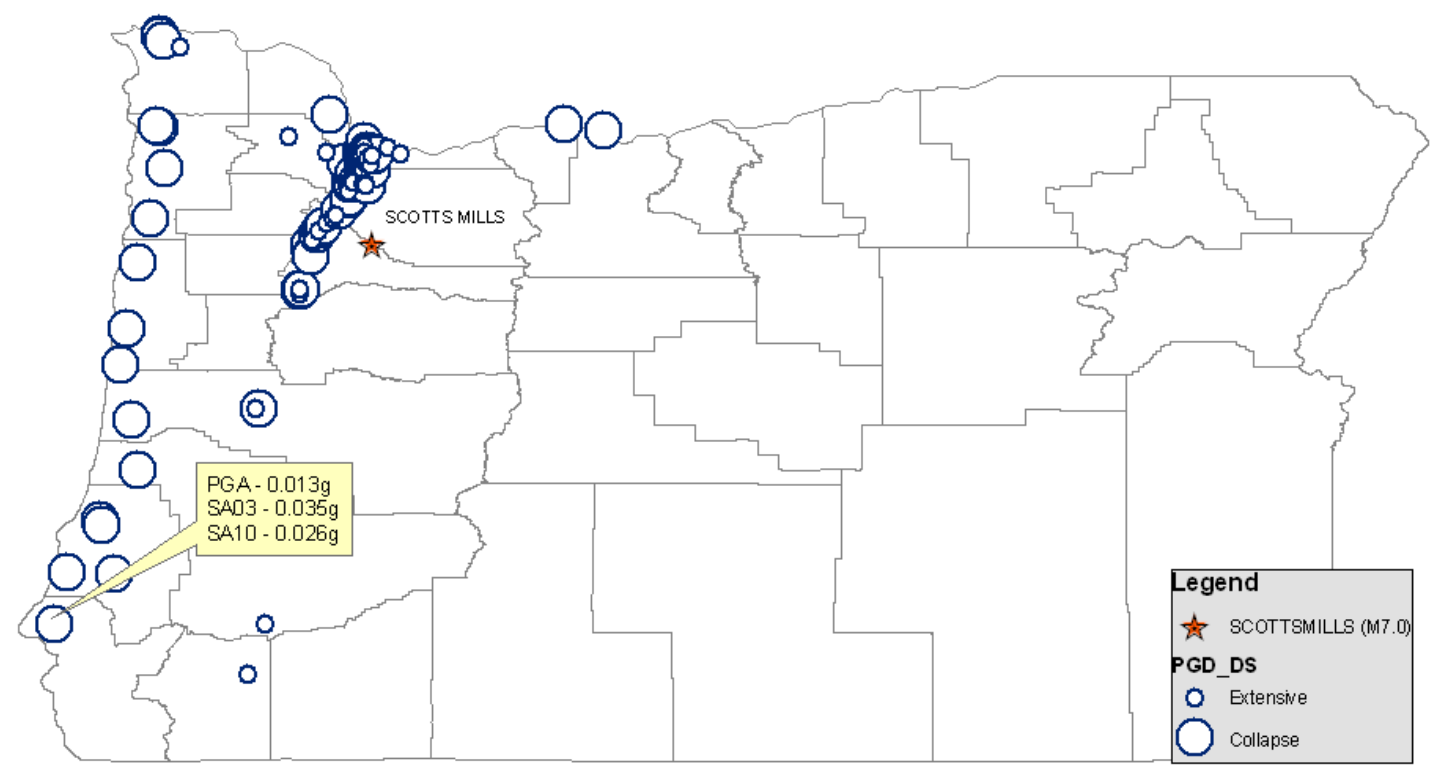

Figure 10: Liquefaction induced damages on bridges for a scenario earthquake at Scotts Mills (M7.0). 


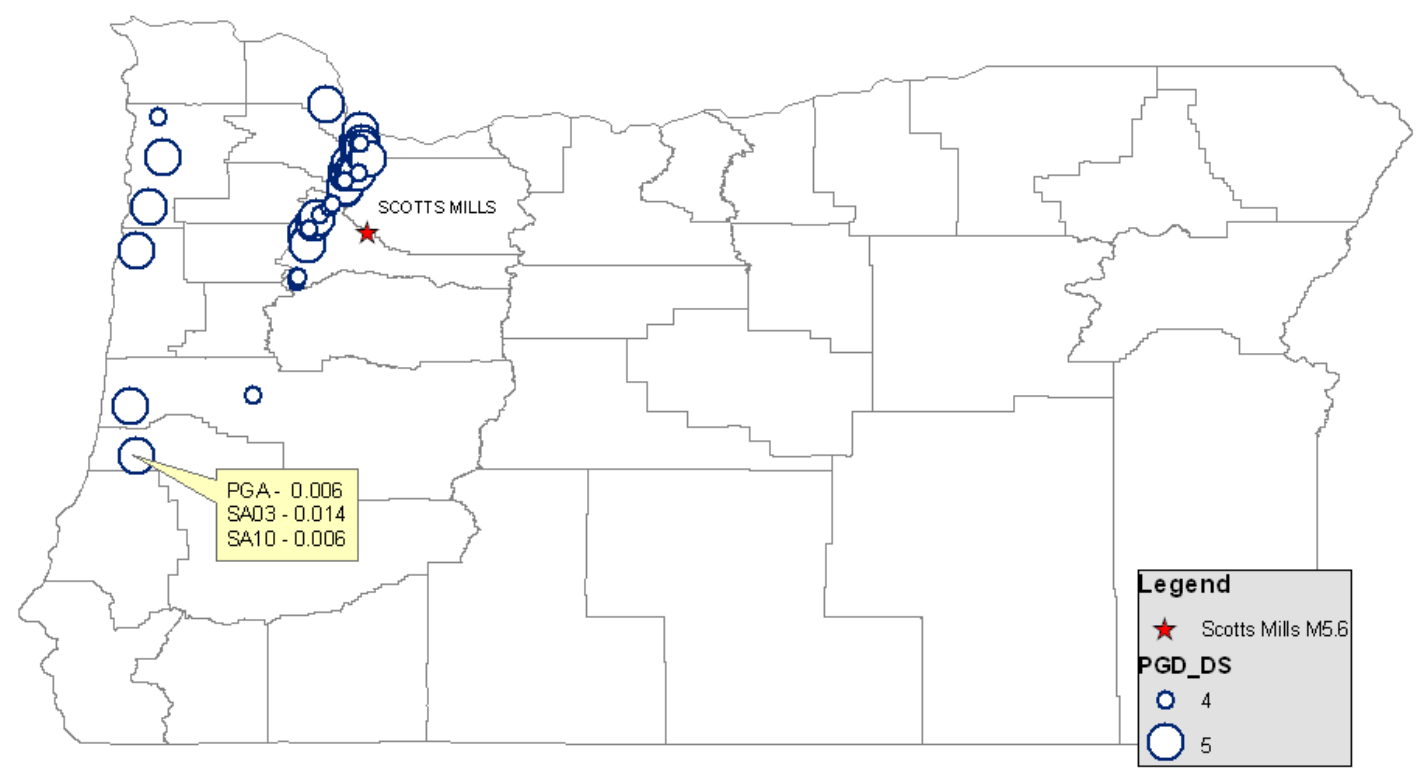

Figure 11: Liquefaction induced damages on bridges for a scenario earthquake at Scotts Mills (M5.6)

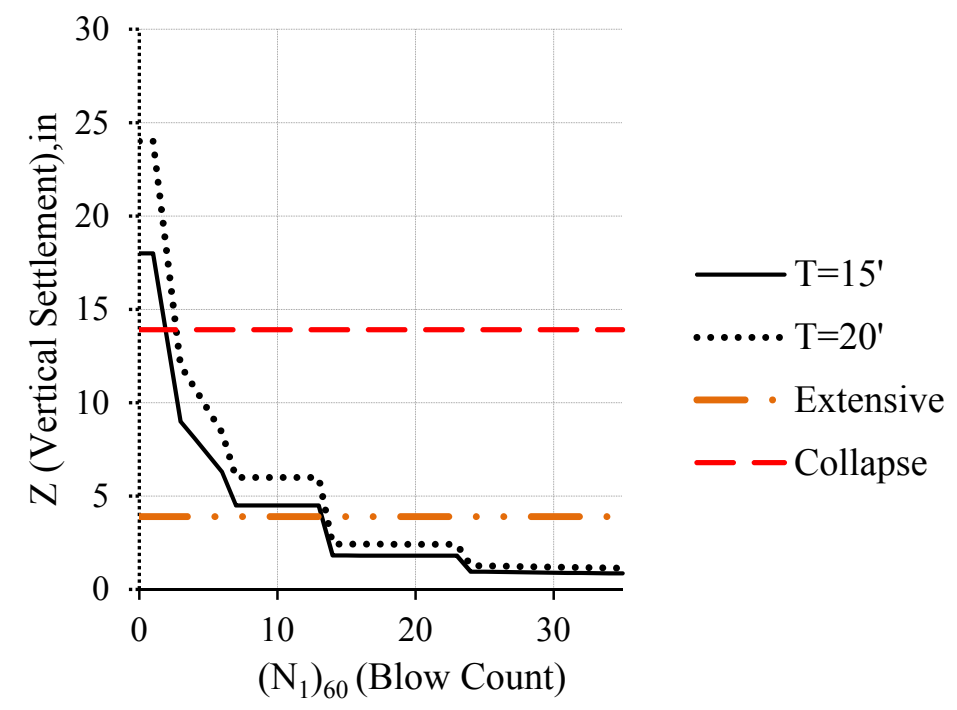

Figure 12: Vertical Settlement vs. (N1)60 for different thickness (T) of layers at PGA $\geq 0.00045$

\subsubsection{Liquefaction Potential Assessment Independent of REDARS2}

The initial step of the liquefaction hazard evaluation is to characterize the relative liquefaction susceptibility of the site based on the geological sedimentary deposits, water table depth and evaluation of sensitive clays, and final soil classification. Soil survey data which are a product of the National Cooperative Soil Survey, from the USDA website were downloaded and used for initial screening for liquefaction potential. These soil data maps include water table depth and engineering soil properties such as soil classification according to unified soil classification (UCS) and AASHTO. 


\subsubsection{Methodology and Analysis}

Oregon has 39 soil survey areas and each survey area has been mapped at different scales and different levels of detail. Therefore, the map unit symbols, soil properties and interpretations do not completely agree across the soil survey boundaries. The soil data maps were then spatially joined with the bridge layer. The interpretation of the map unit symbols was then extracted from the soil data map.

These soil data (SSURGO data - Soil Survey Geographic) are downloaded via the Soil Data Mart (http://soildatamart.nrcs.usda.gov) and an ArcGIS extension, Soil Data Viewer, is used to develop the shape files. Once the soil map is in place, the soil data maps were then spatially joined with the bridge layer. The interpretation of the map unit symbols was then extracted from the soil data map and the bridges were sorted according to the map unit symbols and filtered out according to their liquefaction potential.

\subsubsection{Results of Liquefaction Potential Assessment}

The bridges in the assessment are 1938 and of those almost 500 are flagged as "Can liquefy." Liquefaction hazard assessment of these bridges should be done outside of REDARS2 since REDARS2 calculation of Settlement is not reliable (Figure 13).

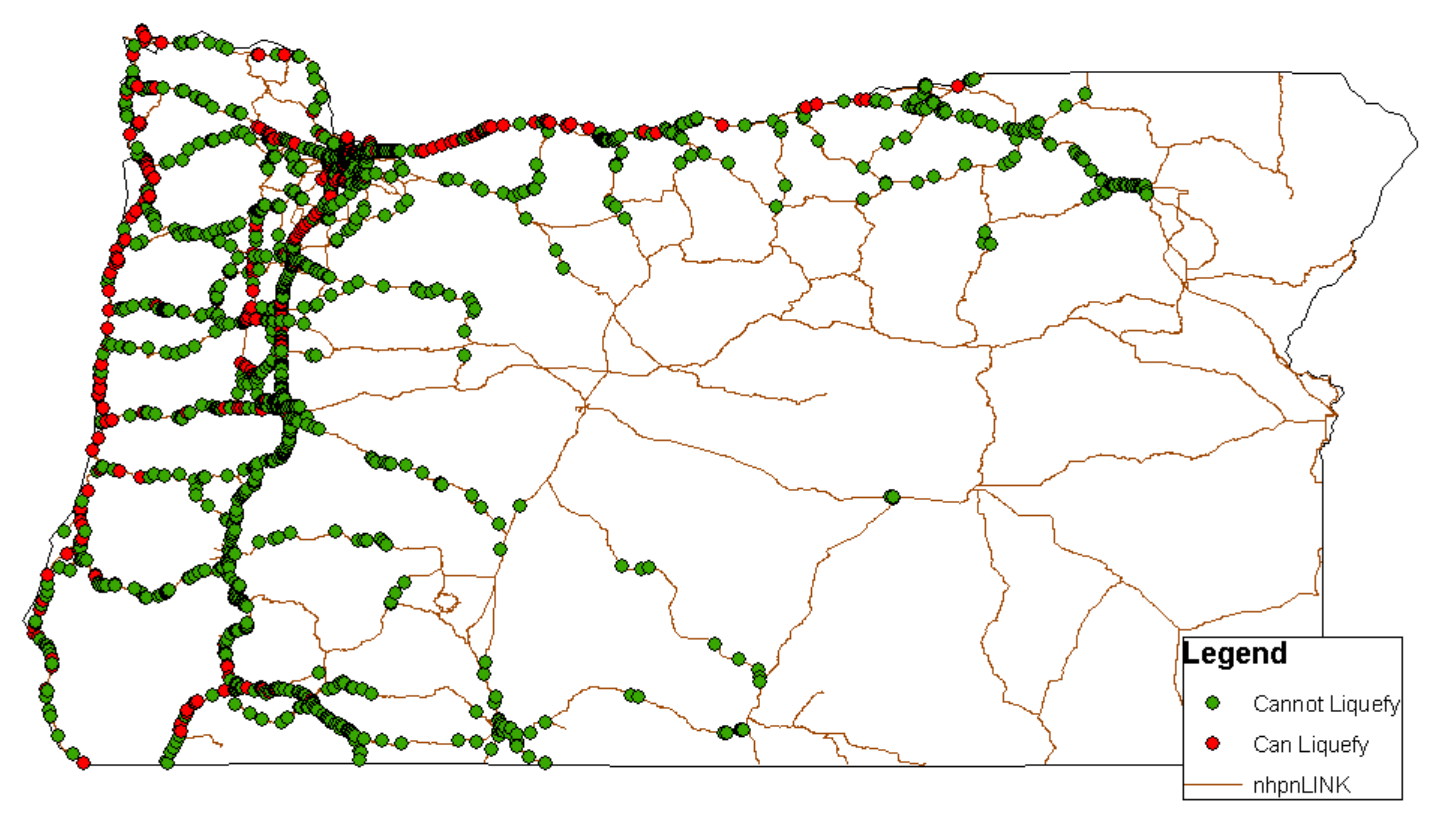

Figure 13: Initial Liquefaction probability screening of bridges. 


\subsection{ANALYSIS OF OREGON MODEL}

\subsection{EARTHQUAKE MODEL}

\subsubsection{REDARS2 Earthquake Model}

REDARS2 uses the ground motion model by Abrahamson \& Silva (1997) for crustal earthquakes in the western United States. Ground motion is expressed as a function of the earthquake magnitude, distance from site, soil conditions, and type of faulting, whether the site is along the hanging wall of footwall of the ruptured fault plane, and inter-event and intra-event uncertainties.

In REDARS2 the Seismic Risk Analysis (SRA) methodology is a synthesis of models developed by earth scientists, geotechnical and structural earthquake engineers, transportation engineers and planners, and economists. The methodology can develop multiple types/forms of results from deterministic or probabilistic approaches and from local to large geographic areas. Such results can be developed for use in pre-earthquake assessment of various options for seismic risk reduction after an actual earthquake (Werner et al., 2006).

REDARS2 typically utilizes publicly available databases to define roadway topology and attributes, bridge locations and attributes, origin-destination (O-D) zones and pre-earthquake trip tables and site-specific NEHRP soil conditions. REDARS2 has an integrated ability to analyze the transportation network as a system, considering both direct losses due to damage and indirect losses due to traffic flow disruption.

The methodology to carry out deterministic or probabilistic seismic risk analysis is depicted in Figure 14. For probabilistic SRA, results are developed for multiple simulations, in which a "simulation" is defined as a complete set of system SRA results for one particular set of randomly selected input parameters and model parameters. The model and input parameters for one simulation may differ from those for other simulations because of random and systematic uncertainties. For deterministic SRA, one set of results is developed either for median input and model parameters or for one set of randomly selected parameters. This multi-disciplinary procedure uses geoseismic, geotechnical and structural engineering, repair / construction, transportation network, and economic models to estimate hazards, component performance, system performance and losses such as economic impacts due to repair costs and losses due to travel time delays.

\subsubsection{Subduction Zone Analysis}

Subduction events are a significant component of the earthquake risk in the Pacific Northwest and Northern California. A major limitation of REDARS2 was encountered in trying to assess the impact of subduction zone earthquakes on the transportation network because only shallow crustal analysis is available (Abrahamson \& Silva 1997). The REDARS2 program however did not include the ability to consider these types of earthquakes and therefore considerably hampers 
the usefulness of the analyses (Cho et al 2006). Therefore to incorporate that capability, instead of modifying the program, shakemaps generated by USGS for Cascadia subduction zone scenario events have been used as ground shaking source. USGS developed shakemaps for a subduction zone event of M9.0 (Figure 15), M8.3 North (Figure 16) and M8.3 South (Figure 17).

For shakemaps, ground motions are estimated using an empirical attenuation relationship, which is a predictive relationship that allows the estimation of the peak ground motions at a given distance and for an assumed magnitude. And these shakemaps can be used as ground shaking source in REDARS2. Below are PGA maps generated by USGS for a subduction zone scenario event.

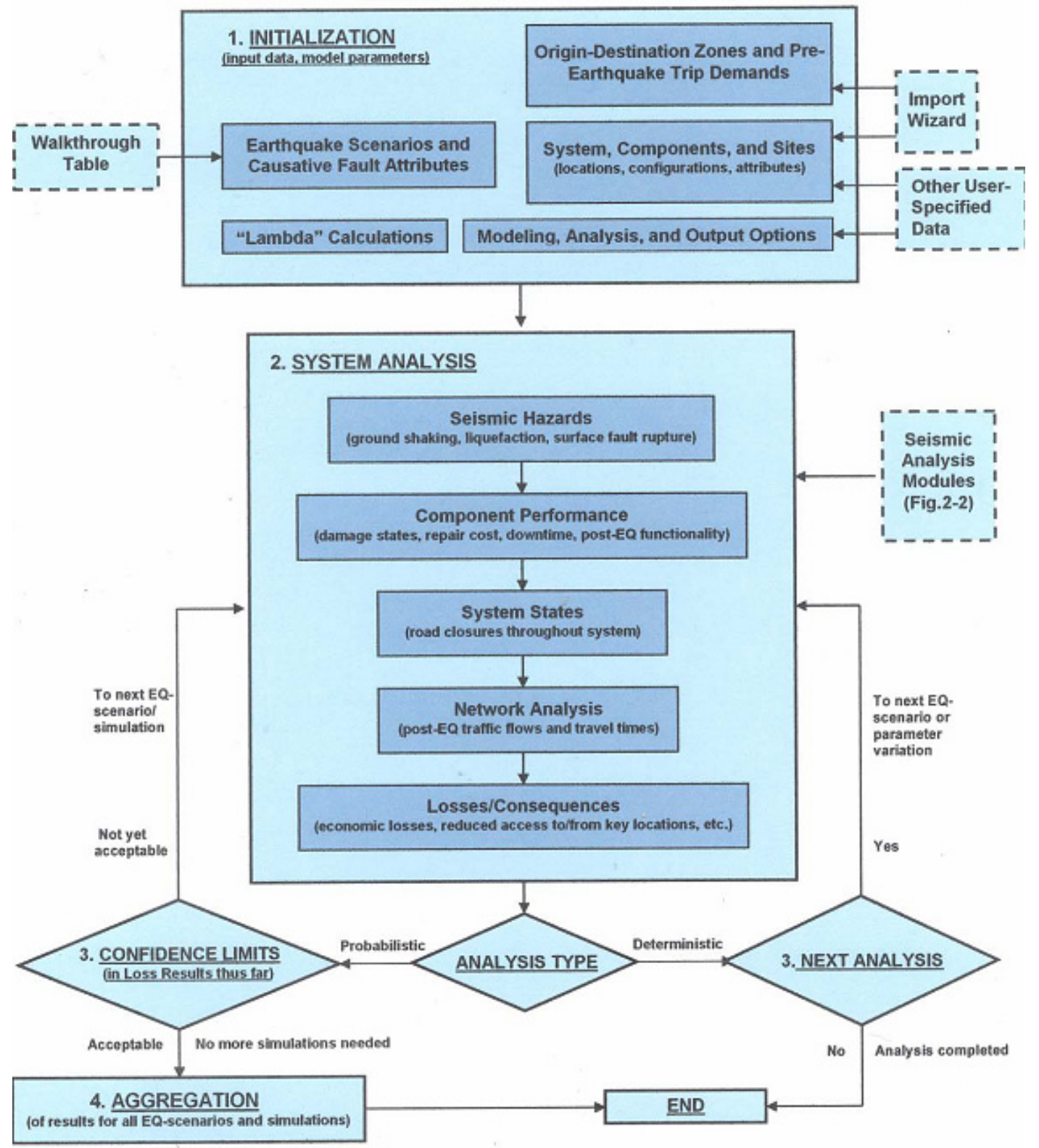

Figure 14: Seismic Risk Analysis of Roadway Systems (TECHNICAL MANUAL: REDARS2 2 METHODOLOGY AND SOFTWARE FOR SEISMIC RISK ANALYSIS OF HIGHWAY SYSTEMS) 


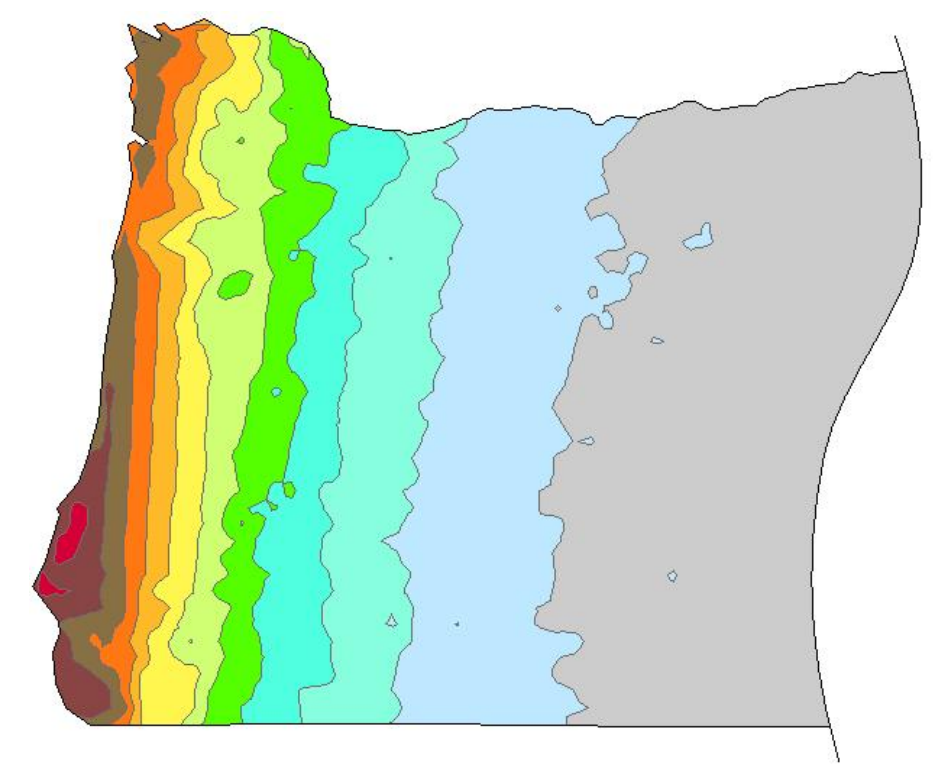

\begin{tabular}{|} 
PGA (g) \\
$0.44-0.48$ \\
$0.40-0.44$ \\
$0.36-0.40$ \\
$0.32-0.36$ \\
$0.28-0.32$ \\
$0.24-0.28$ \\
$0.20-0.24$ \\
$0.16-0.20$ \\
$0.12-0.16$ \\
$0.08-0.12$ \\
$0.04-0.08$ \\
$0.02-0.04$
\end{tabular}

Figure 15: Scenario ShakeMap for CSZ M9.0.

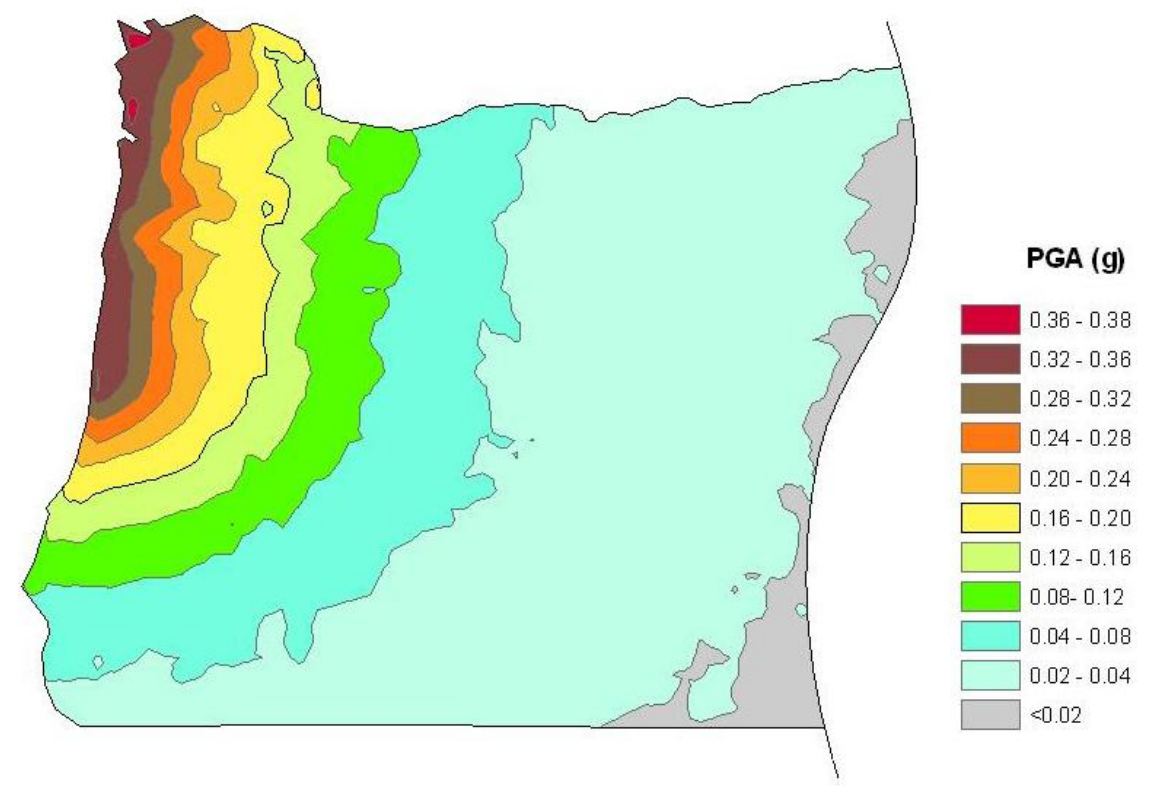

Figure 16: Scenario ShakeMap for CSZ North M8.3. 


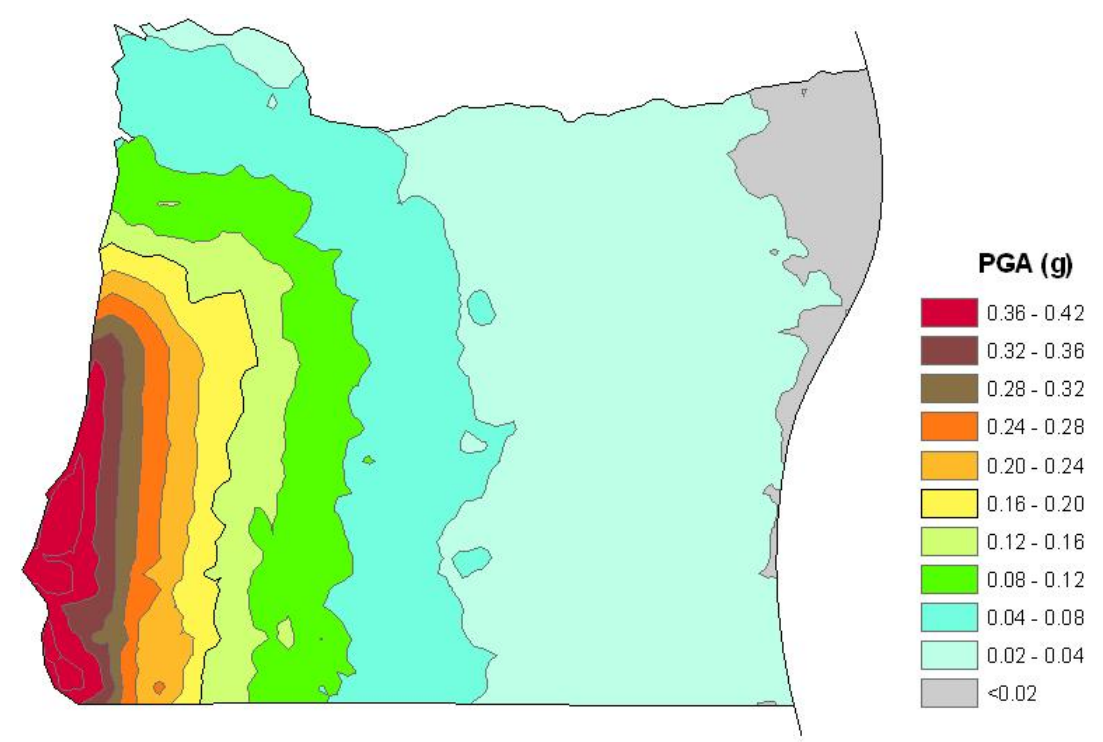

Figure 17: Scenario ShakeMap for CSZ South M8.3.

\subsubsection{HAZUS-MH Earthquake Model}

The HAZUS-MH methodology incorporates available state-of-the-art models in the earthquake loss estimation methodology. These modules include damage loss, such as induced damage due to fire following earthquake and indirect economic loss. A nationally applicable scheme is developed for classifying components. However, unlike REDARS2 interdependence of components on overall system functionality is not addressed by HAZUS. Hence, a network system analysis would need to be performed separately following the damage state analyses (FEMA 2003).

\subsection{COMPONENT DAMAGE ANALYSIS}

\subsubsection{Bridge Damage State model}

In REDARS2, bridge damage resulting from an earthquake event is classified into damage states ranging from no damage to complete collapse. The bridge model utilized for SRA of the Oregon transportation network was based on HAZUS99-SR2, which defines bridge capacities in terms of spectral accelerations leading to the onset of five damage states listed in Table 7 for each of the several "standard bridge" classifications. 
Table 7: Damage States considered in REDARS2 Bridge Model

\begin{tabular}{|c|c|l|}
\hline \multicolumn{2}{|c|}{$\begin{array}{c}\text { Damage State } \\
\text { Designation }\end{array}$} & \multirow{2}{*}{ Description of Typical Expected Damage } \\
\hline Number & Level & \\
\hline 1 & None & Up to first yield. \\
\hline 2 & Slight & $\begin{array}{l}\text { Minor cracking and spalling of the abutment, cracks in shear keys at } \\
\text { abutment, minor spalling and cracking at hinges, minor spalling of } \\
\text { column requiring no more than cosmetic repair, or minor cracking of } \\
\text { deck. }\end{array}$ \\
\hline 3 & Moderate & $\begin{array}{l}\text { Any column experiencing moderate shear cracking and spalling (with } \\
\text { columns still structurally sound), moderate movement of abutment (< } \\
\text { 5.1 cm) (<2 inches), extensive cracking and spalling of shear keys, } \\
\text { connection with cracked shear keys or bent bolts, keeper bar failure } \\
\text { without unseating, rocker bearing failure, or moderate settlement of } \\
\text { approach. }\end{array}$ \\
\hline 5 & Extensive & $\begin{array}{l}\text { Any column degrading without collapse (e.g., shear failure) but with } \\
\text { column structurally unsafe, significant residual movement of } \\
\text { connections, major settlement of approach fills vertical offset or shear } \\
\text { key failure at abutments, or differential settlement. }\end{array}$ \\
\hline 4 & Complete & $\begin{array}{l}\text { Collapse of any column or unseating of deck spans leading to } \\
\text { collapse of deck. Tilting of substructure due to foundation failure. }\end{array}$ \\
\hline
\end{tabular}

Once the spectral acceleration capacity for a given bridge is estimated, a ground motion model is used to estimate the bridge's site-specific demand ground motions (in terms of spectral accelerations $S_{a}(1.0)$ and $S_{a}(0.3)$ ) for each scenario earthquake. The capacity for the bridges is computed including effects of uncertainties. However, the capacity modification factors are developed by statistical analysis for each damage state and are the mean values.

Estimation of ground motions for different scenario earthquakes and simulations includes effects of uncertainties in earthquake magnitude and location, ground motion attenuation characteristics, and soil amplification effects. The Abrahamson-Silva (1997) ground motion model, that is the attenuation in REDARS2, estimates spectral accelerations caused by shallow crustal earthquakes in active tectonic regions of the Western United States, excluding subduction earthquakes. The Abrahamson-Silva ground motion model expresses the natural logarithm of the ground motion as a function of the earthquake magnitude, source-site distance, local soil conditions, and type of faulting, whether the site is along the hanging wall or footwall of the ruptured fault plane, and inter-event and intra-event uncertainties. This functionality is represented through a series of numerical coefficients that are used to compute each term in this equation. Once the bridge's 
demand spectral acceleration is computed for a given scenario earthquake, it is compared to each bridge's spectral acceleration capacity that leads to the onset of each damage state in order to estimate the bridge's damage state for the particular earthquake and simulation. Table B. 1gives the median ground motions leading to onset of various damage states for "Standard" Bridges.

\subsection{TRANSPORTATION NETWORK ANALYSIS}

REDARS2 transportation network analysis of the systems takes into account the spatial distribution of the system and account for the redundancy in the system or lack thereof. One of the procedures of network-analysis was based on Variable-Demand Model (VDM). VDM accounts for a reduction in trip rate and an increase in travel time according to the postearthquake changes in network capacity. The difference in system cost caused by congestion is accounted for. The difference in trip rate is also considered as another type of social cost, together with the value of foregone trips (Werner 2006).

\subsection{ECONOMIC LOSS CALCULATION IN REDARS2}

\subsubsection{Repair Cost}

Estimation of economic impacts of earthquake damage to the system is one of the most important end results from SRA of roadway systems. Bridge damage results not only in high cost of structural repair but also safety concerns by severely disrupting traffic flow which in turn will impact post-earthquake emergency response, repair and reconstruction operations and long term economic consequences due to the valued loss of time when commuter and freight travel slows down due to the disrupted network. From this, it is apparent that earthquake damage to certain components (e.g., those along important and non-redundant links within the system) will have a greater impact on the system performance than will other components.

The SRA methodology uses the bridge and network data to estimate direct and indirect economic losses due to disruption in the system. The SRA considers repair costs, losses due to earthquakeinduced travel-time delays and losses from trips foregone due to earthquake-induced increases in traffic congestion. The default REDARS2 model estimates cost as the product of a unit replacement cost $\left(\mathrm{REP}_{1}\right)$ assumed to be $\$ 150 / \mathrm{ft}^{2}$ and the bridge deck's surface area. However, these repair costs ratios and unit replacement costs can be overridden by the user. Hence, the replacement in this study are calculated as a product of a base cost of $\$ 165 / \mathrm{ft} 2$, the deck area and a factor of 3.2 with a $\$ 3$ million minimum cost. And when estimating the cost of a new bridge with an old bridge, a further multiplication factor of 1.2 is used (Equation 1), because the new bridge is expected to be of a larger dimension than the old one. The repair cost is computed as the product of a repair cost ratio which depends on the bridge's damage state, and the replacement cost $\left(\mathrm{REP}_{2}\right)$ (Table 6).

Equation 1

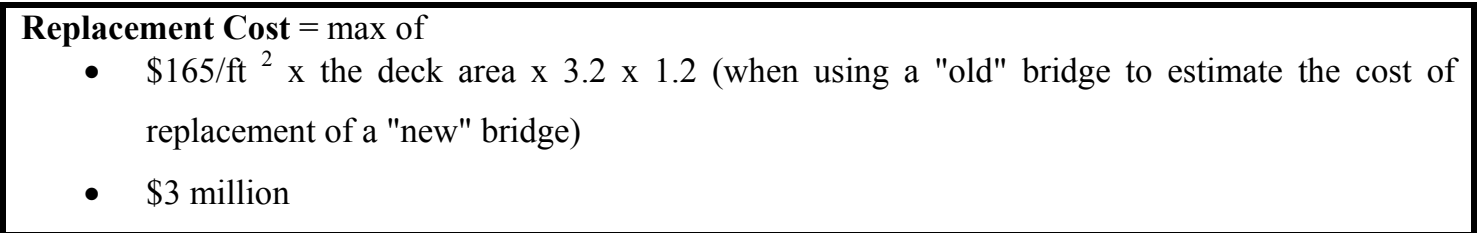


Table 8: Average Repair Cost Estimate

\begin{tabular}{|c|c|c|c|}
\hline \multirow{2}{*}{$\begin{array}{c}\text { Damage } \\
\text { State }\end{array}$} & Default & \multicolumn{2}{|c|}{ User- Defined } \\
\cline { 2 - 4 } & $\begin{array}{c}\text { Cost of Repair } \\
\text { (Replacement Cost }=\text { Bridge Deck } \\
\left.\text { Surface Area } \$ 150 / \mathrm{ft}^{2}\right)\end{array}$ & Cost of Repair & $\begin{array}{c}\text { Minimum } \\
\text { Cost }\end{array}$ \\
\hline Slight & $0.03 \times$ Replacement Cost $\left(\mathrm{REP}_{1}\right)$ & $0.03 \times$ Replacement Cost $\left(\mathrm{REP}_{2}\right)$ & $\$ 100,000$ \\
\hline Moderate & $0.25 \times$ Replacement Cost $\left(\mathrm{REP}_{1}\right)$ & $0.25 \times$ Replacement Cost $\left(\mathrm{REP}_{2}\right)$ & $\$ 750,000$ \\
\hline Extensive & $0.75 \times$ Replacement Cost $\left(\mathrm{REP}_{1}\right)$ & $1.0 \times$ Replacement Cost $\left(\mathrm{REP}_{2}\right)$ & $\$ 3,000,000$ \\
\hline Complete & $1.0 \times$ Replacement Cost $\left(\mathrm{REP}_{1}\right)$ & $1.0 \times$ Replacement Cost $\left(\mathrm{REP}_{2}\right)$ & $\$ 3,000,000$ \\
\hline
\end{tabular}

\subsubsection{Losses due to Travel-Time Delays and Trips Foregone}

REDARS2 ${ }^{\mathrm{TM}}$ methodology for calculating the social cost of earthquake-induced traffic disruption using zone-to-zone trip demands and the corresponding change in travel time. This social cost includes the value of time due to increased traveler time on the roadway and the value of trips foregone. TAZ and O-D data provide REDARS2 with a means to calculate travel time and demand between the different sub-regions of the state as well as value or economic loss when a particular route is shut down. The unit cost and density parameters of each vehicle class are then input in REDARS2. These parameters are: a) the value of one hour of travel time (VOT); and $b$ ) the number of passenger cars equivalent to one Origin-Destination (O-D) unit (PCU) for each class of O-D data represented. VOT parameters are used to calculate economic impact based on loss of travel time after an earthquake; PCU parameters are used to calculate highway densities and travel times.

Oregon representative data that can be used to estimate VOT parameters for Auto, Light Truck and Heavy Truck vehicle classes were supplied by Dr. Chris Monsere of PSU Civil Engineering, and individuals at ODOT's Transportation Planning Analysis Unit (TPAU). This data was based on a calculation weighing several value categories including Oregon average wages and fringe benefits, costs of employees, freight inventory values and average vehicle occupancies. The resulting weighted average VOTs for each vehicle class were: a) Auto: $\$ 15.31 / \mathrm{hr}$; b) Light Trucks: $\$ 19.53 / \mathrm{hr}$; c) Heavy Trucks: $\$ 30.43 / \mathrm{hr}$. Since O-D data only represented trips for one "Truck" class, its associated VOT was interpolated between the values for Light Truck and Heavy Truck vehicle classes considering a traffic composition of $25 \%$ light trucks and 10\% heavy trucks. This resulted in a Truck VOT value of $\$ 22.69 / \mathrm{hr}$. REDARS2's default PCU values for California were 1.0 for the Auto class and 2.5 for the Freight class which were considered reasonable values for Oregon (Dusicka 2008).

The default traffic model assumes a bridge is either fully closed or fully open to traffic after damage has occurred and during repair. Table 9 indicates the variation in times to reach fully open status for the different damage states. The model also accounts for the effect damage to a 
bridge has on the traffic flow of any underlying roadway; these disruption times are the same as above for each damage state except in the event of complete damage, in which case the underlying roadway is assumed to be fully open to traffic 30 days after the event. Any of the default values determining traffic states can be modified by the user, including the default assumption that a bridge is either fully open or fully closed during repair. The user can override this assumption so that a "partially opened" bridge is considered where the number of lanes closed to traffic is a function of the damage state, total number of lanes and the number of bridge spans. Initial analyses conducted on the Oregon highway network model used the default values.

Table 9: Default Traffic States during Repair of Bridge Damage from Ground Motions (Werner 2006)

\begin{tabular}{|c|c|c|c|c|c|}
\hline \multirow{2}{*}{$\begin{array}{l}\text { Bridge } \\
\text { Damage } \\
\text { State }\end{array}$} & \multirow{2}{*}{$\begin{array}{c}\text { Number of } \\
\text { Bridge Spans }\end{array}$} & \multicolumn{2}{|c|}{$\begin{array}{c}\text { Post-Earthquake Traffic } \\
\text { State: } \\
\text { Bridge }\end{array}$} & \multicolumn{2}{|c|}{$\begin{array}{c}\text { Post-Earthquake (EQ) } \\
\text { Traffic State: Underlying } \\
\text { Roadway }\end{array}$} \\
\hline & & $\begin{array}{l}\text { Time after } \\
\text { EQ, days }\end{array}$ & $\begin{array}{l}\text { Percent of Pre- } \\
\text { EQ Traffic- } \\
\text { Carrying } \\
\text { Capacity }\end{array}$ & $\begin{array}{l}\text { Time } \\
\text { after } E Q \text {, } \\
\text { days }\end{array}$ & $\begin{array}{c}\text { Percent of Pre- } \\
\text { EQ Traffic- } \\
\text { Carrying } \\
\text { Capacity }\end{array}$ \\
\hline $\begin{array}{l}\text { None or } \\
\text { Slight }\end{array}$ & - & 0 days & $100 \%$ & 0 days & $100 \%$ \\
\hline Moderate & - & $\begin{array}{l}0-4 \text { days } \\
>4 \text { days }\end{array}$ & $\begin{array}{c}0 \% \\
100 \%\end{array}$ & $\begin{array}{l}0-4 \text { days } \\
>4 \text { days }\end{array}$ & $\begin{array}{c}0 \% \\
100 \%\end{array}$ \\
\hline Extensive & - & $\begin{array}{l}0-12 \text { days } \\
>12 \text { days }\end{array}$ & $\begin{array}{c}0 \% \\
100 \%\end{array}$ & $\begin{array}{l}0-12 \text { days } \\
>12 \text { days }\end{array}$ & $\begin{array}{c}0 \% \\
100 \%\end{array}$ \\
\hline \multirow[t]{3}{*}{ Collapse } & 3 Spans & $\begin{array}{l}0-140 \text { days } \\
>140 \text { days }\end{array}$ & $\begin{array}{c}0 \% \\
100 \%\end{array}$ & $\begin{array}{l}0-30 \text { days } \\
>30 \text { days }\end{array}$ & $\begin{array}{c}0 \% \\
100 \%\end{array}$ \\
\hline & 4 Spans & $\begin{array}{l}0-180 \text { days } \\
>180 \text { days }\end{array}$ & $\begin{array}{c}0 \% \\
100 \%\end{array}$ & $\begin{array}{l}0-30 \text { days } \\
>30 \text { days }\end{array}$ & $\begin{array}{c}0 \% \\
100 \%\end{array}$ \\
\hline & $\geq 5$ Spans & $\begin{array}{l}0-220 \text { days } \\
>220 \text { days }\end{array}$ & $\begin{array}{c}0 \% \\
100 \%\end{array}$ & $\begin{array}{l}0-30 \text { days } \\
>30 \text { days }\end{array}$ & $\begin{array}{c}0 \% \\
100 \%\end{array}$ \\
\hline
\end{tabular}

\subsection{COMPARISON OF DAMAGE STATE ANALYSIS METHODS}

REDARS2 and HAZUS-MH use the same Damage Functions for Bridges. Both use the model that makes use of damage functions developed by Basoz and Mander (1999) for estimating damage state of bridges. However, discrepancies were found in the analysis results.

Some of the discrepancies could be due to differences in the definition of bridge capacity between the two methods. For example, in REDARS2, bridge structures with Single-Column Bents (NBI class 205-206) and Concrete Box-Girder Superstructures (NBI class 605-606) do not have fragility curve defined (Table B. 2 and Table B. 3), hence, these bridge types will have their capacity (a median ground motion leading to onset of damage) of an unclassified bridge . Unclassified bridges in REDARS2 have fragilities defined as $0.80,1.00,1.20$ and 1.70 as their median ground motions leading to onset of damage states; slight, moderate, extensive and collapse respectively for both conventionally and seismically designed bridges. However, in HAZUS-MH these bridges have fragility values that are classified. (Table B. 4). Bridges from 
the NBI class 205, 206, 605 and 606, the median ground motions leading to onset of damage states slight, moderate, extensive and collapse are $0.60,0.90,1.10,1.50$ for conventionally designed bridges and $0.90,0.90,1.10$ and 1.50 respectively for seismically designed bridges. Similarly, steel truss-thru (NBI class 309) and steel truss-deck bridges (NBI class 310) are classified as "simply-supported steel superstructure bridges in REDARS2 and assigned median ground motions leading to onset of damage states slight, moderate, extensive and collapse of $0.25,0.35,0.45$ and 0.70 , whereas, in HAZUS-MH these bridges are not classified and are given fragility values of unclassified bridges (HWB28) of 0.80, 1.00, 1.20 and 1.70. For analyses cases using shakemaps as ground shaking sources, such as, Cascadia subduction event scenarios, Portland hills scenario \& Klamath Falls scenario, the analysis results from REDARS2 showed that some bridges exhibited damage states higher than that of HAZUS-MH. And difference in capacity definition may have played a part.

One source of discrepancy can be due to some variations in the estimation of demand parameters. When using a point ground shaking source (e.g. Scotts Mills scenario), some bridges showed a higher damage state in HAZUS. In REDARS2, the Abrahamson-Silva (1997) ground motion model is adapted. And it estimates spectral accelerations caused by shallow crustal earthquakes in active tectonic regions of the Western United States, excluding subduction earthquakes. In HAZUS there is the option of selecting different attenuation models one of them being Abrahamson-Silva (1997) attenuation model. And one also needs to define parameters of the scenario event such as the epicenter location, moment magnitude, depth, width, orientation and dip angle of fault. The minor differences in damage states in this case could hence be partly attributed to some difference that could exist in parameter definitions. Therefore, definition of these parameters to be more or less the same will make the analysis results to be very comparable. 


\subsection{EARTHQUAKE SCENARIOS USED IN ANALYSIS}

\subsection{INTRODUCTION}

The earthquake scenarios considered for this study are subduction zone earthquakes and crustal earthquakes. The Cascadia Subduction Zone (CSZ) during Oregon's short 150-year historical record, numerous studies have found widespread evidence that very large earthquakes have occurred, most recently about 300 years ago, in January 1700 (e.g., Atwater, 1987; Yamaguchi and others, 1997). The best available evidence and observations indicate that these earthquakes occur on average about every 500 years. Hence, it is important to make an analysis of a scenario CSZ earthquake so as to make a reasonable prediction of the effects of the assumed earthquake. This knowledge of potential damage will allow for planning and preparedness purposes.

Crustal earthquakes occur in the North American plate at relatively shallow depths of 10-20 km (6-12 mi) below the surface. The 1993 magnitude 5.6 earthquake at Scotts Mills, Oregon (Madin et al., 1993) and the 1993 magnitude 5.9 and 6.0 Klamath Falls, Oregon, main shocks (Wiley et al., 1993) are examples of crustal earthquakes that have occurred in Oregon. Consequently, crustal earthquake scenarios at Scotts Mills, Klamath Falls and Portland Metro area are examined for the Oregon Model.

\subsubsection{Crustal Earthquake Scenarios in the Portland Metro Area}

For an earthquake scenario of magnitude 7 at the Portland Metro Area, there were no complete collapses, 24 extensive, 56 major and 49 slight damage states. The losses calculated were \$1,573 million for bridge repair and replacement and $\$ 68$ million travel time related losses. Table 10 gives a breakdown of the number of damages and cost incurred per route (p.41). 


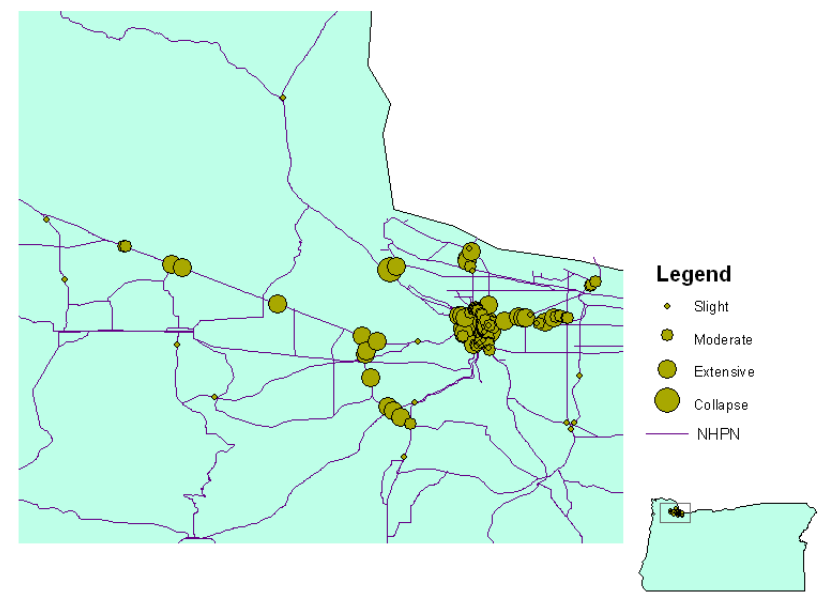

Figure 18: Component Damage States for a Magnitude 6.5 Scenario Earthquake around Portland Hills

\subsubsection{Crustal Earthquake Scenarios in the Scotts Mills}

For an earthquake scenario of magnitude 7 at Scotts Mills, there was one complete collapse, two extensive, two major and three slight damage states. The losses calculated were \$14 million for bridge repair and replacement and $\$ 29$ million in travel time related losses Figure 19. Table 11 gives a breakdown of the number of damages and cost incurred per route (p. 41)

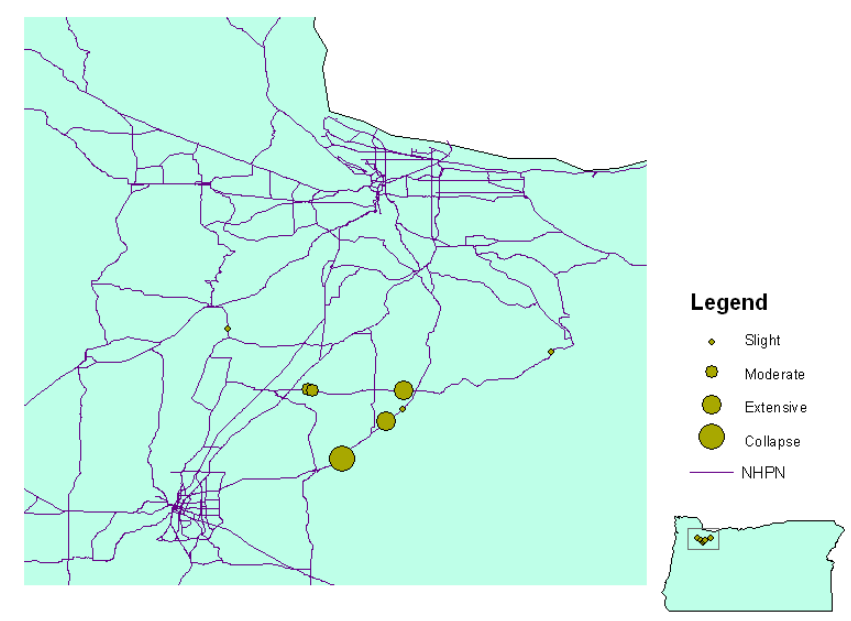

Figure 19: Component damage States for Magnitude 7.0 Scenario Earthquake around Scotts Mills.

\subsubsection{Crustal Earthquake Scenarios in the Klamath Falls}

A magnitude 6.5 scenario earthquake around Klamath Falls resulted in no complete collapses, 7 extensive, 6 moderate and 3 slight damage states. The losses $\$ 109$ million for bridge repair and replacement and $\$ 3$ million in travel time related losses (Figure 20). 
Table 12 gives a breakdown of the number of damages and cost incurred per route (p.42).

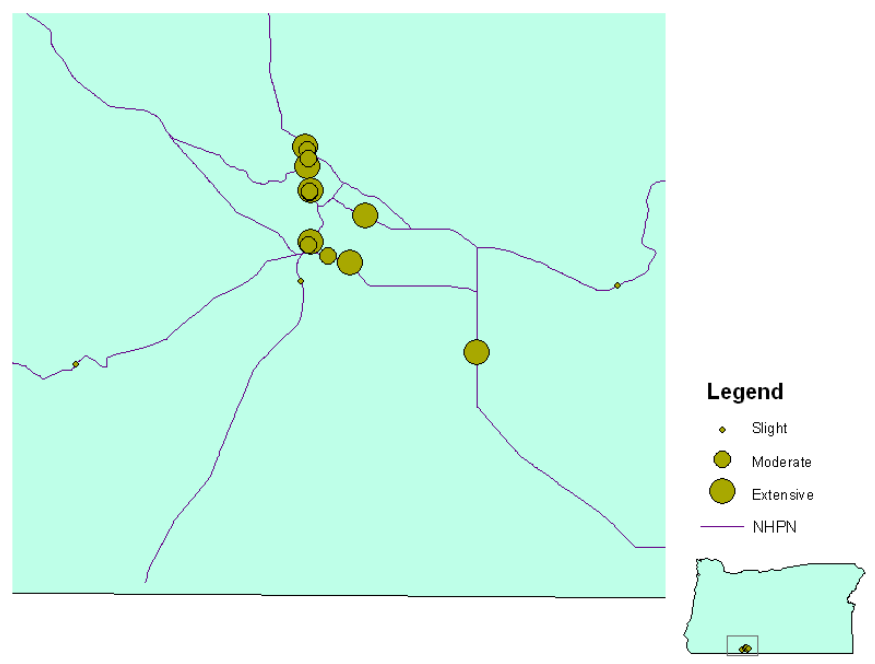

Figure 20: Component Damage States for Magnitude 7.0 Scenario Earthquake around Klamath Falls

\subsubsection{Full Length Cascadia Subduction Zone Earthquake}

The Abrahamson-Silva ground motion attenuation model only estimates spectral accelerations caused by shallow crustal earthquakes in active tectonic regions of the Western United States and excludes the subduction earthquakes. Therefore, for the CSZ earthquake events, a Cascadian Subduction Zone earthquake scenario ShakeMap is used as a ground shaking source.

An earthquake scenario of magnitude 9 at the Cascadian Subduction Zone resulted in 6 complete collapses, 64 extensive, 106 major and 164 slight damage states. The losses calculated were $\$ 1,080$ million for bridge repair and replacement and $\$ 177$ million travel time related losses. Figure 21 shows a map of the component damage states for the western part of Oregon. Table 13 gives a breakdown of the number of damages and cost incurred per route (p. 42). 


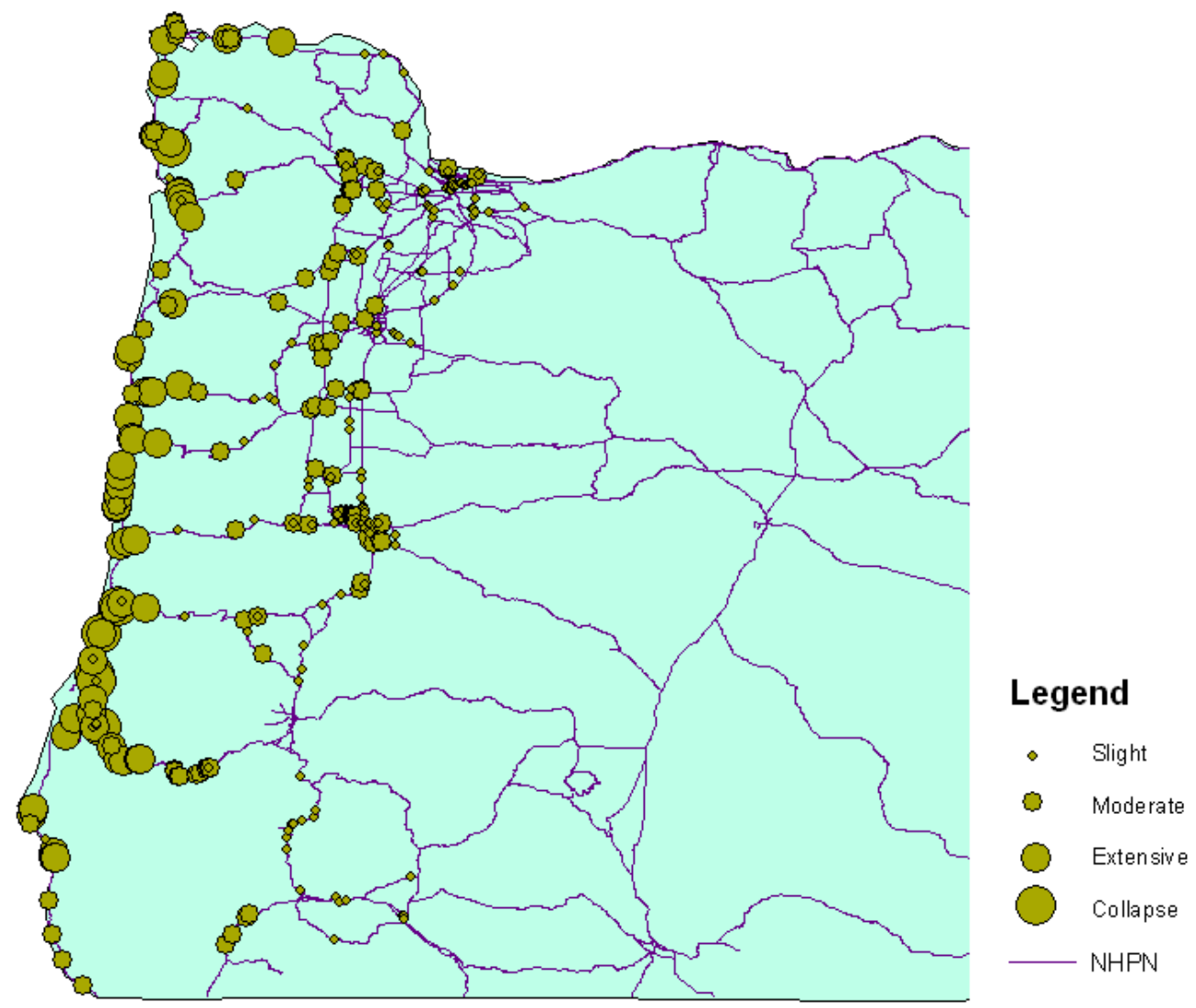

Figure 21: Component Damage States for a M9.0 Cascadia Subduction Zone Scenario earthquake.

\subsubsection{Cascadia Subduction Zone Earthquake near Northern Oregon}

An earthquake scenario of magnitude 8.3 at the Cascadian Subduction Zone near northern Oregon produced no complete collapse, 28 extensive, 32 major and 152 slight damage states. The losses evaluated were \$336 million for bridge repair and replacement and \$8 million travel time related losses. Figure 22 shows a map of the component damage states for the western part of Oregon. Table 14 gives a breakdown of the number of damages and cost incurred per route ( $p$. 43) 


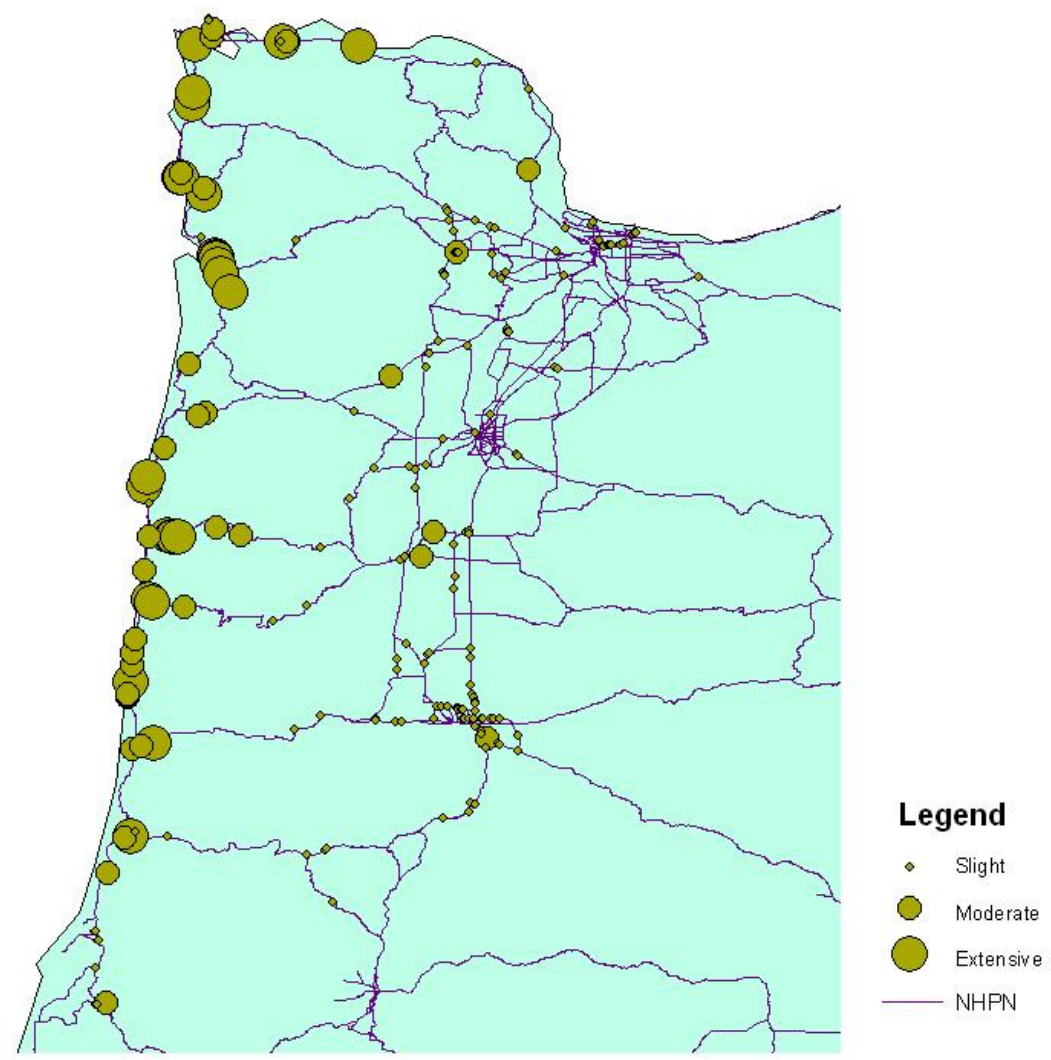

Figure 22: Component Damage States for a Magnitude 8.3 Cascadia Subduction Zone Scenario Earthquake near northern Oregon

\subsubsection{Cascadia Subduction Zone Earthquake near Southern Oregon}

An earthquake scenario of magnitude 8.3 at the Cascadian Subduction Zone near Southern Oregon produced 2 complete collapses, 23 extensive, 33 major and 123 slight damage states. The losses evaluated were \$363 million for bridge repair and replacement and \$94 million travel time related losses. Figure 23 shows a map of the component damage states for the Southwestern part of Oregon. Table 18 gives a breakdown of the number of damages and cost incurred per route ( $\mathrm{p}$. $50)$. 


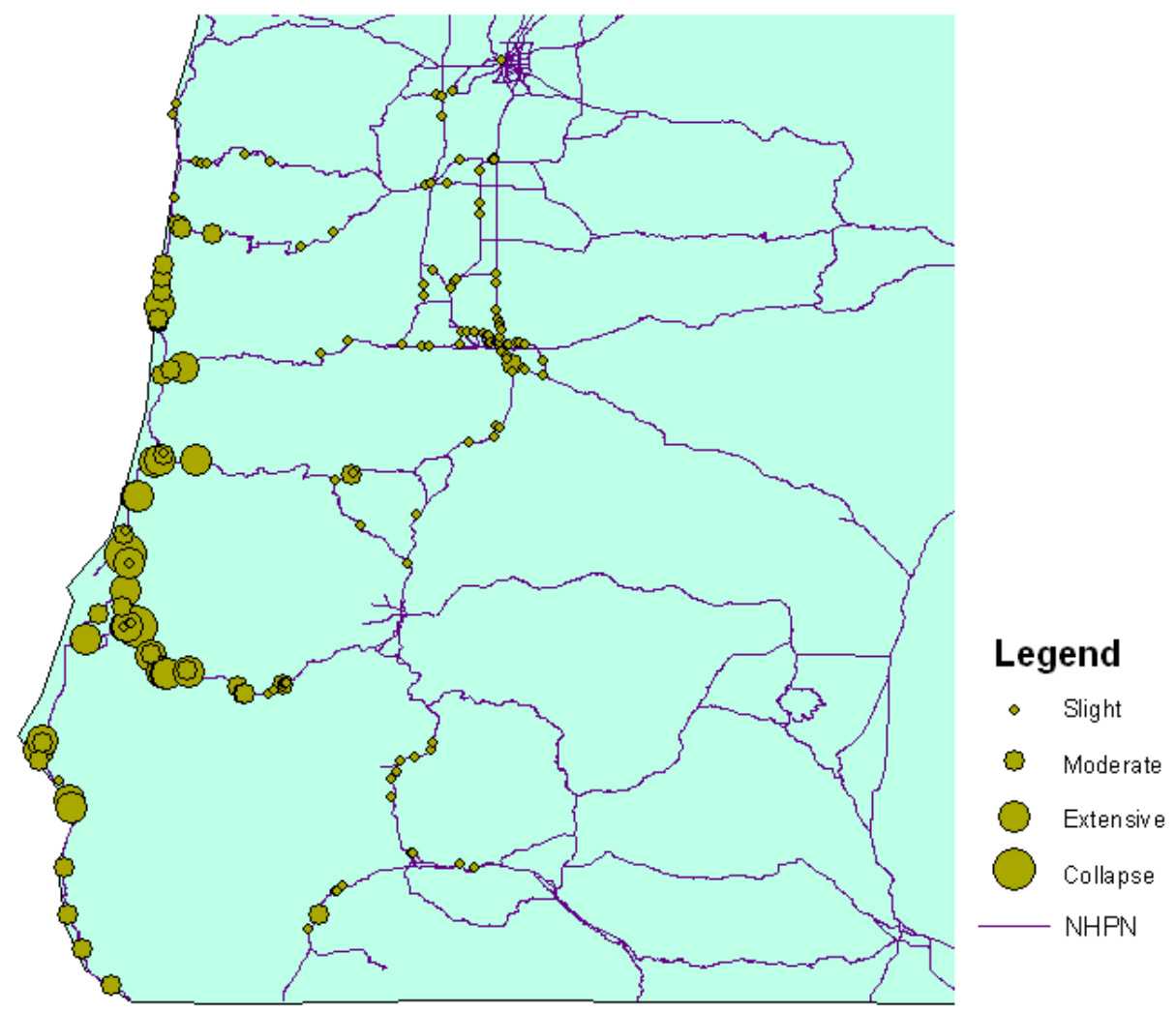

Figure 23: Component Damage States for a Magnitude 8.3 Cascadia Subduction Zone Scenario Earthquake near southern Oregon 


\subsubsection{Summary of number of damaged bridges per route}

Table 10: Portland Hills M6.5 Scenario Analysis Results

\begin{tabular}{|c|c|c|c|c|c|c|}
\hline \multirow[b]{2}{*}{ Route } & \multicolumn{4}{|c|}{ Damage States } & \multicolumn{2}{|c|}{ Economic loss (in Million \$) } \\
\hline & Slight & Moderate & Extensive & Complete & $\begin{array}{c}\text { Bridge } \\
\text { Repair/Replacement }\end{array}$ & $\begin{array}{l}\text { Travel } \\
\text { Time Loss }\end{array}$ \\
\hline I-5 (MWC) & 8 & 12 & 10 & 1 & $\$ 483$ & \\
\hline I-5 (MLL) & 0 & 0 & 0 & 0 & 0 & \\
\hline $\mathrm{I}-5(\mathrm{DJJ})$ & 0 & 0 & 0 & 0 & 0 & \\
\hline $\mathrm{I}-84$ & 1 & 4 & 10 & 1 & $\$ 143$ & \\
\hline US-101 & 0 & 0 & 0 & 0 & 0 & \\
\hline US-26 & 3 & 3 & 7 & 0 & $\$ 63$ & \\
\hline $\mathrm{I}-205$ & 5 & 4 & 0 & 0 & $\$ 14$ & \\
\hline $\mathrm{I}-405$ & 3 & 12 & 9 & 2 & $\$ 494$ & \\
\hline US-30 & 1 & 0 & 1 & 1 & $\$ 122$ & \\
\hline US-20 & 0 & 0 & 0 & 0 & 0 & \\
\hline OR-38 & 0 & 0 & 0 & 0 & 0 & \\
\hline OR-42 & 0 & 0 & 0 & 0 & 0 & \\
\hline Others & 6 & 6 & 11 & 0 & $\$ 254$ & \\
\hline Total & 27 & 41 & 48 & 5 & $\$ 1,573$ & $\$ 68$ \\
\hline
\end{tabular}

Table 11: Scotts Mills M7.0 Scenario Analysis Results

\begin{tabular}{|l|c|c|c|c|c|c|}
\hline \multirow{3}{*}{ Route } & \multicolumn{5}{|c|}{ Damage States } & \multicolumn{2}{c|}{ Economic loss (in Million \$) } \\
\cline { 2 - 7 } & Slight & Moderate & Extensive & Complete & $\begin{array}{c}\text { Bridge } \\
\text { Repair/Replacement }\end{array}$ & $\begin{array}{c}\text { Travel } \\
\text { Time Loss }\end{array}$ \\
\hline I-5 & 0 & 0 & 0 & 0 & 0 & \\
I-84 & 0 & 0 & 0 & 0 & 0 & \\
US-101 & 0 & 0 & 0 & 0 & 0 & \\
US-26 & 0 & 0 & 0 & 0 & 0 & \\
I-205 & 0 & 0 & 0 & 0 & 0 & \\
I-405 & 0 & 0 & 0 & 0 & 1 & 0 \\
Others & 3 & 2 & 2 & 1 & $\mathbf{\$ 1 4}$ & \\
\hline Total & $\mathbf{3}$ & $\mathbf{2}$ & $\mathbf{2}$ & $\mathbf{1}$ & $\mathbf{\$ 1 4}$ & \\
\hline
\end{tabular}


Table 12: Klamath Falls M7.0 Scenario Analysis Results

\begin{tabular}{|l|c|c|c|c|c|c|}
\hline \multirow{2}{*}{ Route } & \multicolumn{4}{|c|}{ Damage States } & \multicolumn{2}{c|}{ Economic loss (in Million \$) } \\
\cline { 2 - 7 } & Slight & Moderate & Extensive & Complete & $\begin{array}{c}\text { Bridge } \\
\text { Repair/Replacement }\end{array}$ & $\begin{array}{c}\text { Travel } \\
\text { Time Loss }\end{array}$ \\
\hline I-5 & 0 & 0 & 0 & 0 & 0 & \\
I-84 & 0 & 0 & 0 & 0 & 0 & \\
US-101 & 0 & 0 & 0 & 0 & 0 & \\
US-26 & 0 & 0 & 0 & 0 & 0 & \\
I-205 & 0 & 0 & 0 & 0 & 0 & \\
I-405 & 0 & 0 & 0 & 0 & 0 & \\
Others & 3 & 6 & 7 & 0 & $\$ 109$ & $\$$ \\
\hline Total & $\mathbf{3}$ & $\mathbf{6}$ & $\mathbf{7}$ & $\mathbf{0}$ & $\mathbf{\$ 1 0 9}$ & \\
\hline
\end{tabular}

Table 13: CSZ M9.0 Scenario Analysis Results

\begin{tabular}{|l|c|c|c|c|c|c|}
\hline \multirow{2}{*}{ Route } & \multicolumn{4}{|c|}{ Damage States } & \multicolumn{2}{c|}{ Economic loss (in Million \$) } \\
\cline { 2 - 7 } & Slight & Moderate & Extensive & Complete & $\begin{array}{c}\text { Bridge } \\
\text { Repair/Replacement }\end{array}$ & $\begin{array}{c}\text { Travel } \\
\text { Time Loss }\end{array}$ \\
\hline I-5 (MWC) & 4 & 1 & 0 & 0 & $\$ 8$ & \\
I-5 (MLL) & 16 & 3 & 1 & 0 & $\$ 14$ & \\
I-5 (DJJ) & 27 & 0 & 0 & 0 & $\$ 5$ & \\
I-84 & 13 & 1 & 0 & 0 & $\$ 10$ & \\
US-101 & 7 & 14 & 36 & 5 & $\$ 685$ & \\
US-26 & 7 & 5 & 0 & 0 & $\$ 9$ & \\
I-205 & 8 & 2 & 0 & 0 & $\$ 10$ & \\
I-405 & 7 & 0 & 0 & 0 & $\$ 2$ & \\
US-30 & 4 & 2 & 2 & 0 & $\$ 26$ & \\
US-20 & 5 & 3 & 5 & 0 & $\$ 19$ & \\
OR-38 & 3 & 2 & 1 & 0 & $\$ 9$ & \\
OR-42 & 4 & 13 & 13 & 1 & $\$ 158$ & \\
Others & 59 & 60 & 6 & 0 & $\$ 125$ & \\
\hline \multicolumn{1}{|c|}{ Total } & $\mathbf{1 6 4}$ & $\mathbf{1 0 6}$ & $\mathbf{6 4}$ & $\mathbf{6}$ & $\mathbf{\$ 1 , 0 8 0}$ & $\mathbf{\$ 1 7 7}$ \\
\hline
\end{tabular}


Table 14: CSZ North M8.3 Scenario Analysis Results

\begin{tabular}{|l|c|c|c|c|c|c|}
\hline \multirow{2}{*}{ Route } & \multicolumn{4}{|c|}{ Damage States } & \multicolumn{2}{c|}{ Economic loss (in Million \$) } \\
\cline { 2 - 7 } & Slight & Moderate & Extensive & Complete & $\begin{array}{c}\text { Bridge } \\
\text { Repair/Replacement }\end{array}$ & $\begin{array}{c}\text { Travel } \\
\text { Time Loss }\end{array}$ \\
\hline I-5 (MWC) & 1 & 0 & 0 & 0 & $\$ 0.4$ & \\
I-5 (MLL) & 18 & 1 & 0 & 0 & $\$ 5$ & \\
I-5 (DJJ) & 3 & 0 & 0 & 0 & $\$ 0.3$ & \\
I-84 & 8 & 0 & 0 & 0 & $\$ 3$ & \\
US-101 & 7 & 18 & 19 & 0 & $\$ 252$ & \\
US-26 & 9 & 0 & 0 & 0 & $\$ 2$ & \\
I-205 & 4 & 0 & 0 & 0 & $\$ 1$ & \\
I-405 & 0 & 0 & 0 & 0 & $\$ 18$ & \\
US-30 & 3 & 2 & 2 & 0 & $\$ 14$ & \\
US-20 & 2 & 2 & 4 & 0 & $\$ 1$ & \\
OR-38 & 4 & 0 & 0 & 0 & $\$ 5$ & \\
OR-42 & 4 & 1 & 0 & 0 & $\$ 35$ & \\
Others & 89 & 8 & 3 & 0 & $\mathbf{\$ 3 3 7}$ & \\
\hline \multicolumn{1}{|c|}{ Total } & $\mathbf{1 5 2}$ & $\mathbf{3 2}$ & $\mathbf{2 8}$ & $\mathbf{0}$ & & \\
\hline
\end{tabular}

Table 15: CSZ South M8.3 Scenario Analysis Results

\begin{tabular}{|c|c|c|c|c|c|c|}
\hline \multirow[b]{2}{*}{ Route } & \multicolumn{4}{|c|}{ Damage States } & \multicolumn{2}{|c|}{ Economic loss (in Million \$) } \\
\hline & Slight & Moderate & Extensive & Complete & $\begin{array}{c}\text { Bridge } \\
\text { Repair/Replacement }\end{array}$ & $\begin{array}{l}\text { Travel Time } \\
\text { Loss }\end{array}$ \\
\hline I-5 (MWC) & 0 & 0 & 0 & 0 & 0 & \\
\hline I-5 (MLL) & 18 & 1 & 0 & 0 & $\$ 5$ & \\
\hline $\mathrm{I}-5$ (DJJ) & 20 & 0 & 0 & 0 & $\$ 4$ & \\
\hline $\mathrm{I}-84$ & 0 & 0 & 0 & 0 & 0 & \\
\hline US-101 & 6 & 16 & 11 & 1 & $\$ 207$ & \\
\hline US-26 & 0 & 0 & 0 & 0 & 0 & \\
\hline $\mathrm{I}-205$ & 0 & 0 & 0 & 0 & 0 & \\
\hline $\mathrm{I}-405$ & 0 & 0 & 0 & 0 & 0 & \\
\hline US-30 & 0 & 0 & 0 & 0 & 0 & \\
\hline US-20 & 7 & 0 & 0 & 0 & $\$ 1$ & \\
\hline OR-38 & 2 & 1 & 1 & 0 & $\$ 7$ & \\
\hline OR-42 & 9 & 10 & 10 & 1 & $\$ 118$ & \\
\hline Others & 61 & 5 & 1 & 0 & $\$ 22$ & \\
\hline Total & 123 & 33 & 23 & 2 & $\$ 364$ & $\$ 94$ \\
\hline
\end{tabular}




\subsection{COMPARISON OF SCENARIOS}

The figures and tables in the previous section show the estimated damage states of bridges and repair/replacement costs and delay-based user costs due to the traffic disruptions for the six scenarios considered.

A scenario earthquake at Portland Hills of a lower magnitude than all other scenarios showed the highest bridge repair/replacement cost. This is attributed to the fact that there is a majority of large bridges are concentrated in that area, hence repair/replacement costs is higher. Although the total number of damaged bridges is less than the subduction zone events, next to a magnitude 9 subduction scenario, the Portland Hills scenario caused a large number of collapses thereby resulting in more extensive damage.

The estimated number of damaged bridges and bridge repair/replacement cost for subduction zone earthquakes scenarios of magnitude 8.3 in the North and South is moderately similar. However, the cost of travel time loss varied greatly. These travel time related losses are inherently low and do not seem realistic. The unexpected values are likely attributed to the travel time loss estimation in REDARS, which has been primarily developed for smaller models and for urban areas. Nevertheless, the relative values are meaningful as the variation of the travel time loss of CSZ North M8.3 (\$8 million) and CSZ South M8.3 (\$94) can be attributed to the network redundancy in the northern part compared to the southern part of the state. The disruption of any of these links or nodes can cause a section of the network to go down, the impact of which is dependent on the redundancy in the system redundancy. The southern scenario caused a cluster of damages on US 101 and there is extensive damage to bridges lying on other routes where the traffic can be diverted such as OR 42 and OR 38. This reduces the redundancy of the system in the area. Similarly, even though similar number of bridges were damaged in the Northern scenario, the network is however more redundant.

The Klamath Falls and Scotts Mills M7.0 scenarios caused a relatively lower damage. This is because the epicenters of these earthquakes are in lightly populated areas compared to the Portland Hills scenario where there are a larger number of bridges in proximity to the epicenter. 


\subsection{SENSITIVITY ANALYSIS}

Sensitivity analysis was conducted to determine how sensitive our model is to changes in the value of the parameters of the model such as soil profile and bridge fragility. These sensitivity investigations are performed as a series of analyses in which the soil profile and fragility values are changed to see how a change in the parameter causes a change in the overall outcome such as damage states and peak ground accelerations and spectral accelerations of the bridges. By showing how the model behavior responds to changes in the values, sensitivity analysis is a useful in model building and evaluation.

\subsection{SOIL PROFILE}

\subsubsection{Liquefaction Settlement Trigger of Damage State}

Liquefaction settlement trigger of damage state largely depends on the PGA. However, the sensitivity of the model for varying PGA only starts at a very low acceleration. For example, a bridge located at US101 (HWY009) over ELK RIVER has the following soil properties. Total overburden pressure $=642 \mathrm{kip} / \mathrm{ft}^{2}$, effective overburden pressure $=174 \mathrm{kip} / \mathrm{ft}^{2}$, thickness of layer is $15^{\prime}$ and the blow count number is 1 . For a PGA $\geq 0.00045 \mathrm{~g}$, the bridge analyses resulted in complete collapse. The PGA for larger PGA values then seems to only depend on the blow count number and thickness \& difference between total and effective over burden pressure of the layer (Figure 12) p.22.

\subsubsection{Earthquake Magnitude}

The ground motion model by Abrahamson and Silva (1997) applies to shallow crustal earthquakes in active tectonic regions of the western United States. Abrahamson and Silva attenuation model expresses the ground motion as a function of the earthquake magnitude, source-site distance, local soil conditions, etc. The sensitivity soil profile on earthquake magnitude was analyzed for the five NEHRP site classifications A- E. For a magnitude 7 earthquake scenario at Scotts Mills area the PGAs and SAs were analyzed and compared for the different soil profiles. For soil profile A, B and C the results were identical. For soil profiles D and $\mathrm{E}$, the results were again identical, but different from $\mathrm{A}, \mathrm{B}$ and $\mathrm{C}$. The following chart shows the analysis result for a bridge that is about $8 \mathrm{~km}$ away from the earthquake epicenter, if the site classification were A, B, or C the PGA, SA03 and SA10 would be $0.44 \mathrm{~g}, 0.87 \mathrm{~g}$ and $0.33 \mathrm{~g}$ respectively and for site class D and E, the PGA, SA03 and SA10 were calculated to be $0.34 \mathrm{~g}, 0.81 \mathrm{~g}$ and $0.51 \mathrm{~g}$ respectively (Figure 24 ). 


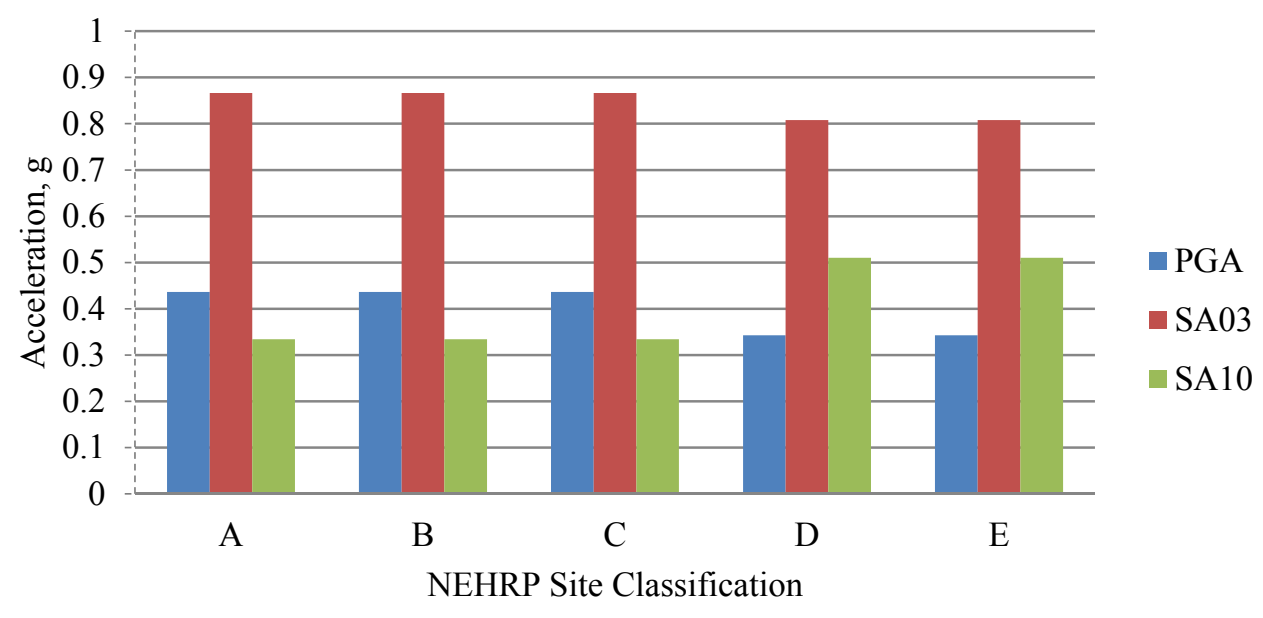

Figure 24: Site Classification Sensitivity on Earthquake magnitude

\subsection{FRAGILITY}

\subsubsection{Fragility Curves}

Bridge fragility curves are needed not only for seismic risk assessment, but also for uses in other activities such as bridge retrofit prioritization and post earthquake emergency response (Nielson 2005). REDARS2 provides default fragility curves originating from HAZUS (FEMA) model for all bridges in the system. These default values can however be replaced by a user-specified model for various individual bridges. Even though this would give a very refined result, it is impractical to implement to all the bridges in the study area. But it should be done for those bridges with unique configurations or whose seismic performance would have a significant effect on the ability of the roadway (Werner G-1). These fragility curves have been generated for typical bridge classes and not for individual bridges as reflected by the approach implemented in this study. The bridge classes are created and the individual bridges are grouped using the National Bridge Inventory (NBI) database as the basis. Medians of these damage functions are given in Table B. 1. These median values are modified to convert from standard to actual bridge. The factors accounted for are skew angle and three dimensional deck arching membrane.

In order to study the sensitivity of the model for the different fragilities, bridge fragilities on the major highway routes have been changed, one route at a time, and analysis results were compared. Figure 25 gives a comparison of fragility curves for a HWB4 (Seismically designed single span bridge) and HWB5 (Concrete, Multi-Column Bent, Simple Support) and as can be seen in the figure, a $50 \%$ probability of damage state 2 (Slight) for HWB5 is close to $0.25 \mathrm{~g}$ where as HWB4 will not see damage until the spectral acceleration is $0.8 \mathrm{~g}$. Fragility curves for a long span bridge that crosses the Mississippi River along I-40 in Memphis, Tennessee were used as another extreme case in understanding the susceptibility of the routes if all the bridges in those routes were very prone to earthquake damage. These curves are based on the un-retrofitted configuration of the bridge that crosses Mississippi River along I-40 (Figure 26). The results achieved were then used in the assessment of the vulnerability of the highway routes and recommendation for retrofit. The number of bridges damaged for the different fragilities are shown below. 


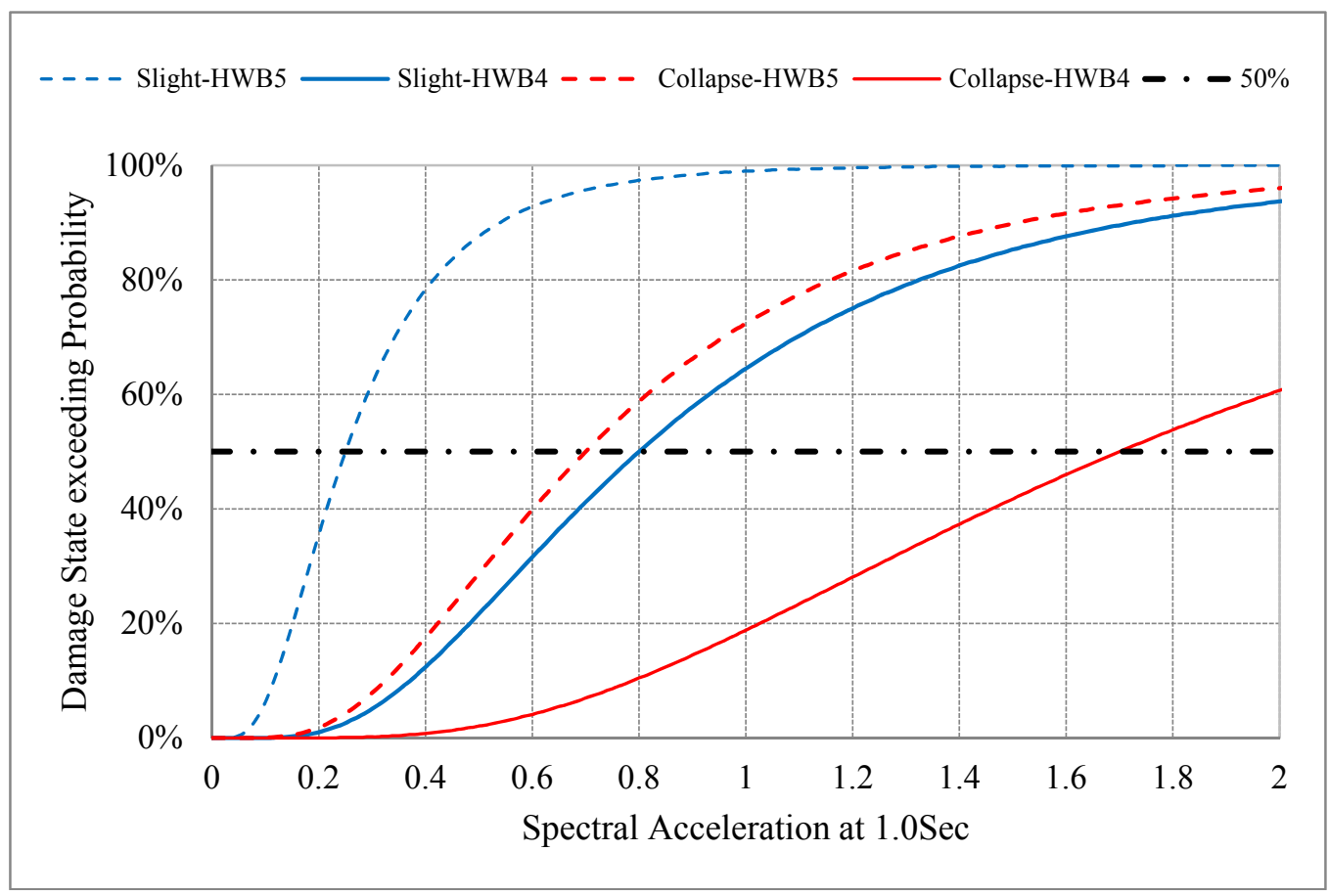

Figure 25: Fragility curve comparison of HWB4 and HWB5.

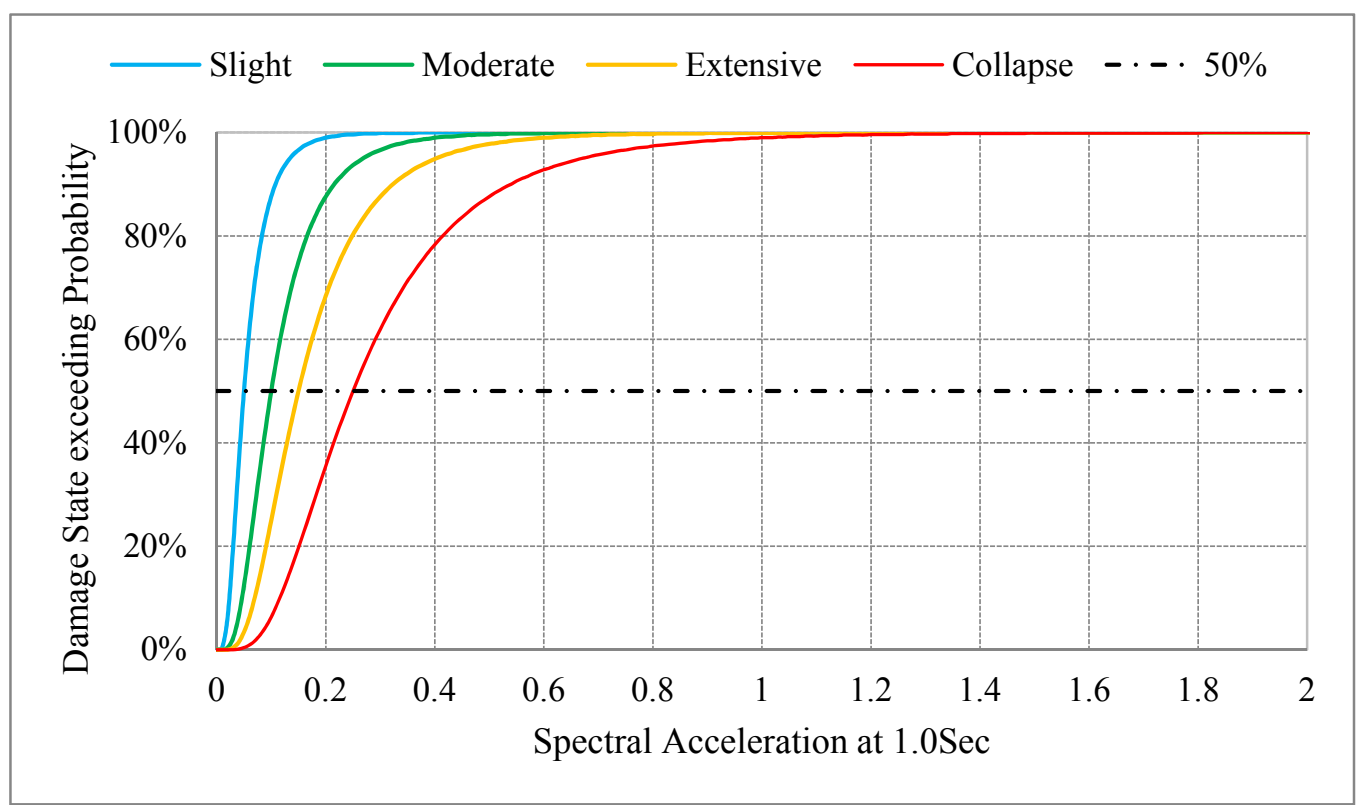

Figure 26: Aggregated fragility curve for I-40 crossing of Mississippi River. 
Cost Analysis by Varying Bridge Fragility by Route

Table 16: Cascadia Subduction Zone (CSZ) scenario event M9.0

\begin{tabular}{|c|c|c|c|c|c|c|c|}
\hline \multirow[b]{2}{*}{ Route } & \multirow[b]{2}{*}{ Fragility } & \multicolumn{6}{|c|}{ Damage states and Cost of entire network } \\
\hline & & slight & moderate & $\begin{array}{c}\text { Extensiv } \\
\mathrm{e}\end{array}$ & $\begin{array}{c}\text { Collaps } \\
\mathrm{e}\end{array}$ & $\begin{array}{c}\text { Repair } \\
\text { Cost }\end{array}$ & $\begin{array}{l}\text { Travel time } \\
\text { cost }\end{array}$ \\
\hline \multirow{2}{*}{$\begin{array}{c}\mathrm{I}-5 \\
(\mathrm{MWC}\end{array}$} & Existing & 164 & 106 & 64 & 6 & $\$ 1,080$ & $\$ 177$ \\
\hline & HWB4 & 160 & 105 & 64 & 6 & $\$ 1,073$ & $\$ 177$ \\
\hline ） & I-40 MRC & 160 & 190 & 76 & 6 & $\$ 29,536$ & $\$ 177$ \\
\hline \multirow{3}{*}{$\begin{array}{c}\mathrm{I}-5 \\
(\mathrm{MLL})\end{array}$} & Existing & 164 & 106 & 64 & 6 & $\$ 1,080$ & $\$ 177$ \\
\hline & HWB4 & 148 & 103 & 6 & 6 & $\$ 1,073$ & $\$ 177$ \\
\hline & $\mathrm{I}-40 \mathrm{MRC}$ & 148 & 106 & 280 & 7 & $\$ 2,620$ & $\$ 251$ \\
\hline \multirow{3}{*}{$\begin{array}{l}\mathrm{I}-5 \\
\text { (DJJ) }\end{array}$} & Existing & 164 & 106 & 64 & 6 & $\$ 1,080$ & $\$ 177$ \\
\hline & HWB4 & 137 & 106 & 64 & 6 & $\$ 1,073$ & $\$ 177$ \\
\hline & I-40 MRC & 137 & 163 & 191 & 6 & $\$ 2,235$ & $\$ 203$ \\
\hline \multirow[t]{3}{*}{$\mathrm{I}-84$} & Existing & 164 & 106 & 64 & 6 & $\$ 1,080$ & $\$ 177$ \\
\hline & HWB4 & 151 & 105 & 64 & 6 & $\$ 1,070$ & $\$ 177$ \\
\hline & $\mathrm{I}-40 \mathrm{MRC}$ & 205 & 166 & 65 & 6 & $\$ 1,262$ & $\$ 177$ \\
\hline \multirow[t]{3}{*}{ US 101} & Existing & 164 & 106 & 64 & 6 & $\$ 1,080$ & $\$ 177$ \\
\hline & HWB4 & 157 & 92 & 28 & 1 & $\$ 395$ & $\$ 48$ \\
\hline & $\mathrm{I}-40 \mathrm{MRC}$ & 157 & 92 & 28 & 144 & $\$ 2,397$ & $\$ 309$ \\
\hline \multirow[t]{3}{*}{ US 26} & Existing & 164 & 106 & 64 & 6 & $\$ 1,080$ & $\$ 177$ \\
\hline & HWB4 & 157 & 101 & 64 & 6 & $\$ 1,071$ & $\$ 177$ \\
\hline & $\mathrm{I}-40 \mathrm{MRC}$ & 163 & 124 & 95 & 22 & $\$ 1,482$ & $\$ 3,855$ \\
\hline \multirow[t]{3}{*}{ I 205} & Existing & 164 & 106 & 64 & 6 & $\$ 1,080$ & $\$ 177$ \\
\hline & HWB4 & 156 & 104 & 64 & 6 & $\$ 1,070$ & $\$ 177$ \\
\hline & I-40 MRC & 156 & 186 & 64 & 6 & $\$ 1,626$ & $\$ 177$ \\
\hline \multirow[t]{3}{*}{ I 405} & Existing & 164 & 106 & 64 & 6 & $\$ 1,080$ & $\$ 177$ \\
\hline & HWB4 & 157 & 106 & 64 & 6 & $\$ 1,079$ & $\$ 177$ \\
\hline & $\mathrm{I}-40 \mathrm{MRC}$ & 157 & 162 & 64 & 6 & $\$ 1,373$ & $\$ 177$ \\
\hline \multirow[t]{3}{*}{ US 30} & Existing & 164 & 106 & 64 & 6 & $\$ 1,080$ & $\$ 177$ \\
\hline & HWB4 & 159 & 104 & 62 & 6 & $\$ 1,054$ & $\$ 177$ \\
\hline & I-40 MRC & 160 & 107 & 81 & 16 & $\$ 1,470$ & $\$ 213$ \\
\hline \multirow[t]{3}{*}{ US 20} & Existing & 164 & 106 & 64 & 6 & $\$ 1,080$ & $\$ 177$ \\
\hline & HWB4 & 160 & 104 & 59 & 6 & $\$ 1,062$ & $\$ 162$ \\
\hline & $\mathrm{I}-40 \mathrm{MRC}$ & 160 & 104 & 59 & 28 & $\$ 1,224$ & $\$ 201$ \\
\hline \multirow[t]{3}{*}{ OR 38} & Existing & 164 & 106 & 64 & 6 & $\$ 1,080$ & $\$ 177$ \\
\hline & HWB4 & 161 & 104 & 63 & 6 & $\$ 1,071$ & $\$ 148$ \\
\hline & I-40 MRC & 161 & 104 & 72 & 15 & $\$ 1,171$ & $\$ 180$ \\
\hline \multirow[t]{3}{*}{ OR 42} & Existing & 164 & 106 & 64 & 6 & $\$ 1,080$ & $\$ 177$ \\
\hline & HWB4 & 160 & 93 & 51 & 5 & $\$ 922$ & $\$ 145$ \\
\hline & I-40 MRC & 160 & 93 & 60 & 50 & $\$ 1,365$ & $\$ 243$ \\
\hline
\end{tabular}


Table 17: Cascadia Subduction zone scenario event- North M8.3

\begin{tabular}{|c|c|c|c|c|c|c|c|}
\hline \multirow[b]{2}{*}{ Route } & \multirow[b]{2}{*}{ Fragility } & \multicolumn{6}{|c|}{ Damage states and Cost of entire network } \\
\hline & & slight & moderate & Extensive & Collapse & $\begin{array}{c}\text { Repair } \\
\text { Cost }\end{array}$ & $\begin{array}{c}\text { Travel time } \\
\text { cost }\end{array}$ \\
\hline \multirow{3}{*}{$\begin{array}{c}\mathrm{I}-5 \\
(\mathrm{MWC})\end{array}$} & Existing & 152 & 32 & 28 & 0 & $\$ 337$ & $\$ 8$ \\
\hline & HWB4 & 151 & 32 & 28 & 0 & $\$ 337$ & $\$ 8$ \\
\hline & $\mathrm{I}-40 \mathrm{MRC}$ & 151 & 129 & 28 & 0 & $\$ 28,479$ & $\$ 8$ \\
\hline \multirow{3}{*}{$\begin{array}{c}\mathrm{I}-5 \\
\text { (MLL) }\end{array}$} & Existing & 152 & 32 & 28 & 0 & $\$ 337$ & $\$ 8$ \\
\hline & HWB4 & 134 & 31 & 28 & 0 & $\$ 337$ & $\$ 8$ \\
\hline & $\mathrm{I}-40 \mathrm{MRC}$ & 134 & 231 & 49 & 0 & $\$ 818$ & $\$ 13$ \\
\hline \multirow{3}{*}{$\begin{array}{l}\mathrm{I}-5 \\
(\mathrm{DJJ})\end{array}$} & Existing & 152 & 32 & 28 & 0 & $\$ 337$ & $\$ 8$ \\
\hline & HWB4 & 149 & 32 & 28 & 0 & $\$ 337$ & $\$ 8$ \\
\hline & I-40 MRC & 210 & 92 & 40 & 0 & $\$ 590$ & $\$ 10$ \\
\hline \multirow[t]{3}{*}{ I-84 } & Existing & 152 & 32 & 28 & 0 & $\$ 337$ & $\$ 8$ \\
\hline & HWB4 & 144 & 32 & 28 & 0 & $\$ 334$ & $\$ 8$ \\
\hline & I-40 MRC & 190 & 80 & 28 & 0 & $\$ 473$ & $\$ 8$ \\
\hline \multirow[t]{3}{*}{ US 101} & Existing & 152 & 32 & 28 & 0 & $\$ 337$ & $\$ 8$ \\
\hline & HWB4 & 145 & 14 & 9 & 0 & $\$ 85$ & $\$ 3$ \\
\hline & I-40 MRC & 163 & 27 & 21 & 97 & $\$ 1,769$ & $\$ 155$ \\
\hline \multirow[t]{3}{*}{ US 26} & Existing & 152 & 32 & 28 & 0 & $\$ 337$ & $\$ 8$ \\
\hline & HWB4 & 143 & 32 & 28 & 0 & $\$ 335$ & $\$ 8$ \\
\hline & I-40 MRC & 150 & 66 & 49 & 12 & $\$ 613$ & $\$ 3,554$ \\
\hline \multirow[t]{3}{*}{ I 205} & Existing & 152 & 32 & 28 & 0 & $\$ 337$ & $\$ 8$ \\
\hline & HWB4 & 148 & 32 & 28 & 0 & $\$ 336$ & $\$ 8$ \\
\hline & I-40 MRC & 148 & 114 & 28 & 0 & $\$ 890$ & $\$ 8$ \\
\hline \multirow[t]{3}{*}{ I 405} & Existing & 152 & 32 & 28 & 0 & $\$ 337$ & $\$ 8$ \\
\hline & HWB4 & 152 & 32 & 28 & 0 & $\$ 337$ & $\$ 8$ \\
\hline & I-40 MRC & 152 & 88 & 28 & 0 & $\$ 630$ & $\$ 8$ \\
\hline \multirow[t]{3}{*}{ US 30} & Existing & 152 & 32 & 28 & 0 & $\$ 337$ & $\$ 8$ \\
\hline & HWB4 & 148 & 30 & 26 & 0 & $\$ 318$ & $\$ 8$ \\
\hline & I-40 MRC & 148 & 47 & 33 & 9 & $\$ 606$ & $\$ 66$ \\
\hline \multirow[t]{3}{*}{ US 20} & Existing & 152 & 32 & 28 & 0 & $\$ 337$ & $\$ 8$ \\
\hline & HWB4 & 150 & 30 & 24 & 0 & $\$ 323$ & $\$ 8$ \\
\hline & $\mathrm{I}-40 \mathrm{MRC}$ & 150 & 30 & 24 & 22 & $\$ 485$ & $\$ 77$ \\
\hline \multirow[t]{3}{*}{ OR 38} & Existing & 152 & 32 & 28 & 0 & $\$ 337$ & $\$ 8$ \\
\hline & HWB4 & 148 & 32 & 28 & 0 & $\$ 336$ & $\$ 8$ \\
\hline & I-40 MRC & 148 & 39 & 30 & 0 & $\$ 409$ & $\$ 10$ \\
\hline \multirow[t]{3}{*}{ OR 42} & Existing & 152 & 32 & 28 & 0 & $\$ 337$ & $\$ 8$ \\
\hline & HWB4 & 148 & 31 & 28 & 0 & $\$ 332$ & $\$ 8$ \\
\hline & I-40 MRC & 148 & 85 & 28 & 0 & $\$ 443$ & $\$ 8$ \\
\hline
\end{tabular}


Table 18: Cascadia Subduction zone scenario event- South M8.3

\begin{tabular}{|c|c|c|c|c|c|c|c|}
\hline \multirow[b]{2}{*}{ Route } & \multirow[b]{2}{*}{ Fragility } & \multicolumn{6}{|c|}{ Damage states and Cost of entire network } \\
\hline & & slight & moderate & $\begin{array}{c}\text { Extensiv } \\
\mathrm{e}\end{array}$ & $\begin{array}{c}\text { Collaps } \\
\mathrm{e}\end{array}$ & $\begin{array}{c}\text { Repair } \\
\text { Cost }\end{array}$ & $\begin{array}{l}\text { Travel time } \\
\text { cost }\end{array}$ \\
\hline \multirow{3}{*}{$\begin{array}{c}\mathrm{I}-5 \\
(\mathrm{MWC} \\
)\end{array}$} & Existing & 123 & 33 & 23 & 2 & $\$ 364$ & $\$ 94$ \\
\hline & HWB4 & 123 & 33 & 23 & 2 & $\$ 364$ & $\$ 94$ \\
\hline & I-40 MRC & 220 & 33 & 23 & 2 & $\$ 3,741$ & $\$ 94$ \\
\hline \multirow{3}{*}{$\begin{array}{c}\mathrm{I}-5 \\
(\mathrm{MLL})\end{array}$} & Existing & 123 & 33 & 23 & 2 & $\$ 364$ & $\$ 94$ \\
\hline & HWB4 & 105 & 32 & 23 & 2 & $\$ 359$ & $\$ 94$ \\
\hline & $\mathrm{I}-40 \mathrm{MRC}$ & 113 & 245 & 23 & 2 & $\$ 739$ & $\$ 94$ \\
\hline \multirow{3}{*}{$\begin{array}{l}\mathrm{I}-5 \\
\text { (DJJ) }\end{array}$} & Existing & 123 & 33 & 23 & 2 & $\$ 364$ & $\$ 94$ \\
\hline & HWB4 & 103 & 33 & 23 & 2 & $\$ 360$ & $\$ 94$ \\
\hline & I-40 MRC & 104 & 175 & 64 & 2 & $\$ 998$ & $\$ 104$ \\
\hline \multirow[t]{3}{*}{$\mathrm{I}-84$} & Existing & 123 & 33 & 23 & 2 & $\$ 364$ & $\$ 94$ \\
\hline & HWB4 & 123 & 33 & 23 & 2 & $\$ 364$ & $\$ 94$ \\
\hline & I-40 MRC & 167 & 33 & 23 & 2 & $\$ 378$ & $\$ 94$ \\
\hline \multirow[t]{3}{*}{ US 101} & Existing & 123 & 33 & 23 & 2 & $\$ 364$ & $\$ 94$ \\
\hline & HWB4 & 116 & 17 & 12 & 1 & $\$ 157$ & $\$ 33$ \\
\hline & $\mathrm{I}-40 \mathrm{MRC}$ & 142 & 55 & 17 & 69 & $\$ 1,247$ & $\$ 194$ \\
\hline \multirow[t]{3}{*}{ US 26} & Existing & 123 & 33 & 23 & 2 & $\$ 364$ & $\$ 94$ \\
\hline & HWB4 & 123 & 33 & 23 & 2 & $\$ 364$ & $\$ 94$ \\
\hline & $\mathrm{I}-40 \mathrm{MRC}$ & 190 & 33 & 23 & 2 & $\$ 381$ & $\$ 94$ \\
\hline \multirow[t]{3}{*}{ I 205} & Existing & 123 & 33 & 23 & 2 & $\$ 364$ & $\$ 94$ \\
\hline & HWB4 & 123 & 33 & 23 & 2 & $\$ 364$ & $\$ 94$ \\
\hline & I-40 MRC & 203 & 33 & 23 & 2 & $\$ 430$ & $\$ 94$ \\
\hline \multirow[t]{3}{*}{ I 405} & Existing & 123 & 33 & 23 & 2 & $\$ 364$ & $\$ 94$ \\
\hline & HWB4 & 123 & 33 & 23 & 2 & $\$ 364$ & $\$ 94$ \\
\hline & I-40 MRC & 179 & 33 & 23 & 2 & $\$ 399$ & $\$ 94$ \\
\hline \multirow[t]{3}{*}{ US 30} & Existing & 123 & 33 & 23 & 2 & $\$ 364$ & $\$ 94$ \\
\hline & HWB4 & 123 & 33 & 23 & 2 & $\$ 364$ & $\$ 94$ \\
\hline & I-40 MRC & 138 & 33 & 23 & 2 & $\$ 370$ & $\$ 94$ \\
\hline \multirow[t]{3}{*}{ US 20} & Existing & 123 & 33 & 23 & 2 & $\$ 364$ & $\$ 94$ \\
\hline & HWB4 & 116 & 17 & 12 & 1 & $\$ 157$ & $\$ 33$ \\
\hline & I-40 MRC & 116 & 43 & 45 & 2 & $\$ 461$ & $\$ 98$ \\
\hline \multirow[t]{3}{*}{ OR 38} & Existing & 123 & 33 & 23 & 2 & $\$ 364$ & $\$ 94$ \\
\hline & HWB4 & 121 & 32 & 22 & 2 & $\$ 357$ & $\$ 76$ \\
\hline & I-40 MRC & 121 & 36 & 30 & 8 & $\$ 437$ & $\$ 95$ \\
\hline \multirow[t]{3}{*}{ OR 42} & Existing & 123 & 33 & 23 & 2 & $\$ 364$ & $\$ 94$ \\
\hline & HWB4 & 114 & 23 & 13 & 1 & $\$ 246$ & $\$ 73$ \\
\hline & I-40 MRC & 114 & 23 & 24 & 44 & $\$ 688$ & $\$ 106$ \\
\hline
\end{tabular}


Table 19: Portland Hills scenario event- South M6.5

\begin{tabular}{|c|c|c|c|c|c|c|c|}
\hline \multirow[b]{2}{*}{ Route } & \multirow[b]{2}{*}{ Fragility } & \multicolumn{6}{|c|}{ Damage states and Cost of entire network } \\
\hline & & slight & moderate & Extensive & Collapse & $\begin{array}{c}\text { Repair } \\
\text { Cost }\end{array}$ & $\begin{array}{c}\text { Travel time } \\
\text { cost }\end{array}$ \\
\hline \multirow{3}{*}{$\begin{array}{c}\mathrm{I}-5 \\
(\mathrm{MWC})\end{array}$} & Existing & 27 & 41 & 48 & 5 & $\$ 1,573$ & $\$ 68$ \\
\hline & HWB4 & 19 & 29 & 38 & 4 & $\$ 1,090$ & $\$ 68$ \\
\hline & I-40 MRC & 19 & 40 & 54 & 74 & $\$ 113,529$ & $\$ 96$ \\
\hline \multirow{3}{*}{$\begin{array}{c}\mathrm{I}-5 \\
(\mathrm{MLL})\end{array}$} & Existing & 27 & 41 & 48 & 5 & $\$ 1,573$ & $\$ 68$ \\
\hline & HWB4 & 27 & 41 & 48 & 5 & $\$ 1,573$ & $\$ 68$ \\
\hline & $\mathrm{I}-40 \mathrm{MRC}$ & 46 & 49 & 48 & 5 & $\$ 1,593$ & $\$ 68$ \\
\hline \multirow{3}{*}{$\begin{array}{l}\mathrm{I}-5 \\
\text { (DJJ) }\end{array}$} & Existing & 27 & 41 & 48 & 5 & $\$ 1,573$ & $\$ 68$ \\
\hline & HWB4 & 27 & 41 & 48 & 5 & $\$ 1,573$ & $\$ 68$ \\
\hline & I-40 MRC & 27 & 41 & 48 & 5 & $\$ 1,573$ & $\$ 68$ \\
\hline \multirow[t]{3}{*}{ I- 84} & Existing & 27 & 41 & 48 & 5 & $\$ 1,573$ & $\$ 68$ \\
\hline & HWB4 & 26 & 37 & 38 & 4 & $\$ 1,090$ & $\$ 68$ \\
\hline & $\mathrm{I}-40 \mathrm{MRC}$ & 37 & 53 & 49 & 23 & $\$ 1,816$ & $\$ 70$ \\
\hline \multirow[t]{3}{*}{ US 101} & Existing & 27 & 41 & 48 & 5 & $\$ 1,573$ & $\$ 68$ \\
\hline & HWB4 & 27 & 41 & 48 & 5 & $\$ 1,573$ & $\$ 68$ \\
\hline & I-40 MRC & 33 & 41 & 48 & 5 & $\$ 1,574$ & $\$ 68$ \\
\hline \multirow[t]{3}{*}{ US 26} & Existing & 27 & 41 & 48 & 5 & $\$ 1,573$ & $\$ 68$ \\
\hline & HWB4 & 24 & 38 & 41 & 5 & $\$ 1,510$ & $\$ 61$ \\
\hline & $\mathrm{I}-40 \mathrm{MRC}$ & 28 & 45 & 48 & 42 & $\$ 1,981$ & $\$ 104$ \\
\hline \multirow[t]{3}{*}{ I 205} & Existing & 27 & 41 & 48 & 5 & $\$ 1,573$ & $\$ 68$ \\
\hline & HWB4 & 22 & 37 & 48 & 5 & $\$ 1,560$ & $\$ 68$ \\
\hline & $\mathrm{I}-40 \mathrm{MRC}$ & 22 & 55 & 112 & 5 & $\$ 3,506$ & $\$ 77$ \\
\hline \multirow[t]{3}{*}{ I 405} & Existing & 27 & 41 & 48 & 5 & $\$ 1,573$ & $\$ 68$ \\
\hline & HWB4 & 24 & 29 & 39 & 3 & $\$ 1,080$ & $\$ 64$ \\
\hline & $\mathrm{I}-40 \mathrm{MRC}$ & 24 & 29 & 39 & 59 & $\$ 2,255$ & $\$ 76$ \\
\hline \multirow[t]{3}{*}{ US 30} & Existing & 27 & 41 & 48 & 5 & $\$ 1,573$ & $\$ 68$ \\
\hline & HWB4 & 26 & 41 & 47 & 4 & $\$ 1,452$ & $\$ 66$ \\
\hline & $\mathrm{I}-40 \mathrm{MRC}$ & 31 & 43 & 53 & 11 & $\$ 1,655$ & $\$ 149$ \\
\hline \multirow[t]{3}{*}{ US 20} & Existing & 27 & 41 & 48 & 5 & $\$ 1,573$ & $\$ 68$ \\
\hline & HWB4 & 27 & 41 & 48 & 5 & $\$ 1,573$ & $\$ 68$ \\
\hline & $\mathrm{I}-40 \mathrm{MRC}$ & 27 & 41 & 48 & 5 & $\$ 1,573$ & $\$ 68$ \\
\hline \multirow[t]{3}{*}{ OR 38} & Existing & 27 & 41 & 48 & 5 & $\$ 1,573$ & $\$ 68$ \\
\hline & HWB4 & 27 & 41 & 48 & 5 & $\$ 1,573$ & $\$ 68$ \\
\hline & I-40 MRC & 27 & 41 & 48 & 5 & $\$ 1,573$ & $\$ 68$ \\
\hline \multirow[t]{3}{*}{ OR 42} & Existing & 27 & 41 & 48 & 5 & $\$ 1,573$ & $\$ 68$ \\
\hline & HWB4 & 27 & 41 & 48 & 5 & $\$ 1,573$ & $\$ 68$ \\
\hline & $\mathrm{I}-40 \mathrm{MRC}$ & 27 & 41 & 48 & 5 & $\$ 1,573$ & $\$ 68$ \\
\hline
\end{tabular}


Travel time cost for I-5 northern segment (from Multnomah County to Clackamas County) is not affected when the fragility of the route was varied between two extremes cases. For a very weak fragility, there were a lot more slightly damaged bridges which would become operational after an event. This would be the reason why the travel time related losses are not significant. However, altering fragility of US-101 showed the highest variation in both repair-replacement cost and travel time related losses. There are a lot of extensive and complete collapse cases on this route and that would cause a major disruption in system performance. However, in the prioritization attempt, other factors, such as average daily traffic, length of segment were considered. The following chapter gives the algorithm employed. From the above results it can be seen that, highways routes that are least redundant are going to disrupt the system performance. 


\subsection{VULNERABILITY OF EXISTING NETWORK AND RECOMMENDATION FOR BRIDGE RETROFIT}

\subsection{VULNERABILITY OF OREGON HIGHWAY NETWORK}

With a majority of state owned bridges designed and built between 1950 and 1980, the state of Oregon would face a devastating post earthquake situation if a major event occurred in the state. Even though retrofitting all vulnerable bridges in the near future might not be feasible, we can find ways to start moving in that direction. Therefore, the prioritization process of major highway segments, or key individual bridges, that are vulnerable under seismic loading will be important and necessary (ODOT 2009).

In order to estimate the economic loss of the major highway routes, all the earthquake scenarios considered were given similar chance of occurrence in the near future and the maximum cost incurred was considered for each highway segment. The economic losses include repair or replacement cost of bridges and the cost associated with travel time losses. These costs will be an important factor in determining the priority of each segment to be retrofitted. Retrofit cost is divided into two phases - Phase I and Phase II. Phase I retrofit includes replacing unstable bearings with stable bearings, providing additional seat width, limit movement of girders parallel to roadway using restrainers and limit movement of girders perpendicular to roadway using shear lugs. The main goal of Phase I retrofitting is "life safety." This is accomplished with retrofit details designed to prevent the superstructure from separating from the substructure and thereby preventing collapse of a span. Phase I retrofit is effective for moderate earthquakes. Phase II retrofit includes strengthening the substructure elements. The major goal of Phase II retrofitting is also "life safety" but for maximum anticipated earthquake. Equation 2 shows how these values are calculated. Using those cost estimates, the inventory replacement value of over 1900 bridges that are part of the Oregon State Highways system is about \$21 billion. Phase I retrofit cost is a little over $\$ 1$ billion and Phase II retrofit cost is about $\$ 3$ billion.

Equation 2:

Retrofit Cost (Phase I) $=\$ 35 / \mathrm{ft}^{2} \mathrm{x}$ the deck area

Retrofit Cost $\left(\right.$ Phase II) $=\$ 90 / \mathrm{ft}^{2} \mathrm{x}$ the deck area

Table 20 gives a breakdown of the distribution and replacement and retrofit cost of the bridges along the major highway routes. 
Table 20: Replacement cost of state highway bridges on selected routes in millions.

\begin{tabular}{|c|c|c|c|c|}
\hline \multirow{2}{*}{ Route } & No of Bridges & $\begin{array}{c}\text { Replacement } \\
\text { Cost } \\
\text { (in millions) }\end{array}$ & \multicolumn{2}{|c|}{ Retrofit cost( in millions) } \\
\cline { 3 - 5 } & & $\$ 2,310$ & $\$ 130$ & $\$ 330$ \\
I-5 (MWC) & 97 & $\$ 765$ & $\$ 41$ & $\$ 105$ \\
I-5 (MLL) & 221 & $\$ 840$ & $\$ 45$ & $\$ 115$ \\
I-5 (DJJ) & 184 & $\$ 920$ & $\$ 50$ & $\$ 130$ \\
I-84 & 200 & $\$ 1,430$ & $\$ 80$ & $\$ 200$ \\
US-101 & 143 & $\$ 660$ & $\$ 35$ & $\$ 90$ \\
US-26 & 76 & $\$ 2,150$ & $\$ 120$ & $\$ 300$ \\
I-205 & 82 & $\$ 1,175$ & $\$ 65$ & $\$ 165$ \\
I-405 & 56 & $\$ 160$ & $\$ 8$ & $\$ 20$ \\
US-30 & 38 & $\$ 400$ & $\$ 20$ & $\$ 55$ \\
US-20 & 32 & $\$ 100$ & $\$ 5$ & $\$ 13$ \\
OR-38 & 18 & $\$ 120$ & $\$ 6$ & $\$ 17$ \\
OR-42 & 54 & & & \\
\hline
\end{tabular}

Approach for route retrofit selection strategy was based on "cost vs. benefit." The retrofit cost of considered routes is first estimated. Then the benefit of retrofitting each route is estimated by altering bridge fragility and re-running analysis. Of the major highway routes that were considered, US 101, OR 42, US 20 and OR 38 are the ones that showed an increase in travel time related losses. When the routes were replaced with stronger bridges the cost went down for repair/replacement and an even significant decrease in travel time loss. But because financial constraint is a major deciding aspect, retrofit cost and the cost implication of bridge replacement or repair are taken into account together with other factors such as traffic volume on route and length of route were also considered. Though improving longer stretches of highways with lower costs would be a key criterion in prioritizing the system, attention should be given to most populated areas of our state (e.g. I-5 North). ODOT, in their November 2009 report titled Seismic Vulnerability of Oregon State Highway Bridges, has considered both the Route Length and the Average Daily Traffic to be very important factors in their retrofit prioritization process. And similar approach is taken in this case as well.

Table 21 gives the results of the algorithm. I-405 is the route that is of highest priority. Even though I-405 is a short length highway, that route however has the third highest average daily traffic compared to the other routes. And most importantly, the cost of repairing damaged bridges if a major earthquake occurs more than three times the amount estimated to retrofit all bridges in the route. Same principle was followed when ranking the rest of the routes.

These results are only intended to reflect the vulnerability of the highway network and what precautions could be taken to be better prepared. Earthquakes, in addition to damaging the roadway system, can also damage buildings, contents, and lifeline infrastructure which are not considered to be part of this highway bridge vulnerability study. 


\subsection{ADVANTAGES OF RETROFITTING}

Identification of structures in most need of retrofitting is not an easy task because we first need to be able to identify the hazard, analyze the vulnerability of selected priority structures to that hazard, and then fix those structures. And the cost of retrofitting must be balanced against risk which makes the decision even harder.

Benefit of retrofit can be computed as the value loss that can be avoided or reduced. The value loss criteria includes bridge damage, property loss, causalities and the traffic disruption that can be caused that can be avoided. Retrofitting can be very expensive and the decision to retrofit depends on political, social, and economic factors as well as engineering issues. Retrofit cost can be computed in present values as equal to the total future economic losses avoided from social cost and repair/restoration cost over the remaining bridge service lives. Estimated benefit is compared with the retrofit cost to investigate the benefit-cost ratio (Zhou 2009).

It is impossible to design or retrofit a structure to be "earthquake proof" to be totally safe near the epicenter of a large quake but structures should be designed or retrofitted for "life safety". Common sense and engineering judgment will be necessary in weighing the actual costs and benefits of retrofitting, against the risks of doing nothing. Also, the effect on the entire highway system must be kept in mind. The priority ranking given on Table 21 shall only be taken as a preliminary ranking. These routes need to be examined more and an advanced cost-benefit investigations should be conducted before decisions are made. 


\begin{tabular}{|c|c|c|c|}
\hline & 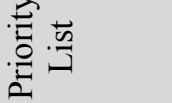 & \multicolumn{2}{|l|}{$-a m+n o r \infty a g=\geq$} \\
\hline & 誉言 & \multicolumn{2}{|l|}{ 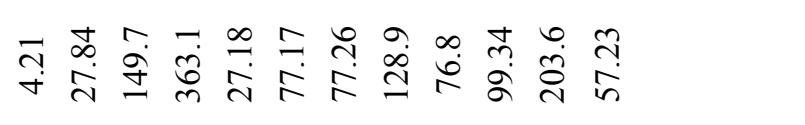 } \\
\hline & 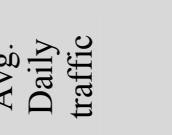 & \multicolumn{2}{|l|}{ 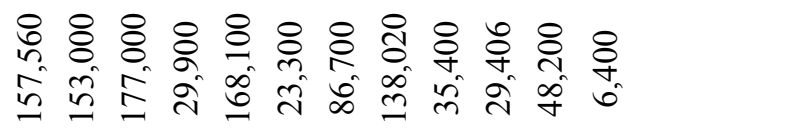 } \\
\hline \multicolumn{2}{|c|}{ 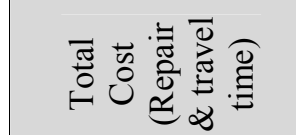 } & \multicolumn{2}{|l|}{ 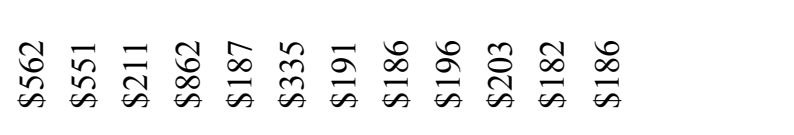 } \\
\hline \multirow{2}{*}{ 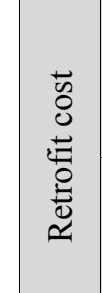 } & 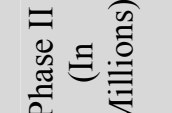 & \multicolumn{2}{|l|}{ 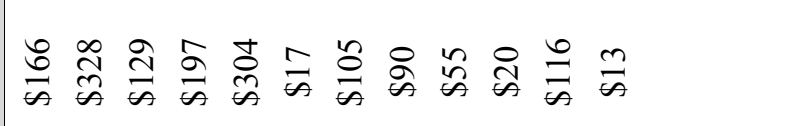 } \\
\hline & & \multicolumn{2}{|l|}{ 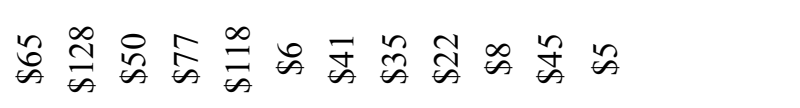 } \\
\hline 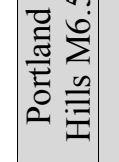 & $\begin{array}{cl} & \\
& \end{array}$ & 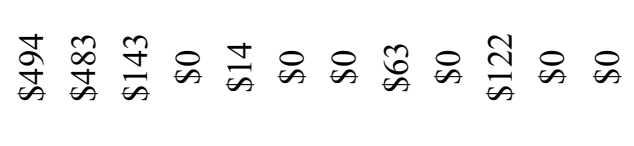 & $\stackrel{\infty}{\leftrightarrow}$ \\
\hline 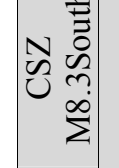 & 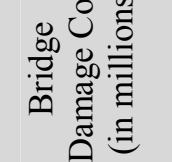 & 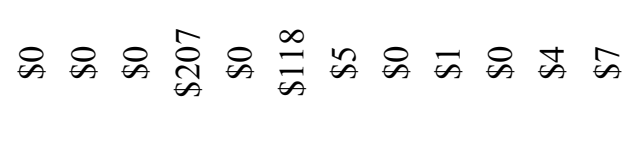 & $\stackrel{t}{a}$ \\
\hline 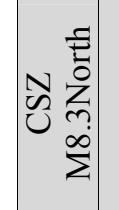 & 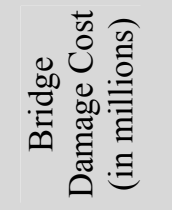 & 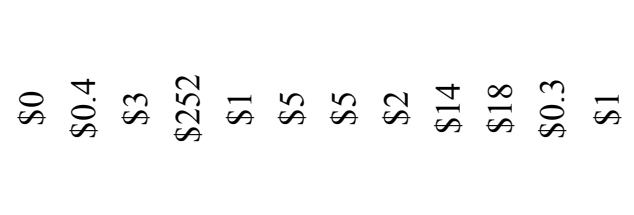 & $\stackrel{\infty}{\infty}$ \\
\hline 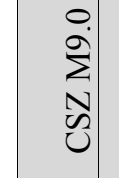 & 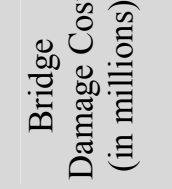 & 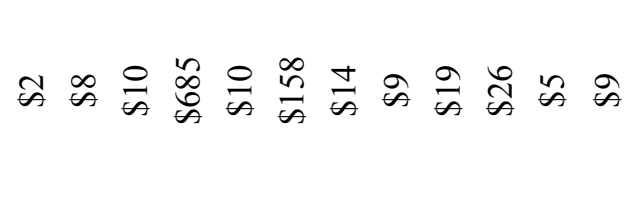 & $\stackrel{Ð}{\infty}$ \\
\hline & 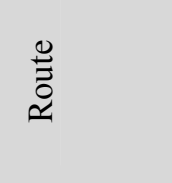 & 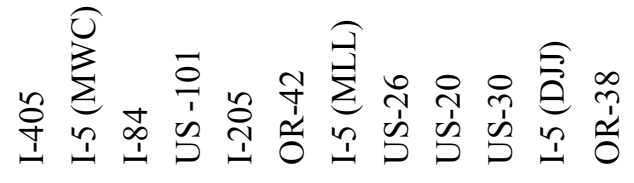 & \\
\hline
\end{tabular}




\subsection{CONCLUDING REMARKS}

\subsection{SUMMARY}

\subsubsection{Earthquake Impacts on Highways}

Bridges represent vulnerability points within a transportation network. Hence, damaged bridges will have a great impact on the system performance causing severe traffic congestion statewide. This disruption of traffic flow will in turn impact post-earthquake emergency response, repair and reconstruction operations.

Earthquake damage to multiple bridges would disable entire routes for up to three to six months and severe traffic congestion will occur for at least a year. Movement of goods to final destinations - for example, manufacturers, retail outlets, and hospitals - will be much slower for a long period of time. This will have long term economic consequences due to the valued loss of time when commuter and freight travel slows down due to the disrupted network. A commute to work that took 30 minutes could take hours; and businesses will suffer due to this disruption and may even move away from Oregon elsewhere.

In the scenarios considered, highways I-5, I-84, US-101, I-405, US-26, US-20, US-30, OR-38, and OR-42 have extensive damage or collapse. Other bridges, such as those owned by county or city are not currently incorporated into the model are also likely to experience damage. Failure of the roadways access due to other earthquake related effects including potential landslides and liquefaction were also not considered part of the scenario analyses.

\subsubsection{Recovery Issues}

Single bridges on some major routes may be replaced with in a year. However, it will probably take over 5 years to replace $70+$ bridges due to limited resources. Another challenge is redirecting up to 150,000 cars per day (I-5) onto surface streets and that some streets cannot carry the increased traffic volumes that could possibly be diverted to them. And simultaneous route outages could bring traffic to a standstill, with few substitutes to carry daily traffic.

\subsubsection{Analysis results and interpretation}

Damage states of bridges are computed by first computing the bridge's demand spectral acceleration for a given scenario earthquake, it is then compared to each bridge's spectral acceleration capacity that leads to the onset of each damage state. However, these median values of ground motion computed do not necessarily represent the exact levels of ground shaking at the bridge locations since the exact levels of ground shaking of an earthquake will not be known without actually recording the motion with strong motion accelerators at the time of the event. Consequently, there is a probability that some bridges might perform better or worse during a real earthquake compared to a scenario analysis. 
Previously developed analytical fragility curves are based on simplified models and simplified methodologies, which by their very nature include a significant amount of uncertainty, and therefore do not completely represent the performance of most bridges. To adequately represent the fragility of a bridge and to improve the reliability and effectiveness of seismic Risk assessment tools, improved fragility curves for highway bridges are needed.

In addition, fragility values are based on probabilistic median expected performances. A particular bridge that had a specific damage state may not exactly correlate to actual events but is more representative as the expected damage state. For these reasons, the aggregate response over the route should be examined and is more informative than considering the damage state of an individual bridge.

Furthermore, other devastating effects of earthquakes, such as potential landslides and liquefaction, are not included in these results. These analyses should be done outside or REDARS2 since REDARS2 doesn't have the capability of analyzing damaged caused due to landslides and the results from liquefaction are not well represented.

\subsection{SUMMARY OF ISSUES ENCOUNTERED IN REDARS2}

Implementing REDARS2 presents challenges. Following are some of the problems that were encountered

- Data needed were not easily accessible and often needed to be re-formatted.

- Even after large soil data collection, liquefaction assessment was not well represented.

- Use of "Import Wizard" is challenging and limiting for incorporating state wide size models and networks created from sources other than NHPMS.

- Bridge data needed to be manually defined as the import mechanism often left out bridges from the highways segment definitions

- Errors in bridge replacement cost estimation are inherent within the analyses and need to be post-processed.

- Inconsistent skew angle definitions and implementation was found in the NBI.

In all, rigorous input data validation process is needed when constructing REDARS2 models before analyses can be initiated. The input data validation was conducted in this study based on data obtained from Oregon DOT.

\subsection{SUGGESTION FOR FUTURE RESEARCH}

The work in the present study should be extended through additional research in the following areas: 
- Develop improved fragility curves adequately represent the fragility of a bridge and to improve the reliability and effectiveness of seismic risk assessment tools, improved fragility curves for Oregon highway bridges are needed.

- Methodologies for the incorporation of liquefaction and ground deformation hazards should be developed to combine with the results of this study for a more comprehensive prioritization assessment. 


\subsection{REFERENCES}

US Geological Survey. Advanced National Seismic System (ANSS), ShakeMap, Global Region, Maps of ground shaking and intensity for event Portland_Hills6.5_se, Portland Hills M6.5 Scenario. 06 04, 2009. <http://earthquake.usgs.gov/Earthquakecenter/shakemap>. Abrahamson, N.A., and W.L. Silva. "Empirical Response Spectral Attenuation Relations for Shallow Crustal Earthquakes." Seismological Research Letters 68, no. 1 (January/ February 1997): 94-127.

Atwater, B. F. "Evidence for great Holocene earthquakes along the outer coast of Washington state." Science 236 (1987): 942-944.

Basoz, N., Mander, J. "Enhancement of the Highway Transportation Lifeline Module in HAZUS." National Institute of Building Sciences, 1999.

Brennan, P. "Background Brief on Bridges." Oregon Legislative Committee Services, 2004.

Chang, S. E., S. A. Seligson, and R.T. Eguchi. Estimation of the Economic Impact of Multiple Lifeline Disruption. NCEER Bulletine, NCEER, 1996.

Cho, S., S. Ghosh, C.K. Huyck, and S.D. Werner. "User Manual and Technical Documentation for the REDARS2TM Import Wizard." ImageCat, Inc, 2006.

Council on Disaster Reduction and the Technical Council on Lifeline Earthquake Engineering of ASCE. Acceptable Risk Processes: Lifelines and Natural Hazards. Edited by C. E. Taylor and E Vanmarcke. ASCE, 2002.

Daykin, C. D., T. Pentikainen, and M. Pesonen. Practical Risk Theory for Actuaries. London: Chapman \& Hall., 1994.

Dusicka, P., Glickman, M., Oppenheimer, H. "Experiences in Creating a Seismic Risk Model of the Oregon Highway Bridge Network Using REDARS2." 6th National Seismic Conference on Bridges and Highways. Charleston, SC: MCEER, 2008. 
Enke, D., C. Tirasirichai, and R., Luna. "Estimation of Earthquake Loss due to Bridge Damage in the St. Louis Metropolitan Area: Part II - Indirect Losses." Natural Hazards Review (ASCE) 9, no. 1 (2008): 12-19.

FEMA. "HAZUS®MH MR4 Earthquake Model Technical Manual." Washington, DC: Federal Emergency Management Agency, 2003.

—. "HAZUS99-SR2 Earthquake Loss Estimation Technical Manual." Washington, DC: Federal Emergency Management Agency, 2002.

Frankel, A.D., et al. Documentation for the 2002 Update of the National Seismic Hazard Maps. Open-File Report 02-420, Denver, CO: U. S. Department of the Interior, U. S. Geological Survey, 2002.

King, S. A., Kiremidjian, A. S., Basoz, N., Law, K., Vucetic, M., Doroudian, M., R. A. Olson, J. M. Eidinger, K. A. Goettel, and G. Horner. "Methodologies for Evaluating the Socio-Economic Consequences of Large Earthquakes." 1997.

Kiremidjian, A. S., Y. Fan, A. Hortacsu, K. Burnell, and J. LeGrue. "Earthquake risk assessment for transportation systems: Analysis of pre-retrofitted system." 7th National Conference on Earthquake Engineering . Boston: EERI, 2002.

Madin, I. P., G. R. Priest, M. A. Mabey, S. Malone, T. Yelin, and D., Meier. "March 23, 1993, Scotts Mills earth-quake - western Oregon's wake-up call." Oregon Geology 55, no. 3 (1993): $51-57$.

Nielson, Bryant G. "Analytical Fragility Curves for Highway Bridges in Moderate Seismic Zones." School of Civil and Environmental Engineering, Georgia Institute of Technology, 2005.

Nielson, Bryant G., and Reginald DesRoches. "Analytical Seismic Fragility Curves for Typical Bridges in the Central and Southeastern United States." Earthquake Spectra (Earthquake Engineering Research Institute) 23, no. 3 (August 2007): 615-633.

ODOT. "Seismic Vulnerability Assessment of Oregon Highway Bridges: Mitigation Strategies to reduce major mobility risks." Salem, OR, 2009. 
Oregon Department of Transportation. Seismic Vulnerability of Oregon State Highway Bridges: Mitigation Strategies To Reduce Major Mobility Risks. Salem: ODOT, 2009.

Roberts, J. "Recent Advances in Seismic Design and Retrofit of California Bridges\|, Lifeline Earthquake Engineering." Proceedings of the Third U.S. Conference. ASCE, 1991. 52-74.

Soil Survey Staff, Natural Resources Conservation Service, United States Department of Agriculture. Web Soil Survey. 02 2010. http://websoilsurvey.nrcs.usda.gov/ (accessed 02 2010). Stevanovic, A., and P. Nadimpalli. Seismic Vulnerability and Emergency Response Analyses of UDOT Lifelines. Department of Civil \& Environmental Engineering, University of Utah, 2010. Tokimatsu, K., and H B, Seed. "Evaluation of Settlements in Sands due to Earthquake Shaking." Journal of the Geotechnical Engineering Division (ASCE) 113, no. 8 (August 1987): 861-878.

U.S. Department of Transportation Federal Highway Administration. Recording and Coding Guide for the Structure Inventory and Appraisal of the Nation's Bridges. Report No FHWAPD-96-001, Office of Engineering Bridge Division, Washington, D.C., FHWA, 1995.

US Geological Survey. Advanced National Seismic System (ANSS), ShakeMap, Global Region, Maps of ground shaking and intensity. 07 16, 2009.

$<$ http://earthquake.usgs.gov/Earthquakecenter/shakemap $>$.

-. Advanced National Seismic System (ANSS), ShakeMap, Global Region, Maps of ground shaking and intensity for event Casc_North8.3_se, Cascadia North M8.3 Scenario. 06 04, 2009. <http://earthquake.usgs.gov/Earthquakecenter/shakemap>.

-. Advanced National Seismic System (ANSS), ShakeMap, Global Region, Maps of ground shaking and intensity for event Klamath_Falls6.5_se, Klamath Falls M6.5 Scenario. 0604 , 2009. <http://earthquake.usgs.gov/Earthquakecenter/shakemap >.

-. Advanced National Seismic System (ANSS), ShakeMap, Global Region, Maps of ground shaking and intensity for event Portland_Hills_Fault_se, Portland Hills Fault Scenario. 0101 , 2009. <http://earthquake.usgs.gov/Earthquakecenter/shakemap>.

Werner, S. D., et al. Technical Manual: REDARS2 2 Methodology and Software for Seismic Risk Analysis of Highway Systems. Oakland, 2006. 
Wiley, T. J., Sherrod, D. R., Keefer, D. K., Qamar, A., Schuster, R. L., Dewey, J. W., Mabey, M. A., Black, G. L., and Wells, R. E. "Klamath Falls Earthquake, September 20, 1993 — Including the strongest quake ever measured in Oregon." Oregon Geology 55, no. 6 (1993): $127-134$.

Yamaguchi, D. K., Atwater, B. F., Bunker, D. E., Benson, B. E., and Reid, M. S. "Tree-ring dating the 1700 Cascadia earthquake." Nature 389 (1997): 922.

Yaney, P. "Shake, Rattle, Seattle." The New York Times. 03 27, 2010.

http://www.nytimes.com/2010/03/28/opinion/28yanev.html.

Zhou, Y., Banerjee, S. and Shinozuka, M. Socio-economic effect of seismic retrofit of bridges for highway transportation networks: a pilot study. Irvine, CA: Department of Civil and Environmental Engineering, University of California, Irvine, 2009. 


\subsection{APPENDICES}

\subsection{APPENDIX A - HIGHWAY SYSTEM CLASSIFICATION}

Table A. 1: Highway System Classification (HAZUS-MH MR4 Technical Manual 2009)

\begin{tabular}{|l|l|}
\hline Label & Description \\
\hline HWB1 & Major Bridge - Length $>150$ m (Conventional Design) \\
\hline HWB2 & Major Bridge - Length > 150m (Seismic Design) \\
\hline HWB3 & Single Span - (Not HWB1 or HWB2) (Conventional Design) \\
\hline HWB4 & Single Span - (Not HWB1 or HWB2) (Seismic Design) \\
\hline HWB5 & Concrete, Multi-Column Bent, Simple Support (Conventional Design), Non-California (Non-CA) \\
\hline HWB6 & Concrete, Multi-Column Bent, Simple Support (Conventional Design), California (CA) \\
\hline HWB7 & Concrete, Multi-Column Bent, Simple Support (Seismic Design) \\
\hline HWB8 & Continuous Concrete, Single Column, Box Girder (Conventional Design) \\
\hline HWB9 & Continuous Concrete, Single Column, Box Girder (Seismic Design) \\
\hline HWB10 & Continuous Concrete, (Not HWB8 or HWB9) (Conventional Design) \\
\hline HWB11 & Continuous Concrete, (Not HWB8 or HWB9) (Seismic Design) \\
\hline HWB12 & Steel, Multi-Column Bent, Simple Support (Conventional Design), Non-California (Non-CA) \\
\hline HWB13 & Steel, Multi-Column Bent, Simple Support (Conventional Design), California (CA) \\
\hline HWB14 & Steel, Multi-Column Bent, Simple Support (Seismic Design) \\
\hline HWB15 & Continuous Steel (Conventional Design) \\
\hline HWB16 & Continuous Steel (Seismic Design) \\
\hline HWB17 & PS Concrete Multi-Column Bent, Simple Support - (Conventional Design), Non-California \\
\hline HWB18 & PS Concrete, Multi-Column Bent, Simple Support (Conventional Design), California (CA) \\
\hline HWB19 & PS Concrete, Multi-Column Bent, Simple Support (Seismic Design) \\
\hline HWB20 & PS Concrete, Single Column, Box Girder (Conventional Design) \\
\hline HWB21 & PS Concrete, Single Column, Box Girder (Seismic Design) \\
\hline HWB22 & Continuous Concrete, (Not HWB20/HWB21) (Conventional Design) \\
\hline HWB23 & Continuous Concrete, (Not HWB20/HWB21) (Seismic Design) \\
\hline HWB24 & Same definition as HWB12 except that the bridge length is less than 20 meters \\
\hline HWB25 & Same definition as HWB13 except that the bridge length is less than 20 meters \\
\hline HWB26 & Same definition as HWB15 except that the bridge length is less than 20 meters and Non-CA \\
\hline HWB27 & Same definition as HWB15 except that the bridge length is less than 20 meters and in CA \\
\hline HWB28 & All other bridges that are not classified (including wooden bridges) \\
\hline
\end{tabular}




\subsection{APPENDIX B - DAMAGE ALGORITHMS AND FRAGILITY CURVES FOR BRIDGES}

Table B. 1: Damage Algorithms for Bridges (HAZUS-MH MR4 Technical Manual 2009)

\begin{tabular}{|c|c|c|c|c|c|c|c|c|}
\hline \multirow[b]{2}{*}{ CLASS } & \multicolumn{4}{|c|}{$\begin{array}{c}\text { Sa [1.0 sec in g's] for Damage Functions due to } \\
\text { Ground Shaking }\end{array}$} & \multicolumn{4}{|c|}{$\begin{array}{l}\text { PGD [inches] for Damage Functions due to Ground } \\
\text { Failure }\end{array}$} \\
\hline & Slight & Moderate & Extensive & Complete & Slight & Moderate & Extensive & Complete \\
\hline HWB1 & 0.4 & 0.5 & 0.7 & 0.9 & 3.9 & 3.9 & 3.9 & 13.8 \\
\hline HWB2 & 0.6 & 0.9 & 1.1 & 1.7 & 3.9 & 3.9 & 3.9 & 13.8 \\
\hline HWB3 & 0.8 & 1 & 1.2 & 1.7 & 3.9 & 3.9 & 3.9 & 13.8 \\
\hline HWB4 & 0.8 & 1 & 1.2 & 1.7 & 3.9 & 3.9 & 3.9 & 13.8 \\
\hline HWB5 & 0.25 & 0.35 & 0.45 & 0.7 & 3.9 & 3.9 & 3.9 & 13.8 \\
\hline HWB6 & 0.3 & 0.5 & 0.6 & 0.9 & 3.9 & 3.9 & 3.9 & 13.8 \\
\hline HWB7 & 0.5 & 0.8 & 1.1 & 1.7 & 3.9 & 3.9 & 3.9 & 13.8 \\
\hline HWB8 & 0.35 & 0.45 & 0.55 & 0.8 & 3.9 & 3.9 & 3.9 & 13.8 \\
\hline HWB9 & 0.6 & 0.9 & 1.3 & 1.6 & 3.9 & 3.9 & 3.9 & 13.8 \\
\hline HWB10 & 0.6 & 0.9 & 1.1 & 1.5 & 3.9 & 3.9 & 3.9 & 13.8 \\
\hline HWB11 & 0.9 & 0.9 & 1.1 & 1.5 & 3.9 & 3.9 & 3.9 & 13.8 \\
\hline HWB12 & 0.25 & 0.35 & 0.45 & 0.7 & 3.9 & 3.9 & 3.9 & 13.8 \\
\hline HWB13 & 0.3 & 0.5 & 0.6 & 0.9 & 3.9 & 3.9 & 3.9 & 13.8 \\
\hline HWB14 & 0.5 & 0.8 & 1.1 & 1.7 & 3.9 & 3.9 & 3.9 & 13.8 \\
\hline HWB15 & 0.75 & 0.75 & 0.75 & 1.1 & 3.9 & 3.9 & 3.9 & 13.8 \\
\hline HWB16 & 0.9 & 0.9 & 1.1 & 1.5 & 3.9 & 3.9 & 3.9 & 13.8 \\
\hline HWB17 & 0.25 & 0.35 & 0.45 & 0.7 & 3.9 & 3.9 & 3.9 & 13.8 \\
\hline HWB18 & 0.3 & 0.5 & 0.6 & 0.9 & 3.9 & 3.9 & 3.9 & 13.8 \\
\hline HWB19 & 0.5 & 0.8 & 1.1 & 1.7 & 3.9 & 3.9 & 3.9 & 13.8 \\
\hline HWB20 & 0.35 & 0.45 & 0.55 & 0.8 & 3.9 & 3.9 & 3.9 & 13.8 \\
\hline HWB21 & 0.6 & 0.9 & 1.3 & 1.6 & 3.9 & 3.9 & 3.9 & 13.8 \\
\hline HWB22 & 0.6 & 0.9 & 1.1 & 1.5 & 3.9 & 3.9 & 3.9 & 13.8 \\
\hline HWB23 & 0.9 & 0.9 & 1.1 & 1.5 & 3.9 & 3.9 & 3.9 & 13.8 \\
\hline HWB24 & 0.25 & 0.35 & 0.45 & 0.7 & 3.9 & 3.9 & 3.9 & 13.8 \\
\hline HWB25 & 0.3 & 0.5 & 0.6 & 0.9 & 3.9 & 3.9 & 3.9 & 13.8 \\
\hline HWB26 & 0.75 & 0.75 & 0.75 & 1.1 & 3.9 & 3.9 & 3.9 & 13.8 \\
\hline HWB27 & 0.75 & 0.75 & 0.75 & 1.1 & 3.9 & 3.9 & 3.9 & 13.8 \\
\hline HWB28 & 0.8 & 1 & 1.2 & 1.7 & 3.9 & 3.9 & 3.9 & 13.8 \\
\hline
\end{tabular}


Table B. 2: Median Ground Motions Leading to Onset of Various Damage States for Conventionally Designed "Standard” Bridges. (REDARS2 Technical Manual, 2006)

\begin{tabular}{|c|c|c|c|c|}
\hline \multirow[t]{2}{*}{ Bridge Type } & \multirow[t]{2}{*}{ NBI Class } & \multirow[t]{2}{*}{$\begin{array}{l}\text { Damage } \\
\text { State }\end{array}$} & \multicolumn{2}{|c|}{$\begin{array}{l}\text { Median Spectral Acceleration, } \mathrm{g} \text {, at } \\
\text { Period = 1.0 sec. for Damage } \\
\text { Functions due to Ground Shaking }\end{array}$} \\
\hline & & & Non- California & California \\
\hline Single Span & All & $\begin{array}{l}2 \\
3 \\
4 \\
5\end{array}$ & $\begin{array}{l}\mathbf{0 . 8 0}{ }^{* 1} \\
1.00 \\
1.20 \\
1.70\end{array}$ & $\begin{array}{l}0.80 * \\
1.00 \\
1.20 \\
1.70\end{array}$ \\
\hline Major Bridges & All & $\begin{array}{l}2 \\
3 \\
4 \\
5\end{array}$ & $\begin{array}{l}0.40 \\
0.50 \\
0.70 \\
0.90\end{array}$ & $\begin{array}{l}0.40 \\
0.50 \\
0.60 \\
0.90\end{array}$ \\
\hline $\begin{array}{l}\text { Multi-Column Bents and Simply- } \\
\text { Supported Concrete Superstructure }\end{array}$ & $\begin{array}{l}101-106 \\
501-506\end{array}$ & $\begin{array}{l}2 \\
3 \\
4 \\
5\end{array}$ & $\begin{array}{l}0.25 \\
0.35 \\
0.45 \\
0.70\end{array}$ & $\begin{array}{l}0.30 \\
0.50 \\
0.60 \\
0.90\end{array}$ \\
\hline $\begin{array}{l}\text { Single-Column Bents and Concrete Box- } \\
\text { Girder Superstructure }\end{array}$ & $\begin{array}{l}205-206 \\
605-606\end{array}$ & $\begin{array}{l}2 \\
3 \\
4 \\
5\end{array}$ & Not Applicable & $\begin{array}{l}0.35 \\
0.45 \\
0.55 \\
0.80\end{array}$ \\
\hline $\begin{array}{c}\text { Continuous Reinforced-Concrete } \\
\text { Superstructure }\end{array}$ & 201-204 & $\begin{array}{l}2 \\
3 \\
4 \\
5\end{array}$ & $\begin{array}{l}0.60 * \\
0.90 \\
1.10 \\
1.50\end{array}$ & $\begin{array}{l}0.90^{*} \\
0.90 \\
1.10 \\
1.50\end{array}$ \\
\hline $\begin{array}{c}\text { Continuous Prestressed-Concrete } \\
\text { Superstructure }\end{array}$ & $\begin{array}{c}601-604 \\
607\end{array}$ & $\begin{array}{l}2 \\
3 \\
4 \\
5\end{array}$ & $\begin{array}{l}0.60 * \\
0.90 \\
1.10 \\
1.50\end{array}$ & $\begin{array}{l}0.90^{*} \\
0.90 \\
1.10 \\
1.50\end{array}$ \\
\hline Simply-Supported Steel Superstructure & 301-310 & $\begin{array}{l}2 \\
3 \\
4 \\
5\end{array}$ & $\begin{array}{l}0.25 \\
0.35 \\
0.45 \\
0.70\end{array}$ & $\begin{array}{l}0.30 \\
0.50 \\
0.60 \\
0.90\end{array}$ \\
\hline Continuous Steel Superstructure & $402-410$ & $\begin{array}{l}2 \\
3 \\
4 \\
5\end{array}$ & $\begin{array}{l}0.75^{*} \\
0.75 \\
0.75 \\
1.10\end{array}$ & $\begin{array}{l}0.75 * \\
0.75 \\
0.75 \\
1.10\end{array}$ \\
\hline Continuous Steel Superstructure & All & $\begin{array}{l}2 \\
3 \\
4 \\
5\end{array}$ & $\begin{array}{l}0.80 \\
1.00 \\
1.20 \\
1.70\end{array}$ & $\begin{array}{l}0.80 \\
1.00 \\
1.20 \\
1.70\end{array}$ \\
\hline
\end{tabular}

\footnotetext{
$1 *$ Short period motions govern; therefore use demand and capacity at $0.3 \mathrm{sec}$. to assess damage state.
} 
Table B. 3: Median Ground Motions Leading to Onset of Various Damage States for Seismically Designed "Standard" Bridges. (REDARS2 Technical Manual, 2006)

\begin{tabular}{|c|c|c|c|c|}
\hline \multirow[t]{2}{*}{ Bridge Type } & \multirow[t]{2}{*}{ NBI Class } & \multirow[t]{2}{*}{$\begin{array}{l}\text { Damage } \\
\text { State }\end{array}$} & \multicolumn{2}{|c|}{$\begin{array}{c}\text { Median Spectral Acceleration, } \\
\text { g, at } \\
\text { Period }=1.0 \text { sec. for Damage }\end{array}$} \\
\hline & & & Non- California & California \\
\hline Single Span & All & $\begin{array}{l}2 \\
3 \\
4 \\
5\end{array}$ & $\begin{array}{c}0.80 *{ }^{2} \\
1.00 \\
1.20 \\
1.70\end{array}$ & $\begin{array}{c}0.80 * \\
1.00 \\
1.20 \\
1.70\end{array}$ \\
\hline Major Bridges & All & $\begin{array}{l}2 \\
3 \\
4 \\
5\end{array}$ & $\begin{array}{l}0.60 \\
0.90 \\
1.10 \\
1.70\end{array}$ & $\begin{array}{l}0.60 \\
0.90 \\
1.10 \\
1.70\end{array}$ \\
\hline $\begin{array}{l}\text { Multi-Column Bents and Simply- } \\
\text { Supported Concrete Superstructure }\end{array}$ & $\begin{array}{r}101-106 \\
501-506\end{array}$ & $\begin{array}{l}2 \\
3 \\
4 \\
5\end{array}$ & $\begin{array}{l}0.50 \\
0.80 \\
1.10 \\
1.07\end{array}$ & $\begin{array}{l}0.50 \\
0.80 \\
1.10 \\
1.70\end{array}$ \\
\hline $\begin{array}{l}\text { Single-Column Bents and Concrete Box- } \\
\text { Girder Superstructure }\end{array}$ & $\begin{array}{r}205-206 \\
605-606\end{array}$ & $\begin{array}{l}2 \\
3 \\
4 \\
5\end{array}$ & Not Applicable & $\begin{array}{l}0.60 \\
0.90 \\
1.30 \\
1.60\end{array}$ \\
\hline $\begin{array}{c}\text { Continuous Reinforced-Concrete } \\
\text { Superstructure }\end{array}$ & 201-204 & $\begin{array}{l}2 \\
3 \\
4 \\
5\end{array}$ & $\begin{array}{l}0.90 * \\
0.90 \\
1.10 \\
1.50\end{array}$ & $\begin{array}{l}0.90 * \\
0.90 \\
1.10 \\
1.50\end{array}$ \\
\hline $\begin{array}{c}\text { Continuous Prestressed-Concrete } \\
\text { Superstructure }\end{array}$ & $\begin{array}{c}601-604 \\
607\end{array}$ & $\begin{array}{l}2 \\
3 \\
4 \\
5\end{array}$ & $\begin{array}{l}0.90 * \\
0.90 \\
1.10 \\
1.50\end{array}$ & $\begin{array}{l}0.90 * \\
0.90 \\
1.10 \\
1.50\end{array}$ \\
\hline Simply-Supported Steel Superstructure & 301-310 & $\begin{array}{l}2 \\
3 \\
4 \\
5\end{array}$ & $\begin{array}{l}0.50 \\
0.80 \\
1.10 \\
1.07\end{array}$ & $\begin{array}{l}0.50 \\
0.80 \\
1.10 \\
1.07\end{array}$ \\
\hline Continuous Steel Superstructure & $402-410$ & $\begin{array}{l}2 \\
3 \\
4 \\
5\end{array}$ & $\begin{array}{l}0.90^{*} \\
0.90 \\
1.10 \\
1.50\end{array}$ & $\begin{array}{l}0.90 * \\
0.90 \\
1.10 \\
1.50\end{array}$ \\
\hline Continuous Steel Superstructure & All & $\begin{array}{l}2 \\
3 \\
4 \\
5\end{array}$ & $\begin{array}{l}0.80 \\
1.00 \\
1.20 \\
1.70\end{array}$ & $\begin{array}{l}0.80 \\
1.00 \\
1.20 \\
1.70\end{array}$ \\
\hline
\end{tabular}

\footnotetext{
$2 *$ Short period motions govern; therefore use demand and capacity at $0.3 \mathrm{sec}$. to assess damage state.
} 
Table B. 4: HAZUS Bridge Classification Scheme

\begin{tabular}{|c|c|c|c|c|c|c|c|c|}
\hline Class & $\begin{array}{l}\text { NBI } \\
\text { Class }\end{array}$ & State & $\begin{array}{l}\text { Year } \\
\text { built }\end{array}$ & $\begin{array}{l}\text { \# of } \\
\text { Span }\end{array}$ & $\begin{array}{c}\text { Length } \\
\text { of max } \\
\text { Span } \\
\text { (meters) }\end{array}$ & $\begin{array}{c}\text { Length } \\
\text { less } \\
\text { than } \\
20 \mathrm{~m}\end{array}$ & Design & Description \\
\hline HWB1 & All & $\begin{array}{l}\text { Non- } \\
\text { CA }\end{array}$ & $<1990$ & & $>150$ & N/A & Conventional & $\begin{array}{c}\text { Major Bridge - Length }> \\
150 \mathrm{~m}\end{array}$ \\
\hline HWB1 & All & $\mathbf{C A}$ & $<1975$ & & $>150$ & N/A & Conventional & $\begin{array}{c}\text { Major Bridge - Length }> \\
150 \mathrm{~m}\end{array}$ \\
\hline HWB2 & All & $\begin{array}{c}\text { Non- } \\
\text { CA }\end{array}$ & $\geq 1990$ & & $>150$ & N/A & Seismic & $\begin{array}{c}\text { Major Bridge - Length > } \\
150 \mathrm{~m}\end{array}$ \\
\hline HWB2 & All & CA & $\geq 1975$ & & $>150$ & N/A & Seismic & $\begin{array}{c}\text { Major Bridge - Length }> \\
150 \mathrm{~m}\end{array}$ \\
\hline HWB3 & All & $\begin{array}{l}\text { Non- } \\
\text { CA }\end{array}$ & $<1990$ & 1 & & N/A & Conventional & Single Span \\
\hline HWB3 & All & $\mathbf{C A}$ & $<1975$ & 1 & & N/A & Conventional & Single Span \\
\hline HWB4 & All & $\begin{array}{l}\text { Non- } \\
\text { CA }\end{array}$ & $\geq 1990$ & 1 & & N/A & Seismic & Single Span \\
\hline HWB4 & All & CA & $\geq 1975$ & 1 & & N/A & Seismic & Single Span \\
\hline HWB5 & $\begin{array}{l}101- \\
106\end{array}$ & $\begin{array}{l}\text { Non- } \\
\text { CA }\end{array}$ & $<1990$ & & & N/A & Conventional & $\begin{array}{l}\text { Multi-Col. Bent Simple } \\
\text { Support -concrete }\end{array}$ \\
\hline HWB6 & $\begin{array}{l}101- \\
106\end{array}$ & $\mathbf{C A}$ & $<1975$ & & & N/A & Conventional & $\begin{array}{l}\text { Multi-Col. Bent Simple } \\
\text { Support -concrete }\end{array}$ \\
\hline HWB7 & $\begin{array}{l}101- \\
106\end{array}$ & $\begin{array}{l}\text { Non- } \\
\text { CA }\end{array}$ & $\geq 1990$ & & & N/A & Seismic & $\begin{array}{l}\text { Multi-Col. Bent Simple } \\
\text { Support -concrete }\end{array}$ \\
\hline HWB7 & $\begin{array}{l}101- \\
106\end{array}$ & CA & $\geq 1975$ & & & N/A & Seismic & $\begin{array}{l}\text { Multi-Col. Bent Simple } \\
\text { Support -concrete }\end{array}$ \\
\hline HWB8 & $\begin{array}{l}205- \\
206\end{array}$ & $\mathbf{C A}$ & $<1975$ & & & N/A & Conventional & $\begin{array}{c}\text { Single Col. Box Girder - C } \\
\text { Concrete }\end{array}$ \\
\hline HWB9 & $\begin{array}{l}205- \\
206\end{array}$ & CA & $\geq 1975$ & & & N/A & Seismic & $\begin{array}{c}\text { Single Col. Box Girder - C } \\
\text { Concrete }\end{array}$ \\
\hline HWB10 & $\begin{array}{l}201- \\
206\end{array}$ & $\begin{array}{l}\text { Non- } \\
\text { CA }\end{array}$ & $<1990$ & & & N/A & Conventional & Continuous Concrete \\
\hline
\end{tabular}


Table B. 5: HAZUS Bridge Classification Scheme (Continued)

\begin{tabular}{|c|c|c|c|c|c|c|c|c|}
\hline Class & $\begin{array}{l}\text { NBI } \\
\text { Class }\end{array}$ & State & $\begin{array}{l}\text { Year } \\
\text { built }\end{array}$ & $\begin{array}{c}\text { \# of } \\
\text { Span }\end{array}$ & $\begin{array}{c}\text { Length } \\
\text { of max } \\
\text { Span } \\
\text { (meters) }\end{array}$ & $\begin{array}{l}\text { Length } \\
\text { less than } \\
20 \mathrm{~m}\end{array}$ & Design & Description \\
\hline HWB10 & 201-206 & CA & $\begin{array}{c}< \\
1975\end{array}$ & & & N/A & Conventional & Continuous Concrete \\
\hline HWB11 & 201-206 & Non-CA & $\geq 1990$ & & & $\mathbf{N} / \mathbf{A}$ & Seismic & Continuous Concrete \\
\hline HWB11 & 201-206 & $\mathbf{C A}$ & $\geq 1975$ & & & N/A & Seismic & Continuous Concrete \\
\hline HWB12 & 301-306 & Non-CA & $\begin{array}{c}< \\
1990\end{array}$ & & & No & Conventional & $\begin{array}{l}\text { Multi-Col. Bent Simple } \\
\text { Support -Steel }\end{array}$ \\
\hline HWB13 & 301-306 & $\mathbf{C A}$ & $\begin{array}{c}< \\
1975\end{array}$ & & & No & Conventional & $\begin{array}{l}\text { Multi-Col. Bent Simple } \\
\text { Support -Steel }\end{array}$ \\
\hline HWB14 & 301-306 & Non-CA & $\geq 1990$ & & & N/A & Seismic & $\begin{array}{l}\text { Multi-Col. Bent Simple } \\
\text { Support -Steel }\end{array}$ \\
\hline HWB14 & 301-306 & CA & $\geq 1975$ & & & N/A & Seismic & $\begin{array}{l}\text { Multi-Col. Bent Simple } \\
\text { Support -Steel }\end{array}$ \\
\hline HWB15 & $402-410$ & Non-CA & $\begin{array}{c}< \\
1990\end{array}$ & & & No & Conventional & Continuous Steel \\
\hline HWB15 & $402-410$ & CA & $\begin{array}{c}< \\
1975\end{array}$ & & & No & Conventional & Continuous Steel \\
\hline HWB16 & $402-410$ & Non-CA & $\geq 1990$ & & & N/A & Seismic & Continuous Steel \\
\hline HWB16 & $402-410$ & $\mathbf{C A}$ & $\geq 1975$ & & & N/A & Seismic & Continuous Steel \\
\hline HWB17 & 501-506 & Non-CA & $\begin{array}{c}< \\
1990\end{array}$ & & & N/A & Conventional & $\begin{array}{c}\text { Multi-Col. Bent, Simple } \\
\text { Support - Prestressed } \\
\text { Concrete }\end{array}$ \\
\hline HWB18 & 501-506 & $\mathbf{C A}$ & $\begin{array}{c}< \\
1975\end{array}$ & & & N/A & Conventional & $\begin{array}{c}\text { Multi-Col. Bent, Simple } \\
\text { Support - Prestressed } \\
\text { Concrete }\end{array}$ \\
\hline HWB19 & 501-506 & Non-CA & $\geq 1990$ & & & N/A & Seismic & $\begin{array}{c}\text { Multi-Col. Bent, Simple } \\
\text { Support - Prestressed } \\
\text { Concrete }\end{array}$ \\
\hline HWB19 & $501-506$ & CA & $\geq 1975$ & & & N/A & Seismic & $\begin{array}{c}\text { Multi-Col. Bent, Simple } \\
\text { Support - Prestressed } \\
\text { Concrete }\end{array}$ \\
\hline
\end{tabular}


Table B. 6: HAZUS Bridge Classification Scheme (Continued)

\begin{tabular}{|c|c|c|c|c|c|c|c|c|}
\hline Class & $\begin{array}{l}\text { NBI } \\
\text { Class }\end{array}$ & State & $\begin{array}{l}\text { Year } \\
\text { built }\end{array}$ & $\begin{array}{l}\text { \# of } \\
\text { Span }\end{array}$ & $\begin{array}{c}\text { Length } \\
\text { of max } \\
\text { Span } \\
\text { (meters) }\end{array}$ & $\begin{array}{c}\text { Length } \\
\text { less } \\
\text { than } \\
20 \mathrm{~m}\end{array}$ & Design & Description \\
\hline HWB20 & $\begin{array}{c}605- \\
606\end{array}$ & CA & $<1975$ & & & N/A & Conventional & $\begin{array}{c}\text { Single-Col. Bent, Simple } \\
\text { Support - Prestressed } \\
\text { Concrete }\end{array}$ \\
\hline HWB21 & $\begin{array}{c}605- \\
606\end{array}$ & CA & $\geq 1975$ & & & N/A & Seismic & $\begin{array}{l}\text { Single-Col. Bent, Simple } \\
\text { Support - Prestressed } \\
\text { Concrete }\end{array}$ \\
\hline HWB22 & $\begin{array}{l}601- \\
607\end{array}$ & $\begin{array}{c}\text { Non- } \\
\text { CA }\end{array}$ & $<1990$ & & & N/A & Conventional & Continuous Concrete \\
\hline HWB22 & $\begin{array}{l}601- \\
607\end{array}$ & CA & $<1975$ & & & N/A & Conventional & Continuous Concrete \\
\hline HWB23 & $\begin{array}{l}601- \\
607\end{array}$ & $\begin{array}{c}\text { Non- } \\
\text { CA }\end{array}$ & $\geq 1990$ & & & N/A & Seismic & Continuous Concrete \\
\hline HWB23 & $\begin{array}{l}\text { 601- } \\
607\end{array}$ & CA & $\geq 1975$ & & & N/A & Seismic & Continuous Concrete \\
\hline HWB24 & $\begin{array}{l}301- \\
306\end{array}$ & $\begin{array}{c}\text { Non- } \\
\text { CA }\end{array}$ & $<1990$ & & & Yes & Conventional & $\begin{array}{l}\text { Multi-Col. Bent Simple } \\
\text { support - Steel }\end{array}$ \\
\hline HWB25 & $\begin{array}{l}301- \\
306\end{array}$ & CA & $<1975$ & & & Yes & Conventional & $\begin{array}{l}\text { Multi-Col. Bent Simple } \\
\text { support - Steel }\end{array}$ \\
\hline HWB26 & $\begin{array}{l}402- \\
410\end{array}$ & $\begin{array}{c}\text { Non- } \\
\text { CA }\end{array}$ & $<1990$ & & & Yes & Conventional & Continuous Steel \\
\hline HWB27 & $\begin{array}{l}402- \\
410\end{array}$ & CA & $<1975$ & & & Yes & Conventional & Continuous Steel \\
\hline HWB28 & All & & & & & & & $\begin{array}{c}\text { Other bridges that are not } \\
\text { classified }\end{array}$ \\
\hline
\end{tabular}




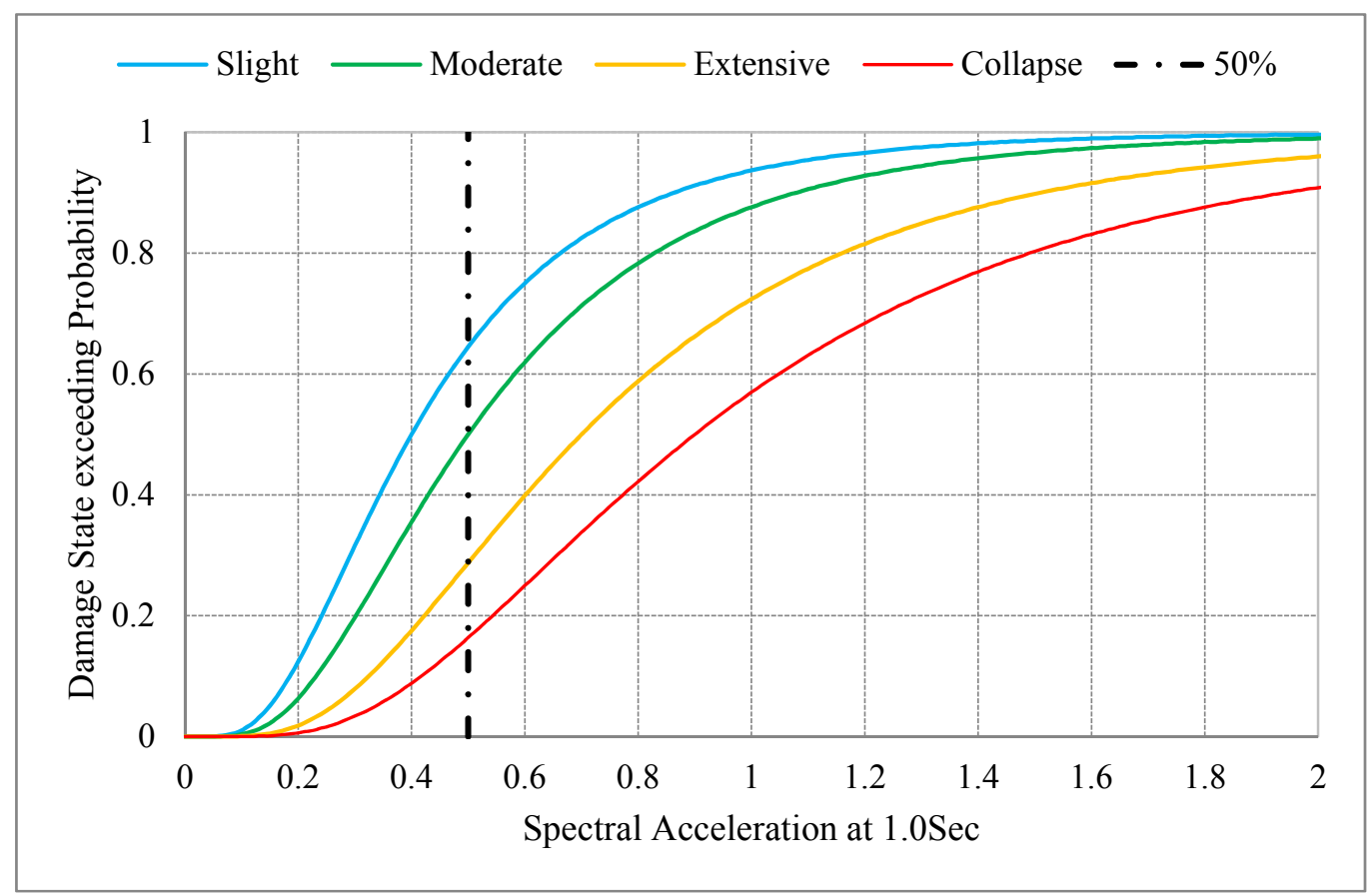

Figure B. 1: Fragility Curves for Conventionally Designed Major Bridges (HWB1).

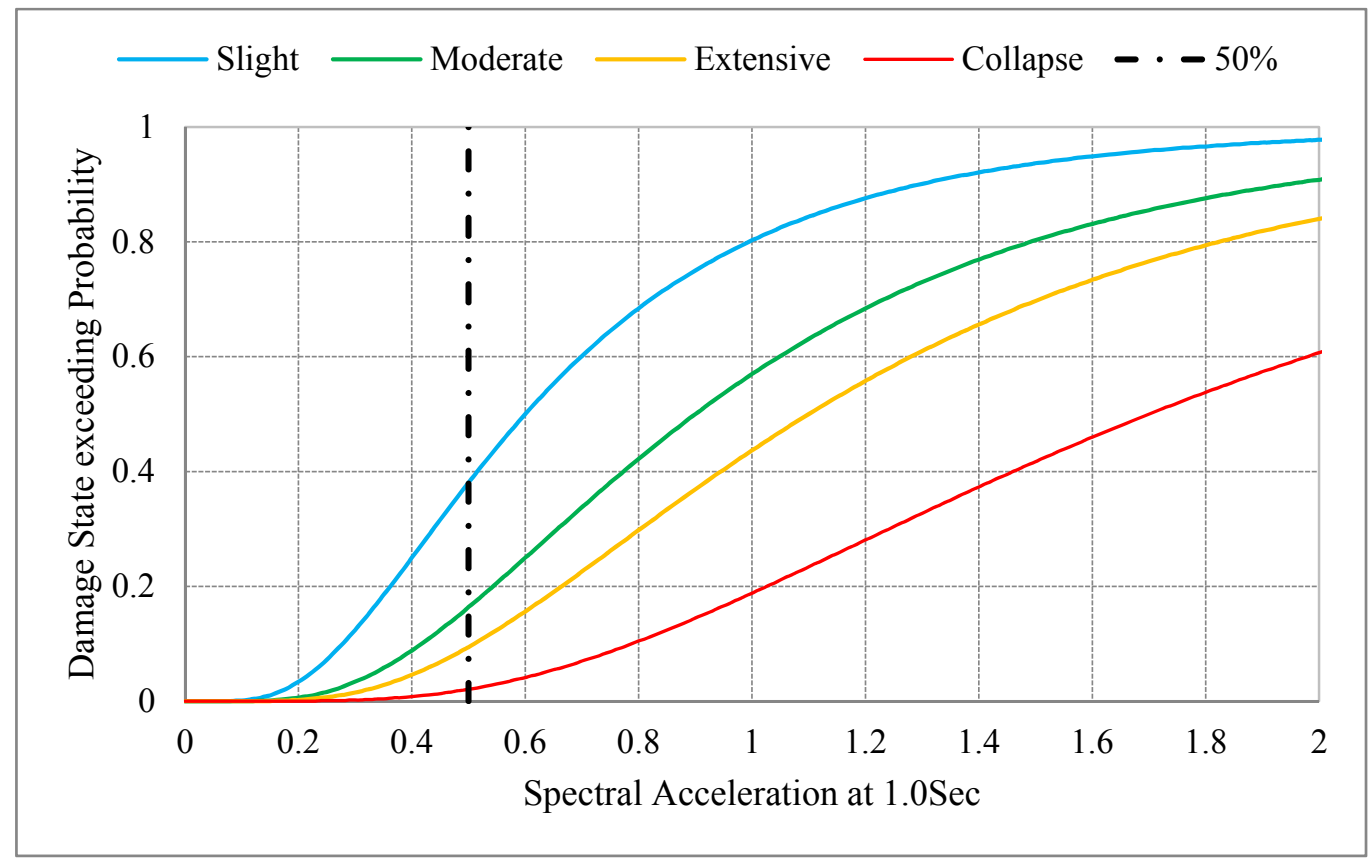

Figure B. 2: Fragility Curves for Conventionally Designed Major Bridges (HWB2). 


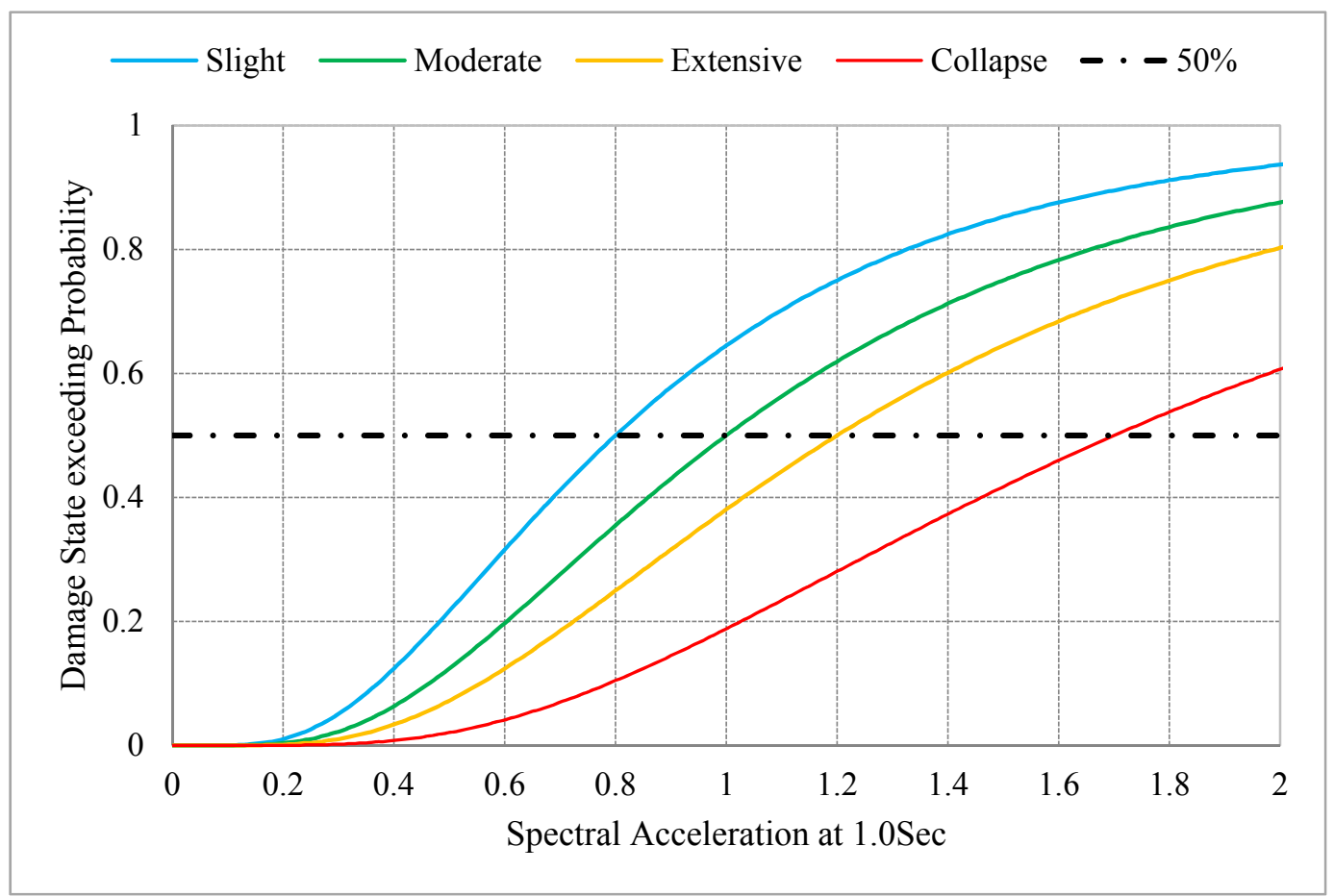

Figure B. 3: Fragility Curves for Conventionally Designed Major Bridges (HWB3, 4 \& 18).

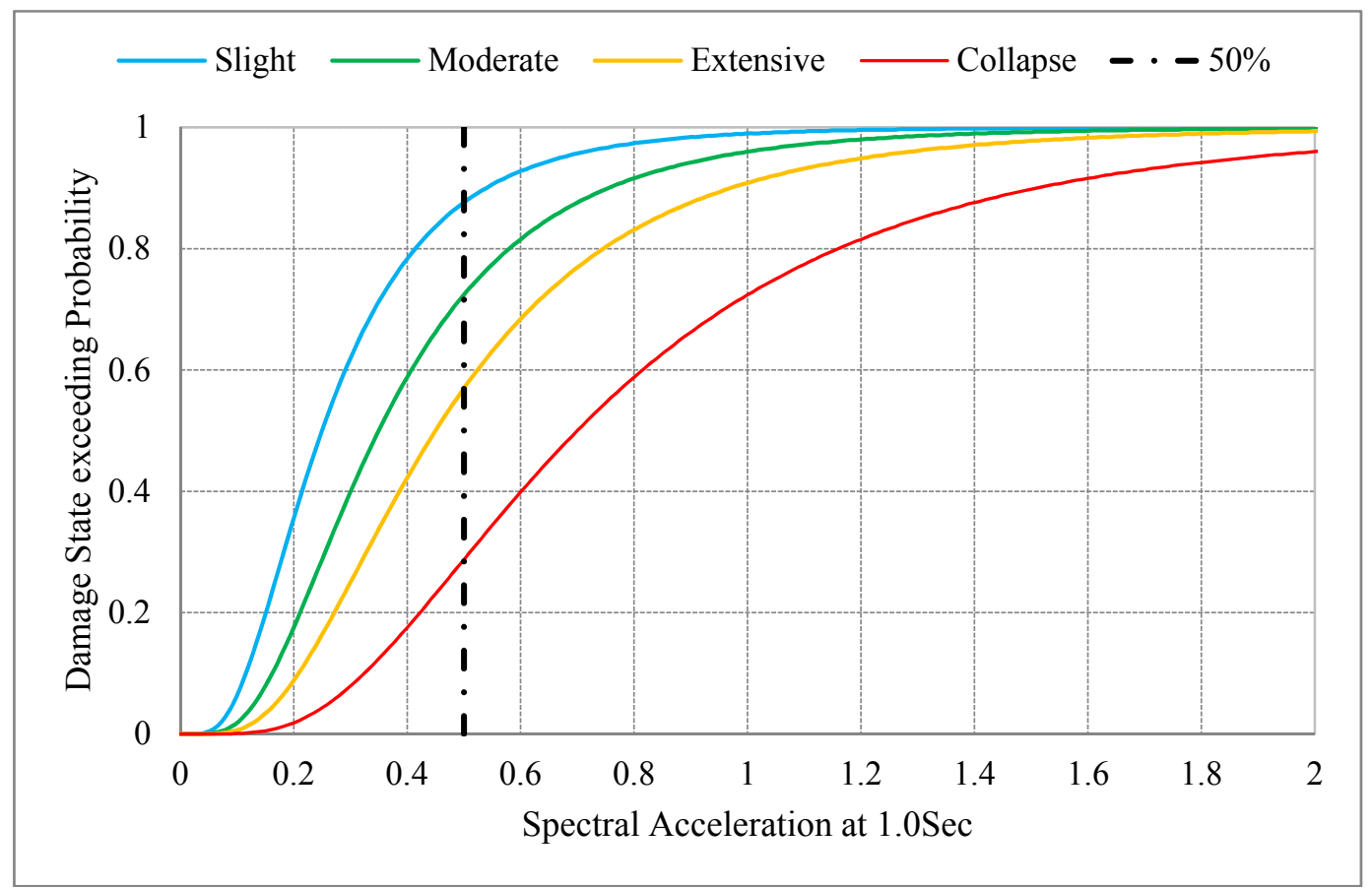

Figure B. 4: Fragility Curves for Conventionally Designed Major Bridges (HWB5, 12, 17 \& 24). 


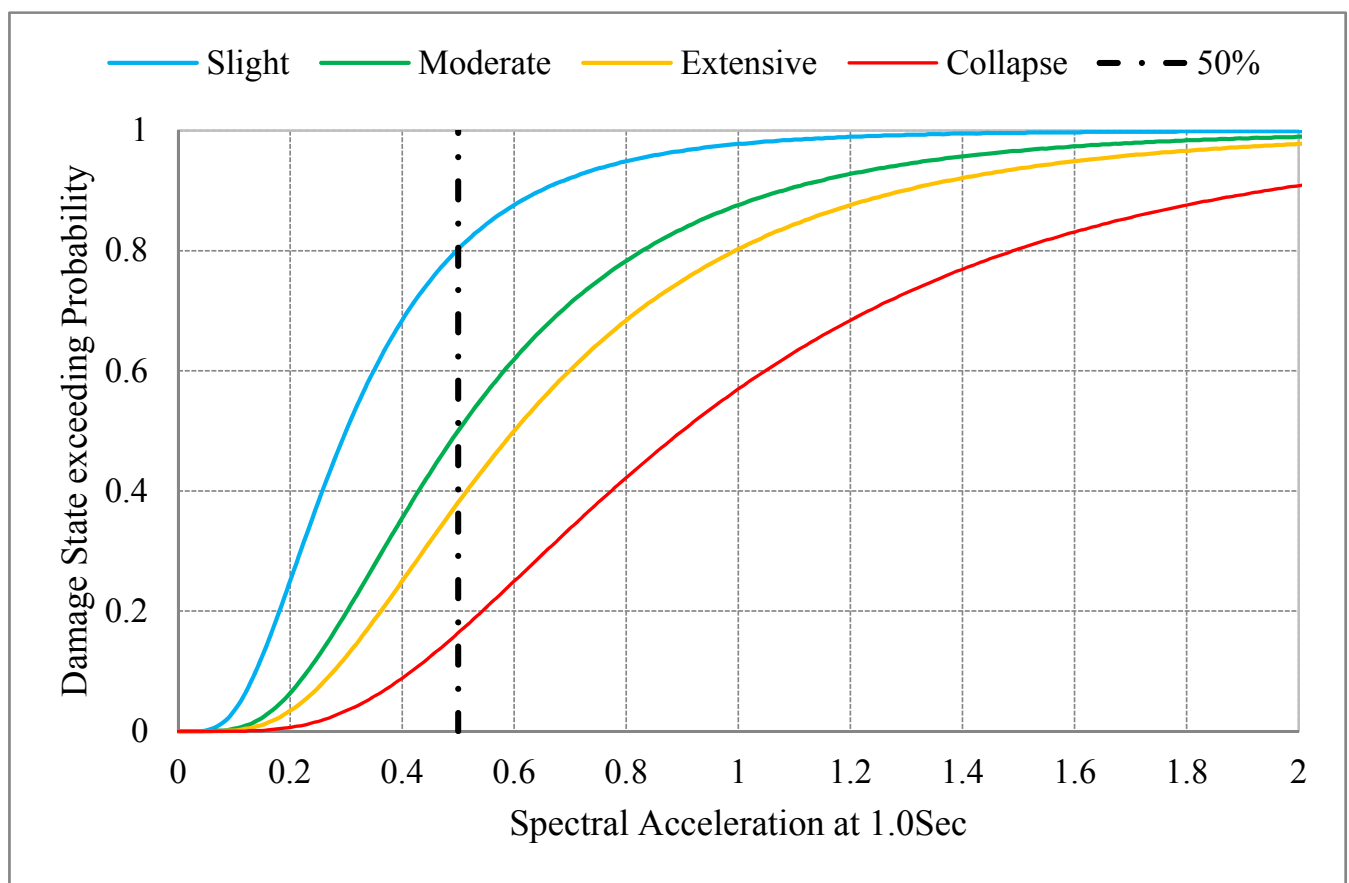

Figure B. 5: Fragility Curves for Conventionally Designed Major Bridges (HWB6, 13, 18 \& 25).

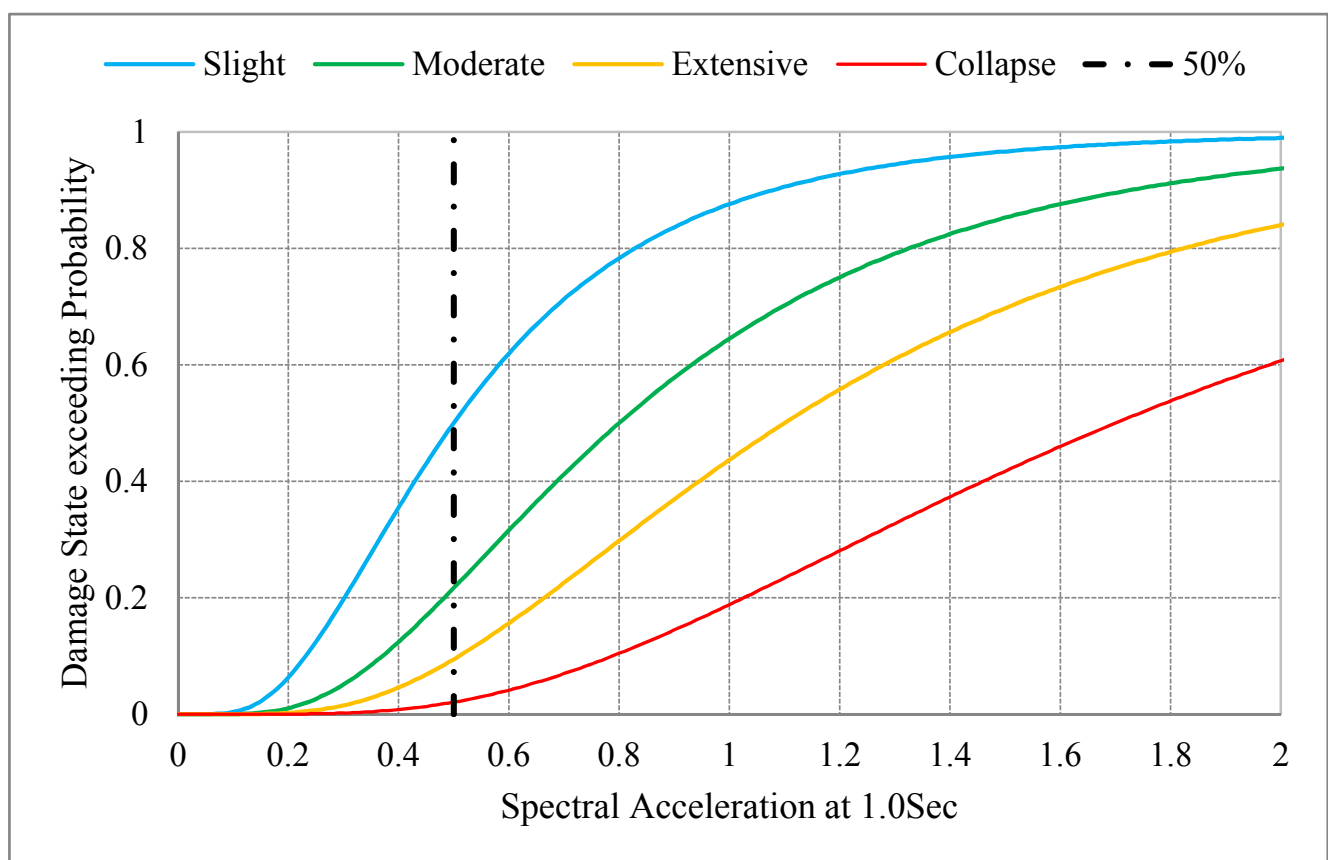

Figure B. 6: Fragility Curves for Conventionally Designed Major Bridges (HWB7, 14 \& 19). 


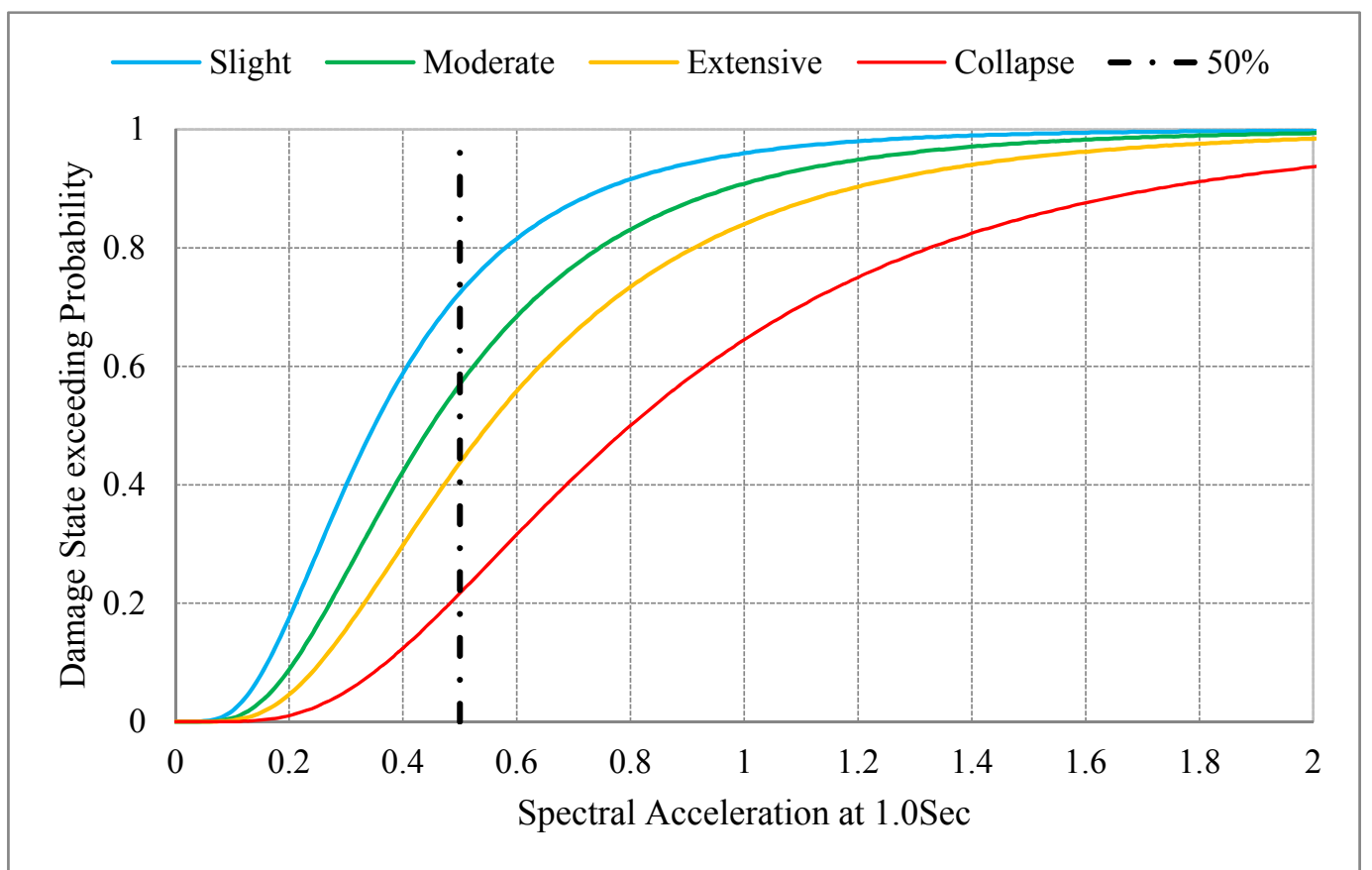

Figure B. 7: Fragility Curves for Conventionally Designed Major Bridges (HWB8 \& HWB20).

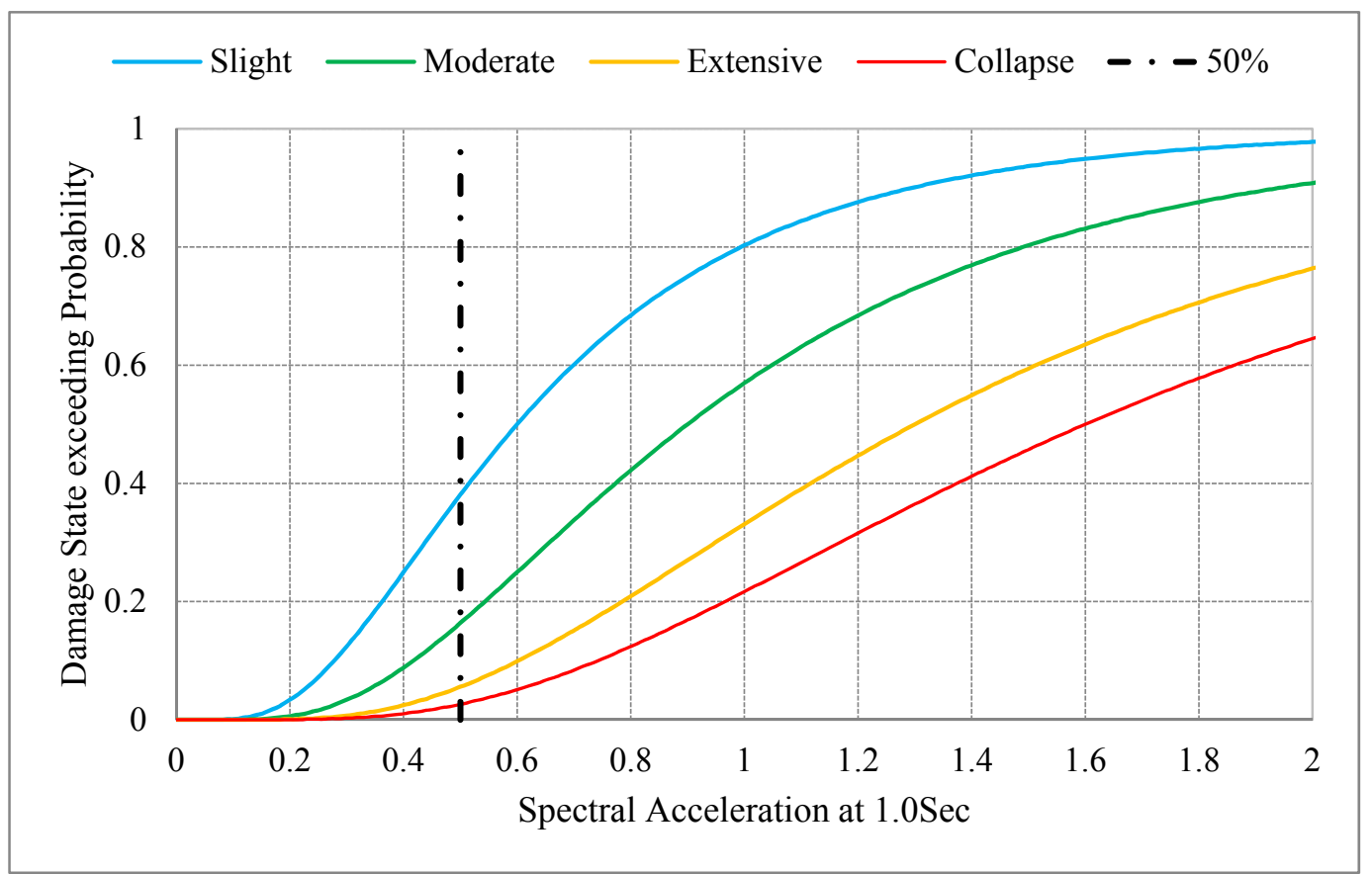

Figure B. 8: Fragility Curves for Conventionally Designed Major Bridges (HWB9 \& HWB21). 


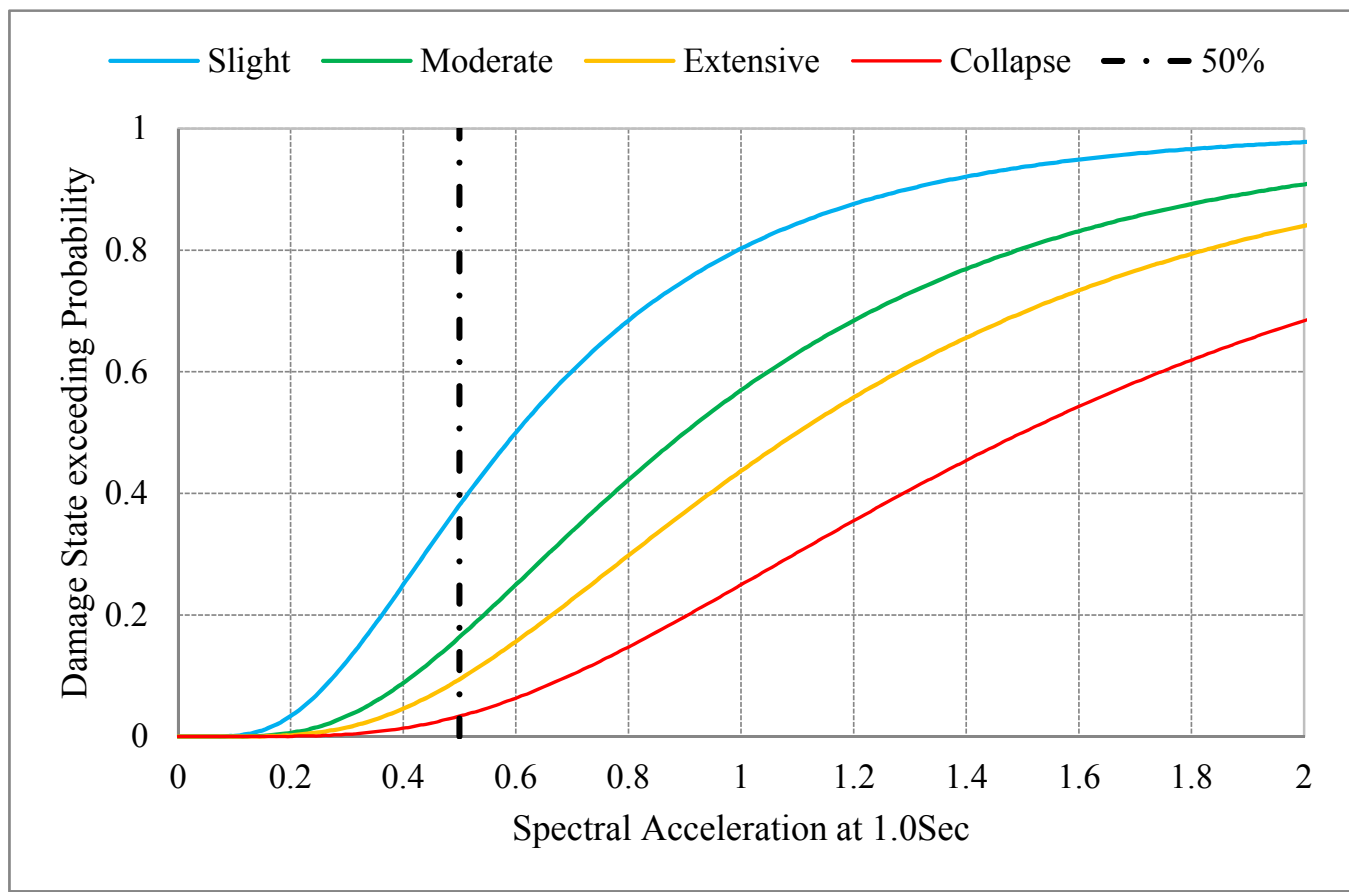

Figure B. 9: Fragility Curves for Conventionally Designed Major Bridges (HWB10, 11, 22 \& 23).

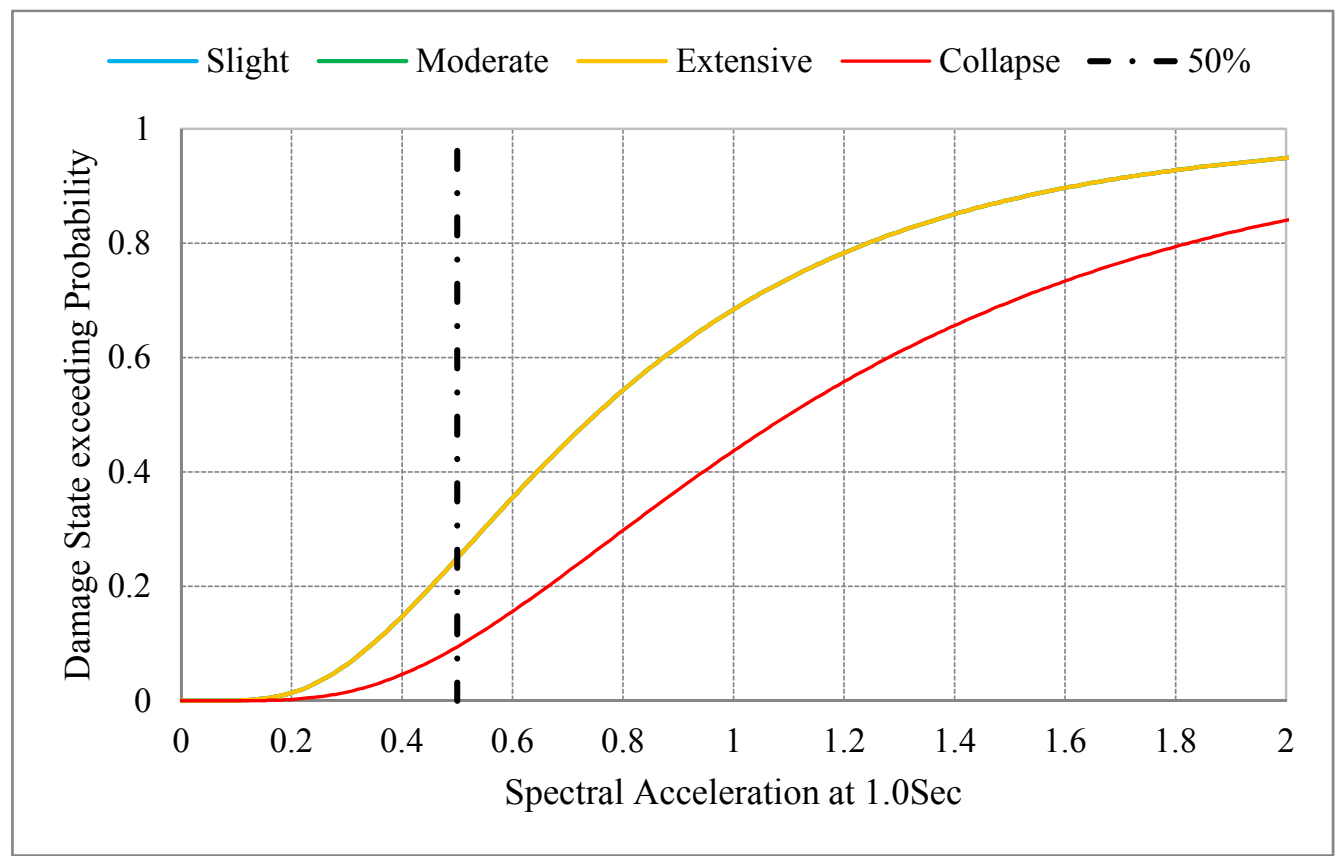

Figure B. 10: Fragility Curves for Conventionally Designed Major Bridges (HWB15, 26 \& 27). 


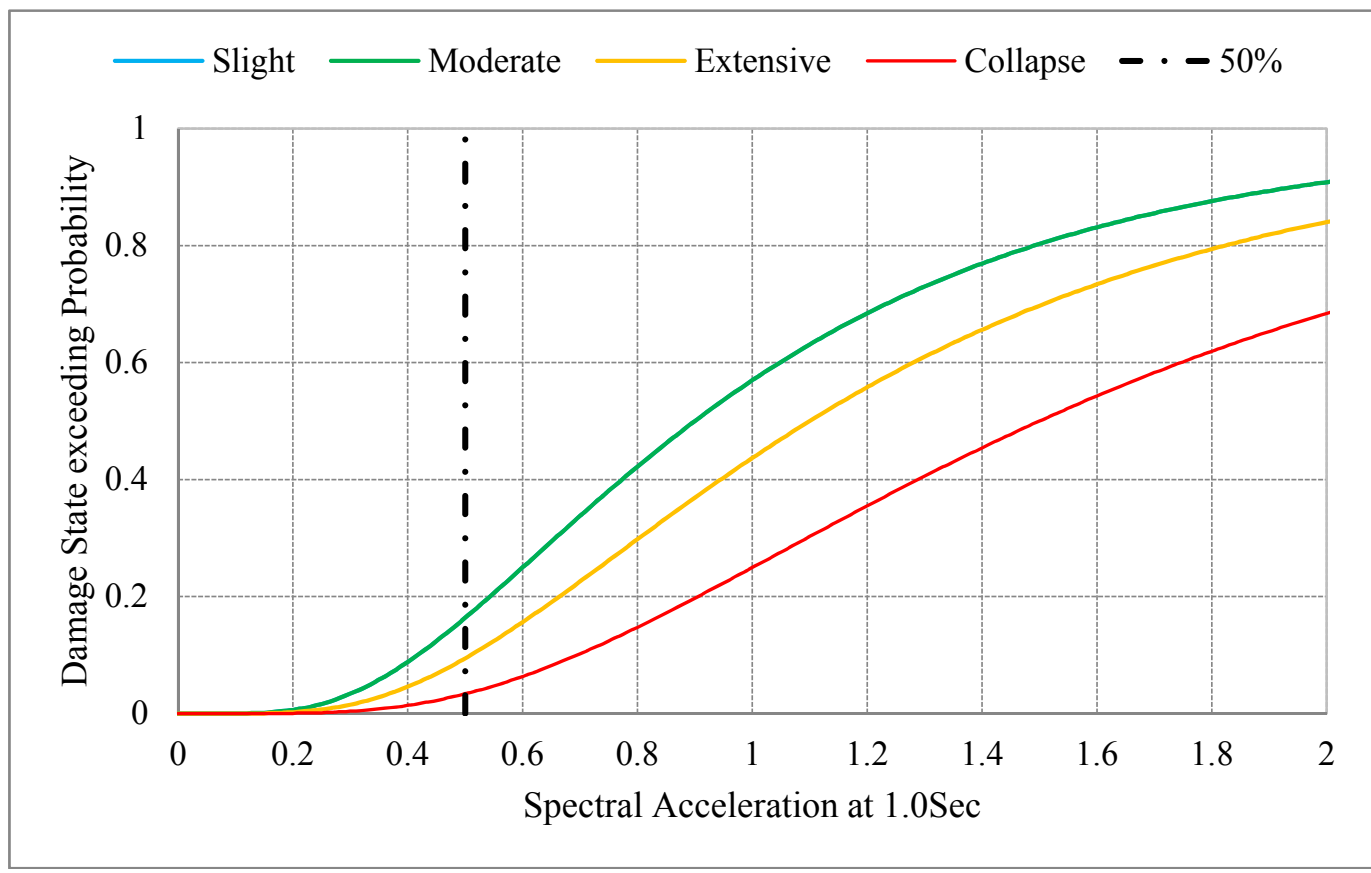

Figure B. 11: Fragility Curves for Conventionally Designed Major Bridges (HWB16). 


\subsection{APPENDIX C - SCENARIO RESULTS BY HIGHWAY ROUTE AND BRIDGE TYPE}

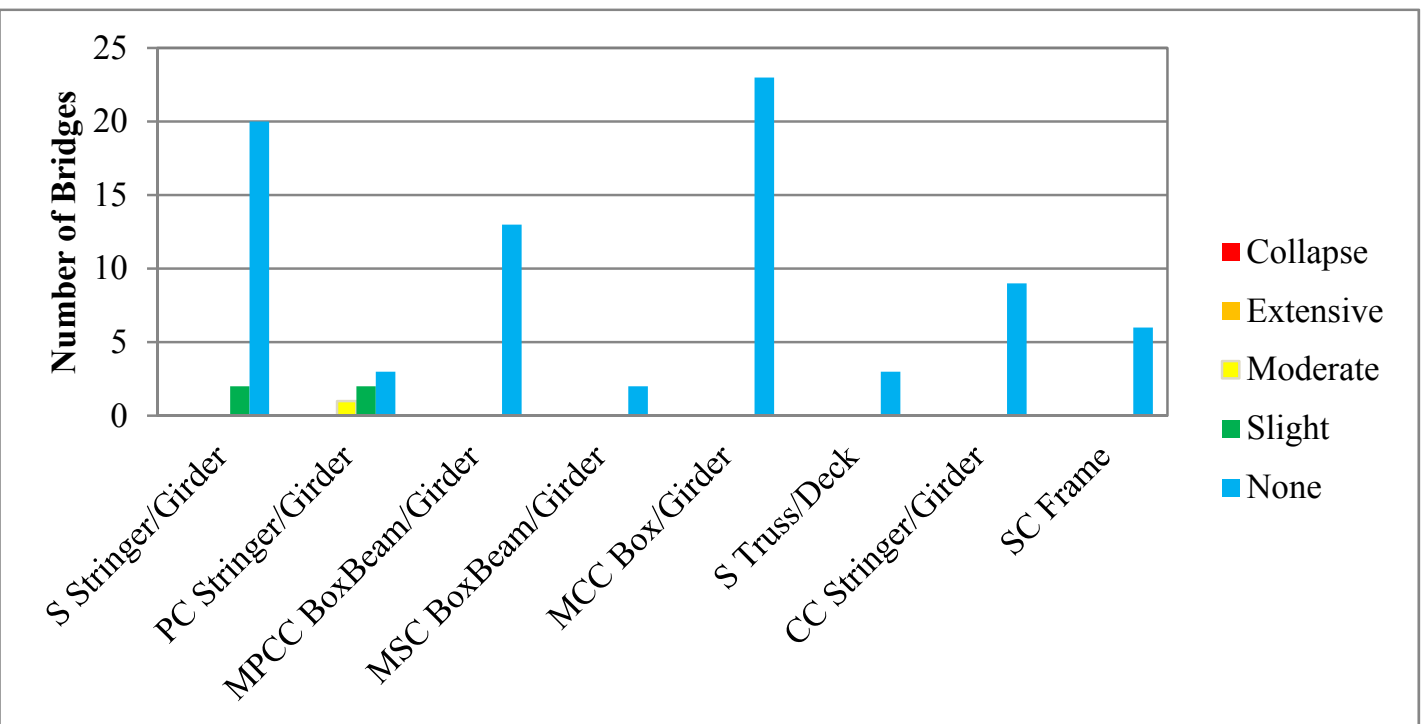

Figure C. 1: Cascadia M9.0 Scenario on I-5 from Multnomah to Clackamas County.

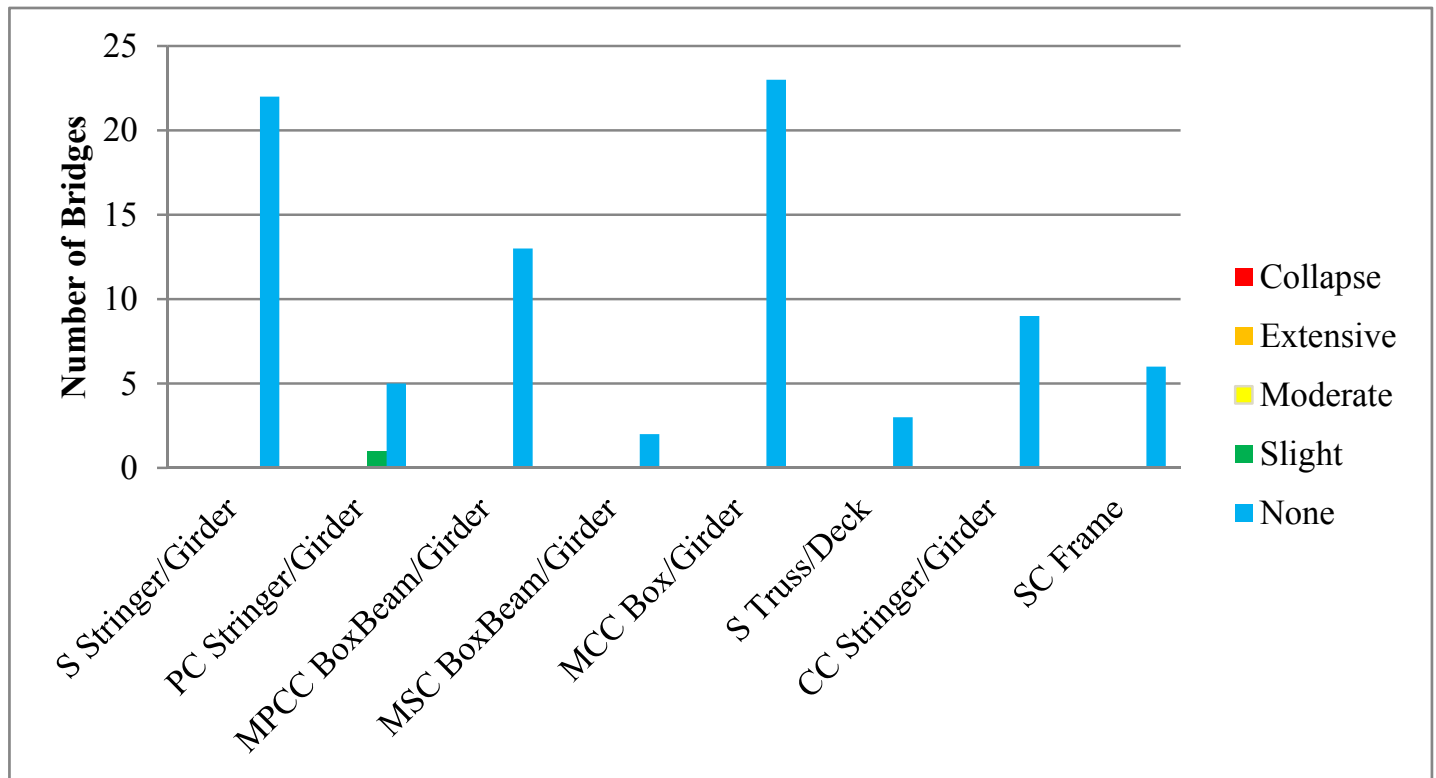

Figure C. 2: North M8.3 Scenario on I-5 from Multnomah to Clackamas County. 


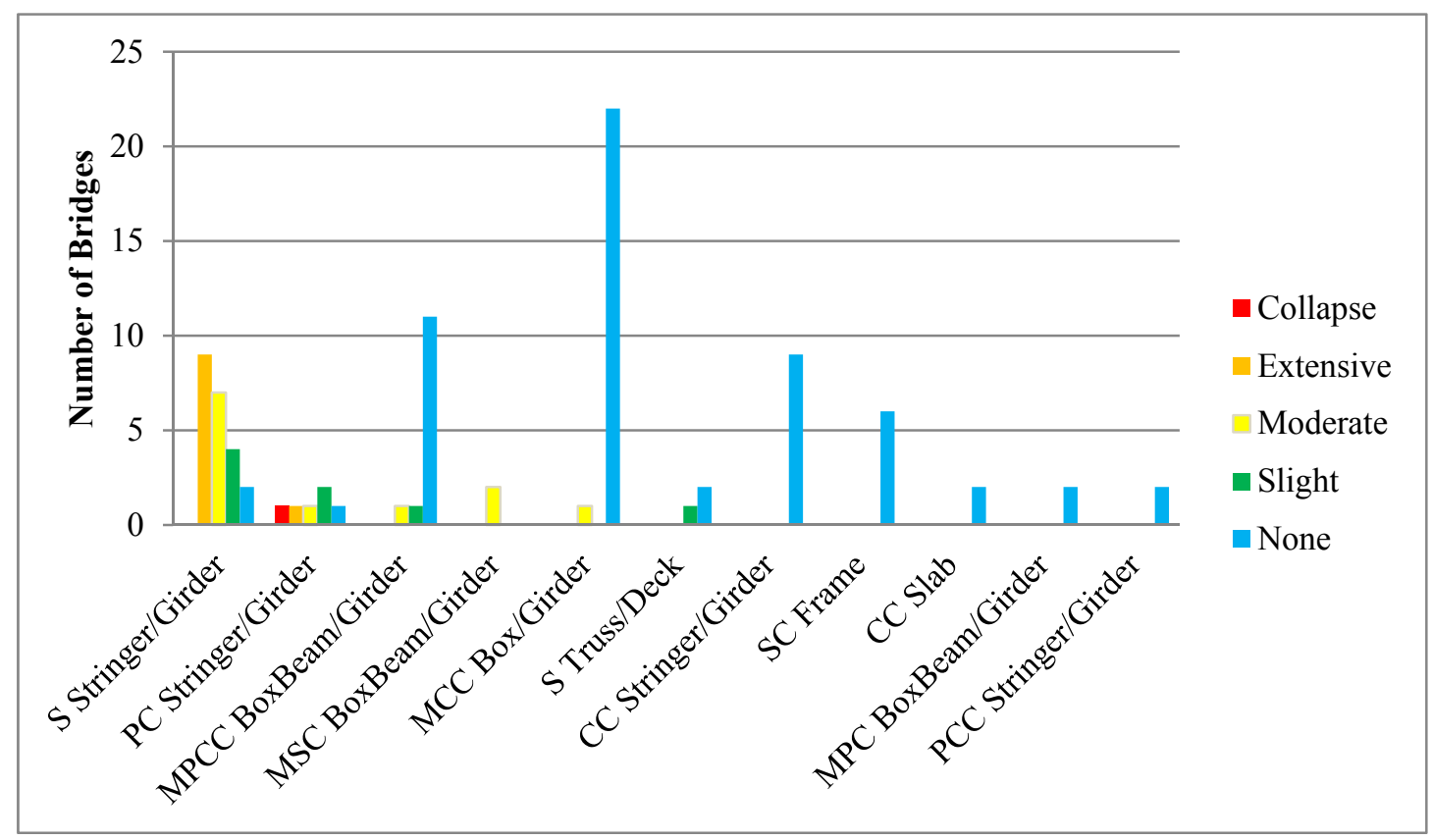

Figure C. 3: Hills M6.5 Scenario on I-5 from Multnomah to Clackamas County.

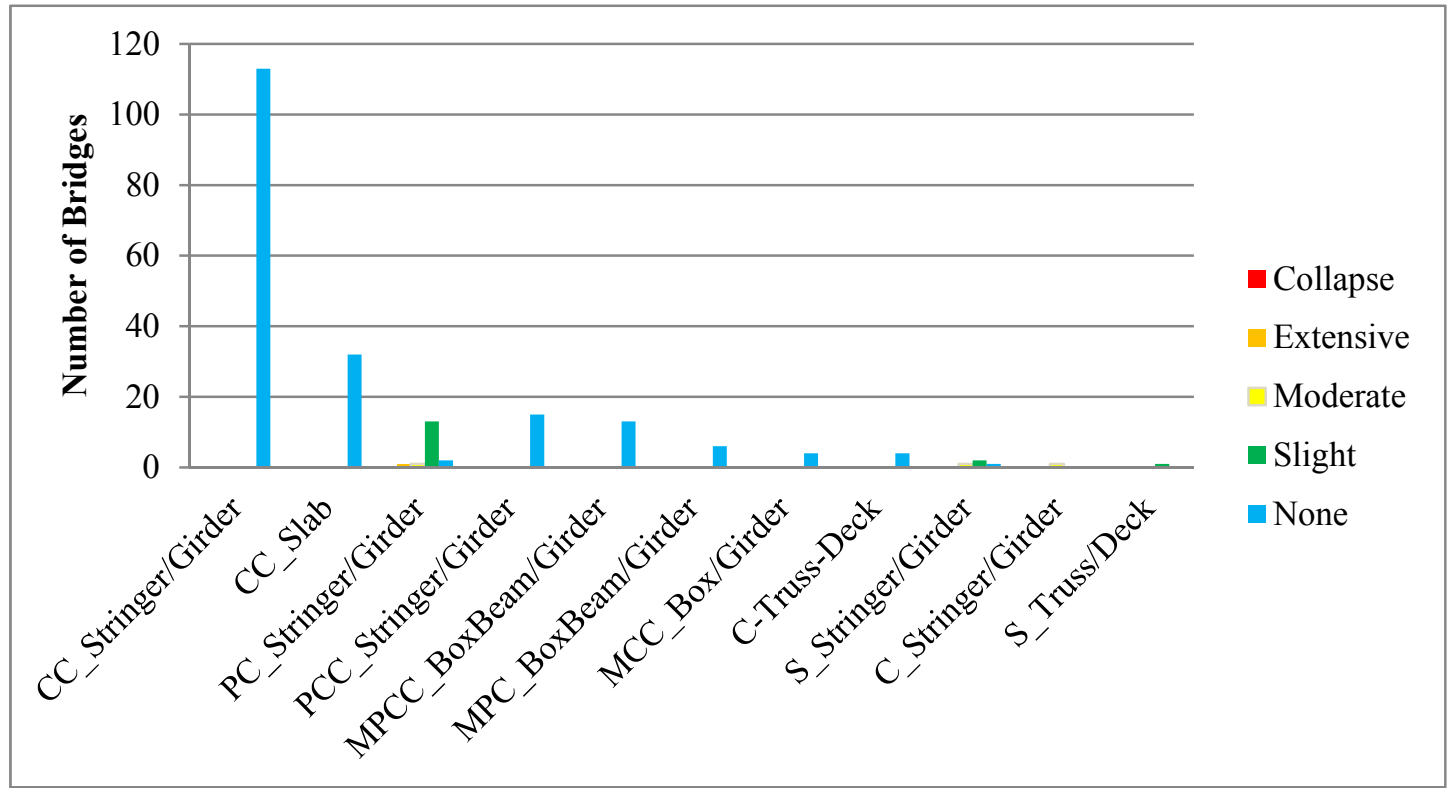

Figure C. 4: Cascadia M9.0 Scenario on I-5 from Marion to Lane County. 


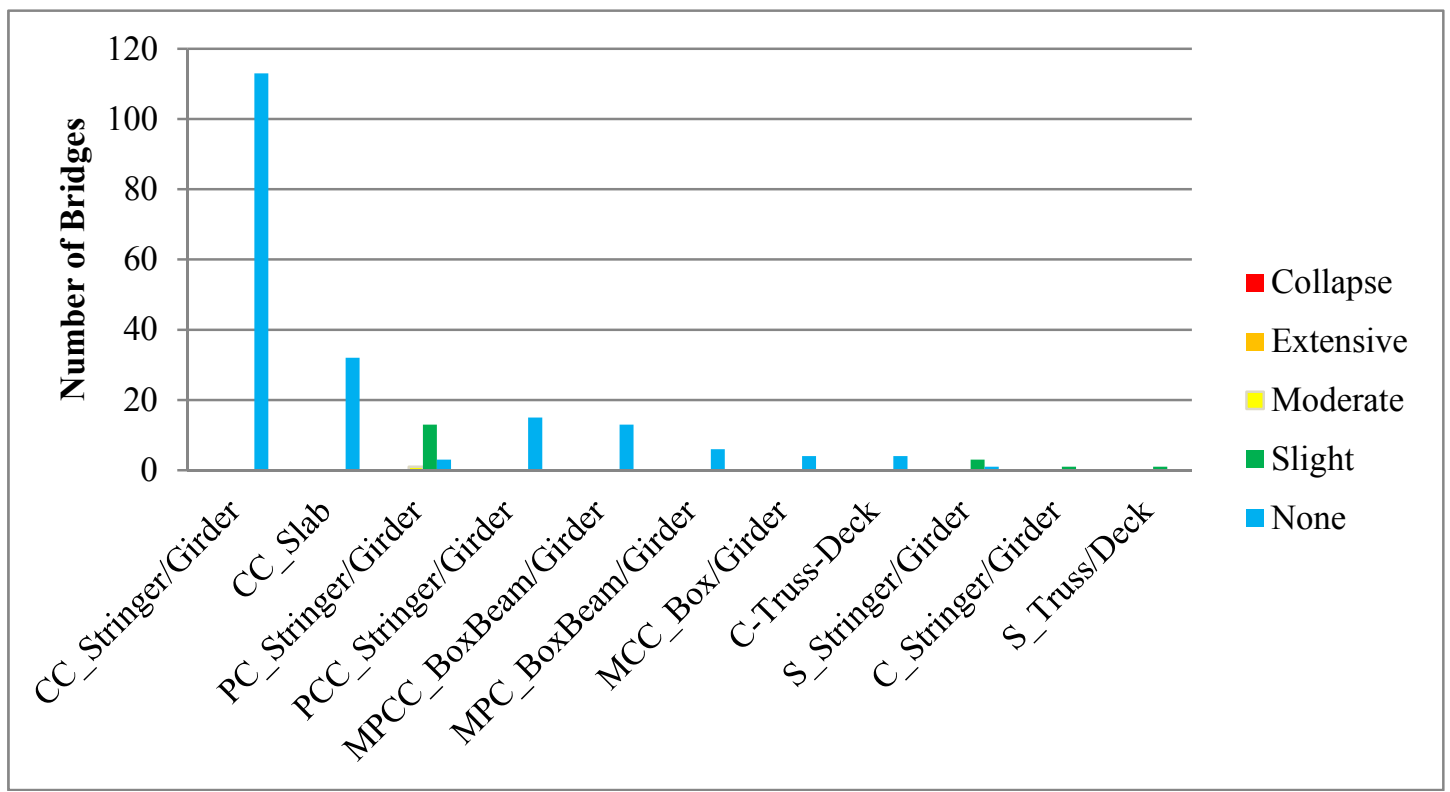

Figure C. 5: Cascadia North M8.3 Scenario on I-5 from Marion to Lane County.

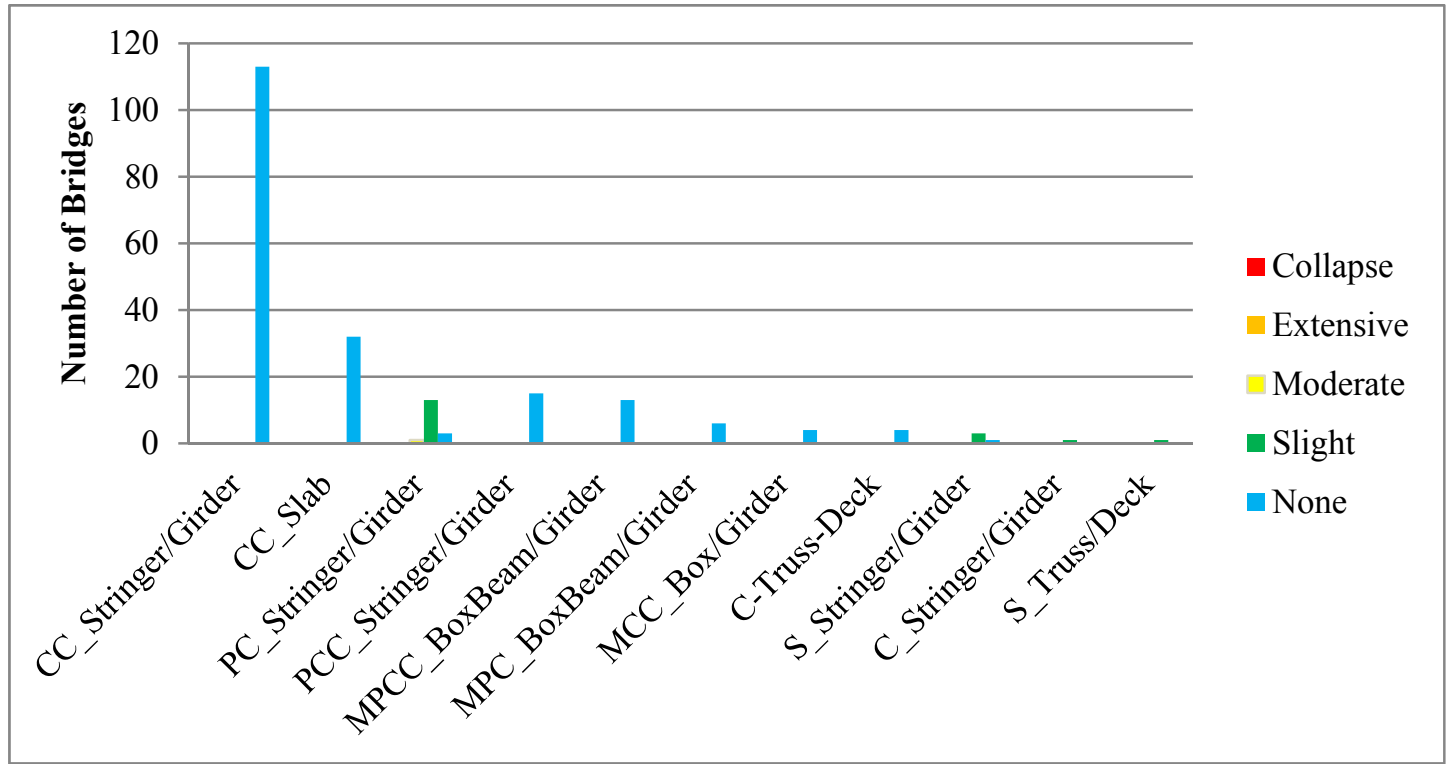

Figure C. 6: Cascadia South M8.3 Scenario on I-5 from Marion to Lane County. 


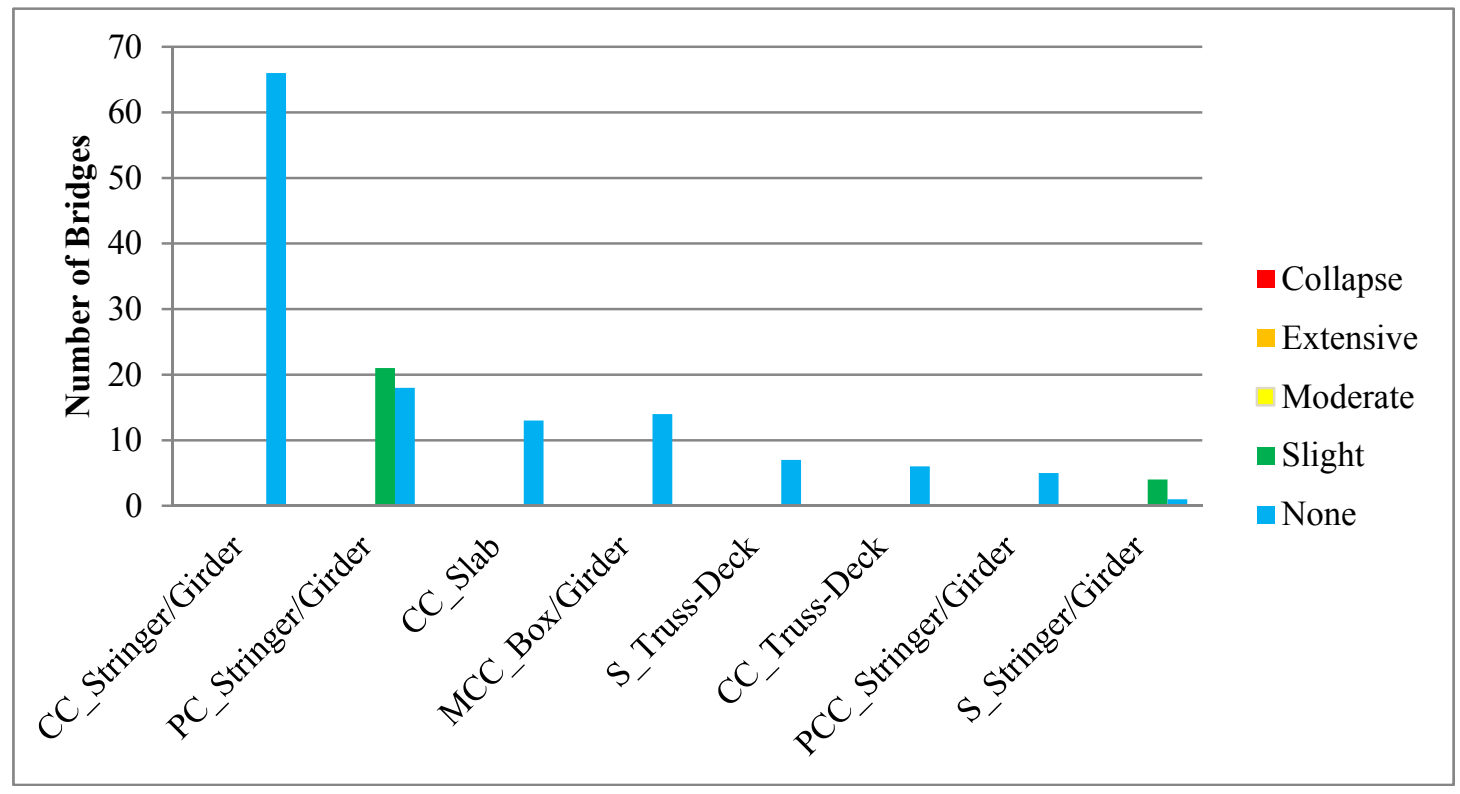

Figure C. 7: Cascadia M9.0 Scenario on I-5 from Douglas to Jackson County.

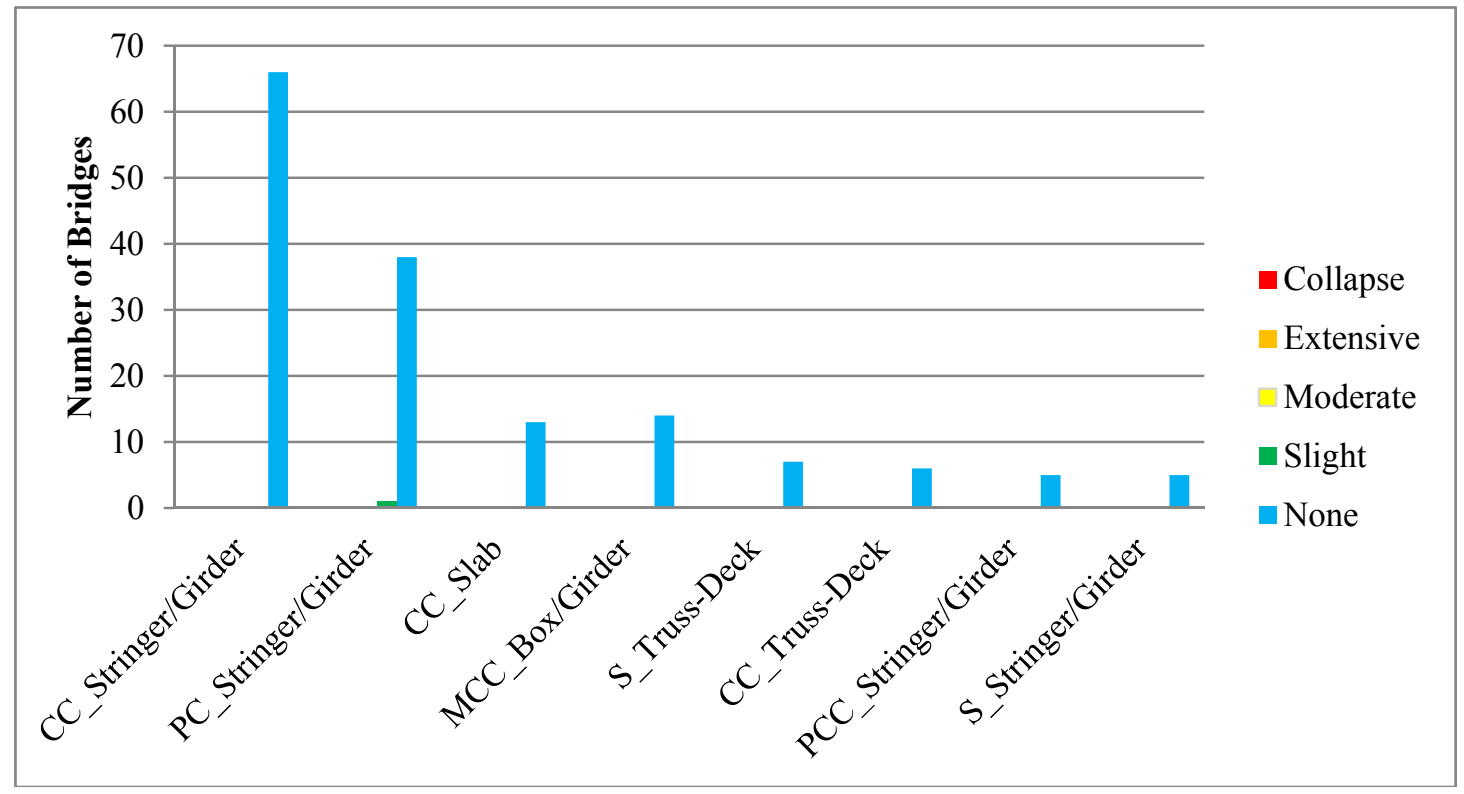

Figure C. 8: Cascadia North M8.3 Scenario on I-5 from Douglas to Jackson County. 


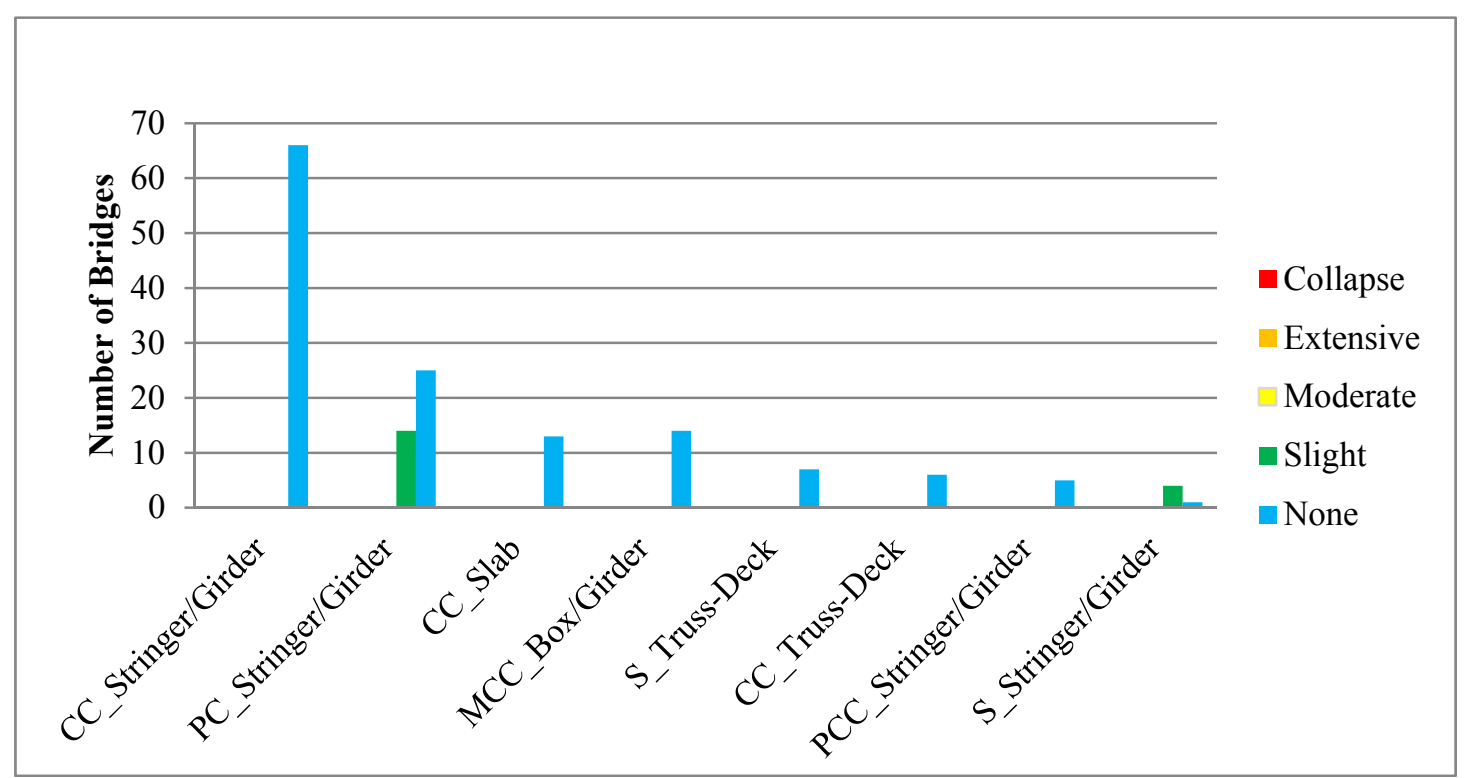

Figure C. 9: Cascadia South M8.3 Scenario on I-5 from Douglas to Jackson County.

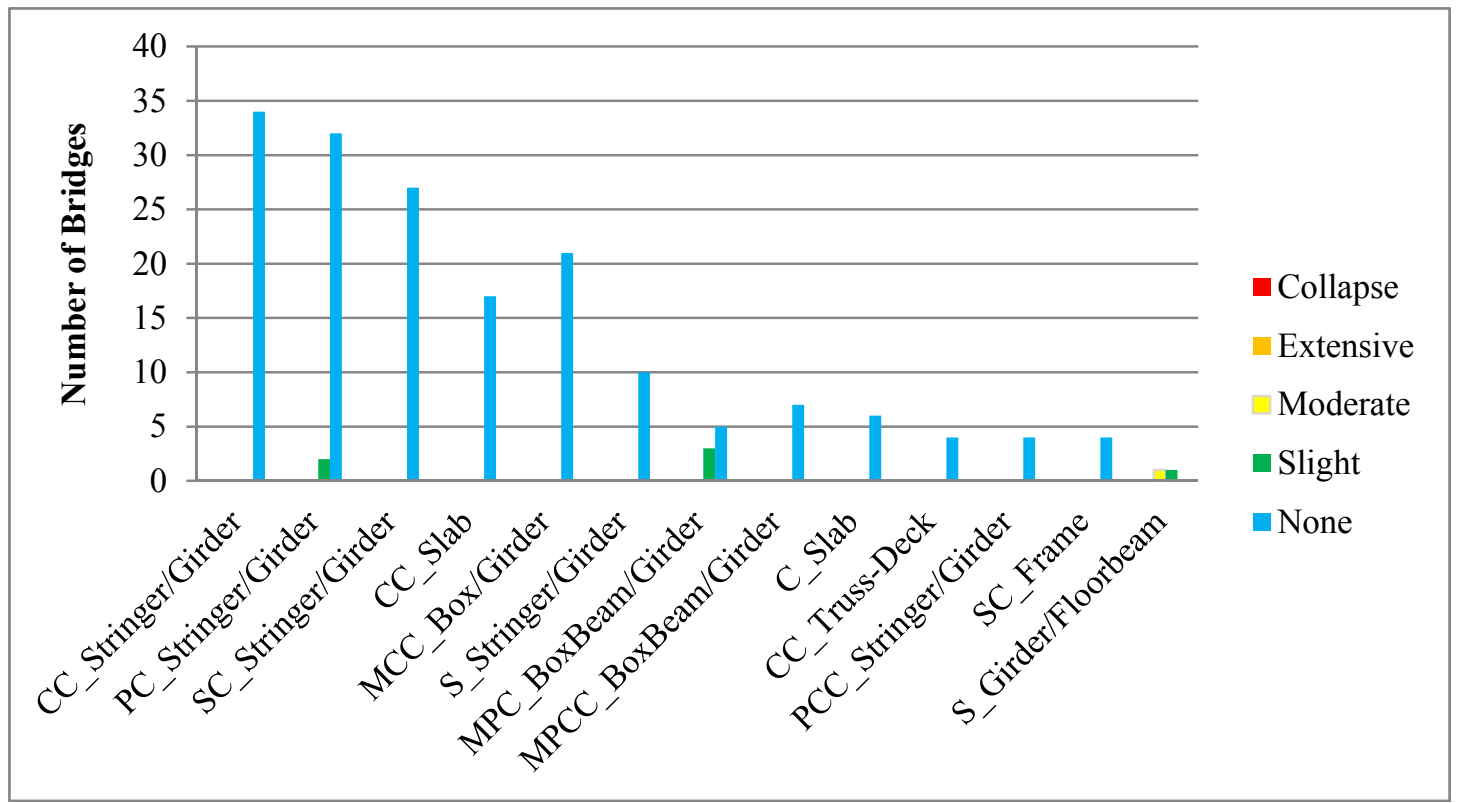

Figure C. 10: Cascadia M9.0 Scenario on I-84. 


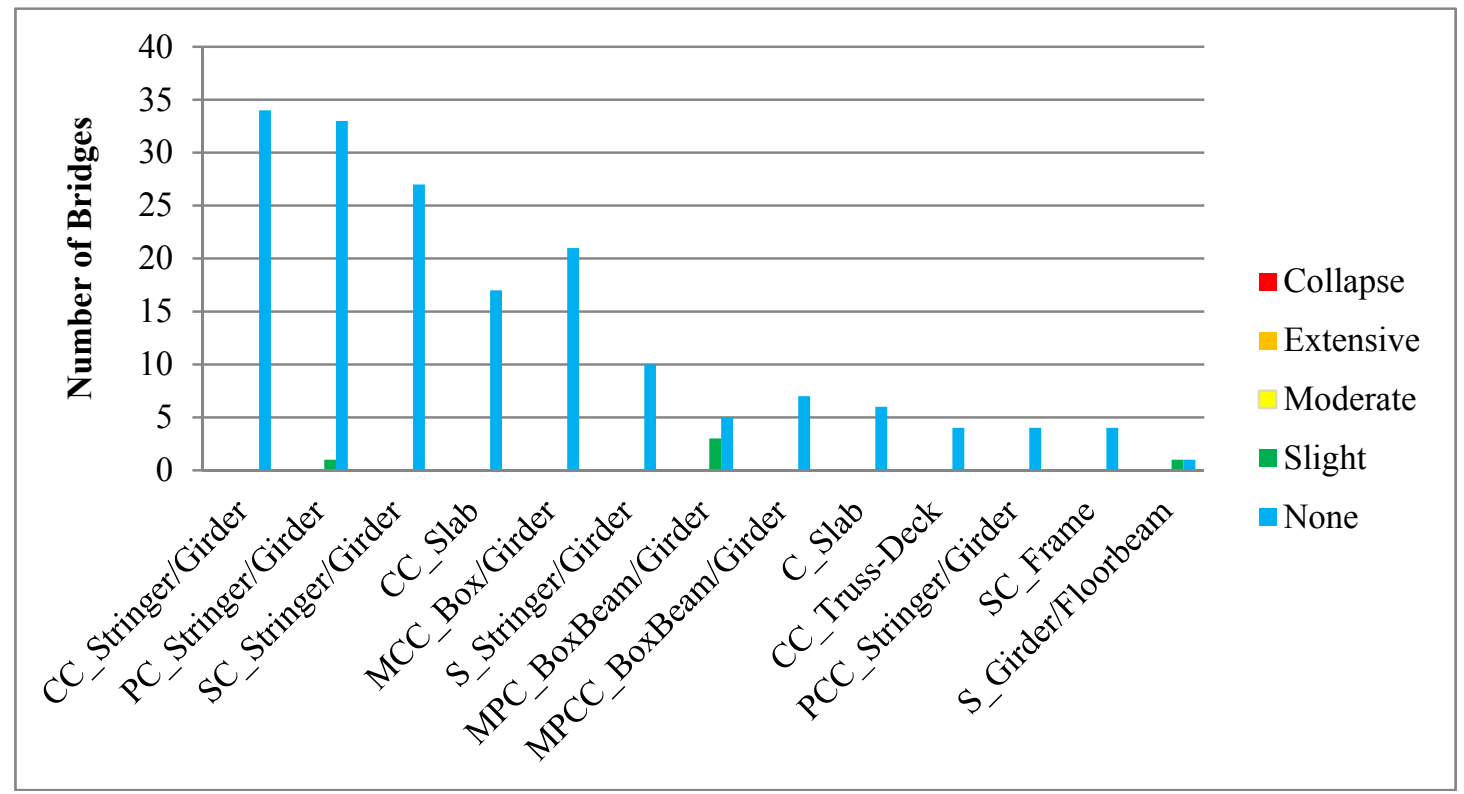

Figure C. 11: Cascadia North M8.3 Scenario on I-84.

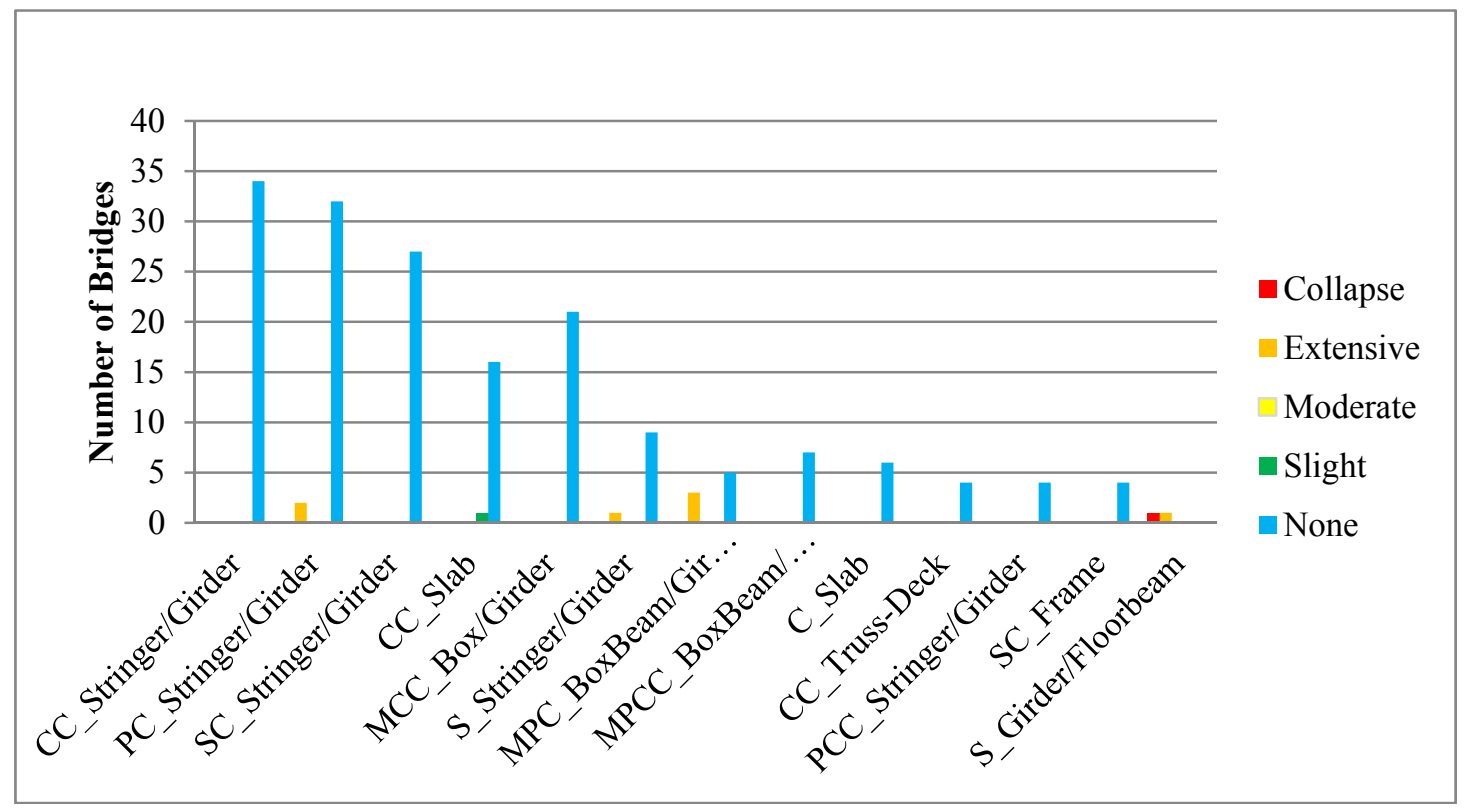

Figure C. 12: Portland Hills M6.5 Scenario on I-84. 


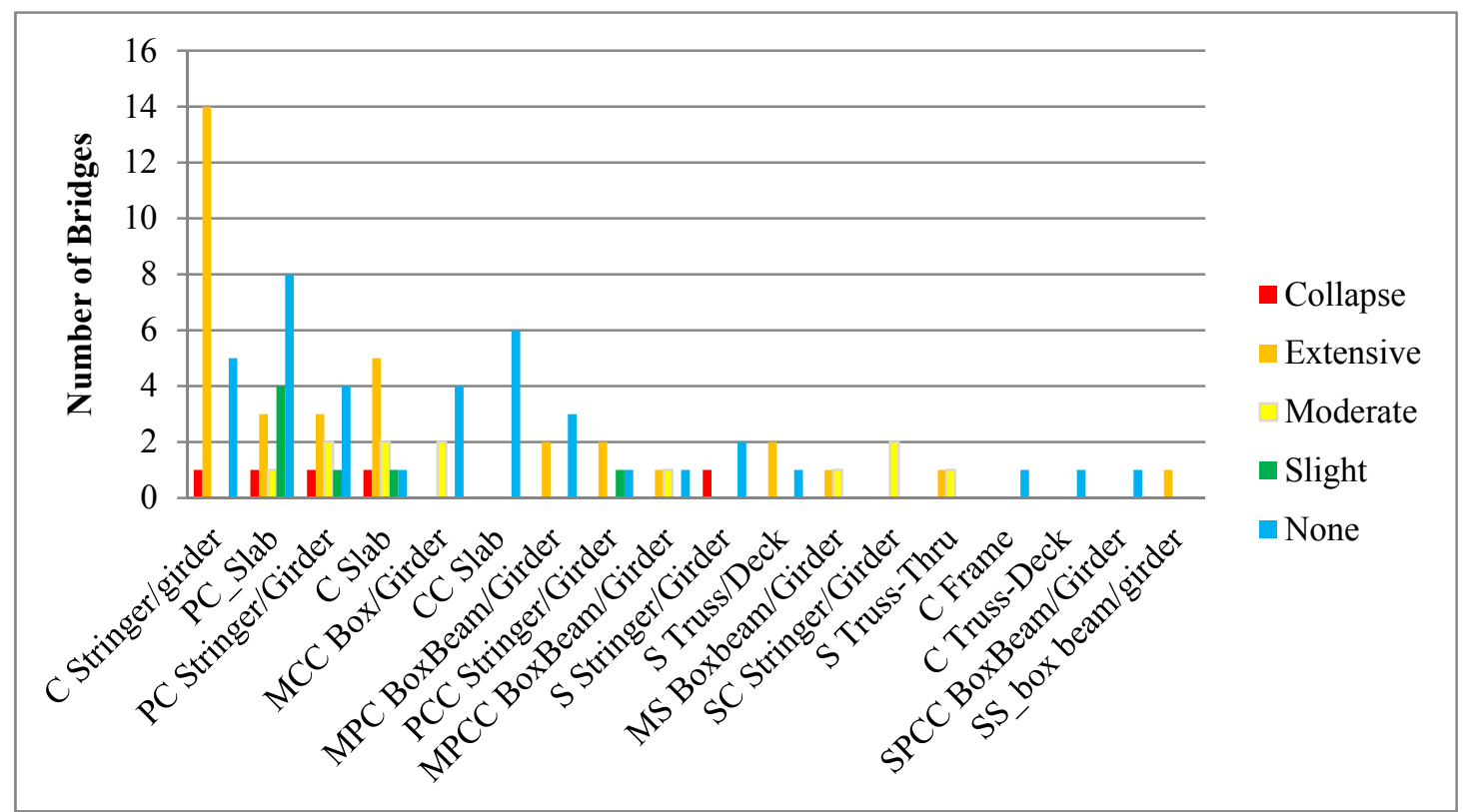

Figure C. 13: Cascadia M9.0 Scenario on US 101.

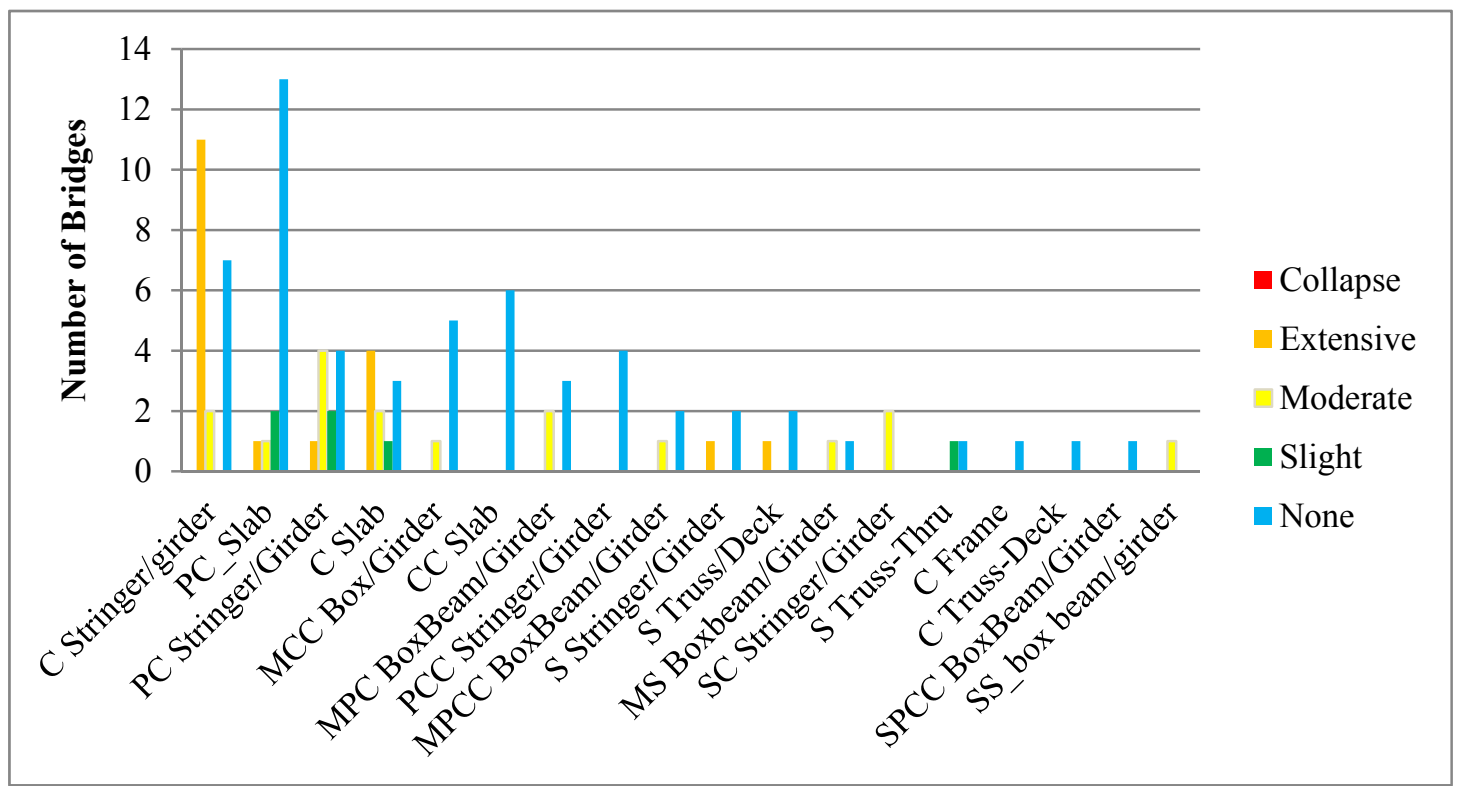

Figure C. 14: Cascadia North M8.3 Scenario on US 101 


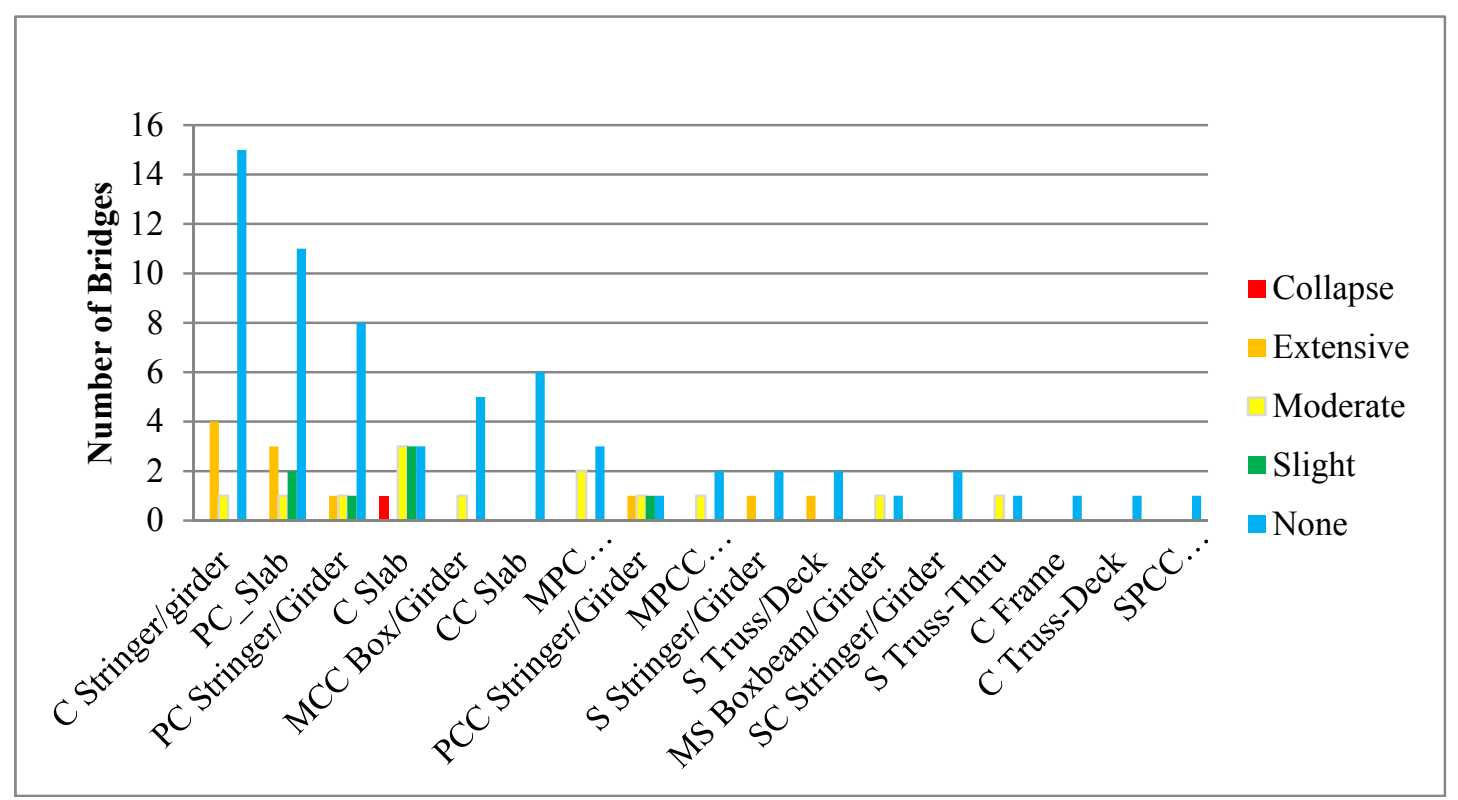

Figure C. 15: Cascadia South M8.3 Scenario on US 101.

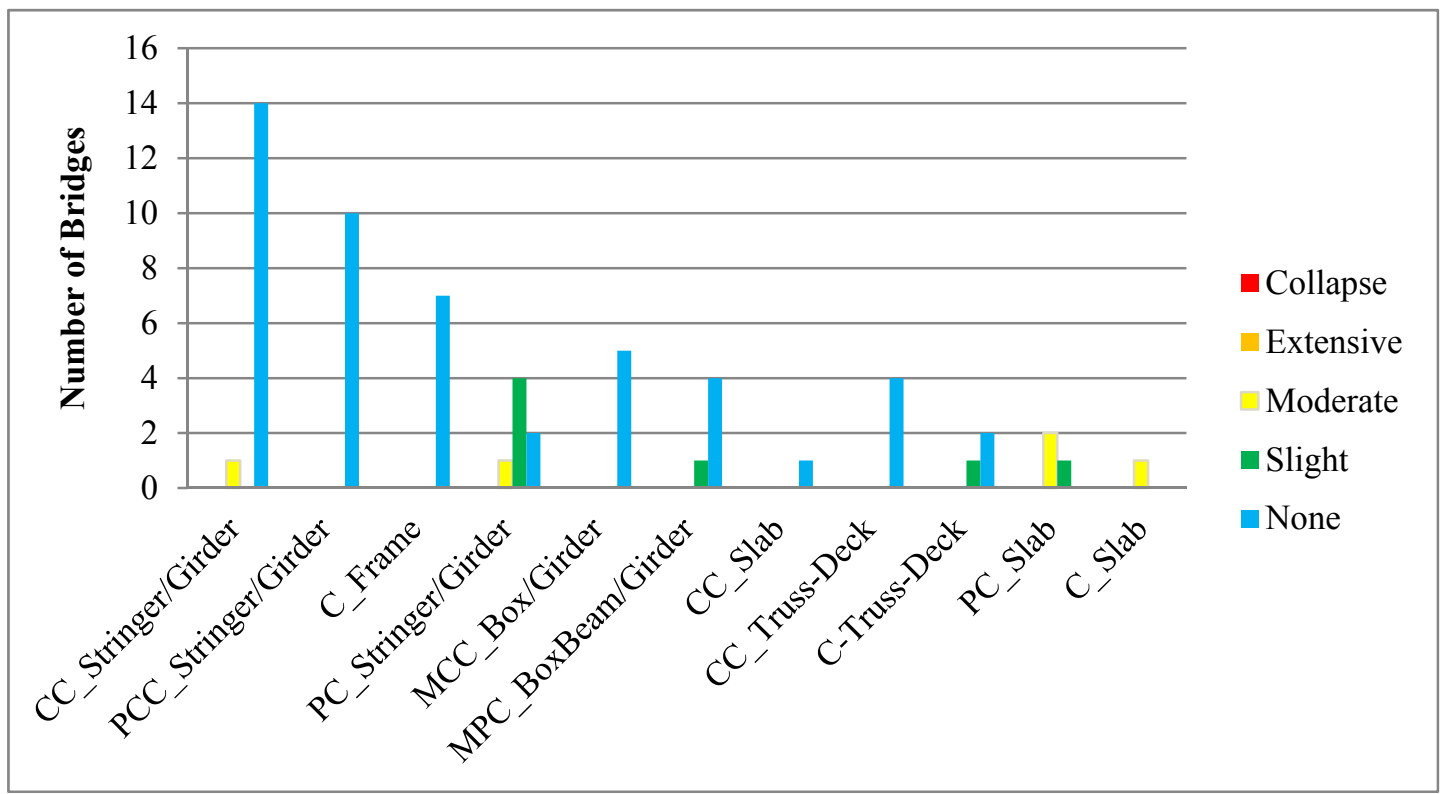

Figure C. 16: Cascadia M9.0 Scenario on US 26. 


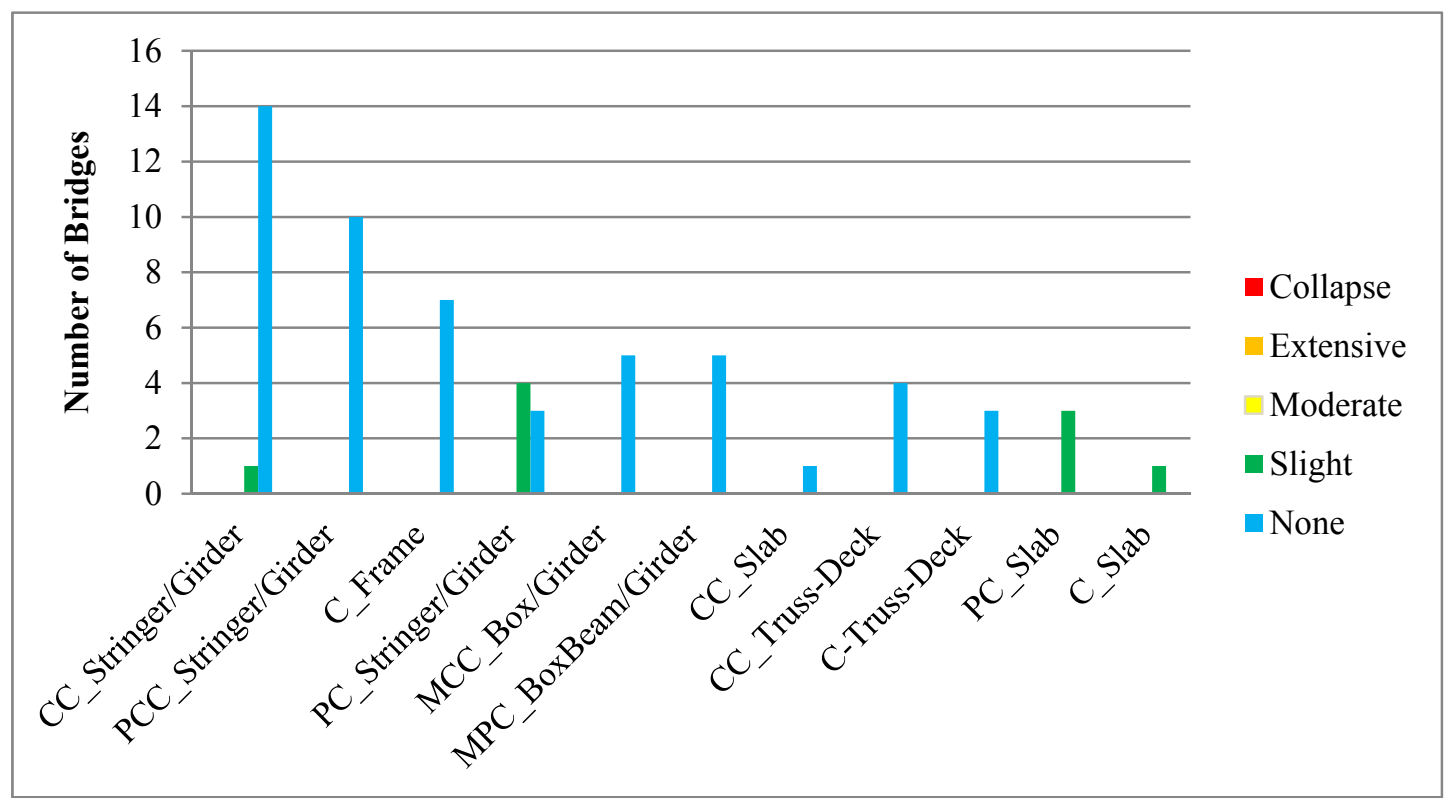

Figure C. 17: Cascadia North M8.3 Scenario on US 26.

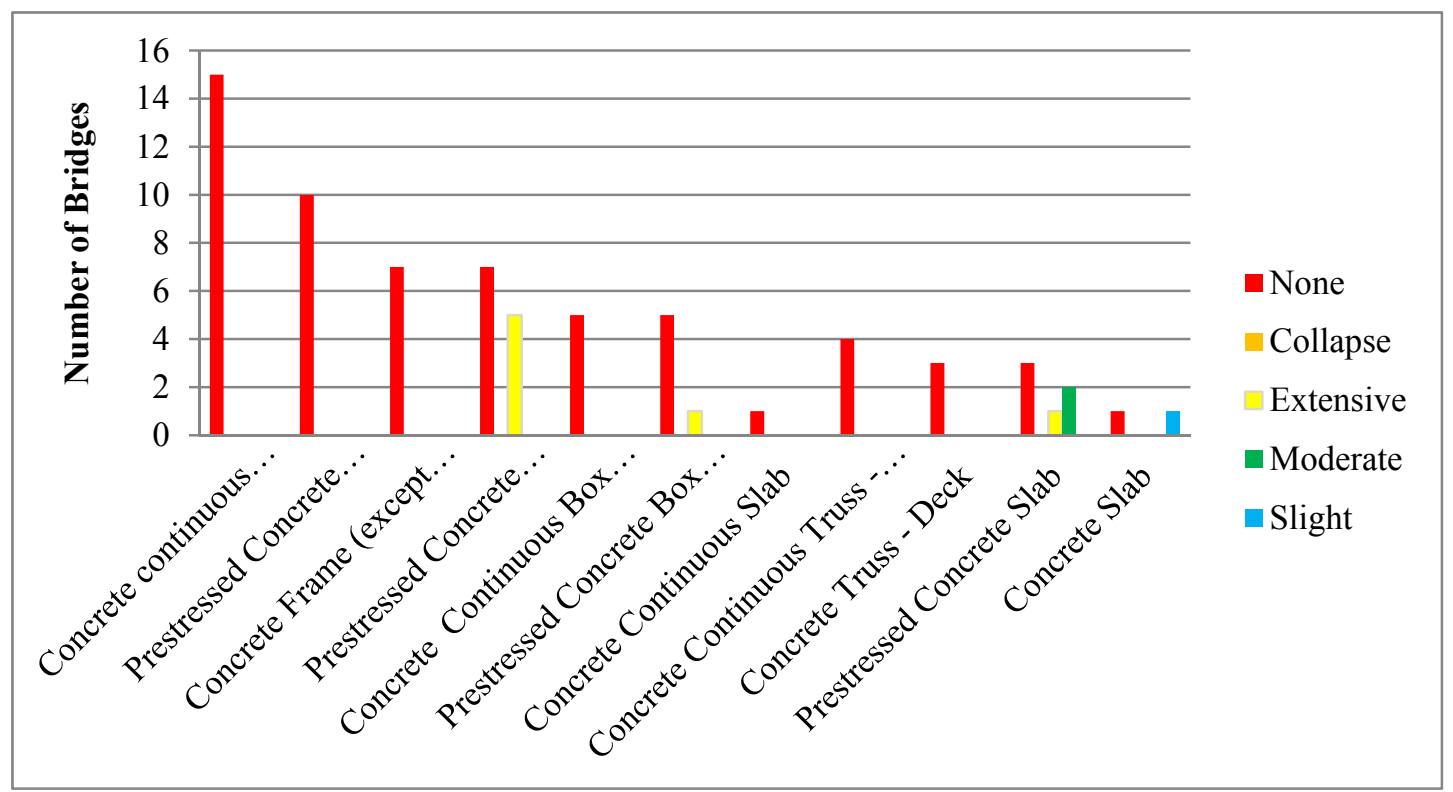

Figure C. 18: Portland Hills M6.5 Scenario on US 26. 


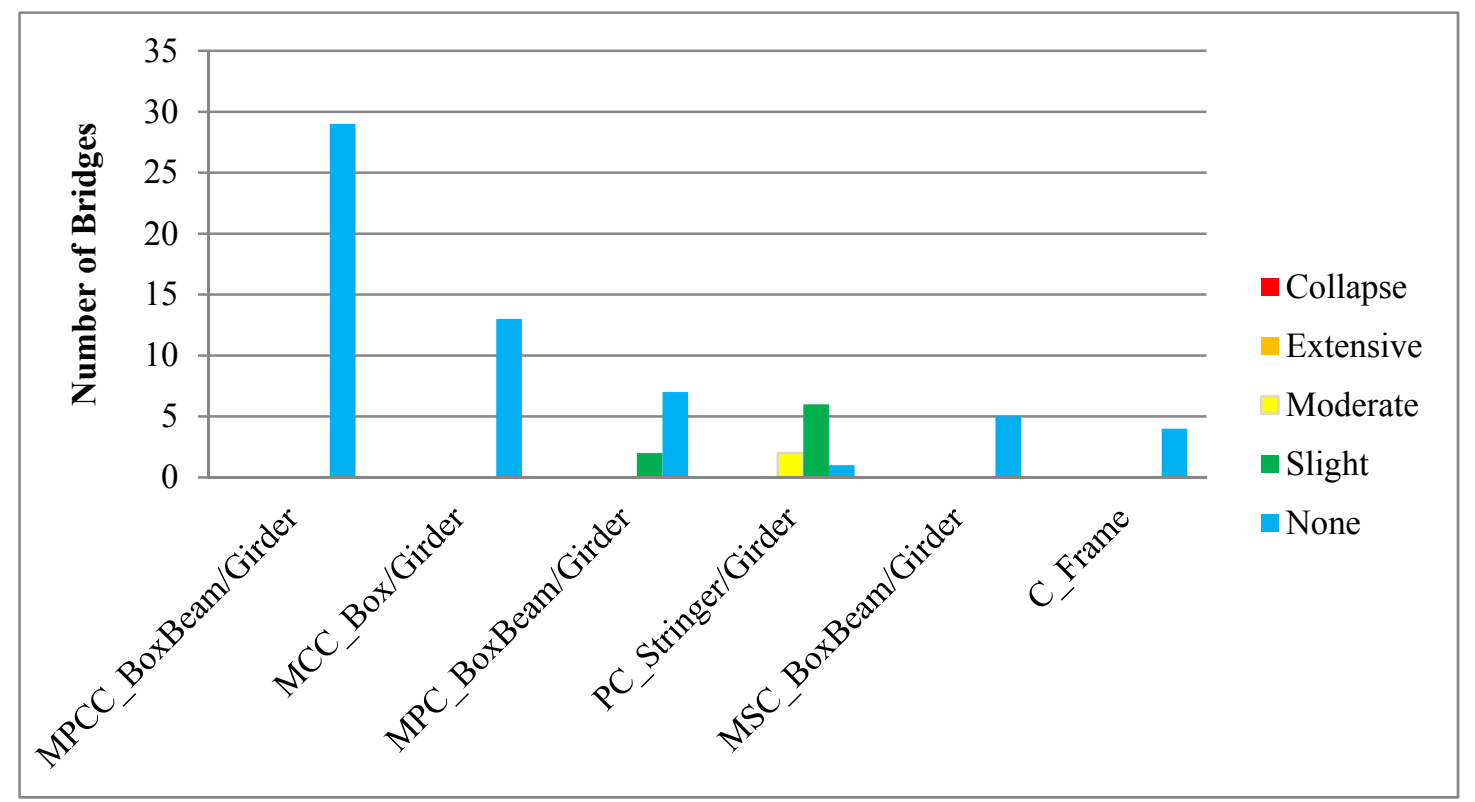

Figure C. 19: Cascadia M9.0 Scenario on I-205.

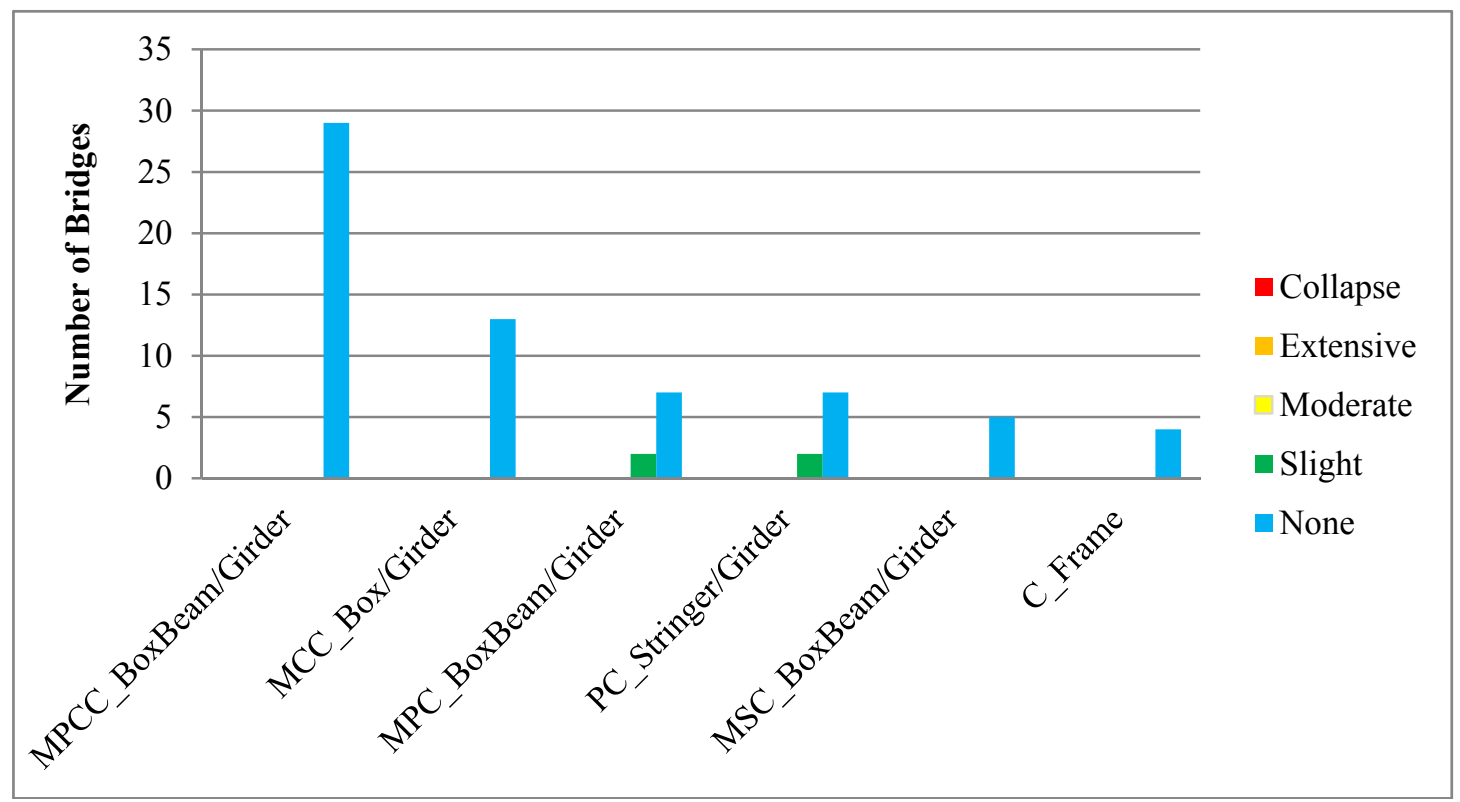

Figure C. 20: Cascadia North M8.3 Scenario on I-205. 


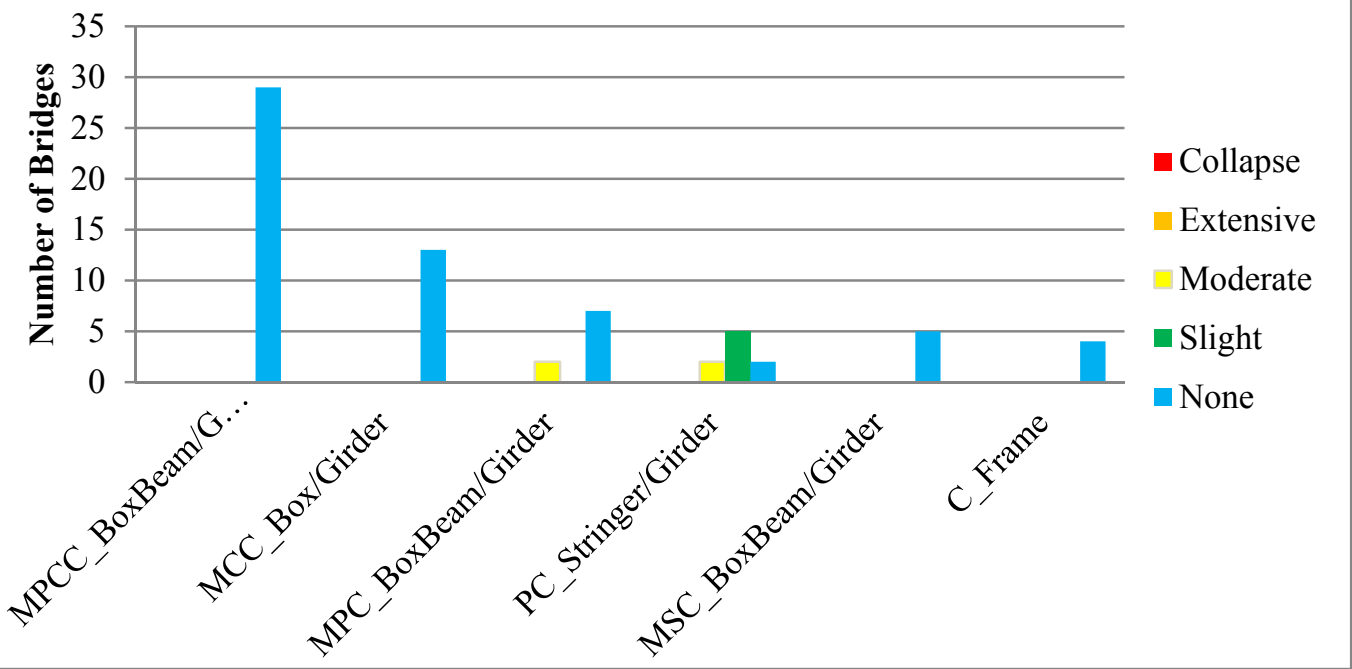

Figure C. 21: Portland Hills M6.5 Scenario on I-205.

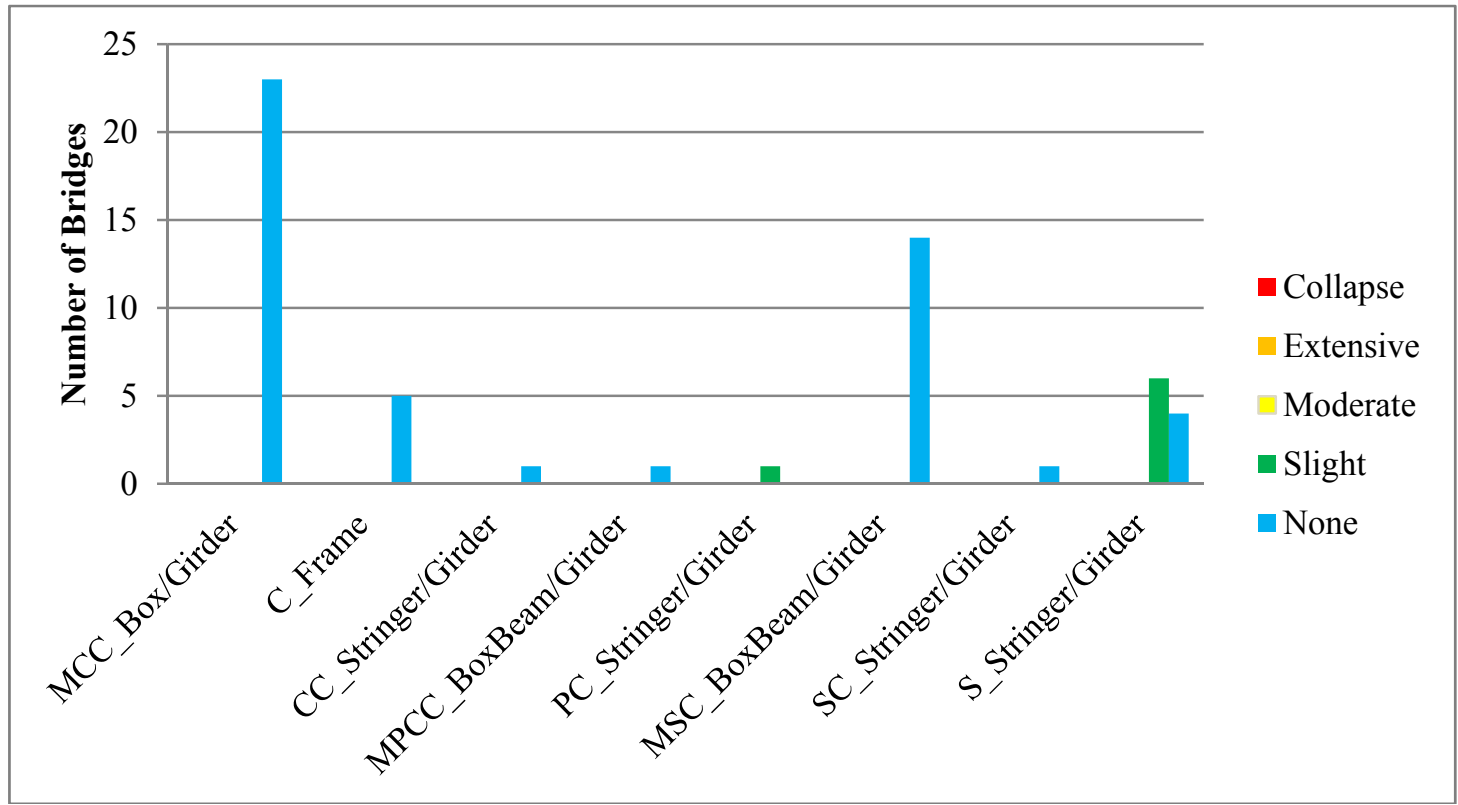

Figure C. 22: Cascadia M9.0 Scenario on I-405. 


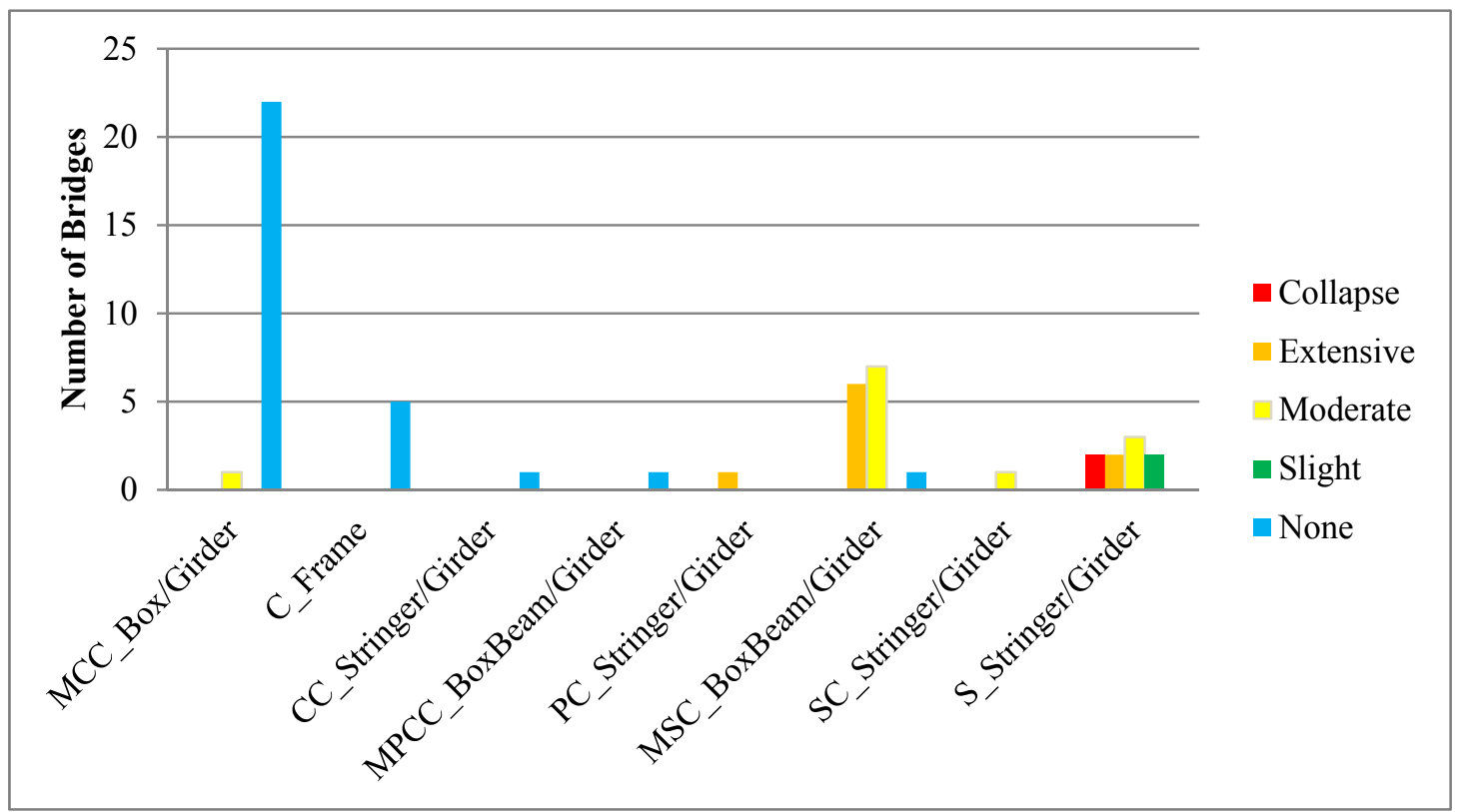

Figure C. 23: Portland Hills M6.5 Scenario on I-405.

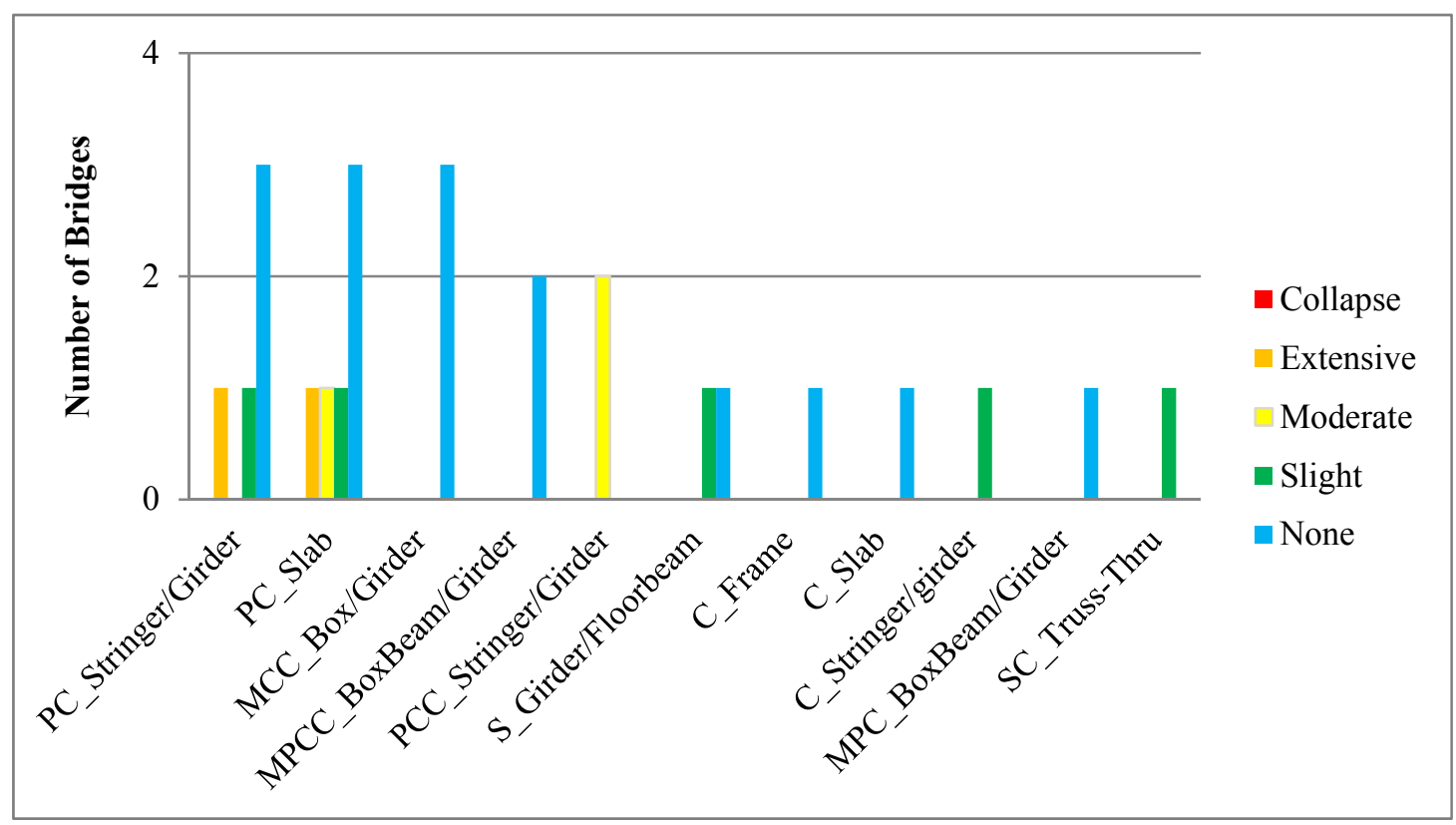

Figure C. 24: Cascadia M9.0 Scenario on US 30. 


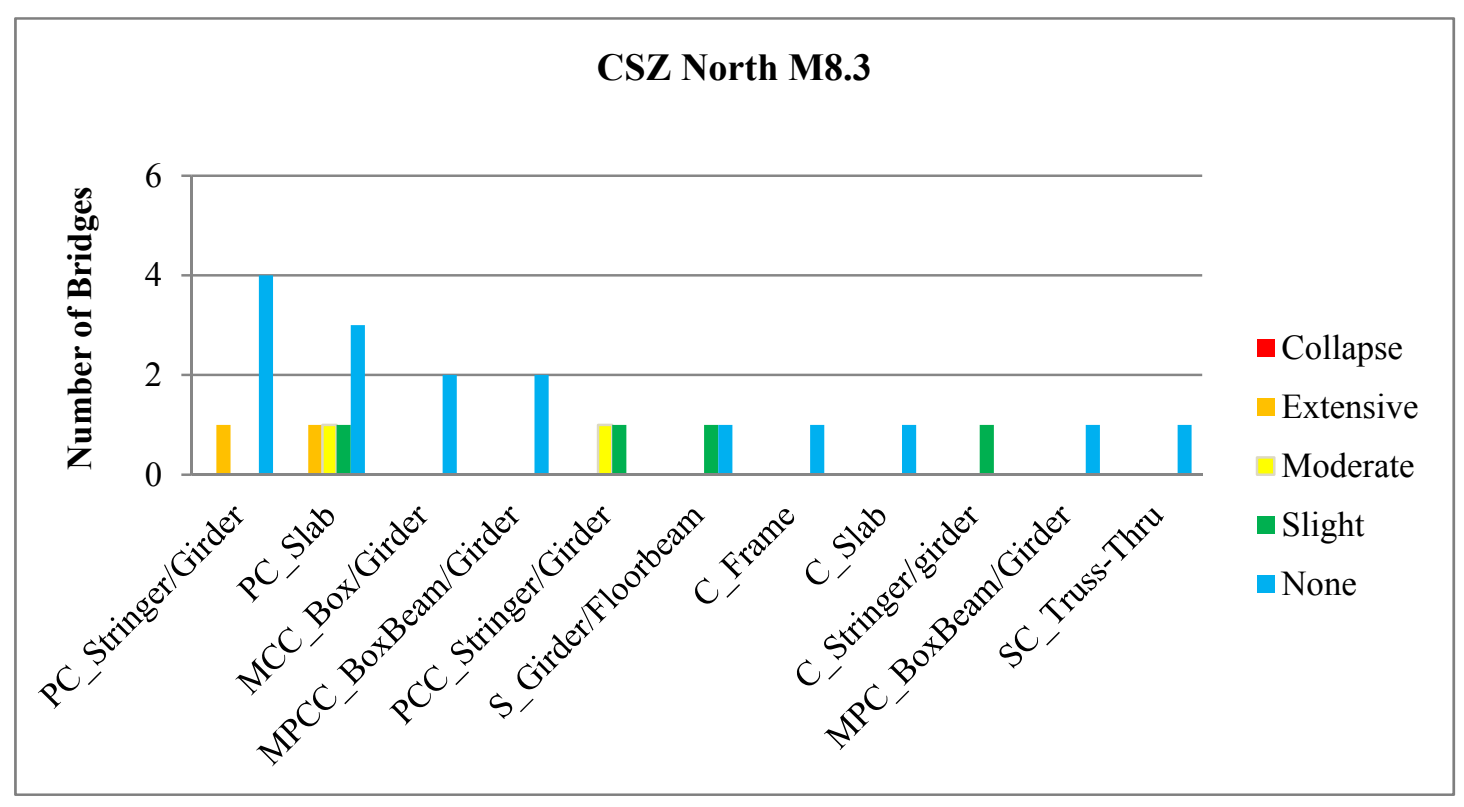

Figure C. 25: Cascadia North M8.3 Scenario on US 30.

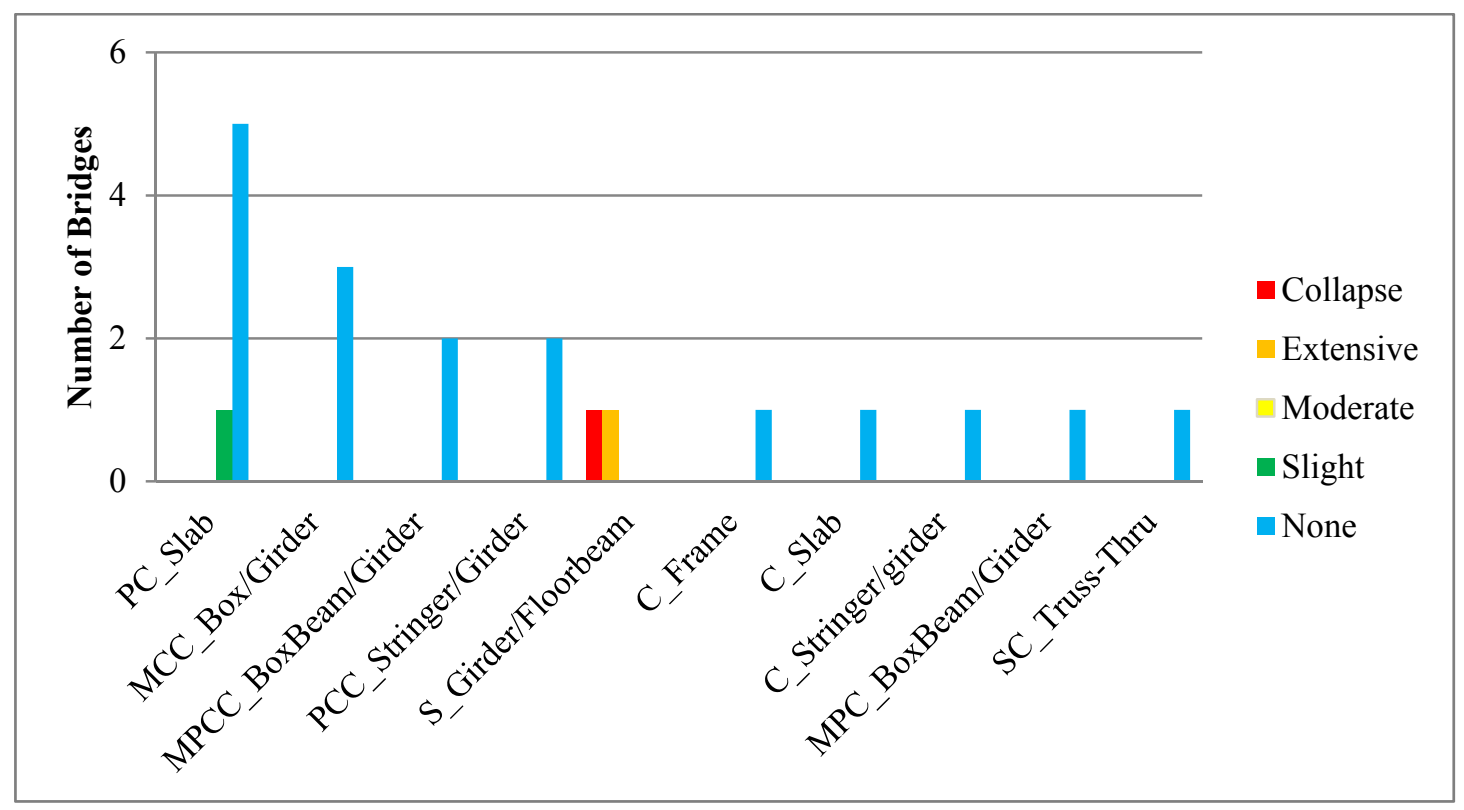

Figure C. 26: Portland Hills M6.5 Scenario on US 30. 


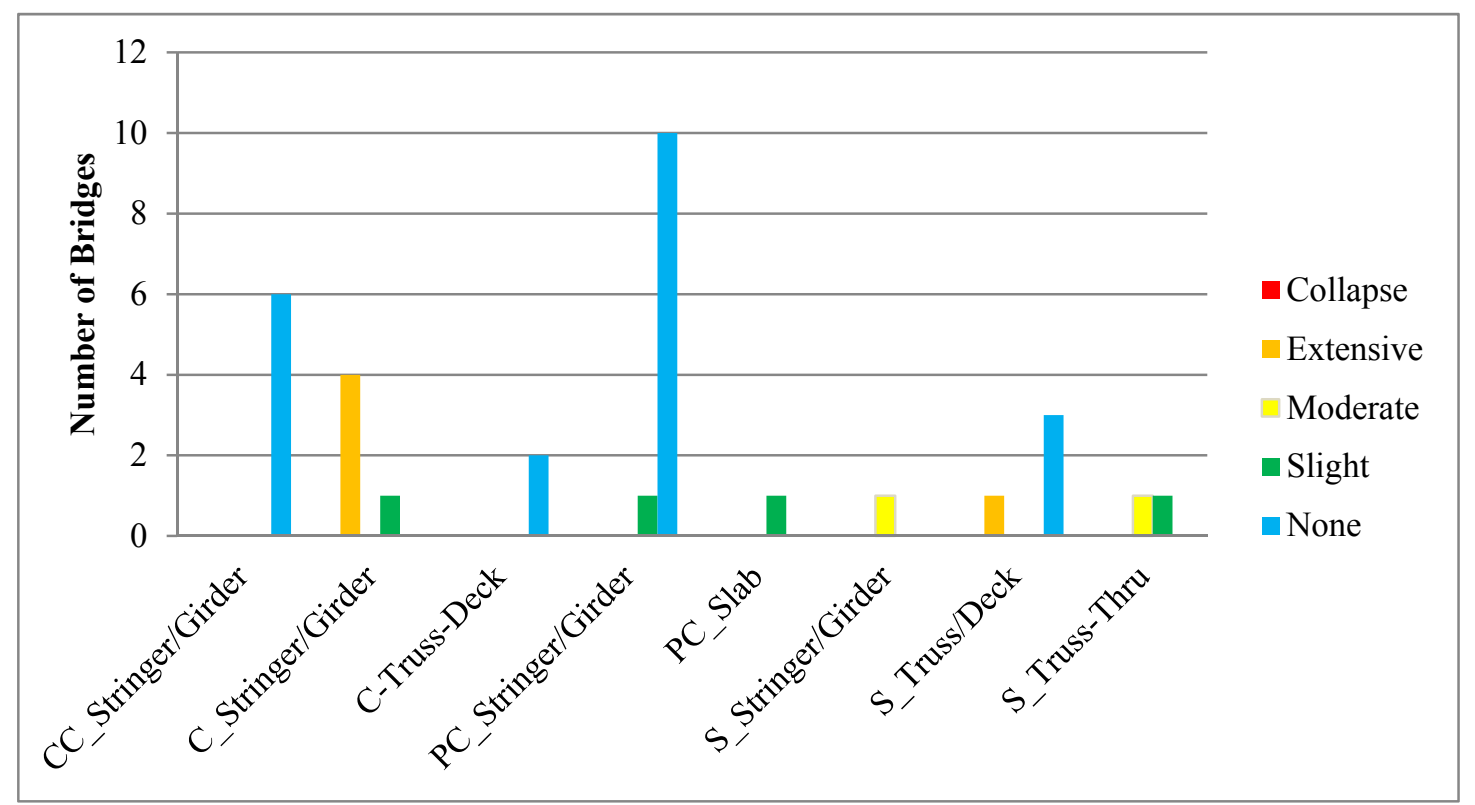

Figure C. 27: Cascadia M9.0 Scenario on US 20.

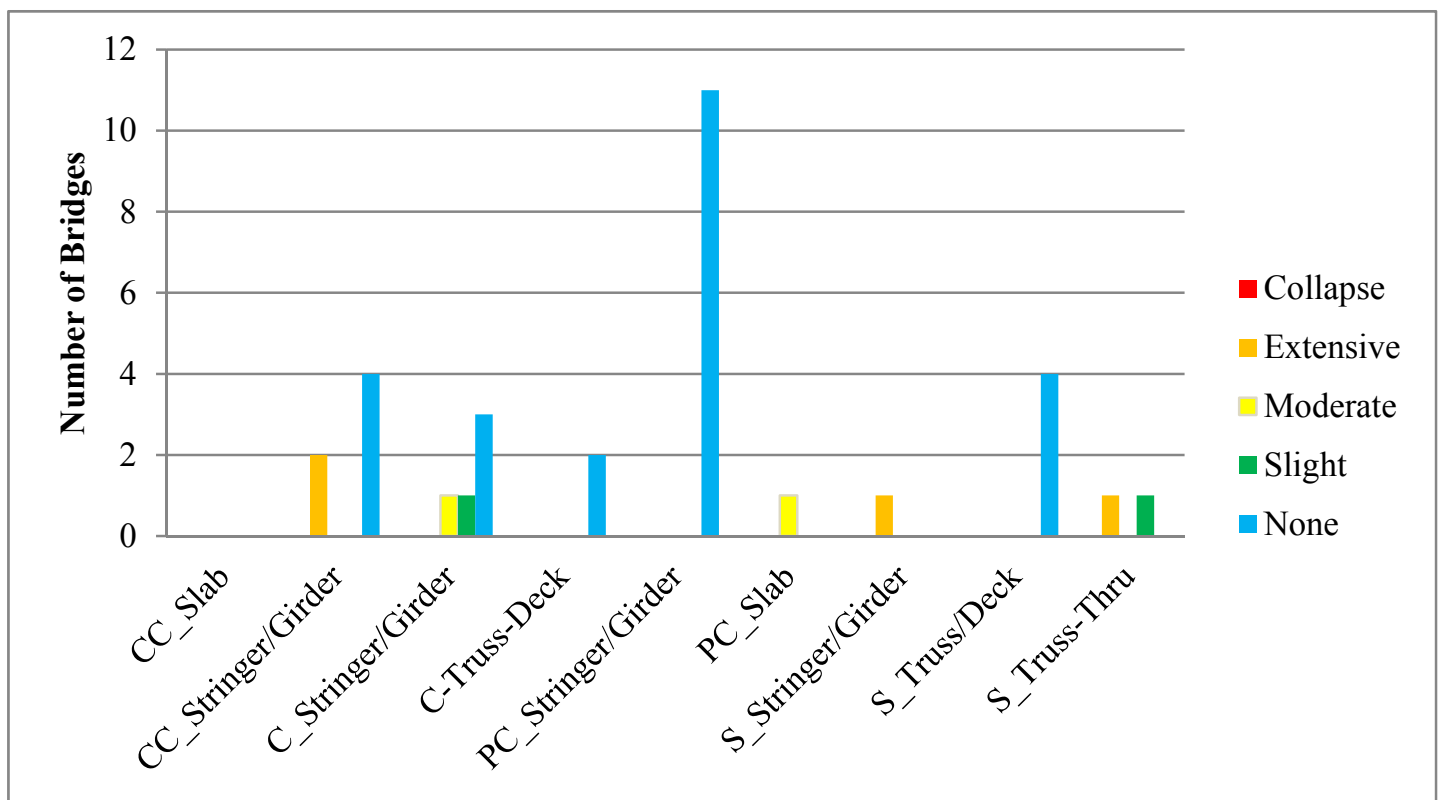

Figure C. 28: Cascadia North M8.3 Scenario on US 20. 


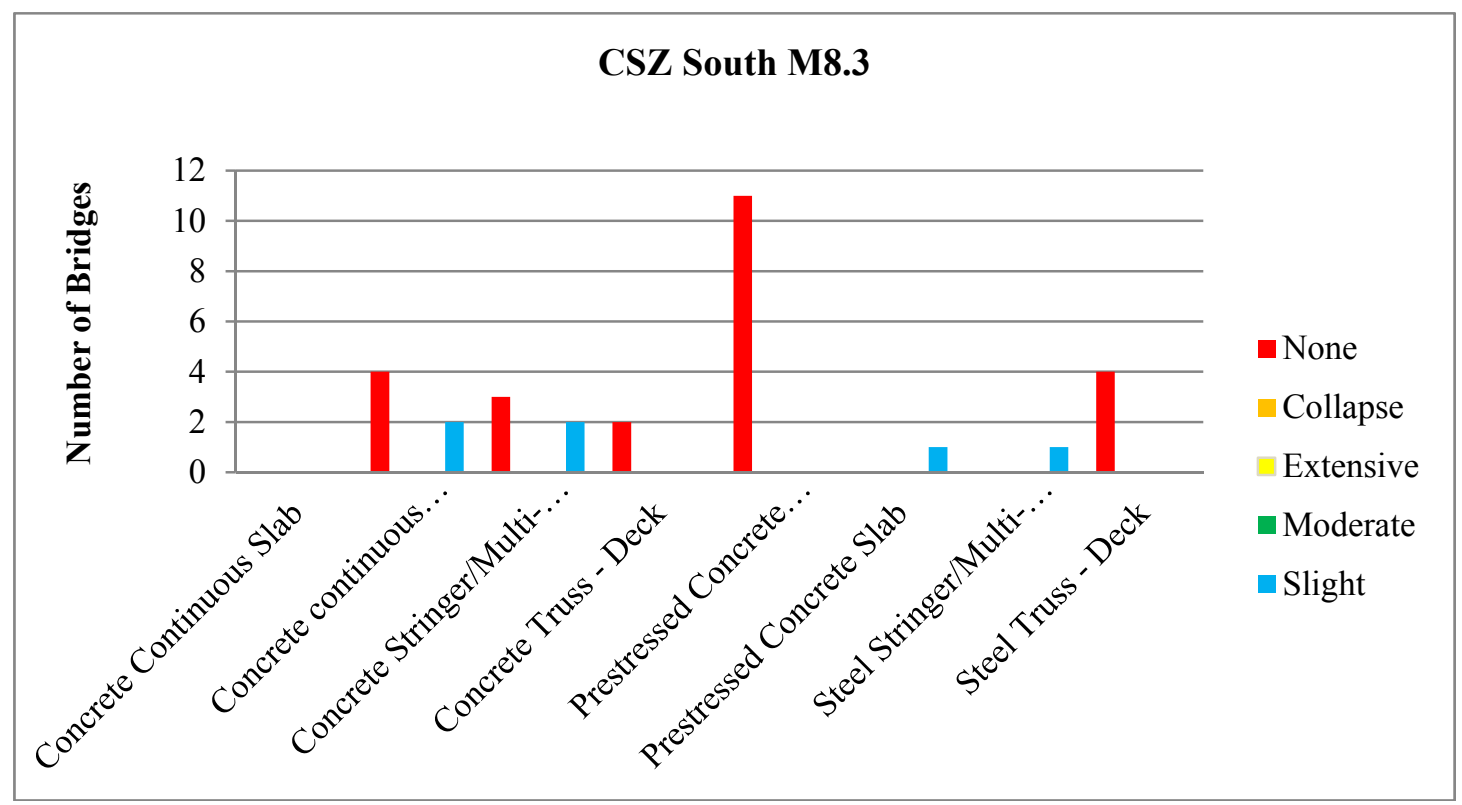

Figure C. 29: Cascadia South M8.3 Scenario on US 20.

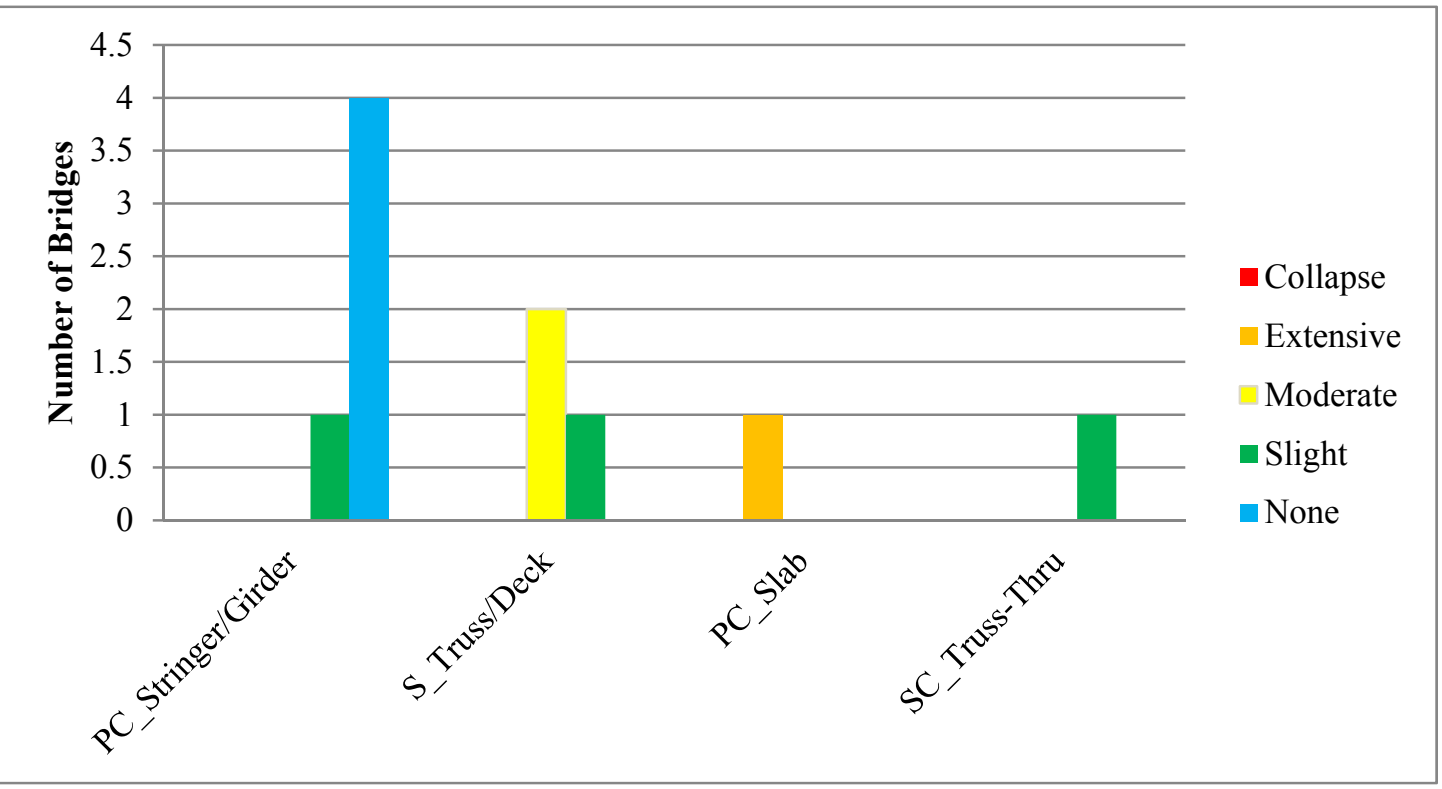

Figure C. 30: Cascadia M9.0 Scenario on OR 38. 


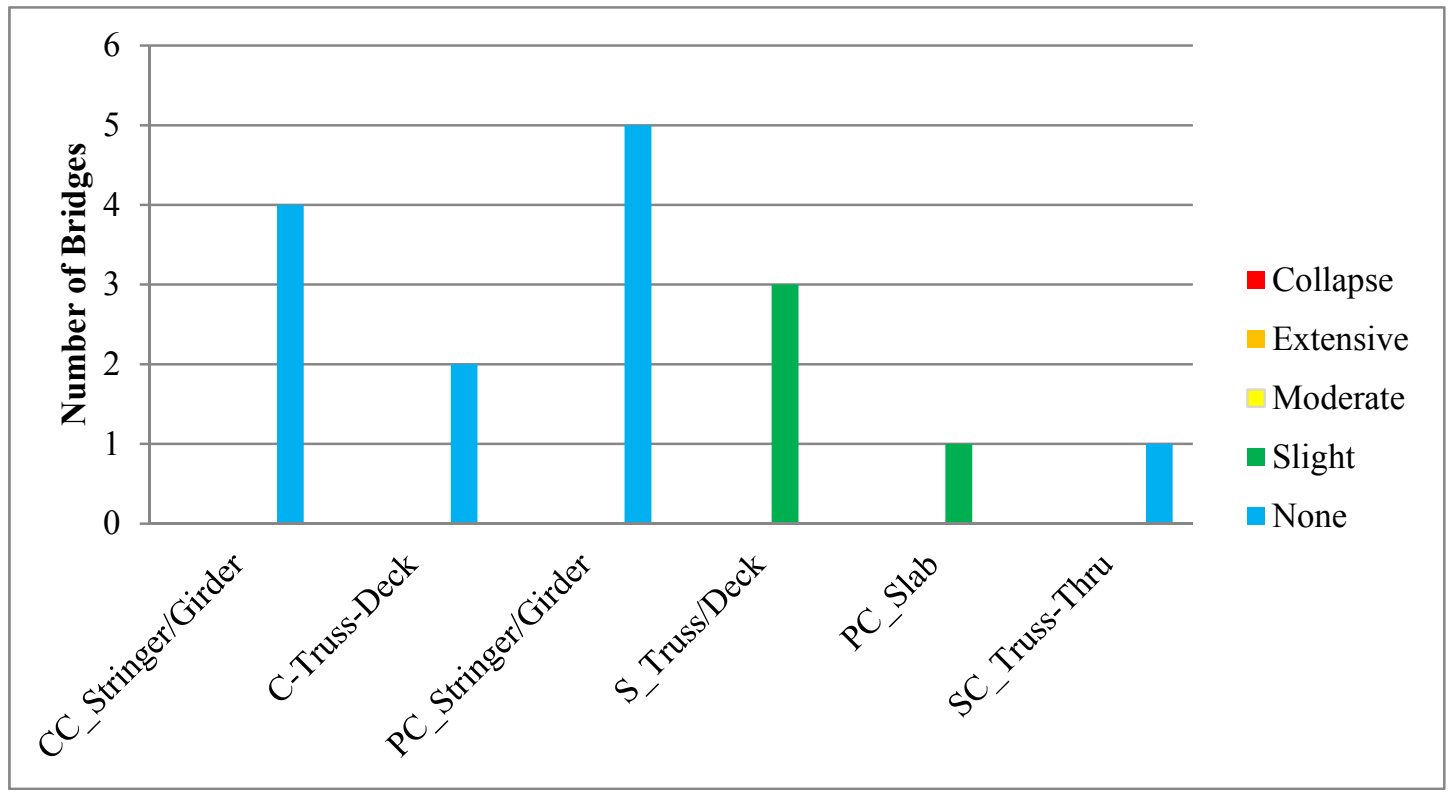

Figure C. 31: Cascadia North M8.3 Scenario on OR 38.

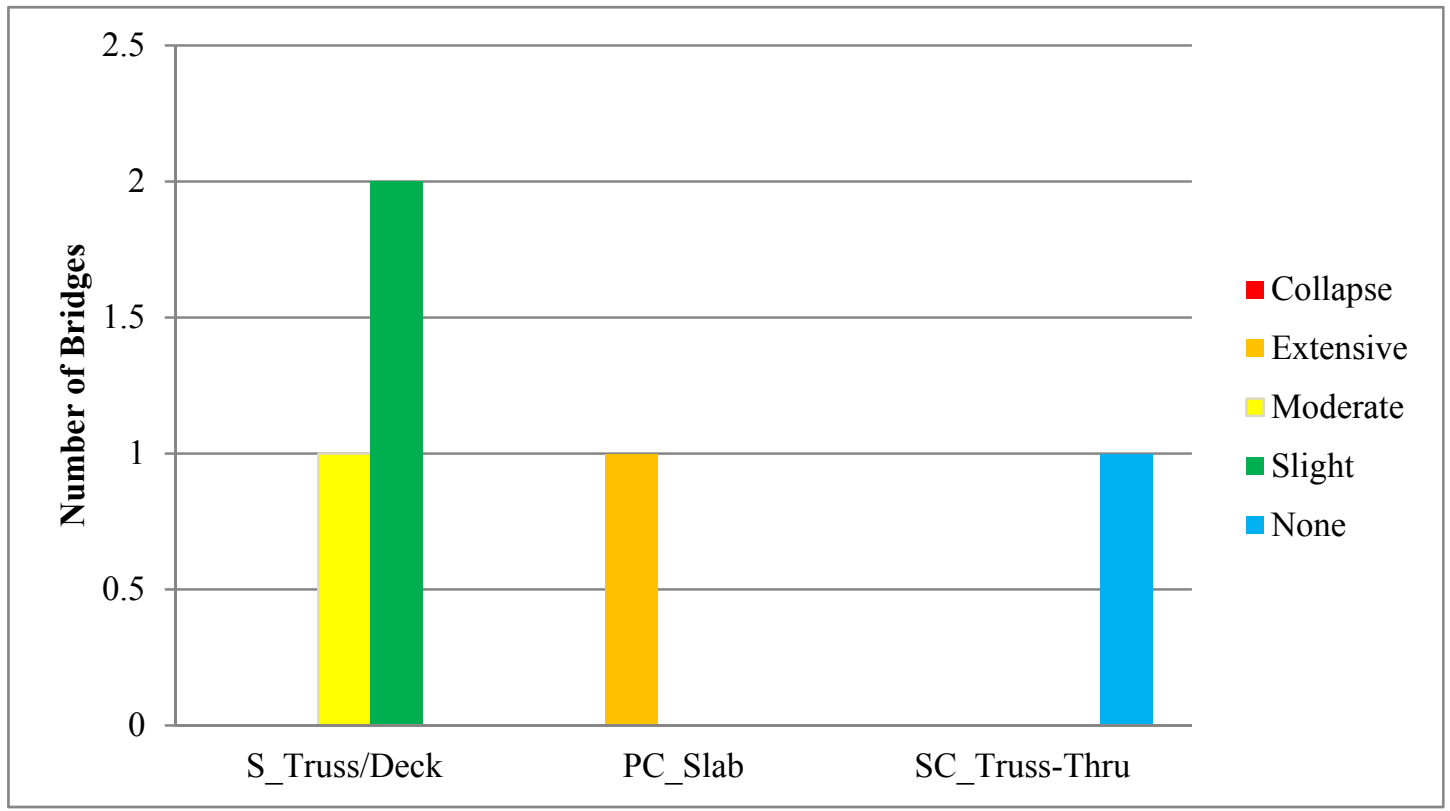

Figure C. 32: Cascadia South M8.3 Scenario on OR 38. 


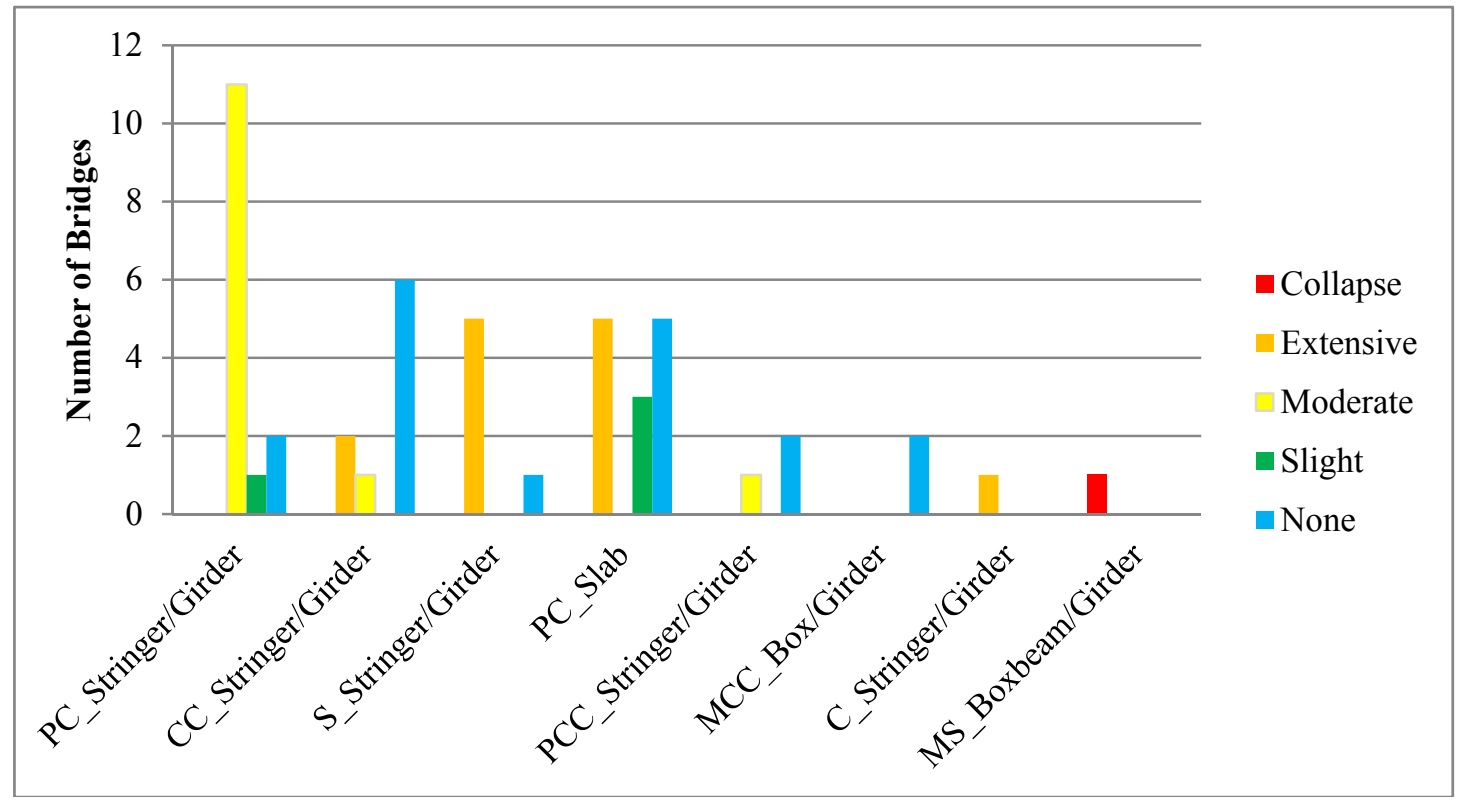

Figure C. 33: Cascadia M9.0 Scenario on OR 42.

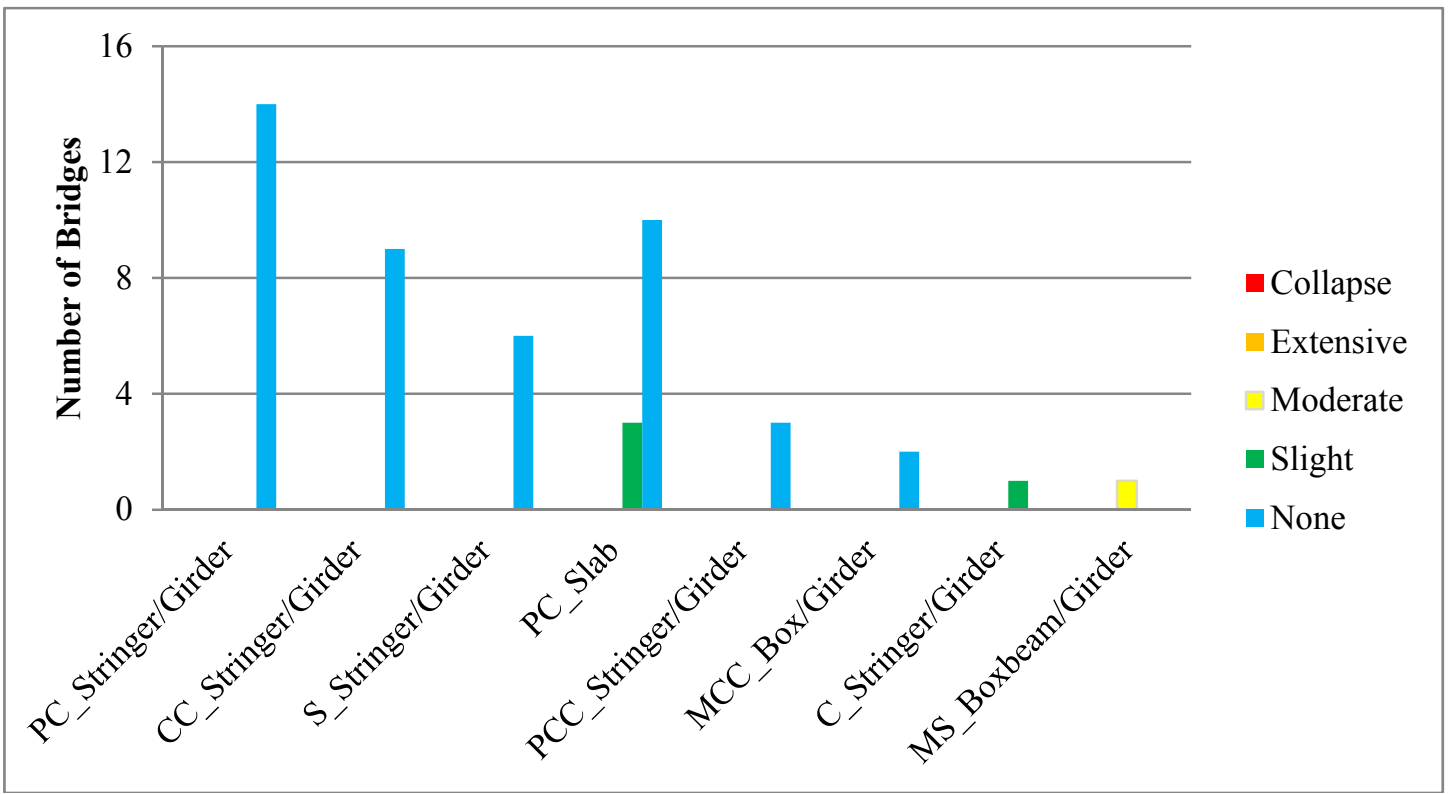

Figure C. 34: Cascadia North M8.3 Scenario on OR 42. 


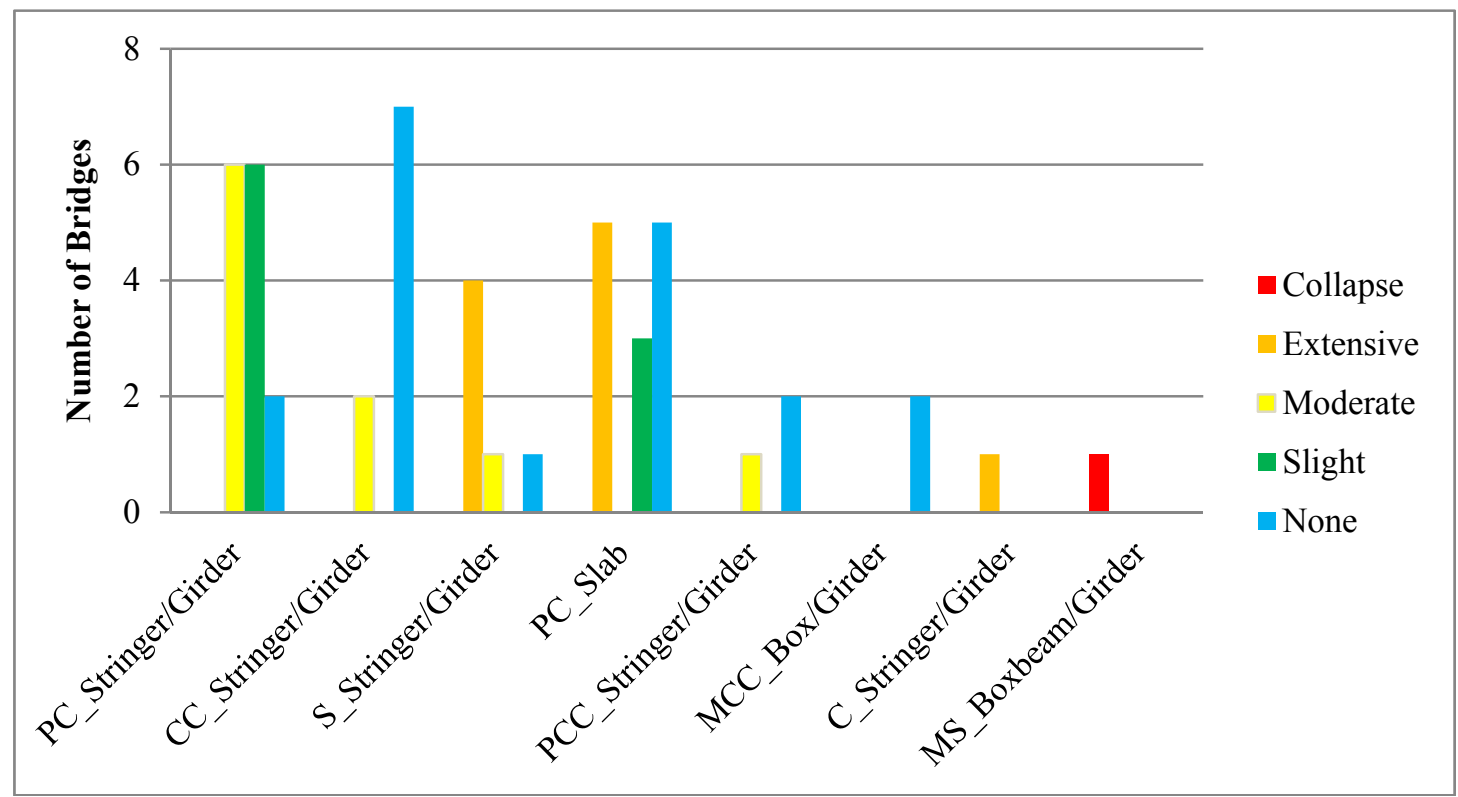

Figure C. 35: Cascadia South M8.3 Scenario on OR 42. 


\subsection{APPENDIX D - BRIDGE CLASSIFICATION BY MATERIAL AND DESIGN PER ROUTE}

Table D. 1: Bridge Classification by Material and Design per Route.

\begin{tabular}{|c|c|c|c|c|c|c|c|c|c|c|c|c|}
\hline Material and Design & I-5 MWC & $\begin{array}{c}\text { I-5 } \\
\text { MLL } \\
\end{array}$ & $\begin{array}{l}\text { I-5 } \\
\text { DJJ } \\
\end{array}$ & $\begin{array}{c}\text { I } \\
84\end{array}$ & $\begin{array}{l}\text { US } \\
101 \\
\end{array}$ & $\begin{array}{l}\text { US } \\
26 \\
\end{array}$ & $\begin{array}{c}I \\
205\end{array}$ & $\begin{array}{c}I \\
405 \\
\end{array}$ & $\begin{array}{l}\text { US } \\
\mathbf{3 0} \\
\end{array}$ & $\begin{array}{l}\text { US } \\
20 \\
\end{array}$ & $\begin{array}{l}\text { OR } \\
38 \\
\end{array}$ & $\begin{array}{c}\text { OR } \\
42 \\
\end{array}$ \\
\hline $\begin{array}{l}\text { Concrete continuous } \\
\text { Stringer/Multi-beam or } \\
\text { Girder }\end{array}$ & 9 & 113 & 66 & 34 & 42 & 15 & 0 & 1 & 9 & 6 & 4 & 9 \\
\hline $\begin{array}{l}\text { Prestressed Concrete } \\
\text { Stringer/Multi-beam or } \\
\text { Girder }\end{array}$ & 6 & 17 & 39 & 34 & 11 & 7 & 9 & 1 & 5 & 11 & 5 & 14 \\
\hline $\begin{array}{l}\text { Concrete Continuous } \\
\text { Box Beam or Girders - } \\
\text { Multiple }\end{array}$ & 23 & 4 & 14 & 21 & 6 & 5 & 13 & 23 & 3 & 0 & 2 & 2 \\
\hline $\begin{array}{l}\text { Concrete Continuous } \\
\text { Slab }\end{array}$ & 2 & 32 & 13 & 17 & 6 & 1 & 0 & 0 & 4 & 0 & 0 & 1 \\
\hline $\begin{array}{l}\text { Prestressed Concrete } \\
\text { Continuous Box Beam or } \\
\text { Girders - Multiple }\end{array}$ & 13 & 13 & 3 & 7 & 3 & 1 & 29 & 1 & 2 & 0 & 0 & 0 \\
\hline $\begin{array}{l}\text { Steel Stringer/Multi- } \\
\text { beam or Girder }\end{array}$ & 22 & 4 & 5 & 10 & 3 & 2 & 3 & 10 & 0 & 1 & 0 & 6 \\
\hline $\begin{array}{l}\text { Prestressed Concrete } \\
\text { Slab }\end{array}$ & 1 & 2 & 8 & 7 & 17 & 3 & 0 & 0 & 6 & 1 & 1 & 13 \\
\hline $\begin{array}{l}\text { Prestressed Concrete } \\
\text { Continuous } \\
\text { Stringer/Multi-beam or } \\
\text { Girder }\end{array}$ & 2 & 15 & 5 & 4 & 4 & 10 & 2 & 0 & 2 & 0 & 0 & 3 \\
\hline $\begin{array}{l}\text { Prestressed Concrete } \\
\text { Box Beam or Girders - } \\
\text { Multiple }\end{array}$ & 2 & 6 & 2 & 8 & 5 & 5 & 9 & 0 & 1 & 0 & 0 & 1 \\
\hline $\begin{array}{l}\text { Steel Continuous } \\
\text { Stringer/Multi-beam or } \\
\text { Girder }\end{array}$ & 2 & 1 & 3 & 27 & 2 & 2 & 1 & 1 & 0 & 0 & 0 & 0 \\
\hline $\begin{array}{l}\text { Concrete Stringer/Multi- } \\
\text { beam or Girder }\end{array}$ & 1 & 1 & 0 & 0 & 20 & 1 & 0 & 0 & 1 & 5 & 0 & 1 \\
\hline Concrete Slab & 0 & 1 & 3 & 6 & 10 & 1 & 2 & 0 & 1 & 0 & 0 & 1 \\
\hline Steel Truss - Deck & 3 & 1 & 7 & 3 & 3 & 2 & 0 & 0 & 0 & 4 & 0 & 1 \\
\hline $\begin{array}{l}\text { Concrete Frame (except } \\
\text { frame culverts) }\end{array}$ & 1 & 1 & 0 & 3 & 1 & 7 & 4 & 5 & 1 & 0 & 0 & 0 \\
\hline $\begin{array}{l}\text { Steel Continuous Box } \\
\text { Beam or Girders - } \\
\text { Multiple }\end{array}$ & 2 & 0 & 0 & 0 & 0 & 0 & 5 & 14 & 0 & 0 & 0 & 0 \\
\hline $\begin{array}{l}\text { Concrete Continuous } \\
\text { Truss - Deck }\end{array}$ & 0 & 2 & 6 & 4 & 0 & 4 & 1 & 0 & 0 & 0 & 0 & 0 \\
\hline Material and Design & I-5 MWC & $\begin{array}{c}\text { I-5 } \\
\text { MLL }\end{array}$ & $\begin{array}{l}\text { I-5 } \\
\text { DJJ }\end{array}$ & $\begin{array}{c} \\
84 \\
\end{array}$ & $\begin{array}{c}\text { US } \\
101 \\
\end{array}$ & $\begin{array}{l}\text { US } \\
26\end{array}$ & $\begin{array}{c} \\
205 \\
\end{array}$ & $\begin{array}{c} \\
405 \\
\end{array}$ & $\begin{array}{l}\text { US } \\
30 \\
\end{array}$ & $\begin{array}{l}\text { US } \\
20 \\
\end{array}$ & $\begin{array}{l}\text { OR } \\
38 \\
\end{array}$ & $\begin{array}{l}\text { OR } \\
42 \\
\end{array}$ \\
\hline Concrete Truss - Deck & 0 & 4 & 3 & 1 & 1 & 3 & 0 & 0 & 0 & 2 & 2 & 0 \\
\hline Steel Continuous Frame & 6 & 0 & 0 & 4 & 1 & 0 & 0 & 0 & 0 & 0 & 0 & 0 \\
\hline
\end{tabular}




\begin{tabular}{|c|c|c|c|c|c|c|c|c|c|c|c|c|}
\hline (except frame culverts) & & & & & & & & & & & & \\
\hline $\begin{array}{l}\text { Prestressed Concrete } \\
\text { Continuous Box Beam or } \\
\text { Girders - Single or } \\
\text { Spread }\end{array}$ & 1 & 2 & 0 & 0 & 1 & 0 & 3 & 0 & 0 & 0 & 0 & 0 \\
\hline Steel Truss - Thru & 0 & 0 & 1 & 1 & 2 & 0 & 0 & 0 & 0 & 2 & 0 & 0 \\
\hline $\begin{array}{l}\text { Steel Continuous Girder } \\
\text { and Floor beam System }\end{array}$ & 0 & 0 & 2 & 3 & 0 & 0 & 0 & 0 & 0 & 0 & 0 & 0 \\
\hline $\begin{array}{l}\text { Steel Girder and Floor } \\
\text { beam System }\end{array}$ & 1 & 0 & 0 & 2 & 0 & 0 & 0 & 0 & 2 & 0 & 0 & 0 \\
\hline $\begin{array}{l}\text { Prestressed Concrete } \\
\text { Continuous Slab }\end{array}$ & 0 & 1 & 1 & 1 & 0 & 0 & 0 & 0 & 0 & 0 & 0 & 1 \\
\hline $\begin{array}{l}\text { Concrete Continuous } \\
\text { Box Beam or Girders - } \\
\text { Single or Spread }\end{array}$ & 0 & 0 & 1 & 0 & 0 & 1 & 1 & 0 & 0 & 0 & 0 & 0 \\
\hline $\begin{array}{l}\text { Prestressed Concrete } \\
\text { Box Beam or Girders - } \\
\text { Single or Spread }\end{array}$ & 0 & 1 & 0 & 1 & 0 & 1 & 0 & 0 & 0 & 0 & 0 & 0 \\
\hline $\begin{array}{l}\text { Steel Box Beam or } \\
\text { Girders - Multiple }\end{array}$ & 0 & 0 & 0 & 0 & 2 & 0 & 0 & 0 & 0 & 0 & 0 & 1 \\
\hline $\begin{array}{l}\text { Steel Continuous Truss - } \\
\text { Deck }\end{array}$ & 0 & 0 & 0 & 0 & 1 & 2 & 0 & 0 & 0 & 0 & 0 & 0 \\
\hline $\begin{array}{l}\text { Steel Continuous Truss - } \\
\text { Thru }\end{array}$ & 0 & 0 & 0 & 0 & 1 & 0 & 0 & 0 & 1 & 0 & 1 & 0 \\
\hline $\begin{array}{l}\text { Prestressed Concrete } \\
\text { Tee Beam }\end{array}$ & 0 & 0 & 1 & 1 & 0 & 0 & 0 & 0 & 0 & 0 & 0 & 0 \\
\hline $\begin{array}{l}\text { Steel Box Beam or } \\
\text { Girders - Single or } \\
\text { Spread }\end{array}$ & 0 & 0 & 0 & 0 & 1 & 1 & 0 & 0 & 0 & 0 & 0 & 0 \\
\hline $\begin{array}{l}\text { Concrete Box Beam or } \\
\text { Girders - Multiple }\end{array}$ & 0 & 0 & 1 & 0 & 0 & 0 & 0 & 0 & 0 & 0 & 0 & 0 \\
\hline $\begin{array}{l}\text { Concrete continuous } \\
\text { Girder and Floor beam } \\
\text { System }\end{array}$ & 0 & 0 & 0 & 0 & 0 & 1 & 0 & 0 & 0 & 0 & 0 & 0 \\
\hline $\begin{array}{l}\text { Concrete Continuous Tee } \\
\text { Beam }\end{array}$ & 0 & 0 & 0 & 0 & 0 & 1 & 0 & 0 & 0 & 0 & 0 & 0 \\
\hline $\begin{array}{l}\text { Prestressed Concrete } \\
\text { Continuous Girder and } \\
\text { Floor beam System }\end{array}$ & 0 & 0 & 0 & 1 & 0 & 0 & 0 & 0 & 0 & 0 & 0 & 0 \\
\hline
\end{tabular}




\subsection{APPENDIX E - SKEW ANGLE INCONSISTENCY}

Table E. 1: Skew angle definition inconsistent with REDARS2.

\begin{tabular}{|c|c|c|}
\hline NBI Ref & Name & $\begin{array}{c}\text { NBI Skew } \\
\text { Angle }\end{array}$ \\
\hline 13514H002 00660 & I-84 (HWY 002) over CONN 1 (HWY 2) at 2.0 MI E OF NE 74TH AVE & 60 \\
\hline 1609807200173 & HWY 72 over CLAGGET CR at $0073 \mathrm{~N}$ OF SALEM CITY L & 78 \\
\hline 0988306400969 & I-205 (HWY 064) over CREEK at $0.4 \mathrm{M}$ E OF 1E INTERCHANGE & 59 \\
\hline 1840800207116 & I-84 (HWY 002) over UPRR at 111 MI W THE DALLES & 59 \\
\hline 0967214300920 & OR 210 (HWY 143) over HWY 144 at 1.5 MI SW BEAVERTON CC & 55 \\
\hline 0970206400951 & I-205 (HWY 064) over MAIN ST at 0.4 MI N OF W. LINN BR & 55 \\
\hline $09718171 \mathrm{C} 00409$ & OR 224 (HWY 171)CO over HWY 64 at 2.9 MI N OF CLACKAMAS RV & 55 \\
\hline 1919904707083 & US 26 (HWY 047) over HWY 29 CANYON RD at 3.7 MI W OF PORTLAND CC & 55 \\
\hline 01205A033 04568 & US 20 (HWY 033) over WPRR \& HARRIS RD at 05.0 MI W OF PHILOMATH & 54 \\
\hline 07794B001 28228 & I-5 (HWY 001) SB over HWY 51 at 020 MI N MARION-CLACK LN & 54 \\
\hline 0783200117475 & I-5 (HWY 001) CON over CENTRAL ORE RR at 005 MI S OF COTTAGE GROVE & 54 \\
\hline 1826816200142 & OR 22 (HWY 162) over I-5 (HWY 001) at INTER.N SANTIAM HWY ANDI5 & 54 \\
\hline 0186803700578 & OR 6 (HWY 037) over WILSON RIVER MILLS BRDG. at 058 MI E OF HWY 9 JCT & 53 \\
\hline 0971706401376 & I-205 (HWY 064) NB over UPRR at 4.6 MI N OF OREGON CITY & 52 \\
\hline 09717A064 01376 & I-205 (HWY 064) SB over UPRR at 4.6 MI N OF OREGON CITY & 52 \\
\hline 07800A001 27469 & BROADACRES RD over I-5 (HWY 001) at 028 MI N ORE 214 & 51 \\
\hline 1354006401743 & I-205 (HWY 064) NB over PEDESTRIAN PATH at 0.8 MI N OF PORTLAND SCL & 51 \\
\hline 13540A064 01743 & I-205 (HWY 064) SB over PEDESTRIAN PATH at 0.8 MI N OF PORTLAND SCL & 51 \\
\hline 1910700108652 & I-5 (HWY 001) SB over COW CREEK at I5 NB MP 86.52 & 51 \\
\hline $0771502 \mathrm{~W} 06082$ & HWY $2 \mathrm{~W}$ over SWEDETOWN COUNTY R at $1.0 \mathrm{MI}$ E CLATSKANIE & 50 \\
\hline 07728A001C29130 & UPPER BOONES FERRY over I-5 (HWY 001) at $1.5 \mathrm{MI} N$ OF TUALATIN RV & 49 \\
\hline 07854C00125910 & I-5 (HWY 001) over UPRR at 003 MI S OF SALEM NCL & 49 \\
\hline 0893906203240 & OR 126 (HWY 062) over CHICHAHOMINY CREEK at 003 MI W WALTON & 49 \\
\hline $18480001 \mathrm{C} 29225$ & HWY 1NB TO HWY 144 over I-5 (HWY 001) at 2.63 MI N OF TUALATIN RV & 49 \\
\hline 0160104503876 & OR 38 (HWY 045) over ELK CR 2ND XING at 029 MI E ELKTON & 48 \\
\hline 0834100105578 & I-5 (HWY 001) over HWY 025 SPUR at 25.3 MI N OF MEDFORD NCL & 48 \\
\hline 0860500204505 & I-84 (HWY 002) EB over HWY 100 at IN CASCADE LOCKS & 48 \\
\hline
\end{tabular}


Table E. 2: No drawing available.

\begin{tabular}{|c|c|c|}
\hline NBI Ref & Name & $\begin{array}{c}\text { NBI Skew } \\
\text { Angle }\end{array}$ \\
\hline 03172A03500414 & OR 42 (HWY 035) over CENTRAL ORE RR at 06.0 MI W COQUILLE & 57 \\
\hline 03849B020 00125 & Murdock Creek, Hwy 19 & 90 \\
\hline 1814227005883 & & 90 \\
\hline 1745902100250 & OR 66 (HWY 021) over NEIL CREEK at 01.2 MI E OF HWY 001 & 79 \\
\hline 00598D244 01678 & OR 42S (HWY 244) over COQUILLE RIVER at 00.5 W JCT HWY 035 & 75 \\
\hline 0736900219762 & US 730 (HWY 002) over UPRR at 5.7 MI W WASHINGTON ST LN & 74 \\
\hline 0711001800808 & OR 58 (HWY 018) over UPRR at 081 MI E HWY 1 JCT & 65 \\
\hline 02625A191 03072 & OR 223 (HWY 191) over MARYS RIVER at 007 MI N WREN & 63 \\
\hline 02020A004 27995 & USRS Canal J, Hwy 426 & 60 \\
\hline 2033700113200 & I-5 (HWY 001) NB over I-5 @ WILBUR-UMPQUA RD - at I-5 (HWY 001) NB & 60 \\
\hline 02474B004 25252 & Link River, Hwy 20 & 58 \\
\hline $07770162 \mathrm{C} 00191$ & LANCASTER over OR 22 (HWY 162) CONN at 012 MI E OF SALEM & 57 \\
\hline 0963500626492 & I-84 (HWY 006) WB over UNION JCT INTCH WB at 3.1 MI. E. JCT. OR 82 & 57 \\
\hline 09635A006 26492 & I-84 (HWY 006) EB over UNION JCT INTCH EB at 3.1 MI. E. JCT. OR 82 & 57 \\
\hline 00406A021 00076 & OR 66 (HWY 021) over CENTRAL ORE RR at 006 MI W HWY I & 56 \\
\hline 1746002100317 & OR 66 (HWY 021) over NEIL CREEK at 01.8 MI E OF HWY 001 & 56 \\
\hline 1878701910927 & Little Deschutes River, Hwy 18 & 56 \\
\hline 0781716204289 & OR 22 (HWY 162) over SLIDE VIADUCT at 069 MI W DETROIT & 55 \\
\hline 1827605000157 & & 55 \\
\hline 0807316200544 & OR 22 (HWY 162) over JOSEPH ST at 036 MI E SALEM & 54 \\
\hline 1918316206642 & OR 22 (HWY 162) over MARION CREEK at IN MARION FORKS & 53 \\
\hline 00776A05204547 & OR 74 (HWY 052) over HINTON CREEK(HEPPNER) at IN HEPPNER & 50 \\
\hline 1742416200890 & OR 22 (HWY 162) WB over BEAVER CREEK at 6.1 MI E SALEM & 50 \\
\hline 2021200113046 & I-5 (HWY 001) SB over I-5 @ CORP \& CO RD at 4.3 MI S OF SUTHERLIN SCL & 50 \\
\hline 47041500000000 & 13TH ST EAST over SHELTON DITCH at PARALLEL TO 470414 & 50 \\
\hline 0214702001839 & Link River \& Hwy 20, Hwy 4 & 49 \\
\hline 0717101803709 & OR 58 (HWY 018) over PRIVATE LOGGING ROAD at 020 MI E OAKRIDGE & 49 \\
\hline 0898103002486 & OR 22 (HWY 030) over OR 221 (HWY 150) CONN at 001 MI E SALEM & 49 \\
\hline 00646A026 09749 & OR 35 (HWY 026) over MHR \& UNNAMED CR at 5.0 MI S HOOD RIVER ECL & 48 \\
\hline $0201001 \mathrm{~W} 00486$ & OR 99W (HWY 001W) over SW MULTNOMAH BLVD at 1.7 MI S OF HWY 40 & 47 \\
\hline 0861430000551 & $\begin{array}{l}\text { OR } 206 \text { (HWY 300) over GRASS VALLEY CANYONCREEK at } 055 \text { MI SE } \\
\text { WASCO }\end{array}$ & 46 \\
\hline 1815300208213 & RIVER RD over I-84 (HWY 002) at WEST THE DALLES & 58 \\
\hline 08232N001 22242 & I-5 (HWY 001) NB over BUTTE CREEK at 191 MI N LANE-LINN LINE & 55 \\
\hline 00860A03301525 & US 20 (HWY 033) over SIMPSON CREEK at 082 MILE E. OF TOLEDO & 50 \\
\hline 09015A00130686 & I-5 (HWY 001) over HWY 1W NB TO HWY 1 NB & 65 \\
\hline
\end{tabular}


Table E. 3: Skew angle definition consistent with REDARS2.

\begin{tabular}{|c|l|c|}
\hline NBI Ref & \multicolumn{1}{|c|}{ Name } & $\begin{array}{c}\text { NBI Skew } \\
\text { Angle }\end{array}$ \\
\hline 0236304704947 & US 26 (HWY 047) over HWY 102 DAVIES/PTB at 4.0 MI W HWY 37 JCT & 60 \\
\hline 0050500906348 & US101(HWY009) over JUNO OXING SPRR at 020 MI N TILLAMOOK & 54 \\
\hline 07794 A001 28225 & I-5 (HWY 001) NB over HWY 51 at 020 MI N MARION-CLACK LN & 54 \\
\hline $07029 A 000000110$ & $\begin{array}{l}\text { NE HALSEY ST over B-21 X I-84/UPRR/LT RAIL at NE 68TH AVE \& NE } \\
\text { HALSEY }\end{array}$ & 53 \\
\hline 1616100124938 & $\begin{array}{l}\text { I-5 (HWY 001) NB over COMMERCIAL STREET at 00.33 M JUNCTION HWY } \\
\text { 1E }\end{array}$ & 52 \\
\hline 07439 A001 25257 & I-5 (HWY 001) SB over MILL CREEK at AT SALEM SCL & 49 \\
\hline 0925506100139 & SW 12TH ST over HWY 61 at 0.2 MI S OF MARKET ST & 48 \\
\hline 13514 C064 02271 & I-205 (HWY 064) over HWY 64 CONN 2 at 3.8 MI S ORE-WASH LINE & 48 \\
\hline 0819800129755 & SW BRIER PLACE over HWY 1 I-5 at 3.9 MI S OF BURNSIDE BR & 47 \\
\hline 0972406400828 & SUNSET AVE over HWY 64 at 0.9 MI S OF WILLAMETTE R & 47 \\
\hline 02173 A035 07602 & OR 42 (HWY 035) over CENTRAL ORE RR at 012 MI NW HWY 1 JCT & 46 \\
\hline 0744200125032 & BATTLE CREEK RD over I-5 (HWY 001) at 013 MI N OF JCT HWY 1E & 46 \\
\hline 0833300105540 & I-5 (HWY 001) over FOOTHILL BLVD at 24.9 MI N OF MEDFORD NCL & 46 \\
\hline 08676 B001C02758 & BARNETTE RD CONN over I-5 (HWY 001) at 1.5 MI N OF MEDFORD SCL & 46 \\
\hline
\end{tabular}





\section{GOTREC \\ AND EDUCATION CONSORTIUM}

P.O. Box 751

Portland, OR 97207

OTREC is dedicated to stimulating and conducting collaborative multi-disciplinary research on multi-modal surface transportation issues, educating a diverse array of current practitioners and future leaders in the transportation field, and encouraging implementation of relevant research results. 